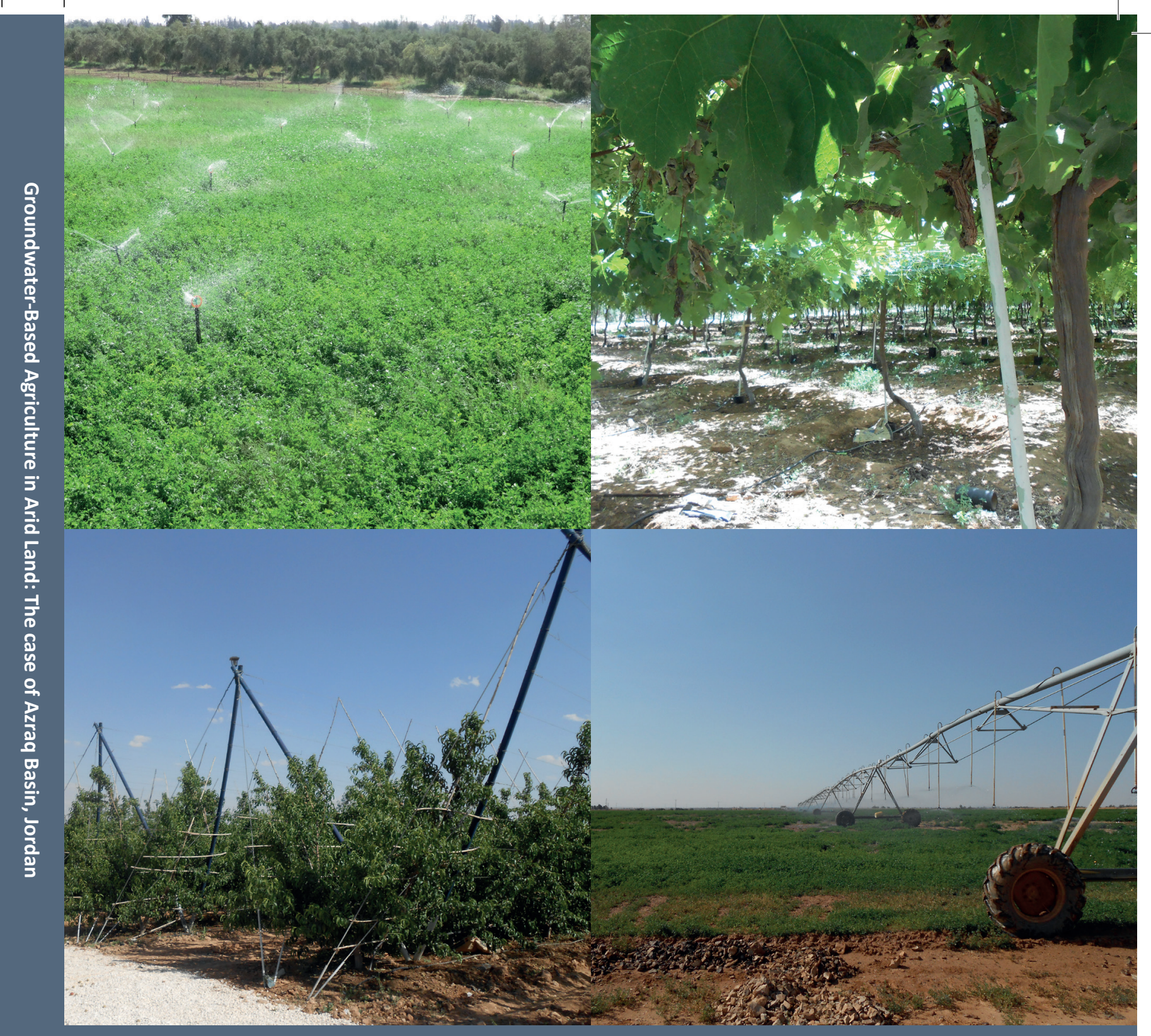

Groundwater-Based Agriculture in Arid Land:

The case of Azraq Basin, Jordan

Majd Al Naber 


\section{Propositions:}

1. Indirect regulatory measures are more efficient than direct measures in controlling the use of groundwater resources.

(this thesis)

2. Decreasing the accessibility to production factors constrains, but does not fully control, groundwater-based agriculture expansion.

(this thesis)

3. Remote sensing technology should be used in daily practice to monitor environmental changes.

4. Irreversible changes are more common than reversible ones in cases of over exploitation of natural resources.

5. A doctorate title is not the achievement of one's life, but a stepping-stone to one's future.

6. Positivity is required to deal with the long Ph.D. journey.

Propositions belonging to the thesis, entitled

Groundwater-Based Agriculture in Arid Land: The Case of Azraq Basin, Jordan

Majd Al Naber

Wageningen, 10 April 2018 


\title{
Groundwater-Based Agriculture in Arid Land: The Case of Azraq Basin, Jordan
}

\author{
Majd Al Naber
}




\section{Thesis committee}

\section{Promotors}

Prof. Dr J. Wallinga

Professor of Soil and Landscape

Wageningen University \& Research

\section{Co-promotor}

Dr F. Molle

Senior Researcher, G-Eau Research Unit

Institut de Recherche pour le Développement, Montpellier, France

Dr Ir J. J. Stoorvogel

Associate Professor, Soil Geography and Landscape

Wageningen University \& Research

\section{Other members}

Prof. Dr Ir P.J.G.J. Hellegers, Wageningen University \& Research

Prof. Dr Olivier Petit, Université d'Artois, France

Prof. Dr Ir P. van der Zaag, IHE Delft University

Dr Ir J. Hoogesteger van Dijk, Wageningen University \& Research

This research was conducted under the auspices of the Doctoral School of Territoires, Temps, Sociétés et Développement, Montpellier, France, and the Graduate School for Production Ecology and Resource Conservation (PE\&RC), The Netherlands, and as part of the joint Erasmus Mundus PhD programme Agricultural Transformation by Innovation (AgTrain). 


\title{
Groundwater-Based Agriculture in Arid Land: The Case of Azraq Basin, Jordan
}

\author{
Majd Al Naber
}

Thesis

submitted in fulfilment of the requirements for the joint degree of doctor between

Montpellier SupAgro

by the authority of the Directrice Générale,

Dr A.L. Wack, and

Wageningen University

by the authority of the Rector Magnificus, Prof. Dr. A.P.J. Mol, in the presence of the Thesis Committee appointed by the Academic Boards of both universities

to be defended in public

on Tuesday 10 April 2018

at 11 a.m. in the Aula of Wageningen University 
Majd Al Naber

Groundwater-Based Agriculture in Arid Land: The case of Azraq Basin, Jordan 208 pages.

Joint PhD thesis, Montpellier SupAgro, France, and Wageningen University, Wageningen, The Netherlands (2018)

With references and with summary in English

ISBN: 978-94-6343-739-4

DOI: https://doi.org/10-18174/431556 


\section{Dectication}

for their endless support and unconditional love, \& decticate this thesis to me famile.

To my one and only mankind, who is always there to suppont me in time of need, to my backbone, to my father

To min safe place, who is alwayes there to lighten my way with her kindness and love, to me fallen angel, to my mother.

To my support sestem, those who were always by my side to share happiness and hard times, to me brothers and me sister

\section{East but not least,}

To my friends, thank pou for pour endless encouragements throughout the pears in moments of jog and onisis 



\section{Acknowledgements}

The research reported in this thesis was carried out in the framework of the Agricultural Transformation by Innovation Erasmus Mundus Joint Doctorate Program (AGTRAIN; www.agtrain.eu), funded by the EACEA (Education, Audiovisual and Culture Executive Agency) of the European Commission. My sincere thanks go to the coordinators of the AGTRAIN program, Dr. Andreas de Neergaard, Dr. Didier Pillot and Dr. Theo Jetten for their endless support and to Mrs. Ida Marie Krogager, Mrs. Corinne Pickett and Mrs. Mieke Hannink, for their administrative support.

I would like to express my special gratitude to my supervisors Dr. François Molle and Dr. Jetse Stoorvogel whom encouraged me throughout this research and enriched my career as a scientist and a researcher. François, without your continuous support and cooperation since the beginning I would not have had the opportunity to realize the thesis. Your enthusiasm, time, effort, scientific advice and profound understanding throughout the years gave me the strength to survive during the Ph.D. years and complete having this research. Jetse, thank you very much for the scientific discussions and for your valuable comments, your patience and guidance until the day of finalizing the thesis.

I must express my cordial thanks and gratitude to Eng. Emad Al Khalil for guiding me in the fieldwork visits. Emad, without your nonstop support and indispensable collaboration, data collection would not have been possibly achieved.

My gratitude goes to farmers and locals of Azraq and Mafraq and to all people who were interviewed. Your cooperation has been much appreciated as it was highly valuable for my research.

Thanks should be addressed to the USAID/IWMI team which conducted the project "groundwater governance in the Arab world" to which this research contributed: Dr. Alvar, Dr. Amer, Dr. François, Dr. Ammar, Dr. Emad, Dr. Khair, Dr. Ousama, Eng. Ali and Eng. Emad, working with you added a positive value to my research scientifically and morally.

I must express my gratitude to my father, mother, brothers and sister for their continued moral support and encouragements. I was continually amazed by their patience while experiencing all the ups and downs of my research.

Completing this work would have been difficult without my friends' support and I am really indebted to them for their help. 



\section{Acronyms and terms}

\begin{tabular}{|c|c|}
\hline ABHSM & Agence du Bassin Hydraulique du Souss Massa \\
\hline ADA & Agence pour le Développement Agricole, Morocco \\
\hline Amlak al-dawla & Land owned by the state \\
\hline APEFEL & $\begin{array}{l}\text { Association Marocaine des Producteurs et Exportateurs de Fruits et } \\
\text { Légumes }\end{array}$ \\
\hline BGR & Bundesanstalt für Geowissenschaften und Rohstoffe \\
\hline $\mathrm{Bm}^{3}$ & Billion cubic meters \\
\hline CRDA & Regional Commissions for Agricultural Development, Tunisia \\
\hline Desert agriculture & $\begin{array}{l}\text { Groundwater-based agriculture developed in steppe (Badia) or desert } \\
\text { (Sahra) regions where rainfed agriculture is impossible }\end{array}$ \\
\hline DLS & Department of Land and Survey, Jordan \\
\hline DLU & Department of Land Use, Jordan \\
\hline Dos & Department of Statistics, Jordan \\
\hline Dunum & 0.1 hectare \\
\hline ESCWA & Economic and Social Commission for Western Asia \\
\hline ET & Evapotranspiration \\
\hline FAO & Food and Agriculture Organization \\
\hline Feddan & 4.2 dunum \\
\hline Fils & $0.001 \mathrm{JD}$ \\
\hline GDA & Groupement de Développement Agricole \\
\hline GIZ & Deutsche Gesellschaft für Internationale Zusammenarbeit \\
\hline Hawd & Portion of land with an area of no less than $250 \mathrm{du}$ \\
\hline HCST & Higher Council for Science and Technology, Jordan \\
\hline Hijjeh & $\begin{array}{l}\text { Unofficial land deed, a land sell/buy by a paper written between two } \\
\text { people and signed by two witnesses }\end{array}$ \\
\hline IGRAC & International Groundwater Resources Assessment Centre \\
\hline ljaza & Permit \\
\hline Iqtaa & Islamic practice of tax farming \\
\hline IUCN & International Union for Conservation of Nature \\
\hline$J \mathrm{D}$ & Jordanian Dinar, (1.41 US\$) \\
\hline JMD & Jordan Metrology Department \\
\hline Kharaj land & Land left in the hands of the original non-Muslim owners \\
\hline Khuwwa & Money paid for protection reason \\
\hline Kushan & Official land deed, authorized by the DLS \\
\hline L.L $/ \mathrm{m}^{3}$ & Lebanese lira per cubic meter \\
\hline L.L/yr & Lebanese lira per year \\
\hline MAAR & Ministry of Agriculture and Agrarian Reform, Syria \\
\hline Mahlul land & $\begin{array}{l}\text { Miri agricultural land that had reverted to the crown because the } \\
\text { owner had died without an heir or the land was not cultivated for } \\
\text { three years or more }\end{array}$ \\
\hline Makrama Malikiya & $\begin{array}{l}\text { Royal gift; distribution of land from state treasury, through a grant } \\
\text { from his majesty the king through the Royal Court }\end{array}$ \\
\hline MALI & Ministry of Agriculture and Land Reform, Egypt \\
\hline
\end{tabular}


MAPM

Matrūka land

Mawat land

MENA

MEW

MEWA

$\mathrm{mg} / \mathrm{L}$

Milk land

Miri land

$\mathrm{Mm}^{3}$

$\mathrm{m} / \mathrm{yr}$

$\mathrm{mm} / \mathrm{yr}$

MoA

MWI

MWRI

NGWA

NWRA

OECD

PNEEI

RIGW

RSCN

Rukhsa

Sheikhs

Simsar

Tafwid

Tapu

Taswiye

TJT

UNDP

UNEP

UNESCO

USAID

Ushuri land

Wadaa el yad

WAJ

Wajihat

Waqf land

WWDR
Ministère de l'Agriculture et de la Pêche Maritime, Morocco

Land abandoned without cultivation or ostensible owner such as

roads, market places, and even common pasture between villages

Dead lands, uncultivated and unappropriated, vacant lands such as mountains rocky places, stony fields, and grazing ground which is not in possession of anyone by title deed

Middle East and North Africa

Ministry of Energy and Water, Bahrain

Ministry of Water and Agriculture, Saudi Arabia

Milligram per liter

Land that is privately owned

Land under the custody of the prince

Million cubic meters

Meter per year

Millimeter per year

Ministry of Agriculture

Ministry of Water and Irrigation, Jordan

Ministry of Water Resources and Irrigation, Egypt

National Groundwater Association

National Water Resources Authority, Yemen

Organization Economic Co-operation and Development

Plan National d'Economie d'Eau en Irrigation

Research Institute for Groundwater, Egypt

Royal Society for the Conservation of Nature, Jordan

Licenses

Influential person in the tribe, normally the tribe leader

Brooker

Delegation; a process were people, private or public companies can rent state land for a period of time from the government in order to build, cultivate or make a project on it

Fees paid to register the land

Settlement; a process were a group of potential land owner can ask to legalize their land

The Jordan Time

United Nations Development Programme

United Nations Environment Programme

United Nations Educational, Scientific and Cultural Organization

United States Agency for International Development

Land given into the possession and distributed among the (Muslim)

conquerors at the time of the conquest.

Claiming land illegally

Water Authority of Jordan

Traditional tribes' right

Lands possessed in mortmain or endowment

World Water Development Report 


\section{Summary}

With limitations in the availability and accessibility of surface water, attention is increasingly directed towards groundwater resources as the most reliable source of fresh water for different sectors. Accordingly, groundwater is over abstracted in many countries of the world. The overexploitation of groundwater renewable and non-renewable aquifers for both urban use and irrigation results in a drop of the water table and, frequently, in a reduction in groundwater quality. This study focuses on the use of groundwater for irrigation purposes in desert areas of the MENA region. The objective of this thesis is to contribute to conserving and sustaining the use of limited groundwater resources in desert agriculture, by analyzing the current unsustainable use of groundwater, focusing on groundwater policy on the one hand, and on the specificities of desert agriculture on the other, with a focus on Azraq basin in Jordan.

This study consists of eight chapters, starting with an introduction, six core chapters, and ending with a synthesis chapter. The introduction chapter reviews the general context of the thesis, while chapter two briefly reviews the general features of groundwater-based agriculture in the MENA region and explores the management and policy options available to regulate this sector. We then document 'desert agriculture' in selected countries of the MENA region, examining in particular how farms access the key production factors of land, water, labor, capital. The physical and historical context of Azraq basin, our case study area, is then outlined in chapter three. Chapter four explores the Azraq Basin using spatial analysis GIS tools and all available data, providing a wider view of the windows of intervention for groundwater resource use and management. Chapter five, six and seven emphasizes the driving forces behind the development of desert agriculture in the Azraq basin: Chapter five focuses on the issues of land tenure in historical and present contexts, as access to land is as one of the prime factors fueling desert agriculture, either for profit or land speculation or both. Chapter six deals with water, another key production factor of farming in Azraq basin, and discusses policy measures and tools deployed to regulate use of this resource, law enforcement, and how farmers have responded to these policy and regulatory measures. The chapter then documents how, in response, the Ministry of Water and Irrigation has recently enacted a series of creative counter-measures, both direct and indirect, in an attempt to toughen law enforcement. Chapter seven is based on the results of farm surveys carried out in the two main agricultural areas of the Azraq basin (Azraq and Mafraq). The chapter outlines farm typologies, calculates the level of farm profitability, and discusses the availability and relative costs of production factors (land, water, energy, labor, inputs) in desert areas, as well as the constraints and challenges currently faced by farmers and future prospects. The final chapter of this thesis builds upon the research findings to answer the proposed research questions and zooms out to the MENA region to put the lessons learned in comparative perspective. 



\section{Table of contents}

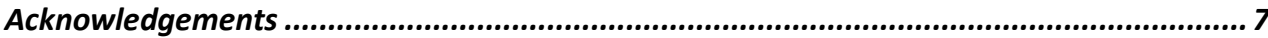

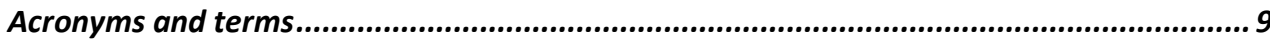

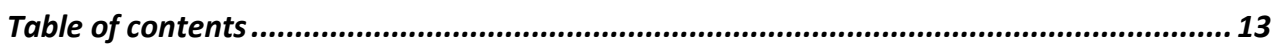

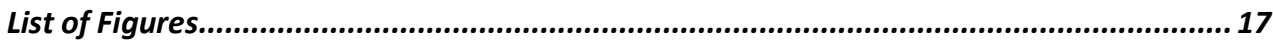

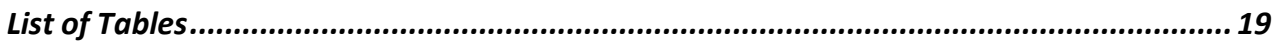

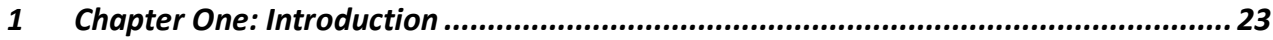

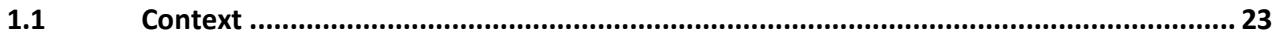

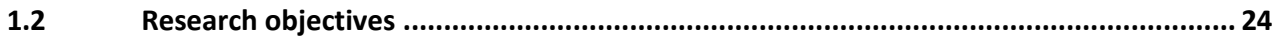

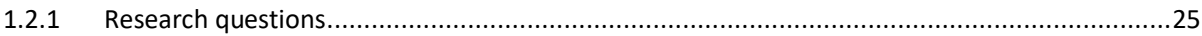

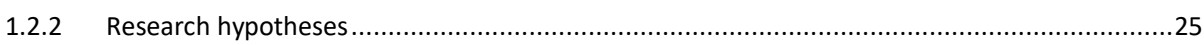

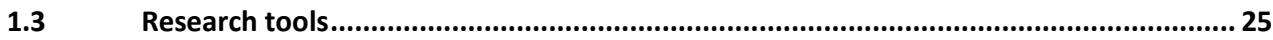

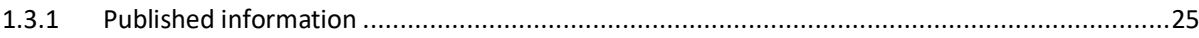

1.3.2 Semi-structured questionnaires of key-informants and conferences ......................................26

1.3.3 Structured questionnaires of a sample of farmers in Azraq.......................................................26

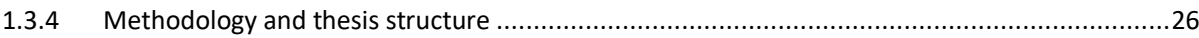

2 Chapter Two: Groundwater Management and Desert Agriculture in the Middle East

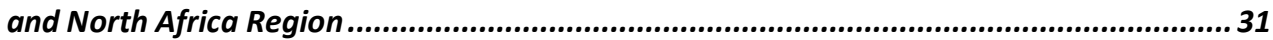

2.1 Groundwater resources in Mena region: usage and management................................... 31

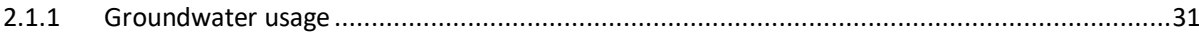

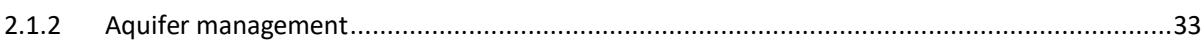

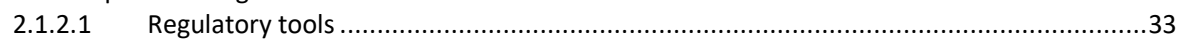

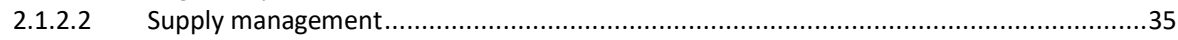

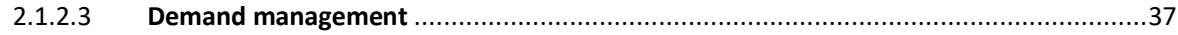

2.1.2.4 Community-based management and co-management ............................................39

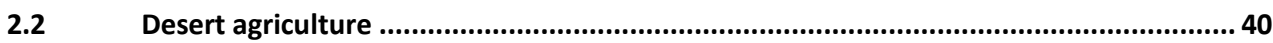

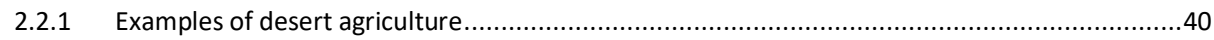

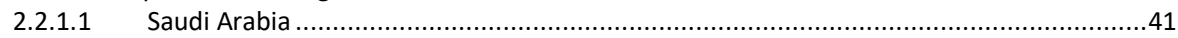

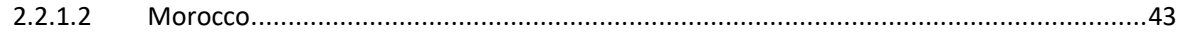

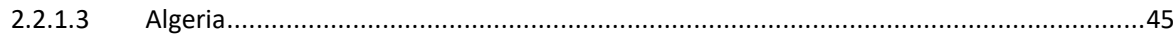

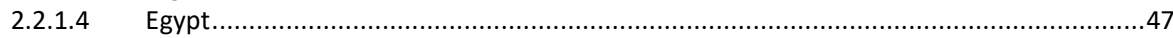

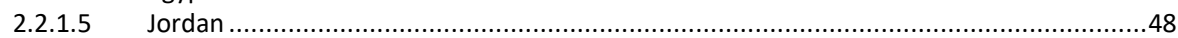




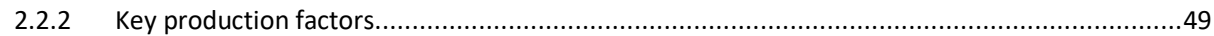

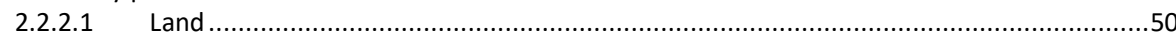

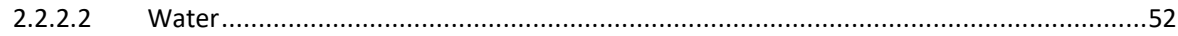

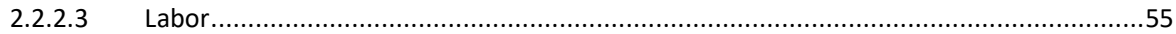

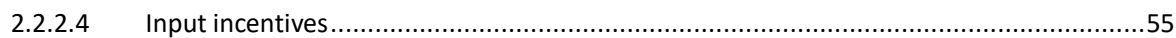

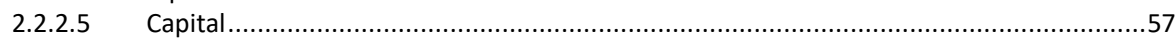

3 Chapter Three: Case Study Description: Azraq Basin, Jordan...................................61

Case study description: Azraq basin ......................................................................61

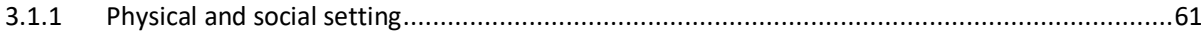

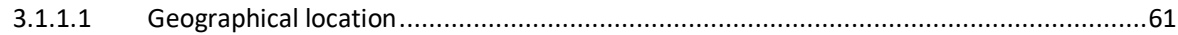

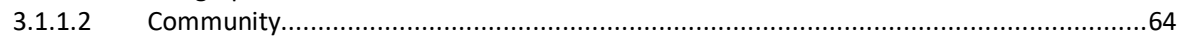

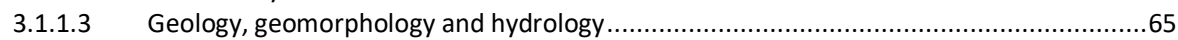

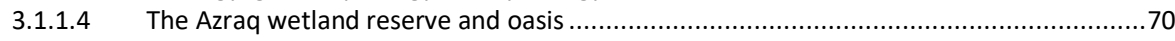

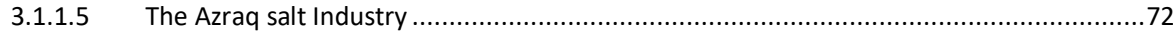

3.1.2 Agriculture development and the use of groundwater ..................................................74

3.1.2.1 Agriculture and groundwater use in Azraq ............................................................ 74

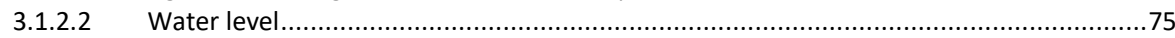

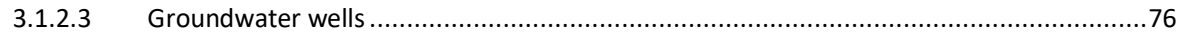

\section{Chapter Four: Explorative Spatial Analyses to Support Stakeholder Deliberation on} Groundwater Management .................................................................................................... 83

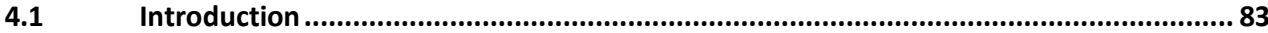

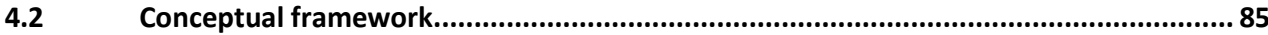

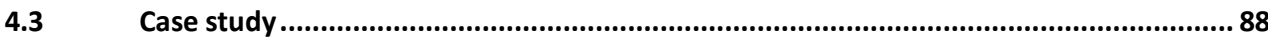

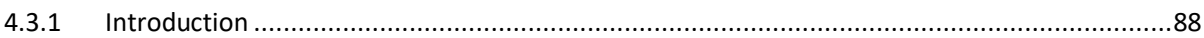

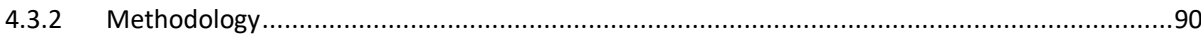

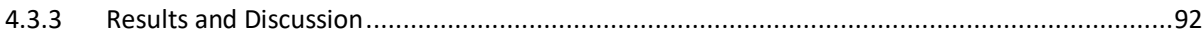

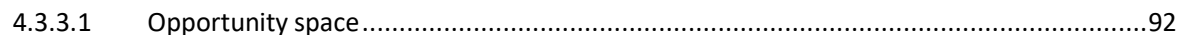

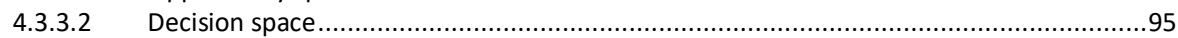

4.3.3.3 Window of opportunity; discussion on potential solutions ........................................96

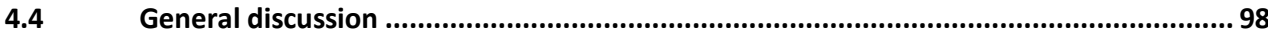

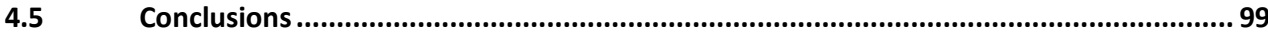

5 Chapter Five: The Politics of Accessing Desert Land in Jordan .......................... 103

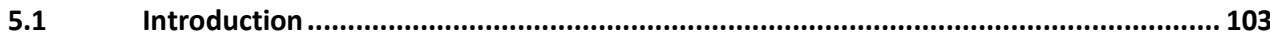

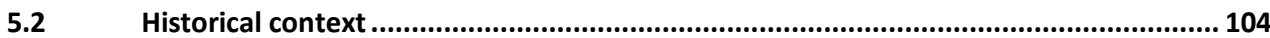

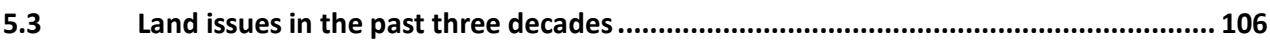

5.3.1 Transfer mechanisms of state land to private use or property .......................................107

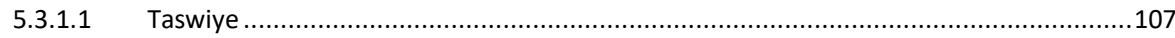

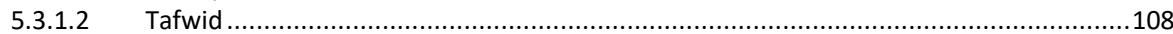

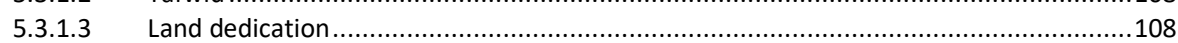

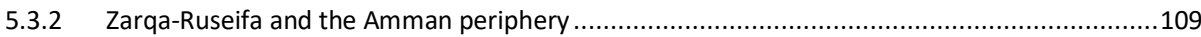

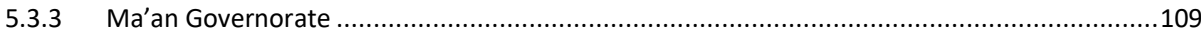

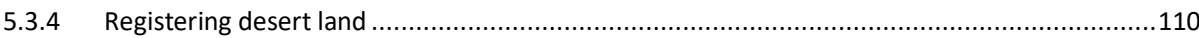


5.4 Desert rights: the case of Azraq Basin 111

5.4.1 Setting. 111

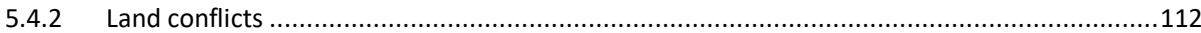

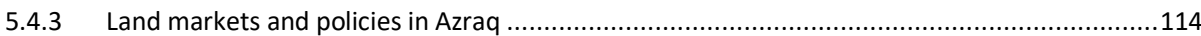

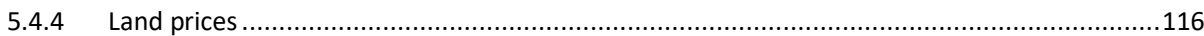

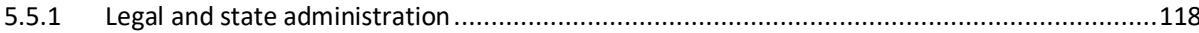

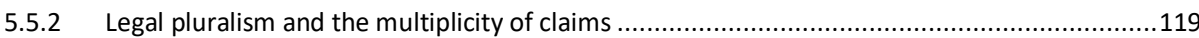

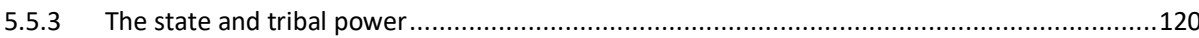

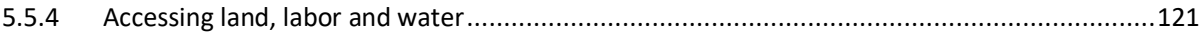

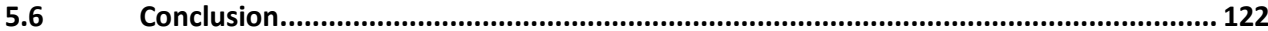

\section{Chapter Six: Controlling Groundwater over Abstraction: State Policies vs. Local}

Practices in Jordan Highlands ...................................................................... 127

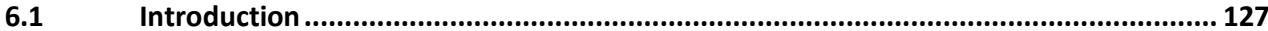

Key steps of groundwater policy in Jordan.......................................................... 129

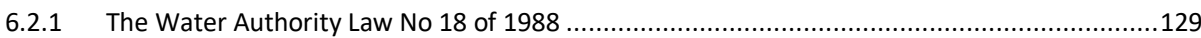

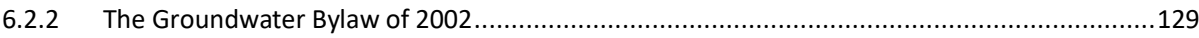

6.2.3 Amendments to the 2002 Groundwater Bylaw and Law No 18 of 1988 ............................131

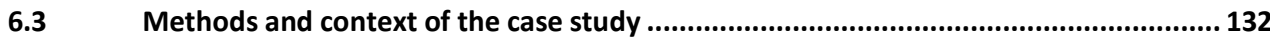

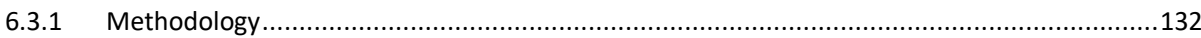

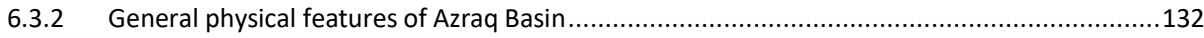

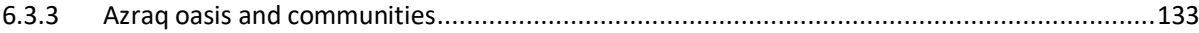

6.3.4 Agriculture and the water situation in Azraq basin ........................................................ 133

6.4 Policies in action: local practices in the Azraq Basin ............................................. 134

6.4.1 Farmer tactics to circumvent regulations ...................................................................134

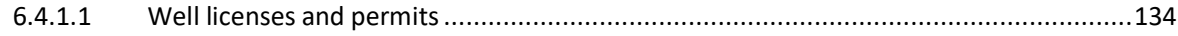

6.4.1.2 Well maintenance (cleaning, replacement and deepening) ........................................135

6.4.1.3 Metering systems .......................................................................................... 135

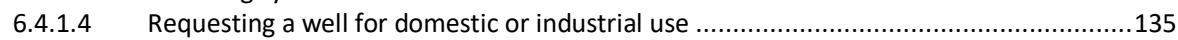

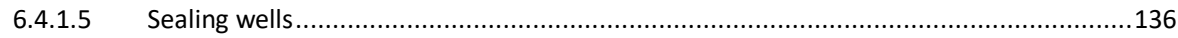

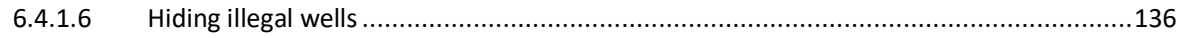

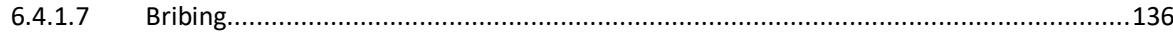

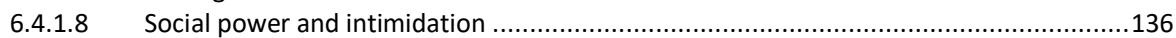

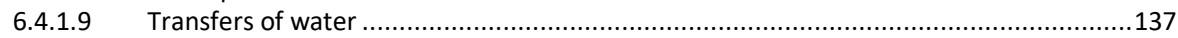

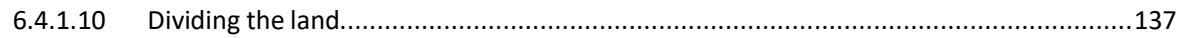

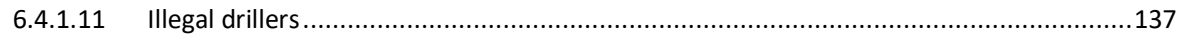

6.4.2 Policy responses by the government ........................................................................... 137

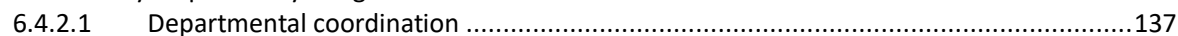

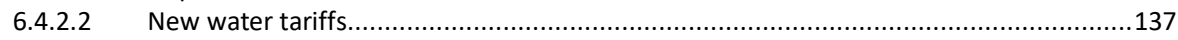

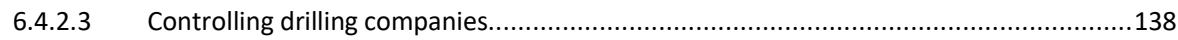

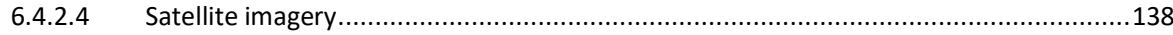

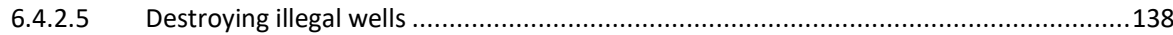

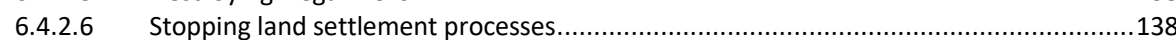


6.4.2.7 Naming and blaming ..................................................................................... 139

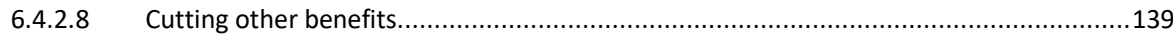

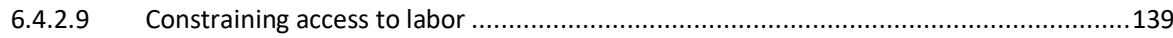

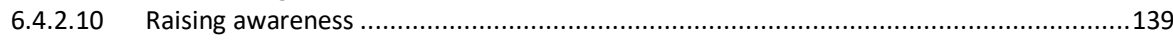

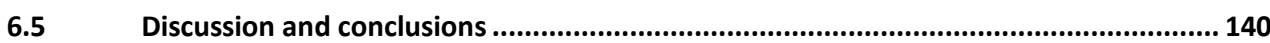

7 Chapter Seven: Water and Sand: is Groundwater-based Farming in Jordan's Desert

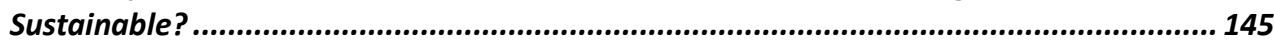

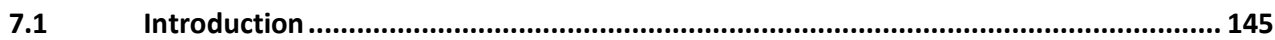

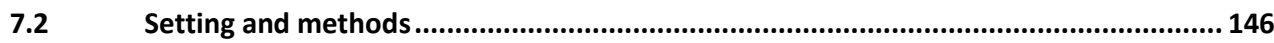

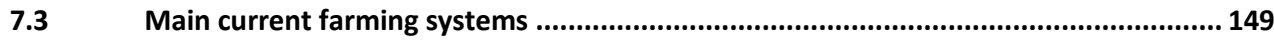

7.3.1 Cropping patterns and cultivated area ................................................................... 149

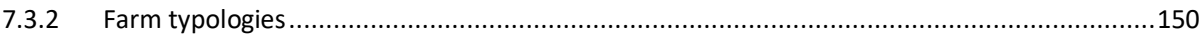

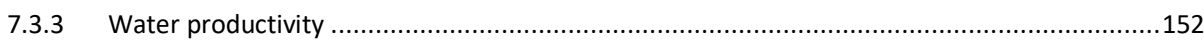

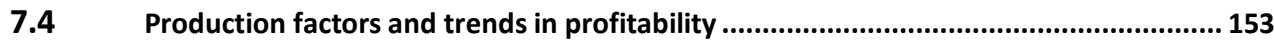

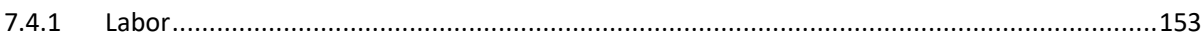

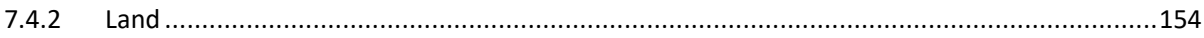

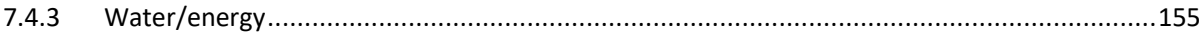

7.4.4 Trends in production costs and profitability .................................................................. 157

7.5 Discussion: the future of agriculture in Azraq .................................................. 158

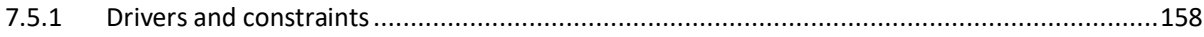

7.5.2 Water pricing and other groundwater policy measures ............................................159

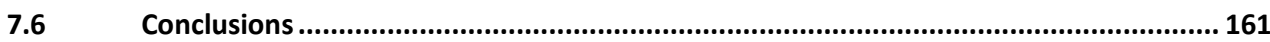

8 Chapter Eight: Synthesis ...................................................................... 165

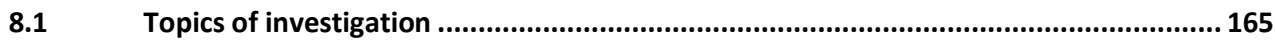

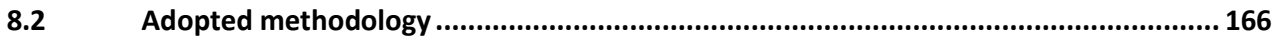

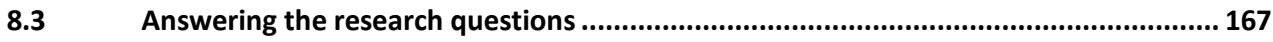

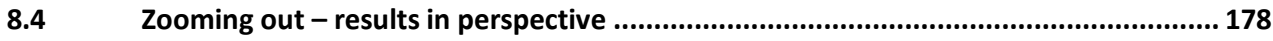

8.5 Implications for the conservation and sustainable use of groundwater.................... 182

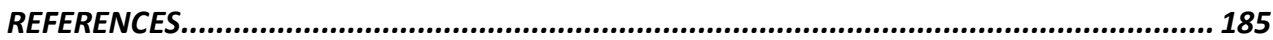

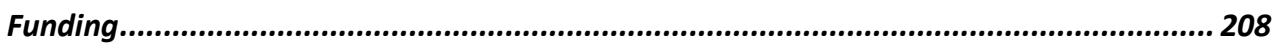




\section{List of Figures}

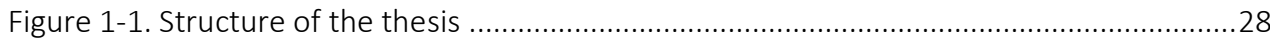

Figure 2-1. Main groundwater policy objectives and tools (Molle and Closas, 2017) ..............34

Figure 2-2. Groundwater aquifers in Saudi Arabia (arabgeographers.net) .............................41

Figure 2-3. Cultivation in Tabuk area (Google Earth and Ministry of Agriculture and Water,

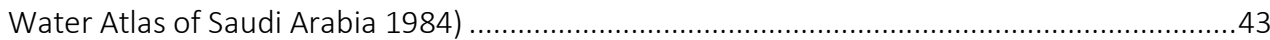

Figure 2-4. Souss Masa aquifer, Morroco (ABHSM, 2005) ......................................................44

Figure 2-5. El Guerdane project scheme (Houdret, 2012) .......................................................45

Figure 2-6. Potato fields in El Ouda (Steinmetz, 2015) .........................................................46

Figure 2-7. Cultivation in Toshka, Egypt (Google Earth) ........................................................48

Figure 2-8. Cultivation in Wadi Rum operates by farmers small cooperatives and big farms companies (Photo credit; Andreas Renck, 2009). ..................................................................49

Figure 3-1. Groundwater basins in Jordan (Royal Jordan Geographic Center, modified by the

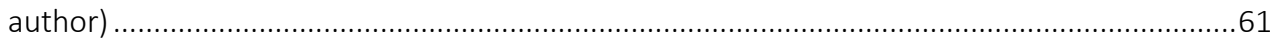

Figure 3-2. Surface water basins in Jordan with study area location (Royal Jordan Geographic

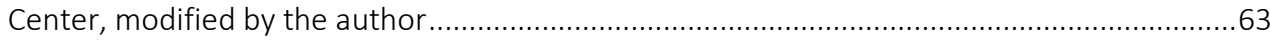

Figure 3-3. Azraq district areas (Google Earth, modified by the author) ................................63

Figure 3-4. Bedouin tribes areas (bin Muhammad, 1999) ....................................................65

Figure 3-5. Aquifer distribution in Azraq basin (Jasem and Al Raggad, 2010) ...........................66

Figure 3-6. Topography of Azraq basin (MWI, 2010; Al Raggad, 2015) ..................................67

Figure 3-7. Estimated withdrawal from groundwater wells and spring discharge $\left(\mathrm{Mm}^{3} / \mathrm{yr}\right)$

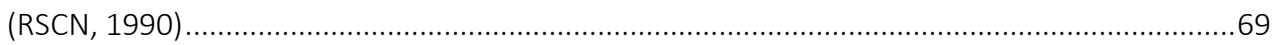

Figure 3-8. Wadis and streams in Azraq basin (Nelson, 1973) .............................................. 70

Figure 3-9. Azraq wetland reserve (RSCN, 2017) ........................................................... 71

Figure 3-10. Artificial recharge into Azraq Wetland Reserve ( $\mathrm{m}^{3} / \mathrm{yr}$ ) (RSCN, 2013) ................72

Figure 3-11. Azraq surface and groundwater basin and Malahat area (Google Earth).............73

Figure 3-12. Salt production in Azraq (Azraq wetland Facebook page) ................................... 74

Figure 3-13. Evolution of the cultivated area in Azraq (in dunum) (MoA, 2012) ......................75

Figure 3-14. Decrease in water table data in monitoring AWSA well (MWI, 2013) ..................76

Figure 3-15. Legal wells in Azraq (Google Earth and raw data from MWI, 2010) ....................77

Figure 3-16. Illegal wells in Azraq (Google Earth and raw data from MWI, 2010) ....................77

Figure 3-17. Abstraction from legal and illegal wells in Azraq ( $\left.\mathrm{m}^{3} / \mathrm{yr}\right)(\mathrm{MWI}, 2010) \ldots \ldots \ldots \ldots \ldots . . . .78$

Figure 3-18. Distributions of salinity in Azraq (Google Earth and raw data MWI, 2010) ..........79

Figure 4-1. Percentage of total renewable groundwater resources withdrawn by region (FAO

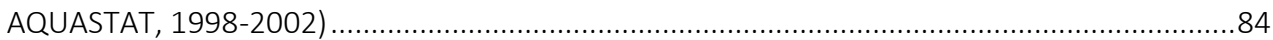

Figure 4-2. Conceptual layout for windows of opportunities ............................................... 87

Figure 4-3. Azraq basin location (left) and the three governorates inside Azraq basin, Jordan

Figure 4-4. Azraq basin contour lines with groundwater flow direction in Azraq basin (left) and groundwater stream flow direction towards Azraq depression (right) ............................89 Figure 4-5. Mean annual temperature in ${ }^{\circ} \mathrm{C}$ (left) and annual precipitation in $\mathrm{mm}$ (right) in Azraq basin .91

Figure 4-6. Elevation map (left), streams link and Azraq depression area with elevation map for Azraq basin (right) 
Figure 4-7. NDVI map for Azraq basin (left) and reflection of agriculture land near Azraq depression using Google earth map (right) ..................................................................92

Figure 4-8. Fluctuation in groundwater table in Awsa field, Azraq (WAJ, 2014) ......................95

Figure 4-9. Window of ideal sustainable feasible solutions ...................................................99

Figure 5-1. Number of transactions in the years 1973-2012 (DLS annual reports; Razzaz, 1992)

107

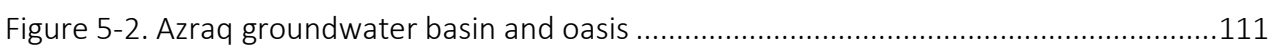

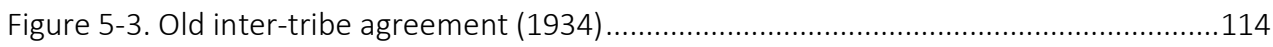

Figure 5-4. Reported prices (JD) of land transaction according to place and time ................117

Figure 6-1. Azraq basin elevation and streams .................................................................133

Figure 7-1. Groundwater and surface water basin in Azraq (adopted from Schmidt et al.,

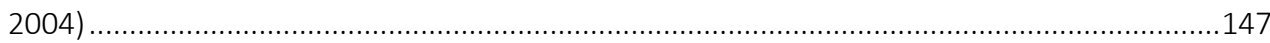

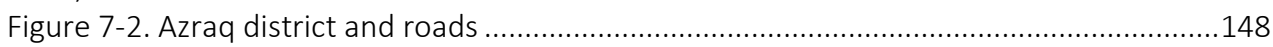

Figure 7-3. Water productivity according to farm typology in Azraq and Mafraq ..................153

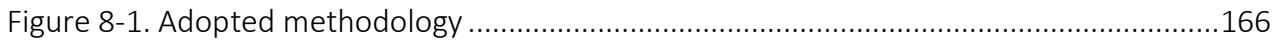

Figure 8-2: Summary of main issues related to each production factor..................................168 


\section{List of Tables}

Table 2-1. Main regulatory tools used in MENA countries (adapted from Closas and Molle,

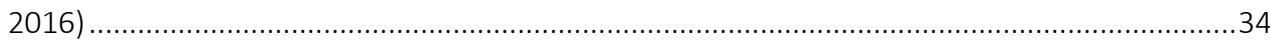

Table 2-2. Incentives for irrigation (World Bank, 2007) .............................................................55

Table 3-1. Groundwater basins usage, safe yield and balance (MWI, 2009; Molle et al., 2017a)

Table 3-2. Estimation of Azraq basin recharge (Noble, 1998; Sharif, 2009; El-Naqa, 2010; Shawaqfeh, 2015) .68

Table 3-3. Estimated withdrawals from groundwater wells with spring discharge (RSCN, 1990)

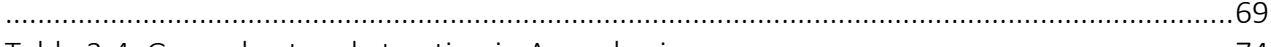

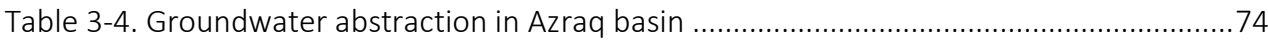

Table 3-5. Prediction of groundwater table decline (Abdulla et al., 1999) ...............................76

Table 4-1. Groundwater usage in Azraq basin from the registered legal wells during 2009

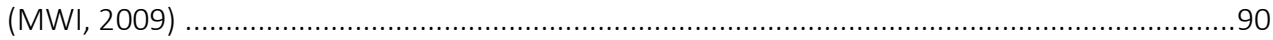

Table 4-2. Irrigation system types and efficiency in Azraq basin..............................................94

Table 4-3. Estimated net crop water requirement for the actual cropping pattern in Azraq

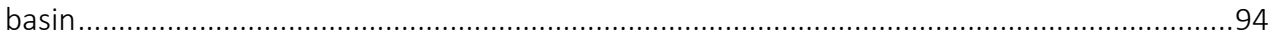

Table 4-4. Alternative options for groundwater management in the Azraq region .................96 Table 6-1. Water tariff for registered and unregistered wells (Bylaw 85-2002/4, and

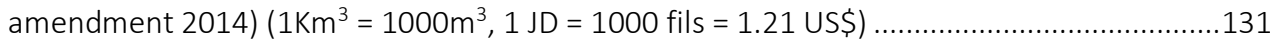

Table 7-1. Details on Azraq farm typology (5 main categories only) .....................................151

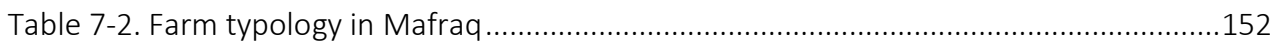

Table 7-3. Tariff for licensed wells all over Jordan (Bylaw 85-2002)(1 JD = 1000 fils) ............156

Table 7-4. Water tariff for wells with permits in Azraq area (2002 Bylaw and amendments)

156

Table 7-5. Water tariff (fils/m3) for illegal wells as amended in 2003 and 2014 (Bylaw 85-

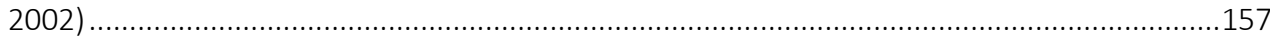

Table 7-6. Production costs in Azraq and Mafraq, according to farm type ..............................157

Table 7-7. Average gross margins for different farm categories under several water pricing

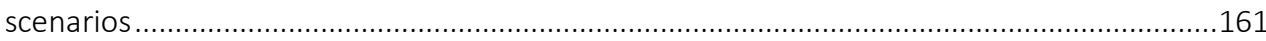

Table 8-1. Accessibility of production factors in both Azraq and Mafraq..............................176 


$$
\text { - }
$$


CHAPTER ONE

Introduction 



\section{Chapter One: Introduction}

\subsection{Context}

Many countries face limitations in the availability and accessibility of surface water. As a result, groundwater resources receive increased attention as the most reliable source of fresh water for different sectors (Vrba and van der Gun, 2004; Llamas and Martinez Santos, 2005; Hammani et al., 2009). Groundwater is the earth's largest accessible stock of unfrozen fresh water and constitutes about $94 \%$ of all fresh water (Chevalking et al., 2008). Currently, groundwater meets over $75 \%$ of water demands in countries like Russia, Jamaica, Saudi Arabia, Georgia, or Libya (Vrba and van der Gun, 2004), and up to $100 \%$ in Denmark (Flindt Jørgensen et al., 2016). Globally, it was estimated that $70 \%$ of withdrawn groundwater is used for agriculture and that groundwater provides almost half of all drinking water worldwide (NGWA, 2016).

The use of groundwater has grown exponentially during recent decades, especially in the agricultural sector (Chevalking et al., 2008). Global abstraction for groundwater-based agriculture has increased from a level of 100-150 Billion $\mathrm{m}^{3}\left(\mathrm{Bm}^{3}\right)$ in 1950 to $666 \mathrm{Bm}^{3}$ in 2010 (IGRAC, 2010). Groundwater extraction now supplies $43 \%$ of the water used in agriculture (FAO, 2010; WWDR, 2015).

The increase in groundwater-based agriculture has been generated by different supply- and demand-driven factors (Shah et al., 2007). Supply-driven factors include easy availability of inexpensive pumps and drilling technologies that facilitate the access to groundwater through government subsidies for wells and pumps or agriculture in general, (Shah et al., 2007). Demand-driven factors include the increase in population, which lead to increase in agricultural activities to support rural livelihoods and feed urban populations (ibid.). In some regions, the growing commitment of increasingly variable surface water resources made it necessary to complement supply with, and shift to, groundwater.

The intensive use of groundwater has been a key factor that transformed rural economies in various parts of the world (van Steenbergen and El Haouari, 2011). Use of groundwater allowed for an increase in irrigation, resulting in higher cropping intensities and productivities and expansion of agricultural areas. For example, use of groundwater allowed farmers in China to cultivate two crops of maize and wheat per year instead of three rainfed crops of maize and wheat in a two-year cycle (Wang et al., 2006). As a result, some countries increased their agricultural production and even became exporters, like Bangladesh with regard to rice (Palmer-Jones, 1999) and Saudi Arabia with regard to wheat (Abderrahman, 2003).

Due to the intensive use of groundwater, groundwater is over abstracted and depleted in many regions (Konikow and Kendy, 2005). Abstraction of groundwater in specific aquifers exceeds recharge by $100 \%$ to $200 \%$ in countries such as Saudi Arabia, Yemen, Jordan, Morocco and India (Hellegers et al., 2008; FAO, 2009a; MWI, 2009; Garduno et al., 2011), and $1000 \%$ in parts of the Ogallala aquifer, in the United States (Guru et al., 2000).

Over abstraction manifests itself through declining groundwater levels in many major aquifers globally, with a typical range of 0.5 to $5 \mathrm{~m} / \mathrm{yr}$ (Guru et al., 2000; Khater, 2002; Bajjali and Al-Hadidi, 2005; Elmore et al., 2006; Khair et al., 2010; Gaur et al., 2011; Zhou et al., 


\section{Chapter 1}

2013). This can be briefly illustrated by a few examples. The yearly decline in groundwater levels reaches 2-3 m/yr (or more) in Baluchistan, Pakistan (Khair et al., 2010). Elmore et al. (2006) noted a decline in groundwater level between 0.5 and $5 \mathrm{~m} / \mathrm{yr}$ in the Owens Valley, Eastern California. Significant decline in groundwater levels in the Beijing Plain, China has been observed since the 1970s, with a total drop in groundwater of more than $20 \mathrm{~m}$ (Zhou et al., 2013). Prakash and Ballabh (2004) observed that in Northern Gujarat, in the west part of India, the water table declined by $2.5 \mathrm{~m} / \mathrm{yr}$ since 1960 . These and many more examples illustrate a general state of overexploitation of groundwater in major irrigated agricultural regions globally.

Although groundwater use may have led to rapid economic development in the short run, the excessive use of groundwater resources may also lead to a wide array of social, economic and environmental consequences, such as: increases in the vulnerability of agriculture mainly for small farms, increase in pumping costs and energy usage, competition for water between sectors, critical changes in groundwater flow patterns, decline in water quality, decline in stream base flow, and damage to springs and wetlands (FAO, 2003; Goode et al., 2013).

The expansion of groundwater-based agriculture has accelerated, especially in desert areas where groundwater is the only available reliable resource to be used for irrigation. We define here groundwater-based agriculture as agriculture that only depends on groundwater resources for irrigation purposes and 'desert agriculture' as "the groundwater-based agriculture developed in steppe or desert regions where rainfed agriculture is impossible due to limited precipitation", and take it as the object of investigation of this research in the particular case of Azraq basin in Jordan.

\subsection{Research objectives}

The acceleration of groundwater-based agriculture globally has been associated with a deep concern for the overexploitation of aquifers resulting from the expansion of this type of agriculture. Controlling abstraction and keeping it close to whatever target is defined as 'safeyield' is proving almost impossible in contexts where agriculture users are in high numbers and spatially scattered (Molle and Closas, 2017).

But beyond the central issue of water access, desert agriculture also comes with distinct characteristics and challenges: these possibly include remoteness and lack of transportation means, higher costs of marketing, limited availability of labor, harsher climatic conditions (wind, frost, etc), the need for considerable capital to kick start cultivation, problematic land tenure status, higher energy costs (e.g. no connection to the grid, pumping from deep aquifers, etc). These possible specific challenges are worth being studied in more details in a context where 'desert agriculture', most notably that which corresponds to large-scale corporate investments, seems to be on the rise globally (Dixon, 2017).

The main objective of this thesis is to contribute to the conservation and sustainable use of limited groundwater resources in desert agriculture. This study has therefore analyzed the current unsustainable use of groundwater in desert agriculture, focusing on groundwater policy on the one hand, and on the specificities of desert agriculture, on the other, with view to discussing the future of the latter in the particular case of Azraq basin in Jordan. Several questions are addressed to achieve this research objective. 


\subsubsection{Research questions}

The main research question of this research is:

What are the physical, economic and political conditions that undergird the development of desert agriculture in Jordan, and most specifically Azraq Basin, and what is the future of this type of agriculture?

This main research question leads the researcher to define several sub questions:

- RQ1: What are the driving forces of desert agriculture development in Jordan and the Azraq basin?

- RQ2: How do public policies respond to the resulting overexploitation and depletion of groundwater resources?

- RQ3: How do desert agriculture entrepreneurs access the various production factors needed for cultivation in such a specific environment and what particular problems do they face?

- RQ4: Is desert agriculture in Azraq basin economically feasible, and environmentally sustainable? and what are possible prospects for the future?

- RQ5: What lessons can be drawn from the study of Jordan for desert agriculture in the MENA region?

\subsubsection{Research hypotheses}

This research hypothesizes that, despite its recent boom, desert agriculture faces specific challenges (accessibility and availability of land, water and production factors) that need to be unpacked and analyzed in order to better comprehend its present and future states; the researcher also posits that the centrality of groundwater in Jordan's limited water endowment, and the overexploitation of this resource, makes it a prime example to study the effectiveness and diversities of groundwater policy measures that can be brought to bear in the face of such extreme challenges. The lessons drawn from this research will be valuable for the many countries in the world - most particularly those of the MENA region - which face or will soon face similar challenges.

\subsection{Research tools}

The research combines both physical and human geography, and has an empirical focus. It is based on the collection and analysis of three different types of information: textual documents, semi-structured questionnaires of key-informants, structured questionnaires of a sample of farmers in Azraq.

\subsubsection{Published information}

Extensive literature search has been carried out on core-issues related to this research, including groundwater policies, land tenure in the Arab world, desert agriculture in Jordan and in the MENA region. This included conventional scientific articles, theses, and consultant reports produced by the numerous aid/cooperation projects carried out in Jordan in the fields of groundwater and agriculture. 


\section{Chapter 1}

The researcher has also extensively resorted to press articles in English and Arabic which reflect government communication (e.g. with regard to implementation of groundwater policy and enforcement of law) but also report instances of conflict around land and groundwater in Jordan.

Statistical and qualitative data from the Ministry of Water and Irrigation, Ministry of Agriculture, Water Authority of Jordan, Department of Lands and Survey, and Department of Statistics have also been collected to analyze trends in the water and agricultural sectors. The national database of law through the "Official Journal -Prime Minister" has been made use of to study the history of water and land laws.

\subsubsection{Semi-structured questionnaires of key-informants and conferences}

General or specific information has also been obtained through the interviews of nine policymakers, project consultants and experts - both foreign and Jordanian -, NGOs and associations (e.g. RSCN; Azraq Wetland, IUCN, UNDP, GIZ, Mercy Corps and USAID), academics and university professors.

All these informants provided various data and perspectives on land, water, agricultural and political issues at different scales and levels. Because some information was sensitive or given under the condition of anonymity these informants were only referred to by their function ('university researcher', 'expert', 'high-level MWRI official', etc).

As a consultant involved in the USAID-funded project on "Groundwater Governance in the Arab World", I have also been involved in discussions with the researchers in the project and various officials, and in scientific roundtables and workshops where relevant information was provided and discussed:

- Groundwater Governance in the Arab World: taking Stock and Addressing the Challenges, Research Update in Groundwater Policy, Management, Water Governance and Future Challenges in Azraq Basin, Jordan (Amman, 29 October 2014).

- Regional Dialogue on Groundwater Governance (Cairo, 8 - 10 September 2015).

- Groundwater Dialogue, Jordan Stakeholder meeting (23 - 25 May 2016).

\subsubsection{Structured questionnaires of a sample of farmers in Azraq}

As part of the abovementioned USAID funded project I carried out a detailed farm survey in two locations of the Azraq basin: Eastern Mafraq and Azraq wetland area proper. The fieldwork was carried out in 2013 and 2015, and 80 farmers (local residents, investors, past farmers) were interviewed through questionnaires. The questionnaires covered issues of land tenure, cropping patterns, production, water and energy sources and use, animal breeding, crop/farm budgets, future perspectives on Azraq, and responses to/perceptions of groundwater policies. Because of the sensitivity of the topic and the reluctance of some interviewees to be cited, the information gathered is anonymized and interviewees are referred to as 'Farmer'.

\subsubsection{Methodology and thesis structure}

The research is divided into three main successive parts, illustrated in Figure 1-1, and covering the physical, the policy, and the economic and sustainability contexts. The research starts with a review of the situation of groundwater use and depletion globally, as well as of 
the different policy tools and approaches available to manage groundwater. The focus then moves to groundwater-based agriculture in desert areas of the MENA region, highlighting the driving forces and specific conditions and constraints of such an activity in five selected countries of Middle East and North Africa. This topical review is followed by a general description of Azraq Basin, the case study chosen for this thesis, with a spatial explorative analysis elaborated using all available data related to the area in order to define windows for possible intervention.

The thesis then moves to examining in more detail the key areas of land and groundwater policies, with detailed historical studies and analysis elaborated. They combine two approaches. The first one is a formal study that analyzes historical land tenure and groundwater laws and by laws. The second approach is based on interviews and interaction with groundwater users, governmental bodies, and policy makers via face-to-face meetings. The study of land tenure focuses on land conflicts in semi-desert and desert areas of Jordan, connecting it with the expansion of irrigated agriculture within the Azraq basin. A historical review of land tenure issues is provided, examining the different ways by which state land can be privatized, highlighting the conflicts around rights to desert land in the past 30 years, while focusing on Azraq basin as a case study. The study results lead us to discuss legal pluralism and the interplay between state and tribal power, and to analyze the twin strategies of accessing land and groundwater in desert areas.

After studying land tenure and how it affects the expansion of agriculture in Azraq basin, the thesis moves to the area of groundwater policies. I first study groundwater laws and by laws and their amendments throughout the years, examine the main tools implemented by the Jordanian government to control well expansion and water abstraction. I then use results from field work to go beyond formal legalism to study the application of policies on the ground, how farmers react toward these measures, and how government in return reacts to farmers' behaviors. This offers a crude perspective on the limits of state regulatory power.

I then turn to the economic and sustainability contexts of desert agriculture in Azraq, with an in-depth survey based on a questionnaire applied in the two main agricultural areas of the Azraq basin (Azraq and Mafraq). Two farm typologies are elaborated based on the questionnaire results, and the variability of farm gross margins highlights the differences between the two agricultural areas. Current cropping pattern are described, water productivity and consumption assessed for each farm, and annual farms profit calculated, with averages for each farm type.

Finally, several scenarios are presented about the sustainability of farming systems in Azraq, reviewing the constraints and changes in the access to, and costs of, land, energy, water, labor and input factors in desert agriculture, reflecting on their bearing on current dynamics and future prospects of Azraq's agriculture. The thesis ends with a short regional perspective on how Azraq case relates or differs from the expanding desert agriculture in the MENA region. 


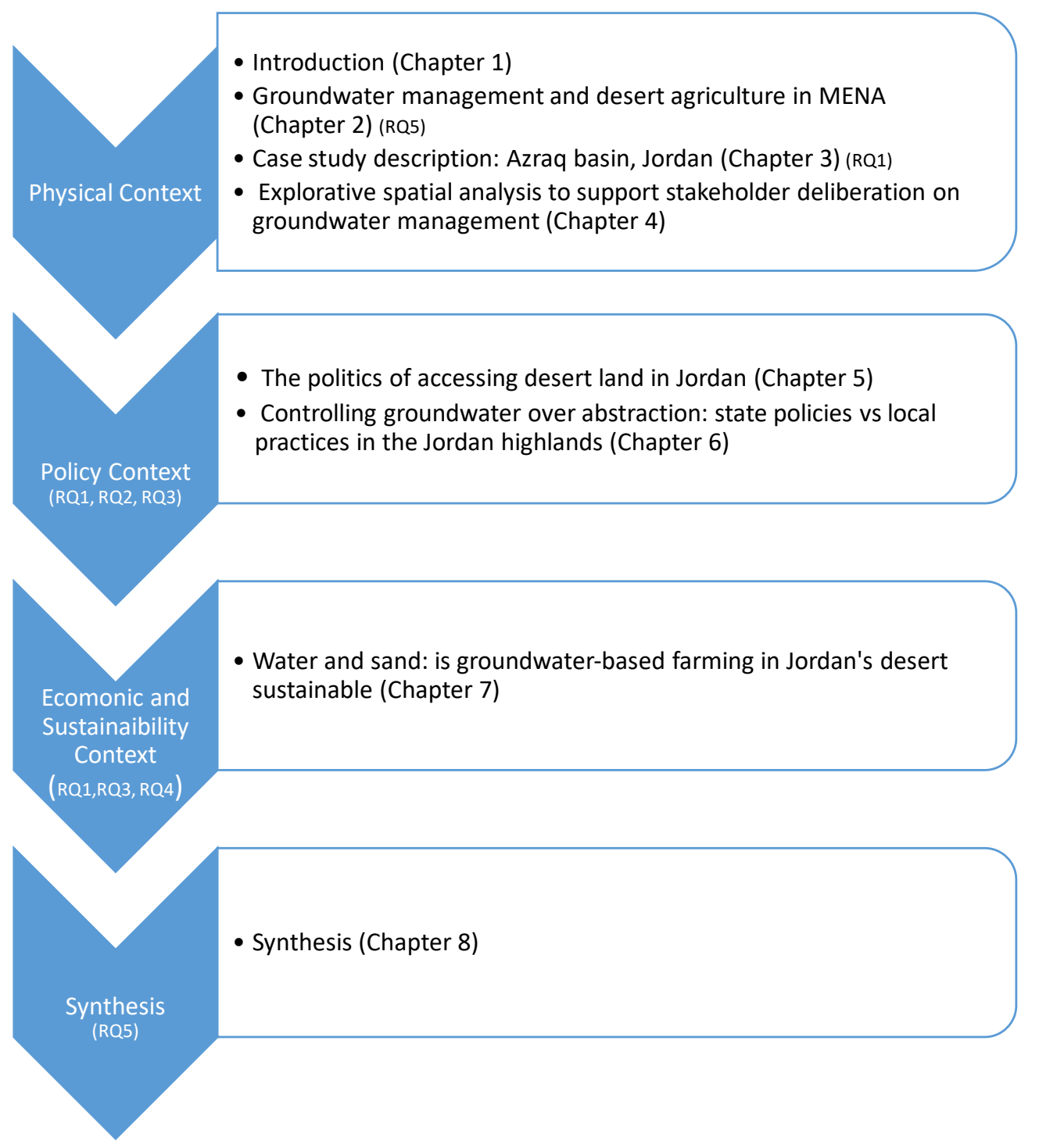

Figure 1-1. Structure of the thesis 
CHAPTER TWO

Groundwater Management and Desert Agriculture in the Middle East and North Africa Region 



\section{Chapter Two: Groundwater Management and Desert Agriculture in the Middle East and North Africa Region}

\subsection{Groundwater resources in Mena region: usage and management}

This section reviews the general features of groundwater usage in agriculture in the MENA region and explores the management and policy options available to regulate this sector. It documents 'desert agriculture' in selected countries of the MENA region, examining in particular how farms access the key production factors of land, water, labor, capital.

\subsubsection{Groundwater usage}

Due to limitations in surface water resources and an increasing water demand associated with population growth and the priority given to domestic use, groundwater in Middle East and North Africa (MENA) region is now the key to both urban and agricultural development, especially in desert areas where it is the only available reliable and accessible resource for irrigation. Each country in the MENA region has its own specific purposes when it comes to groundwater use in agriculture, including urban expansion into deserts, achieving national food sufficiency, economic growth through agribusiness development.

Until 1970s groundwater was extracted using traditional tools and the dependably on groundwater use for irrigation was very minor, but the reliance on groundwater use for irrigation has increased since then, along with irrigation development, new drilling and pumping techniques, and energy availability. As a result, the percentage of irrigation based on groundwater is estimated at $68 \%$ in Algeria, 11\% in Egypt, 60\% in Syria, 53\% in Jordan, 40\% in Morocco, 61\% in Tunisia, 100\% in Yemen, 99\% in Libya and $22 \%$ in Lebanon (FAO, 2009b).

In most cases, governments support and subsidize groundwater use in agriculture. The level and type of government encouragement varies from country to country. In Algeria, groundwater-based agricultural development is encouraged through bank loans for farmers and fund irrigation improvement and tractors (Imache et al., 2010). In Egypt, groundwaterbased agriculture has been developed through land reclamation projects with the objective of reclaiming desert land to expand the total area of arable land and settle populations (Allan, 2001; Adriansen, 2009; Dixon, 2017). In Syria, the large-scale expansion of groundwater-irrigated areas was initiated when the government encouraged and supported the drilling of wells (Munlahasan, 2007; Aw-Hassan et al., 2014). Farmers have access to generous loans to drill wells and install pumps, and heavily subsidized energy prices (De Châtel, 2014). In Jordan, government encourages this activity by giving loans to farmers and subsidies for irrigation systems, and allocating state lands to peasants (UNDP, 2013). In Morocco, despite the worrying status of the main aquifers, the government has provided subsidies to well drilling and micro-irrigation (Molle and Tanouti, 2017). In Tunisia, farmers are offered subsidies of 40 to 60 percent of their total investment costs for water saving irrigation technologies (Frija et al., 2014). In Yemen, groundwater-based agriculture is encouraged by bank loans for drilling wells (Closas and Molle, 2016). In Libya, farmers have benefit from the heavily subsidized energy (World Bank, 2007). In Lebanon, groundwaterbased agriculture has been encouraged by crops and micro irrigation technique subsidies (Nassif, 2016). These encouragements and subsidizes boosted the expansion of groundwaterbased agriculture and increased the reliance on groundwater resources. 


\section{Chapter 2}

As a result, the cultivated areas have increased exponentially in all countries. In Egypt, the cultivated area is in continuous increase as the government has recently launched a new project to further expand desert reclamation by 16.8 million du based on groundwater and Nile resource (MetaMeta, 2015). Cultivated area in Syria increased from 3 million du in the 1980s to 7 million du within a few years (Aw-Hassan et al., 2014). In Jordan, the cultivated area in the highlands increased from 362,110 du in 1994 to 761,685 du in 2016 (DoS, 2017). In Yemen, the cultivated area increased from 370,000 du in 1975 to around 4 million du in 2005 (NWRA, 2009). In Libya the total groundwater-irrigated area in 1990 was estimated at 4.7 million du, with plans to expand up to 7.3 million du by 2025 (Khater, 2002). In Lebanon, the irrigated area rose from 400,000 du in 1960s to 1.2 million du in recent years (MoA and FAO, 1963, 2010).

The increase in cultivated areas is associated with increasing in agriculture wells number. The number of existing wells provided by official statistics usually underestimate reality because inventories are rarely up-to-date, and the proportion of unknown wells can be large. Even with such uncertainty, reported numbers are staggering. In Algeria, the number of wells increased from few thousand in the 1980s reaching 113,600 wells in 2008 (FAO, 2008b). In Egypt, the total number of wells in the whole delta was estimated by the ministry of water and irrigation in 1992 with 10,420 wells and increased in 2012 to 23,000 wells (MWRI, 2012). However, a study conducted by El-Agha et al. (2017) about the groundwater based agriculture in the central Nile Delta highlighted that groundwater use remains a blind spot and estimated that the total number of wells in the delta could now exceed 73,000 wells, seven times higher than it was in 1992 (ibid.). In Syria, the total number of wells in the 1980s was estimated at 53,000, but this number boomed in the 1990s and in 1994 the (official) number of wells reached 124,000 (Aw-Hassan et al., 2014). Number of wells in Jordan increased from few hundreds in the 1980s up to around 4000 wells in 2017 (Molle et al., 2017a). In Tunis, the total number of wells doubled between 1980s to 2000 reaching 120,000 wells (Gaubi, 2008) and then it increased to more than 137000 wells in 2008 according to FAO (2009c). In Yemen, the number of wells increased from a few thousands in the 1970s to more than 50,000 in 2007 (Hellegers et al., 2008). In Lebanon, the number of wells in the 1970s did not exceed 3000. In 2003 the number increased to around 10,000 registered wells and at least 40,000 non-registered wells (Ghiotti and Riachi, 2013; World Bank, 2003). More recently, UNDP (2014) estimated non-registered wells at around 59,000, against 20,500 registered wells.

The intensive use of groundwater in the MENA region has caused severe depletion of the resource due to abstraction exceeding the safe yield in most aquifers. This extensive use has caused a decline by up to $1 \mathrm{~m} / \mathrm{yr}$ in the North Algerian aquifers (FAO, 2008b) and in the Egyptian west Delta aquifer (Dixon, 2017). In Syria, a study done by Margane (2003) found that in the 1993-2002 period groundwater levels in the Ghuta (Damascus) and its surroundings dropped by more than $6 \mathrm{~m} / \mathrm{yr}$. Groundwater was found to be declined in Jordan with an average value of $0.8 \mathrm{~m} / \mathrm{yr}$ (Goode et al., 2013). Decline in groundwater tables was observed in Morocco by $30 \mathrm{~m}$ on average in the past 25 years (FAO, 2008a; Saidi, 2012). In Tunis, water table was noticed to be declined by 1-14 $\mathrm{m}$ in the different piezometers controlled by the Ministry of Agriculture (Ben Hamouda, 2008). In Yemen, JICA (2007) reported a yearly decline in groundwater levels by $7 \mathrm{~m}$ in Sana'a basin and overdraft of around four to five times the recharge, $5 \mathrm{~m}$ in Northern Highlands basins, $4 \mathrm{~m}$ in Taiz basin, while overdraft in Wadi Hadhramout basin was seven times the recharge. Ben Ghashir, the 
heaviest groundwater extraction zone of the Jefara Plain in Libya, faced an extensive decline in water table with groundwater levels falling from $17 \mathrm{~m}$ below the ground surface in 1958, to $37 \mathrm{~m}$ in 1970, and to $92 \mathrm{~m}$ in 1989 (Salem, 1991). In Lebanon, groundwater in the Beqaa valley, has drawdown reached $40 \mathrm{~m}$ between 1970 and 2010 (Nassif, 2016).

Such dramatic drops in water levels have come along with a host of negative consequences. Sea water intrusion was noticed in some costal area countries such as Gaza (Al-Jamal, 1996), Bahrain (Zubari and Lori, 2006) and Algeria (FAO, 2008b). A sharp decline in springs natural flows was recorded in Lebanon (Nassif, 2016) and Morocco (van Steenbergen and El Naouari, 2010), while other springs dried up in Jordan or Syria (Margane, 2003; De Châtel, 2014). Increase in water salinity and deterioration in water quality were observed in Tunis (Faysee et al., 2011), Syria (Arraf, 2016), Jordan (El-Naqa, 2010), Egypt (Dixon, 2017) and Lybia (Khater, 2002) as result of tapping deeper layers of the aquifers.

What can be concluded from this overall review of groundwater use in the MENA region? It is observed that groundwater use in agriculture has been accelerated since 1970 with a direct and indirect government encouragement. This use is associated with increase in cultivation area and wells number. The intensive use of groundwater causes a pattern of severe overexploitation, with water tables dropping by an average between 0.3 and $3 \mathrm{~m} / \mathrm{yr}$., seawater intrusion in coastal aquifers, drying up of springs and river beds, uncertainty when it comes to the number of functioning wells and huge numbers of illegal wells. Much of this imbalance has been initially generated by state subsidies supporting well drilling or agricultural expansion.

The next section will focus on tools and instrument of groundwater management at aquifer level in the MENA region and how these tools often encourage groundwater-based agriculture rather than controlling it to some extent.

\subsubsection{Aquifer management}

While the preceding section has focused on documenting the status of groundwater use in the MENA region, we turn here to the types of management approaches and tools that can be found in the region. Molle and Closas (2017) have classified state-management tools according to the policy objective: 1) augmenting supply; 2) controlling the number and expansion of wells; 3) controlling abstraction in existing wells (Figure 2-1). The researcher chose here to follow OECD (2015), Faysse and Petit (2012) and others to distinguish between 1) regulatory tools; 2) supply augmentation; 3) demand-management; 4) communitymanagement options.

\subsubsection{Regulatory tools}

Management of groundwater resources use in MENA region is controlled by legislation and regulations. Faysse et al. (2011) and Closas and Molle (2016) have listed and discussed a number of policy instruments and tools for groundwater management and where these are applied in the Arab world (Table 2-1). 


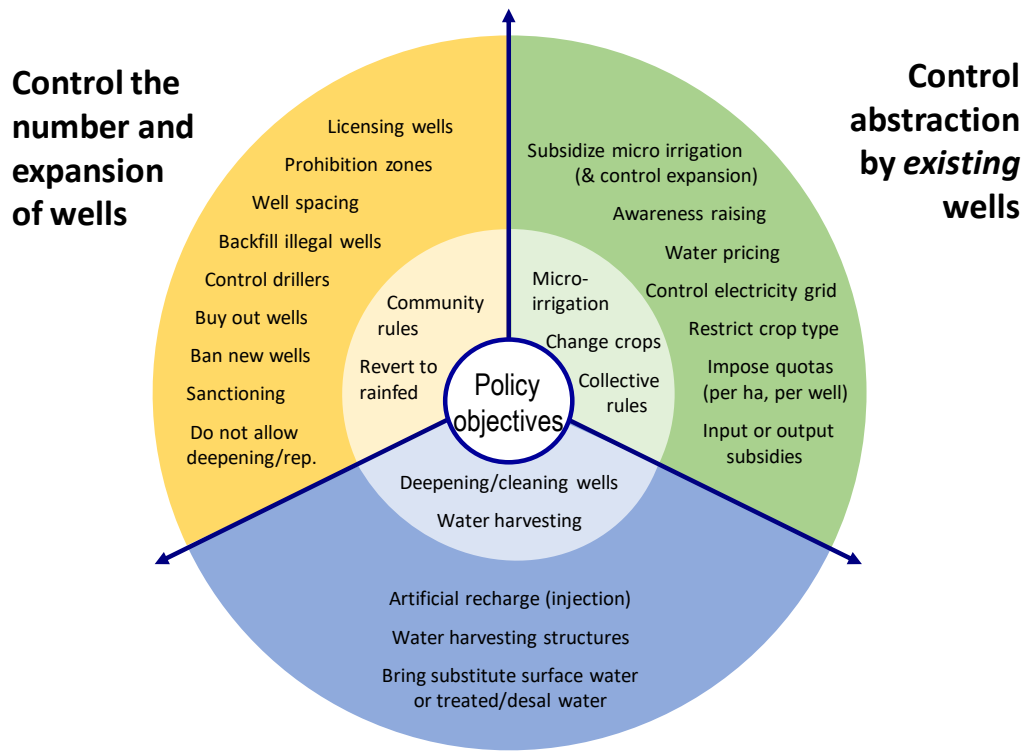

\section{Manage supply}

Figure 2-1. Main groundwater policy objectives and tools (Molle and Closas, 2017)

Table 2-1. Main regulatory tools used in MENA countries (adapted from Closas and Molle, 2016)

\begin{tabular}{|l|l|}
\hline Tool & Examples of implementation \\
\hline Permits & Syria, Morocco, Egypt \\
\hline Well spacing & Lebanon \\
\hline Well drilling prohibition zones or well bans & Algeria, Egypt, Jordan, Lebanon \\
\hline $\begin{array}{l}\text { Limitation or ban of electric connections to wells or labor } \\
\text { permits }\end{array}$ & Tunisia, Jordan \\
\hline Well buy out or backfilling & Jordan \\
\hline Control of drillers & Jordan, Oman, Yemen \\
\hline Quotas & Jordan, Lebanon, Tunisia, Yemen \\
\hline Well zoning & Syria, Tunisia \\
\hline
\end{tabular}

Well control can be achieved using different tools such as introducing a well registry and/or permit system, defining a minimum spacing between wells, or delineating prohibition areas were aquifers should be conserved.

New technologies are adopted to assist in groundwater management, like GIS and remote sensing which help control illegal well drilling and cultivated area expansion.

All MENA region countries have introduced a registry system for wells whereby licenses or permits are required. Different licenses are sometimes granted for the act of drilling/constructing the well first, and then for exploiting the well (e.g. Lebanon, Jordan). The procedure for obtaining well licenses may vary from country to country: in Yemen for example, wells should have licenses permitting a specific amount of abstraction under the 
control of the National Water Resource Agency (Morill and Simas, 2009), although no tangible monitoring takes place and most wells do not have a permit (ibid.). In Jordan, drilling first requires a permit and all working wells should then have licenses or permit and a metering system. Each well has its own specificity in allowable water abstraction and fees for water use (Molle et al., 2017a). In Lebanon, a well permit is a must for wells that are deeper than $150 \mathrm{~m}$ and use fees are applied for wells that discharged more than $100 \mathrm{~m}^{3} /$ day (Molle et al., 2017b).

Oftentimes, when registration systems are established or tightened up, the question of the legalization of existing wells comes up. As documented by Molle and Closas (2017) for countries like Morocco, Jordan, Lebanon, but also Mexico or South Africa, this is a tedious and never fully achieved process. Faysse et al. (2011) have also stressed the difficulties of well registration in Morocco, where farmers have been suspicious of the state intention of giving them a period for well registration. Generally, they only declared their boreholes if they needed a deepening authorization or a subsidy for micro-irrigation (Faysse et al., 2011). In Tunisia, the lack of farmer technical knowledge about the aquifer status and a weak law enforcement, compounded after the Arab spring in 2010, have caused an increase in the number of illegal wells (Frija et al., 2014).

Countries can also control illegal expansion of well drilling indirectly, by controlling well drillers. In Yemen, all drilling rigs must meet technical specifications issued by the NWRA (Morill and Simas, 2009). In Oman, only government registered contractors are allowed to construct and maintain wells and install pumps (ibid.). In Jordan a driller permit is issued for a period of one year and it is subject to yearly renewal, with penalties in case of illegal practice (more details in Chapter 6). Yet, such regulations have been insufficient to wipe out illegal well drilling.

\subsubsection{Supply management}

Historically, water resources management and policies were supply driven only (Bakir, 2001). Countries in the MENA region have developed large-scale infrastructure and public irrigation schemes, mostly based on surface water diversions. This includes large-scale projects in the Tigris-Euphrates plain (Syria and Iraq), the Ghab (Syria) and Jordan Valley (Jordan), expansion of cultivation in the Nile Delta and its vicinity, and several large- to medium-size schemes in 'Maghreb countries, notably Morocco. Withdrawals for all types of use, whether planned or not, have taken their toll on river systems and, later, aquifers, following classic trajectories of 'river basin closure' (Molden et al., 2001; Molle et al., 2010). Although water-demand management has then been promoted, it is always tempting for decision-makers to attempt to mobilize more water, even if this is economically irrational. Spreading costs over the state budget is invariably seen as a better political option than adopting regulations or tools which would result in people having less or more costly water (Molle, 2008). With renewable fresh groundwater being almost fully exploited, supply augmentation options, aside from additional dams, have considered non-conventional sources of supply, such as wastewater treatment, desalination, managed aquifer recharge or water imports (Bakir, 2001; Khater, 2002). It is hoped that resorting to available alternative supplies will help conserve the limited remaining groundwater (Khater, 2002; Shah, 2007), but more often this 'new' water only helps absorbing growing needs, if not spurring more use and consumption (Molle et al., Forthcoming). In general, the use of non-conventional sources of water is costly. Wastewater 


\section{Chapter 2}

needs a treatment plant, seawater desalination needs expensive technology and a lot of energy, and water transfers need pipes, canals, tunnels and pumping stations, and frequently have third-party and environmental impacts.

Artificial groundwater recharge is one of the means to manage and conserve groundwater resource that will enhance available groundwater stocks (Abu Jaber, 2001; Khater, 2002; Al Raggad and Jassem, 2010; Hamdane, 2014). Artificial recharge can be done directly by injecting fresh water directly into aquifers or indirectly by building dams, ponds and catchment to 'harvest' runoff during the wet season(s) (El Naqa and Al-Shayeb, 2009). This method is already implemented in Jordan, Saudi Arabia, Yemen, Oman, UAE, Tunis and Qatar (Khater, 2002; UNESCO, 2014; Closas and Molle, 2016). In Tunis, aquifer recharge using small dams accounts for $4 \%$ of the total recharge volume of the country (Hamdane, 2014).

Treated wastewater, and sometimes even desalinated water (e.g. in Abu Dhabi), can be used to artificially recharge groundwater aquifers. Despite the advantage of artificial recharge, problems might still occur in some countries as land to construct recharge facilities may not be available or may be too expensive to acquire. Aquifer contamination and change in water physical and chemical properties are also problematic, especially when the source of recharged water has different quality than the water preserved in the aquifer (Bakir, 2001 and Khater, 2002). Tunis is one of the countries that use wastewater to recharge groundwater aquifers (Louati and Bucknall, 2009; Ouelhazi et al., 2014).

Use of treated wastewater for agriculture is one popular option nowadays in MENA region countries (FAO, 1997; FAO, 2009b; Bakir, 2001). In 1997, FAO reported that Jordan has started using $50.3 \mathrm{Mm}^{3} / \mathrm{yr}$ of this source for irrigation since in the Jordan Valley (FAO, 1997). In many countries farmers abstract wastewater directly from drain and rivers, whether it is partially treated or not at all (e.g. Egypt, Algeria, Morocco). In Tunis, wastewater is used for agriculture since 1989 (FAO, 2009c), it represents around 30\% of the country's agriculture water supply. Bahrain has expanded its infrastructure in non-conventional water sources with a total capacity to treat wastewater in 2012 of $36.1 \mathrm{Mm}^{3}$ (Al Insari, 2013). Oman also has introduced wastewater reuse (Zekri, 2008).

Desalination is an important source of alternative water supply in the Gulf States as it accounts for more than $55 \%$ of the total water withdrawn urban area of Bahrain, UAE, Qatar and Kuwait (UNDP, 2013). Saudi Arabia and UAE jointly produce more than $30 \%$ of the world's desalinated water (UNESCO, 2012; Ragab, 2013). Tunis started in 1995 a large program of investment to improve water quality of public drinking water, tourism and industrial through installation of desalination plans (Gaubi, 2008). Bahrain also started to use treat wastewater and desalination water for agriculture use and keep the groundwater resource for drinking purposes only (Zubari and Lori, 2006; Al Insari, 2013; Al-Zubari, 2014).

Local and transboundary water transfers are also considered as one of the options to bring in more water and meet demand and/or reduce groundwater depletion. Jordan tried to explore this option with Turkey but it was never applied for political reasons. On the other hand, it worked for the Syrian part but for a small-scale water transfer only, helping Jordan to alleviate the summer water shortage (Bakir, 2001). Morocco has future plans to transfer water from the north of the country to the south, as indicated in the country's water strategy for 2030. It expects to transfer around $845 \mathrm{Mm}^{3} / \mathrm{yr}$ (OECD, 2017). Closas and Molle (2016) indicated that the transferred water can be used for drinking purposes in Marrakech city, 
which will decrease the pressure on already stressed Haouz aquifer (ibid.). Egypt also has a plan to transfer Nile water to the groundwater-based West Delta area (Barnes, 2012). The implementation of this project has been delayed due to the 2011 Revolution and other problems (Closas and Molle, 2016).

Water transfers are also resorted to in Tunisia, from the north and west of the country towards the more urbanized coast and the Cap Bon core agricultural region. Water is in particular transferred from the Medjerda basin (north-east) to Sfax (western Tunisia). They are also very common in Algeria, where water from surplus catchments from the west, and from fossil aquifers in the south, is transferred to the north-western coast with both surface and groundwater deficits (Demmak, 2010).

\subsubsection{Demand management}

Demand management means "the application of a range of physical and economic measures to achieve higher efficiency in the way water is utilized" (Khater, 2002). It can also be defined as "the management of the total quantity of water abstracted from a source of supply using measures to control waste and undue consumption" (Herbertson and Tate, 2001). Brooks and Wolfe (2007) defined demand management as "getting the most from the water we have, it includes any action that reduces the amount of fresh water we need, or that keeps water cleaner than it otherwise would be."

Demand management can take many forms, from direct measures to control water use through institutional reforms, updates of water policies and monitoring the implementation of regulatory tools and instruments -, to indirect measures such as market mechanisms, financial incentives and public awareness programs (Khater, 2002; Brooks and Wolfe, 2007; USAID, 2011).

Introducing water tariffs and fees, metering systems and using technologies are considered as options to control groundwater abstraction. However, hardly any country in the region charges for groundwater use in agriculture. Jordan is an exception. Water pricing is generally ineffective because the water charge remains small compared with other agricultural inputs, and because in any case the rate of fee recovery is low to nil and not recovered (e.g. Morocco or Lebanon) (Saghir, 2004; Brooks and Wolfe, 2007; Al Naber et al., 2010; Al Naber and Molle, 2017). Water pricing, but also the implementation of quotas or any volumetric management, depends on the existence of metering. Jordan, Syria and UAE are among the MENA region countries that imposed metering systems for groundwater wells to control extraction (Stephan, 2007; Venot et al., 2007a, 2007b). However, it has been noticed from several studies that not all groundwater wells are equipped with a meter in the mentioned countries above. For example, in Amman Zarqa basin, Jordan, 90\% of the wells had a metering system, yet only $61 \%$ were working less than ten years after their installation (Chebaane et al., 2004; Venot et al., 2007a). Chebaane et al. (2004) emphasized farmers' perspective about meters, seen as unreliable tools for monitoring and controlling groundwater pumping, and the widespread occurrence of tampering and vandalism (Chebaane et al., 2004).

Raising users' awareness about water scarcity is another avenue. In Jordan, USAID assisted in developing a water demand management strategy for the country since 1999, including projects like 1) Water Efficiency and Public Information for Action (WEPIA) which aimed to 


\section{Chapter 2}

promote water conservation among Jordanians and introduce water demand management principles, 2) Education and Information Program to Improve Irrigation Water Use Efficiency (KAFA'A) that aimed to initiate water conservation among Jordanian farmers in selected areas, 3) Community-Based Initiative for Water Demand Management, that aimed to enable poor communities in rural areas to establish water efficiency programs, 4) Groundwater Monitoring Project, which helped the WAJ to enforce the Groundwater By-Law (USAID, 2011). Lately in 2007-2011, USAID implement the IDRA project in Jordan with the aim of strengthening institutional capacity for water demand management in a number of entities of the water sector.

A key objective of any demand management program is to reduce water losses (Khater, 2002). In most MENA countries, irrigation water system efficiency ranges from $80-50 \%$, which means that loss by seepage at the plot level ranges between $20 \%$ and $50 \%$ (Khater, 2002; Lee and Schwab, 2005). Reduction of leakage by improving irrigation system efficiency increases water supply availability and saves costs (Khater, 2002). Implementation of limited leakage detection programs in the Gulf States succeeded in reducing leakage by $8 \%$ in Bahrain and 15\% in Qatar (Khater, 2002). Irrigation techniques should therefore be changed from basin/gravity irrigation to drip irrigation to improve irrigation efficiency. In addition, national programs and trainings should be conducted to guide farmers on when, how and how much water to apply to different types of crops.

However, in many cases water savings at the plot level do not translate into more water being available at the system of basin level. Molle (2017) has analyzed the case of Morocco, where policymakers introduced subsidies to convert gravity irrigation system into micro irrigation system with the aim to conserve water and increase farmers' profit and farm productivity. Taxes on importing micro-irrigation equipment have been reduced and even canceled since 1982 (MAPM, 2007; Laamari et al., 2011). Subsidies to drip was gradually increased from $30-40 \%$ in 2002 to $60 \%$ in 2006 , and $80 \%$ for large farms and $100 \%$ for farms under 50 du in 2008 (Molle, 2017). By 2014, the annual rate of conversion to drip irrigation was estimated at 500,000 du/yr. Regarding water savings, in 2016 the Ministry reported that the conversion to drip implemented so far had estimated saving of 800 million $\mathrm{m}^{3}\left(\mathrm{Mm}^{3}\right)$, and that "farmers had been able to diversify their production systems and achieve up to three times more production with half the water" (quoted in L'Economiste, 2016). Molle (2017) shows that while "drip irrigation and other measures do indeed have a positive impact on land and water productivity", the quantity of water applied is not necessarily reduced, and even where this is the case farmers take advantage of the new system to cultivate crops in a more intensive way (e.g. by intercropping and increasing the density of trees) (ibid.).

One of the points emphasized by Molle is that irrigation does not necessarily reduce soil evaporation significantly as less soil is wet but it is wet for longer period, while crop transpiration is increased due to increasing in irrigation frequency which causes an increase in productivity (Burt et al., 2004; Molle, 2017). On balance, the safer-and quite conservativeworking hypothesis, also arrived at after a review of the literature by Perry and Steduto (2017), is that drip irrigation reduces applied water on average but is neutral in terms of water effectively consumed.

This situation, also observed in other countries such as Tunisia (WaterWatch, 2008), implies that the real water savings that can be achieved are limited. This physical limitation adds to 
those mentioned for economic tools. But major constraints to demand-management also relate to administrative weaknesses and lack of political will. All in all, Brooks and Wolfe (2007) describe water demand management in the MENA region as a failure as it is linked to the policy "even if policies avow support for water demand management, they commonly falter in application and implementation" (Brooks and Wolfe, 2007).

In conclusion, demand management is a key policy objective but its potential may be less than usually expected or wished for. This includes hydrologic (e.g. scale issue and water savings), socio-economic (e.g. limits to pricing), political (e.g. lack of political will to enforce measures impacting uses and users) and logistic reasons (lack of continuous monitoring of practices).

\subsubsection{Community-based management and co-management}

Groundwater is one of the common-pool resources characterized by costly exclusion and subtractability of units (Ostrom, 2003; Bravo and Marelli, 2008). Common-pool resources are shared by different users, which may generate competition around their utilization, often leading to their degradation and destruction (Hardin, 1968; Bravo and Marelli, 2008).

As groundwater is a fundamental natural resource for life, strategies for sustainable management are a necessity, especially in arid water stressed countries. Local community and participatory approaches are found to be one of the solutions for natural resource management, if proper understanding of over-abstraction and social capital can prompt a collective response by the community of groundwater users (Dayton-Johnson, 2000; Chirenje et al., 2013).

Groundwater community management can either be endogenous or exogenous, or a mixed process between both (Closas and Molle, 2016). Endogenous groundwater community management can be found in a place where oasis, springs, qanats are found. Users in such places have learned to manage village resources through a collective management approach (Wade, 1987; Pinkerton, 1989; Ostrom, 1990, 1992; Stevenson, 2005). Such management is well illustrated by Oman, Morocco, Algeria and Tunisia. Farmers have also been capable of defining collective arrangements to invest in and manage collective wells, like in Morocco or Algeria (Hammani et al., 2009, Faysse et al., 2011; Closas and Molle, 2016). But managing collectively an aquifer is a different matter.

Closas and Molle (2016) consider that "the use of traditional groundwater management system in the Arab world demonstrates that communities have the capacity to manage and share groundwater orderly and cooperatively." Petit (2004) explains that in a situation of water stress local stakeholders often recognize the common character of groundwater resources and try to find adapted solutions to overexploitation. Ghazouani et al. (2012) also demonstrated that farmers are reasonably aware of the constraints of Nefzawa oasis in the south of Tunisia environment due to their long term practical experience. Yet, examples of pure community-based management of local aquifers are hard to find, with Yemen standing out as a country where some local regulations have sometimes been put in place (Taher et al., 2012).

Exogenous types of community groundwater management allow to some extent the involvement of the state in the formation of collective groups or arrangements to oversee 


\section{Chapter 2}

management (Closas and Molle, 2016). This is well illustrated by Jordan where the government established water user associations in the Jordan Valley and with the GIZ initiative in the highlands through highland water forum. It is also presented in Tunisia's GDAs (Closas and Molle, 2017). In such case we can talk of co-management between the state and users.

In Jordan, the Highland Water Forum was a co-management initiative started by GIZ (20102013) under the umbrella of Ministry of Water and Irrigation with an objective "to bring the conflicting water users, particularly the water-governing authorities and the agricultural community, to agreement regarding the causes for dwindling groundwater resources, and to collectively think of creative solutions. "The forum was akin to a multi-stakeholder dialogue, with participants from the farm to the policy level. The main outcome of the forum is an action plan for the sustainable management of groundwater, developed through several meetings with different actors in the basin. The plan was presented to the Minister of Water and Irrigation but no real action had been initiated as of late 2015 (Al Naber, 2016).

In Tunis, the co-management approach is exemplified by the Bsissi case, were the GDA (Groupement de Développement Agricole) is involved in the aquifer management with the local administration (CRDA), with the central aim of controlling the proliferation of illegal wells for agriculture uses. A partnership between stakeholders was established in order to implement a management system for the aquifer. The partnership resulted in creation of the association for the development, monitoring, and exploitation of the Bsissi-Oued El Akarit aquifer. This association was involved in backfilling some illegal wells as well as preventing the drilling of wells (Hamdane, 2015). It also tried to reduce the amount of water used and the total irrigated area (ibid.). This case is believed to be a success but it has not been documented in detail and concerns a limited number of well/well users (100+). It is unclear whether it could be reproduced at a larger scale.

From the above, it can be sensed that while communities in the MENA have proved to have the capacity to manage groundwater resource by themselves in the case of a small irrigation scheme, co-management solutions have to be found for larger/more complex situations.

\subsection{Desert agriculture}

\subsubsection{Examples of desert agriculture}

Arid or desert areas usually have climatic features that preclude rainfed agriculture. But when a source of water occurs naturally (springs in oases) or can be tapped (groundwater, or surface water transferred, like in Toshka, Egypt), intense solar radiation and pest-free environments may become assets for irrigated agriculture. Expanding agriculture into desert lands may become a strategy for either individuals or corporate entities, or for the governments willing to provide settlement/livelihood opportunities and boost agricultural production and/or exports. Earlier I have defined 'desert agriculture' as "the groundwaterbased agriculture developed in steppe (badia) or desert (sahra) regions where rainfed agriculture is impossible due to limited precipitation."

While the first Part provided a bird-eyed view of groundwater use and management in the MENA region, we focus here more specifically on desert agriculture in 5 selected countries of the MENA region, and then briefly reflect on the challenges posed by the need of accessing key agricultural production factors in such extreme environments. These examples will be 
mobilized in the final synthesis part to better underline what is specific to our case study in Jordan, and what wider lessons can be drawn from it.

\subsubsection{Saudi Arabia}

Desert agriculture is quite prominent in Saudi Arabia. The country is characterized by desert climatic condition with limited precipitation and high temperature. Farming in desert started in the kingdom in the 1960s with a total cultivated area of 3.4 million du, increased to reach 12,135,860 du in 2005 (FAO, 2009a) and up to 34,218, 540 du in 2017 (MEWA, 2017). This type of cultivation was encouraged by the government to achieve food self-sufficiency through agricultural support policies, including free-of-interest loans, price incentives to crops, and subsidies for machine and irrigation equipment (Abderrahman, 2005; Ouda, 2014). The agriculture sector accounts for $88 \%$ of the country's water withdrawals, while industrial and municipalities receive only $3 \%$ and $9 \%$ respectively (FAO, 2009a). Groundwater in the kingdom is the main source for irrigation since as much as $97 \%$ of irrigation water comes from groundwater resource, while the rest $3 \%$ is supplied from non-conventional water resources (FAO, 2009a). Sprinkler irrigation system is the most widespread system in the desert farms, with a share of $64 \%$ followed by surface irrigation with $34 \%$ and localized irrigation system with $2 \%$ only. Wheat is the main crop cultivated in the desert followed by fodders, vegetables and fruits.

Figure 2-2 shows groundwater basins in Saudi Arabia. Farming in the desert is mainly located in two areas in the kingdom: Tabuk, with the Saq-Rum aquifer, and Wadi Ad Dawasir, based on Wajid aquifer (Figure 2-2). Saq-Rum is a shared aquifer between southern Jordan (named Disi or Rum aquifer) and the north of Saudi Arabia. It covers a total area of approximately $560,000 \mathrm{~km}^{2}$, of which $82,000 \mathrm{~km}^{2}$ are in Jordan and $478,000 \mathrm{~km}^{2}$ in Saudi Arabia (UN-ESCWA and $B G R, 2013)$.

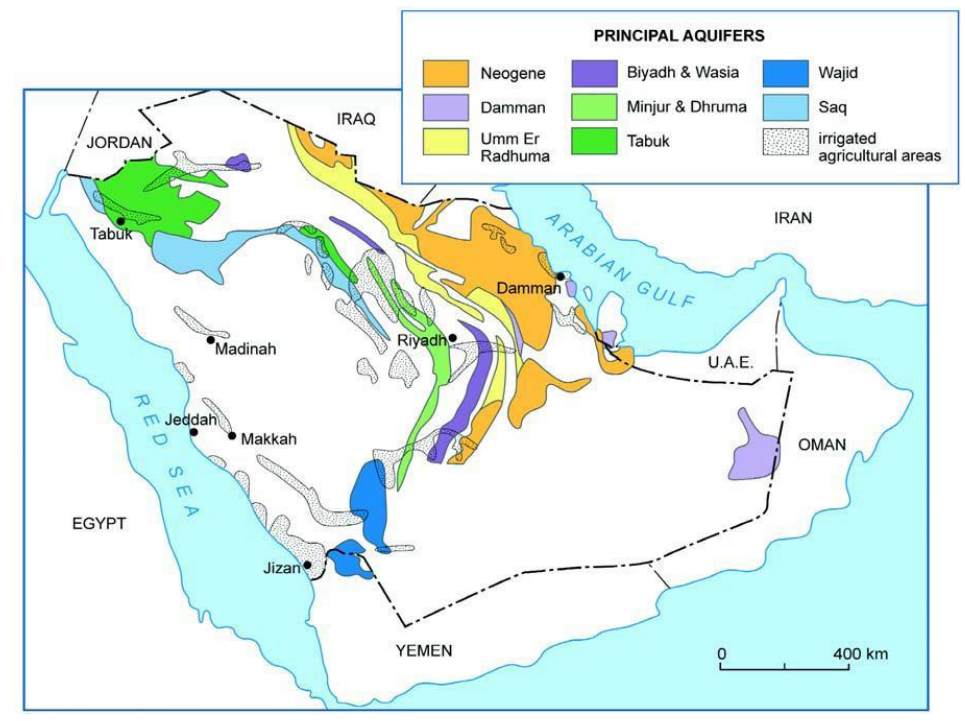

Figure 2-2. Groundwater aquifers in Saudi Arabia (arabgeographers.net) 


\section{Chapter 2}

The aquifer is a nonrenewable fossil aquifer with a thickness varying between $500 \mathrm{~m}$ up to $4000 \mathrm{~m}$ (Charalambous, 2016). Currently, it is exploited from the Tabuk Plain in Saudi Arabia to Wadi Rum in Jordan. Groundwater in Tabuk is used to irrigate extensive wheat production since the late 1970s, with a later substantial shift towards fruits and vegetables produced by private companies (ElHadj, 2004; Ouda, 2014; Charalambous, 2016). In the 1980s, the annual abstraction from Saq-Rum aquifer in the Tabuk area was estimated at $20 \mathrm{Mm}^{3}$, but it rose dramatically to reach $1,000 \mathrm{Mm}^{3}$ in 1990 (Haiste in association with Scott Wilson Kirkpatrick, 1995). In 2000, the abstraction was reduced to $700 \mathrm{Mm}^{3}$ through government initiative to decrease groundwater consumption and discontinue agriculture subsidies (Scott Wilson Kirkpatrick, 2002), although abstraction in 2004-2005 had increased again, reaching 1050$1700 \mathrm{Mm}^{3}$ (UN-ESCWA and BGR, 2013; Ouda, 2014). More than 90\% of the abstracted water is used for irrigation and the remaining is for domestic and industrial water supply of the town of Tabuk. Figure 2-3 shows a part of irrigation scheme in Tabuk area, Saq aquifer. There are two main agriculture companies located at Tabuk area: TADCO (which covers 350,000 du) and ASTRA (which covers $32000 \mathrm{du}$ ) (UN-ESCWA and BGR, 2013). Both companies are privately owned, the former is dealing only with agriculture, while ASTRA invests in a wide range of sectors that include construction, mining, energy, food and agriculture, healthcare, Industry, etc.. Small farmers are also found in Saudi Arabia but they are working on a very small scale mainly to provide food locally or to their family and animals.

While the aquifer is extensively used for agricultural purposes on the Saudi Arabia side, Jordan has lately discontinued agriculture partially to transfer this groundwater resource to fill the gap in water demand from Jordanian cities. In order to manage the shared aquifer, a Memorandum of Understanding was signed in 2007 between Ministry of Water and Irrigation of Jordan and the Ministry of Water and Electricity of Saudi Arabia prohibiting the construction of production wells and the expansion of agricultural activities within $10 \mathrm{~km}$ from either side of the southern border of the two countries. In 2015 an agreement was also signed between both countries to enforce the prohibition of pumping in a buffer zone (Müller et al., 2017). 


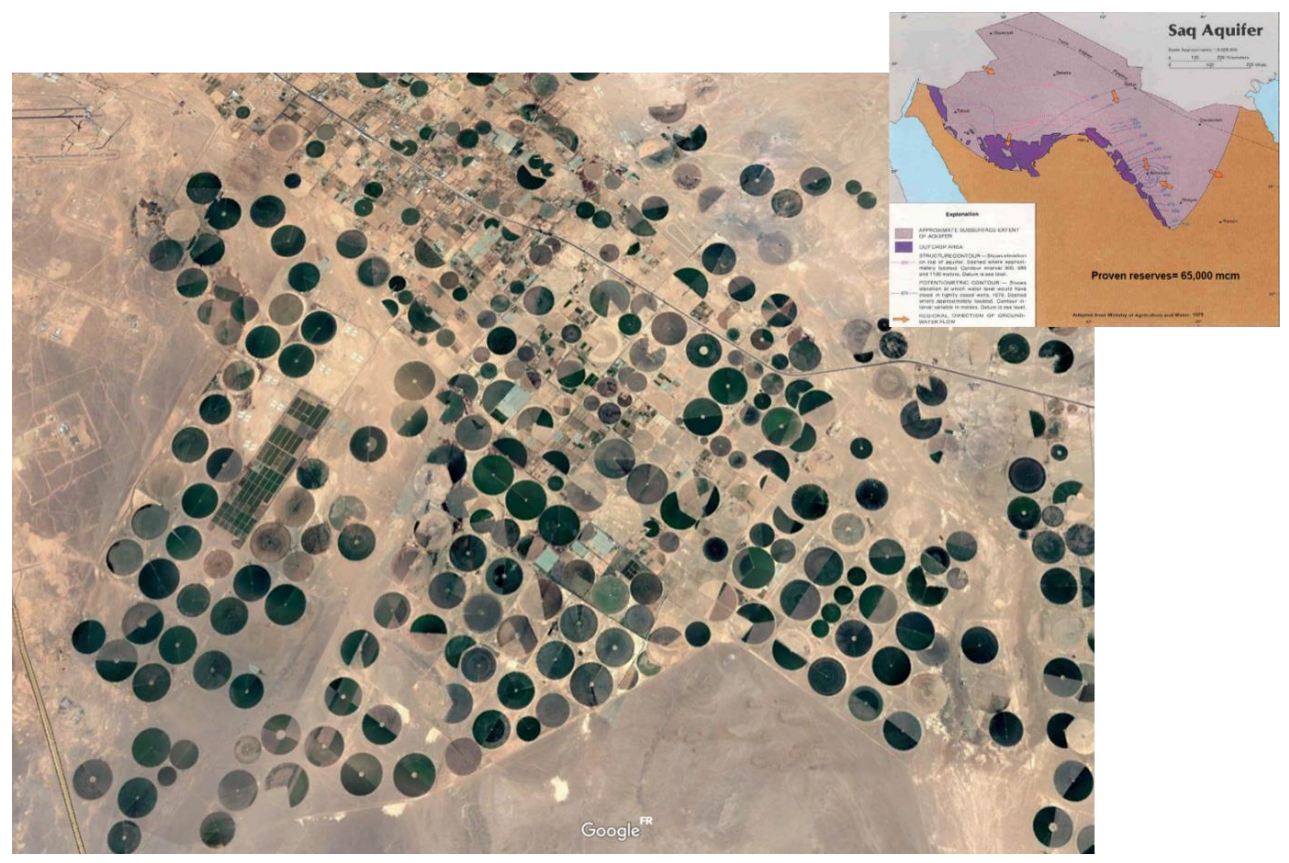

Figure 2-3. Cultivation in Tabuk area (Google Earth and Ministry of Agriculture and Water, Water Atlas of Saudi Arabia 1984)

\subsubsection{Morocco}

In Morocco, groundwater-based agriculture has developed around the oases along the eastern border of the country and in the south, more prominently in the Souss-Massa watershed, which we take here as an example of desert agriculture (Figure 2-4). The SoussMassa watershed is considered as one of the most dynamic and wealthy regions in the country, as it provides most of the Moroccan agricultural exports while covering local food requirements, in addition of its importance for fisheries, tourism and mining activities (Moha et al., 2017). The Souss-Massa watershed covers a surface area of $27,000 \mathrm{~km}^{2}$, with a total population of 2.56 million (RGPH, 2014). The Souss-Massa plain is characterized by a semiarid climatic condition with an average rainfall of less than $200 \mathrm{~mm} / \mathrm{yr}$ and potential evapotranspiration near 2,000 mm/yr (Choukr-Allah et al., 2017). The total water use is approximately $1,034 \mathrm{Mm}^{3} /$ year, where $36 \%$ is from surface water and $64 \%$ extracted from aquifers. $95 \%$ of the total amount is used in agriculture while the rest is drinking and industrial water (ABHSMD, 2007).

The development of groundwater based agriculture in the plain started in the 1940s, after a hydrological study highlighted the presence of aquifers in the area. The cultivated area, estimated at 67000 du in 1950, increased dramatically within 6 years to reach 280,000 du. Lately in 2011, the cultivated agricultural area in the Souss-Massa totaled around 1.6 million du of which 780,224 du are irrigated lands and 820,186 du are rain-fed (Doukkali, 2011). Citrus, cereals and vegetables are the main crops found in the area. $80 \%$ of the farms are considered small with an area less than 50 du (ADA, 2013). Production of citrus and early vegetables in Souss-Massa represents $55 \%$ and $85 \%$ of the national export respectively 


\section{Chapter 2}

(APEFEL, 2014). About one fourth of the regional citrus plantations occurs in the El-Guerdane district $(100,000 \mathrm{du})$, representing over $50 \%$ of the Moroccan citrus production, with the remaining devoted to annual crop cultivation (ADA, 2013). Flood irrigation system is still the most common in the area followed by sprinkler and drip irrigation system (Choukr-Allah et al., 2017).

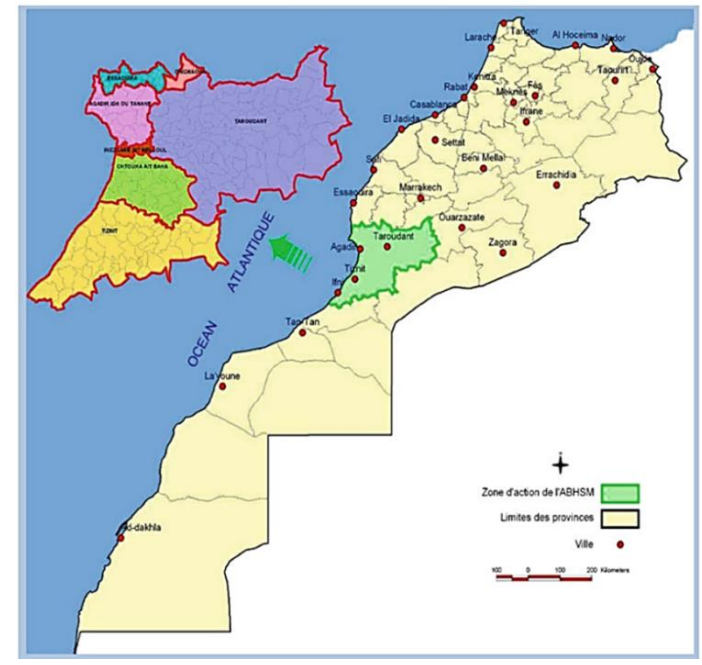

Figure 2-4. Souss Masa aquifer, Morroco (ABHSM, 2005)

Groundwater in the plain is facing deterioration in terms of both quality and quantity (Houdret, 2012; Choukr-Allah et al., 2017; Moha et al., 2017). The Souss-Massa plain experiences a structural average deficit of $270 \mathrm{Mm}^{3} / \mathrm{yr}$ (Closas and Molle, 2016). Water table is declining annually at a rate ranging between 0.5 and $2.5 \mathrm{~m}$ (Choukr-Allah et al., 2017). In the past three decades, water tables decreased by about $15 \mathrm{~m}$ in the upstream Souss basin, by more than $30 \mathrm{~m}$ in the middle Souss, and by $20 \mathrm{~m}$ in the downstream part (ABHSMD, 2007).

Two main projects have been implemented in the plain to face groundwater depletion: ElGuerdane PPP project and Chtouka project (Houdret, 2012; Moha et al., 2017). As mentioned above, El Guerdane supports the country production of citrus fruit. Groundwater depletion affected this cultivation negatively and some farms had to be abandoned. Accordingly, a project for saving the local citrus fruit sector was implemented via a public-private partnership with the aim of decreasing the pressure on groundwater resource and conserving the citrus production by transferring $45 \mathrm{Mm}^{3}$ of surface water yearly from a dam located at a distance of $90 \mathrm{~km}$ to benefit 100,000 du citrus farms (Figure 2-5) (Houdret, 2012). The second initiative is desalination of sea water to provide water for irrigation in Chtouka agricultural area where groundwater levels have dropped by $40 \mathrm{~m}$ over the past 20 years (MAPM, 2012). 


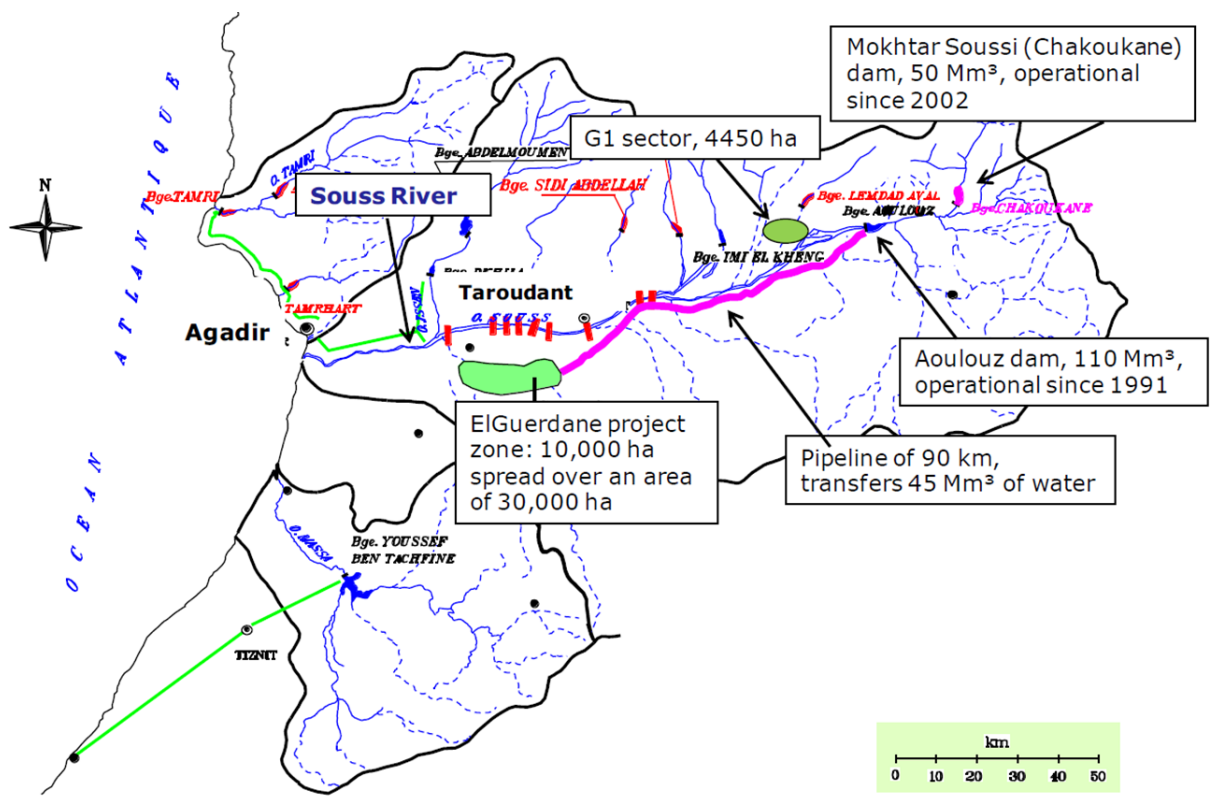

Figure 2-5. El Guerdane project scheme (Houdret, 2012)

In parallel with both initiatives, the government tried to establish a contrat de nappe (aquifer contract) with local users, aiming in particular at freezing the expansion of irrigated areas in certain areas, shifting from gravity to drip irrigation systems, increasing the fees for groundwater user, and regularizing illegal wells (Closas and Molle, 2016).

Guerdane stands out as a large-scale fully groundwater-based agricultural area which qualifies as desert agriculture, as defined earlier. Who is farming in Guerdane? Agribusiness investors, large holders and small farmers are presented in the project area. Most of the farms in Guerdane project are relatively large, with an average size of 160 du. Only 13\% of the farms have an area under $30 \mathrm{du}$ (Houdret and Bonnet, 2013).

\subsubsection{Algeria}

Abstraction of groundwater for agriculture purposes in Algeria occurs in the north via shallow wells and often in conjunction with surface water and rainfall (mainly in Mitidja and Ouarizane), and in the south (Algerian part of the Sahara Desert) using traditional foggaras systems and tubewells. Groundwater basins in the north are renewable while in the south they are largely fossil non-renewable aquifers (some exceptions can be found in western oases and at the southern foot of the Atlas Mountain). Most groundwater basins both in the north and the south are overexploited or being mined, with annual drops in water table by 1 m or more (Imache et al., 2010).

Farming in Algerian Sahara Desert has been promoted by the World Bank, stressing the necessity to diversify the oil-based economy of the country (The North Africa Post, 2013). Agriculture now features as the booming sector in the country, providing more employment than the oil industry. The government encouraged farming in the desert through cheap loans 


\section{Chapter 2}

and concessions to farmers willing to take up the challenge of toiling their farmlands in the desert (The North Africa Post, 2013).

There are several types of farming in the Sahara Desert, from small-holder farming to corporate farming. Desert potato production started in the beginning of the 2000s in El Oued region, south of Algeria (Figure 2-6), mostly taken up by local small holders or migrants with limited investment capacity. This production was successful due to the presence of fossil aquifer water and favorable mild and sunny winter climate (Agroberichten, 2016). The potatoes are cultivated in one-hectare circular fields irrigated by locally developed and adapted center pivots (Agroberichten, 2016). This cultivation made El Oued as the largest potato production area of Algeria with two harvests per year and providing $40 \%$ of the country's production (Potatopro, 2016). Constraints emerged lately, including a decline in the water table, an increase in temperature, plus the lack of efficiency/uniformity of irrigation by locally-made mini-center-pivots which affect production negatively (Agroberichten, 2016).

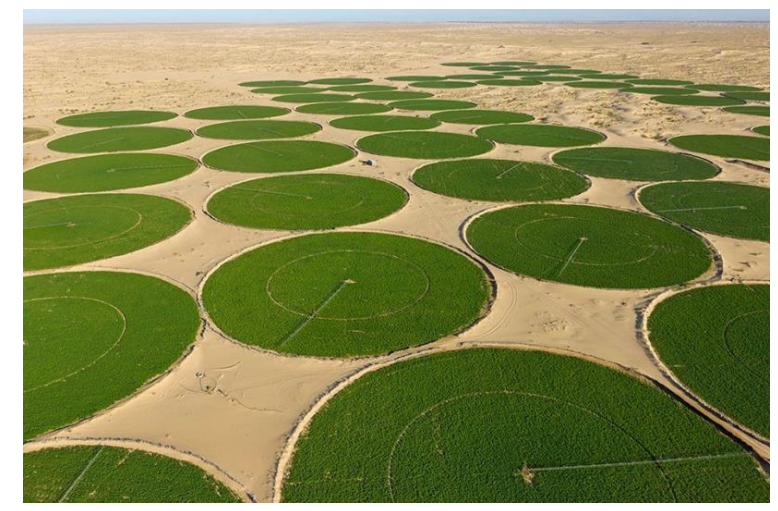

Figure 2-6. Potato fields in El Ouda (Steinmetz, 2015)

The Southern Agri-Food Complex (CAAS) is an example of joint-stock company established by local investors, with the aim to develop 300,000 du in the Adrar region through cultivation of cereals and industrial crops (tomatoes, beets, seed oil), as well as construction of an agrifood complex to produce tomato sauce (Manseur, 2017). During 2003/2004 season, wheat yields exceeded all expectations, and tomato production and processing started in the plant. However, the situation did not last long as a few years later the plant stopped functioning due to lack of raw material. The purchase price of cereals did not make it possible to cover the production costs. In 2007, the production stopped, this failed experience of agribusiness in Algerian desert (Manseur, 2017) echoing that of the 1980s (Bisson, 2003).

Recently, however, farming opportunities have caught the attention of large-scale international investors. New agribusiness Megaprojects are being implemented in the Algerian desert with national and international partnerships. A surface area of 6 million du is reserved for these projects, which will be oriented mainly towards the production of cereals, potatoes and milk (Manseur, 2017). Theoretically, these kinds of projects promise to provide more jobs and to enhance the country's food production. A number of concerns were raised regarding these projects and Manseur (2017) describes them as "harmful and without a future" as there are based on agribusiness models focused on "capitalist and commercial" 
farming without studying the social and environmental impacts. He stresses his concern regarding the future of small-scale farmers and peasant agriculture if the market is to be fully controlled by the megaprojects production. He also raises concerns about the impact of these projects on groundwater resources and the environment, as groundwater is the only source of irrigation in the desert and the aquifers are already partially depleted due to past extraction.

\subsubsection{Egypt}

Land reclamation in Egypt's desert has been a major objective of several governments for more than 50 years (Stack, 2007). Interest in agricultural development in desert land has intensified due to several reasons: a) the increase pressure on food demand due to the increase in population, especially in the Nile Delta area; b) increase in the unemployment rate, especially among the youth; c) the need for new areas to settle people, as $78 \%$ of the population is concentrated in Nile River Valley or along the Mediterranean Sea; and d) to alleviate poverty (Adriansen, 2007; Boctor, 2007; Stack, 2007; Oxford Business Group, 2012). The government encouraged people to move to the new reclaimed lands by offering land to peasants, small business investors and even university graduates who could not find a decent-paying job in the cities (Stack, 2007).

The original 1982 Horizontal Expansion Plan entrusted to the Ministry of Agriculture and Land Reform (MALR) and the Ministry of Water Resources and Irrigation the reclamation of 11.3 million du (9.1 million from Nile water, 1.4 million from deep groundwater and 0.8 million from reuse of treated wastewater). 340,000 du were reclaimed and converted from desert to productive land by the year 1997, when a new Horizontal Expansion Plan was adopted, aiming to develop 14.3 million du. In 2015, a new ambitious plan designed to reclaim 16.8 million du has been announced by the government: the first phase already started with 4.2 million du ('one million feddan') under reclamation in various parts of the western deserts, irrigated mostly from fossil groundwater aquifers. Intense well drilling is taking place and international drilling companies have been invited to supplement local drilling potential (MetaMeta, 2015), but the project is undergoing severe delays.

Abu Minqar is one of the oases in the western desert that has been part of early land reclamation projects based on the drilling of wells in the Nubian Sandstone Aquifer for agriculture purposes in the late 1980s. Before this initiative the area was like "bleak moonscape" as Stack (2007) described it, while now it is a green area cultivated with wheat and lemon trees. The government supported people to relocate there by providing each family with a house and $10-25$ du at minor rate of $35 \$$ to $52 \$$. The area is well served with roads, electricity and network of canals for irrigation (Stack, 2007). Experts, researchers and locals have raised a number of concerns about this project as well as others, as it does impact groundwater quality and quantity (Tutwiler in Stack, 2007), and because the state has failed to build lined canals and provide proper drainage, causing losses by evaporation and infiltration.

While the western deserts/oases are the focus of President's Sisi 'one million feddan' plan, expansion in desert land is also occurring west of the delta, in Wadi El Natrum area where it is possible to tap the Moghra aquifer. The development of groundwater use from the Moghra aquifer has accelerated with reclamation projects that lease land to large and medium-sized agricultural enterprises. Cultivation started in the Wadi el Natrum since 1960s 


\section{Chapter 2}

by small holders' farmers followed by large-scale investors. The cultivated area in 2015 was estimated to be 90,000 feddan $(378,000 \mathrm{du})$, consuming $5000 \mathrm{~m}^{3} /$ feddan annually of groundwater. As groundwater resources in the Moghra aquifer is non-renewable, the sustainability of this resource use is by nature non-existent, but excessive abstraction accelerates the overall depletion of the resource and increases the risk of salinity hazard (MetaMeta, 2015).

Last, two major desert agriculture initiatives can be found in the south of the country. The first is located close to the border with Sudan in the East-Oweinat area, and chiefly includes a series of pivots managed by the army. The second project is that of Toshka, or the New Valley. The project started in 1997 with the purpose of reclaiming 2.26 million du of land. The government hoped to move about six million Egyptian from the Nile Valley to reclaimed land in Toshka (Boctor, 2007). Toshka is located to the west of Lake Nasser and was initially irrigated through groundwater wells, but in 2005 irrigation water was supposed to come from Lake Nasser through a pumping station, known as the world's largest one, and a canal (Oxford Business Group, 2012; Farag, 2003) (Figure 2-7). The station pumps around 14.5 $\mathrm{Mm}^{3} /$ day (Farag, 2003; Boctor, 2007). The farms in Toshka were expected to employ about 60,000 workers (Fulmer, 2000), but here again development has faced many problems and remained a far cry from planned intentions.

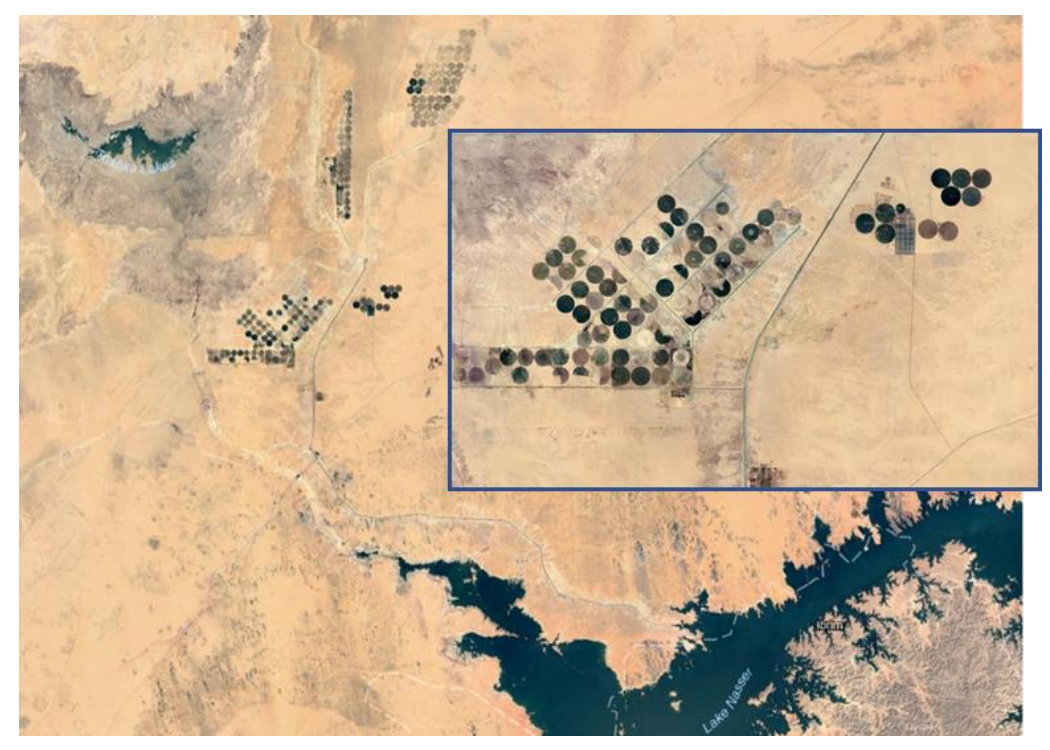

Figure 2-7. Cultivation in Toshka, Egypt (Google Earth)

\subsubsection{Jordan}

Groundwater-based agriculture in Jordan is concentrated in Azraq, Amman Zarqa and Disi basins. Desert agriculture in Azraq basin is the core topic of this thesis and is described in more detail in the coming chapters. I briefly refer here to the cultivation in Rum and Mudawwara region located in the southern part of the country and irrigated from the transboundary Disi aquifer. The total population of these areas is 250,000 inhabitants. Jordan 
started using the Disi aquifer groundwater since 1977, with an average rate of $5.4 \mathrm{Mm}^{3} / \mathrm{yr}$ and the water was used for various purposes including agriculture (Abu-Ajamieh et al., 1988). In the beginning of 2000 extraction reached $70 \mathrm{Mm}^{3} / \mathrm{yr}$, of which $55 \mathrm{Mm}^{3}$ to agriculture sector (Barthelemy et al., 2010). According to the Ministry of Water and Irrigation reports, the average annual abstraction rate was reduced in 2009 to $65 \mathrm{Mm}^{3} / \mathrm{yr}$, including $40 \mathrm{Mm}^{3} / \mathrm{yr}$ for desert farming (MWI, 2009; 2011).

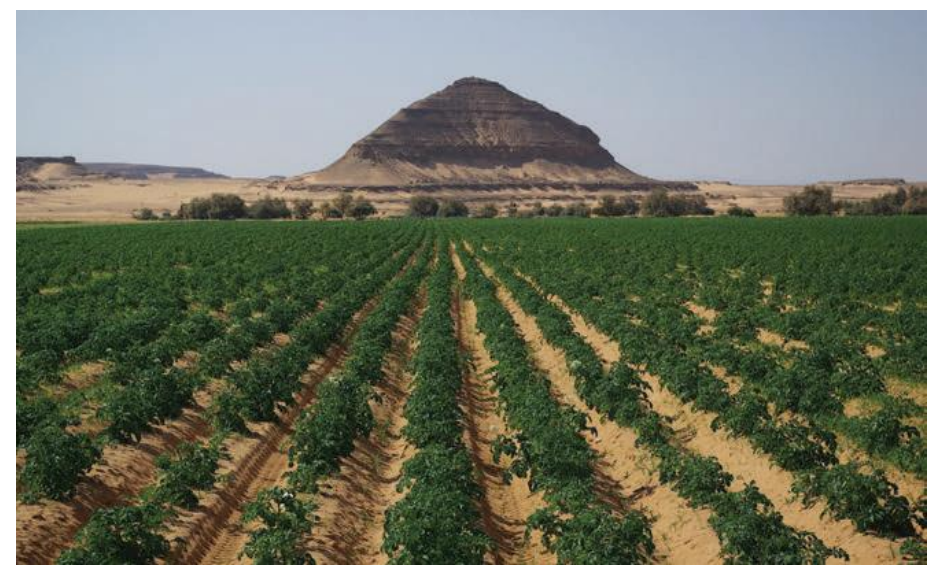

Figure 2-8. Cultivation in Wadi Rum operates by farmers small cooperatives and big farms companies (Photo credit; Andreas Renck, 2009).

The government encouraged farming in southern deserts by giving licenses for 25 years (starting in 1980) to five agriculture farming companies: Rum Company (50,000 du), WAFA Farm (14,480 du), ARICAT Farm (21,150 du), Jordan Financing House Co. (14,810 du) and GRAMCO Farm (16,380 du), bringing the total licensed area to 116,760 du (Barthelemy et al., 2010). Figure 2-8 shows an example of cultivation in Wadi Rum. As the Jordanian government planned to transfer water from Disi aquifer to Amman for drinking purposes, it started not renewing the contracts with the above-mentioned agriculture companies, which -after some court case- had to discontinue their operations. The Disi-Amman Water Conveyance Project started in 2014 extracting about $100 \mathrm{Mm}^{3} / \mathrm{yr}$ and raising total abstraction in the basin to around $146 \mathrm{Mm}^{3} / \mathrm{yr}$ (Molle et al., 2017a). Small farmer cooperatives are still functioning in the area but on a very small scale. Raising groundwater abstraction resulted in a drop in the water table from the mid-1980s onward (Margane, 2011).

\subsubsection{Key production factors}

It stands to reason that mobilizing the production factors associated with agricultural activities (land, water, labor, input, capital) may come with specific difficulties when farming desert land. We briefly review here how these difficulties have been dealt with in the case of some of the countries selected and introduced above and also in some countries outside the selected examples in the above section. The researcher will come back to this issue in the synthesis chapter, comparing the findings on Azraq with these other countries. 


\section{Chapter 2}

\subsubsection{Land}

Desert lands, at first sight, are of little value. But the necessity of urban expansion and potential economic opportunities from utilizing lands in different ways fuel the expansion of human settlements in these often-neglected areas in the MENA region. The expansion of human settlements in desert lands can be either state-driven or private-initiative-driven (with or without state permission). Many states in the MENA region have supported the expansion of settlements in the desert through land reclamation projects, encouraging the population to relocate by providing subsidies to buy lands with low price or for agricultural equipment, and sometime by land reforms, distributing land to peasants, young jobless universities graduates, investors or large companies (illustrated in Chapter 5). Expansion through private initiative includes initiatives by both small farmers (e.g. along the Nile Valley and Delta, or Souss region) or corporate firms of all size. Such initiative can be fully illegal (but tolerated), thrive on religious/traditional/legal disposition allowing desert to be reclaimed and ownership of land later claimed ('wadaa el yad' principle), or mediated by the government (with conditions for obtaining licenses often linked to wealth, influence and power).

Desert areas suitable for agriculture due to the presence of groundwater are normally located in areas where the local population is limited and often confined to herders, either settled or transhumant, who exploit the badia (steppe), a land where extensive grazing is possible but not agriculture. Land is generally held under customary law, often collectively. In the Arab world, uncultivated lands have often been formally put under state ownership during the time of nationalist, Baath, or socialist post-WWII experiences. That is in particular the case in Iraq, Syria, Jordan, Egypt, Libya or Algeria. As this land became locally valuable, the state sought to redistribute it under different modalities, both to small farmers or urban youth and to investors/companies.

Hereby a general description about land tenure in some selected countries of MENA region where desert agriculture occurs. In the case of Morocco, although there are cases of claims by local Berber tribes or otherwise over state irrigation project areas (like in the Gharb scheme, for example), expansion is either done by smallholders expanding into adjacent lands or by investors/outsiders. In that case these investors will secure land titles but the situation varies widely depending on the tenure status of the land. Morocco is known for its complex land regime, with categories of collective lands in particular, but there is growing commercialization of land under traditional tenures (see Molle and Tanouti, 2017). In the Souss-Massa, investors secure deeds from the government or rent collective land and tenure security is usually not seen as a major problem.

In Algeria, desert land development programs have started since 1983 with the aim to develop and reclaim these neglected areas. Accordingly, public land access was simplified to land users, important public investments in infrastructure (roads, electrification, and collective boreholes) and direct farmers subsidies were granted (Ben Hounet et al., 2011; Daoudi and Colin, 2016). Consequently, desert lands witnessed the arrival of new farmers coming from the northern part of Algeria, agriculture was intensified mainly with vegetables, increase of informal sale of land and lease on the land market were noticed (Daoudi and Colin, 2016).

In Egypt, as mentioned in the above section (2.2.1.4), expanding agriculture in the desert through land reclamation projects has been on the political agenda since the 1950s and used 
as a remedy for a variety of problems like desertification, poverty, and reduction of graduate unemployment. The idea was first implemented by El Nasser in the 1950s through a plan labelled the 'Five Feddan ${ }^{1}$ Scheme' (Johnson, 2004), and this idea continued throughout the Mubarak era (Adriansen, 2009), until its last embodiment in President Sisi's 'one millionfeddan Plan'. The importance of land reclamation project comes with the increase in population and the needs to expand horizontally and provide more economic opportunities and food by utilizing desert land through the development of new water resources (mainly groundwater) for irrigation and other beneficial uses (Taylor, 1976; Allan, 2001).

Egypt is notable for the diversity of actors who have been allowed to acquire land in State land reclamation projects, including small farmers, land less farmers, graduates, investors of all sizes, big corporate or public companies, and even the army (Sims, 2015; Adriansen, 2009). Officially, all desert land in Egypt belongs to the state, since 1820-30 (Rae, 2002). Yet, like in many other places of the Arab world, it is often claimed by Bedouin tribes especially when the land is part of traditional grazing lands used by these tribes. Formally excluded from land they consider as theirs, Bedouins therefore resort to illegal ways to extract a benefit from the land mobilized by the state for its reclamation projects. In the Nubaria area, for example, cooperatives of settlers of state projects, have to pay annual 'fees' to local Bedouins, officially in charge of 'security' (Molle, pers. com. 2016), although they reportedly do little and even sometimes get involved in theft of electric wires or transformers (ibid.). Dixon (2017) report that investors who owning lands located to the west of the delta, has to pay some 'compensation money' to Bedouins. In desert areas where investors have moved, either with limited state planning and intervention (e.g. the Wadi el Natrun area, see MetaMeta, 2015) or illegally, outside of any formal scheme (e.g. areas south of Nubaria canal and recently the Sadat City reserved perimeter, see Abe, 2015 and Hamid, 2016), Bedouins are reportedly exacting payment for settlers for 'protection' and only powerful persons with their own armed guards escape this practice (Molle, pers. com. 2016). Accessing land is therefore potentially problematic and/or with a cost, but this cost is still limited compared with expected gains from agriculture, and even more so from speculative purposes where this applies.

Land tenure in Jordan is well illustrated in brief in Chapter 5. Outside of the selected countries examples in the above section, it was found that in Tunisia, the revolution in groundwater use unfolded in parallel with the land reform in the beginning of 1970s, as the state nationalized the land that was owned by the French (Closas et al., 2017). This nationalization gave Tunisian farmers more space and more water to cultivate (Geroudet and INA, 2004) as access to and abstraction of ground water were linked to land property and land access (Closas et al., 2017). In the beginning of 1970s land was allocated to private owners via decree and in some cases via property titles (Closas and Molle, 2016). Closas and Molle (2016) indicated that "in many cases land division was not done officially and families organized their own land plotting and allocation via inheritance and not official allocation."

We have noted how government involvement helped in expanding groundwater based agriculture in MENA region through land reforms and land distribution or lease. But 'empty lands' in the MENA region are not under absolute control from government; there are

\footnotetext{
${ }^{1} 1$ Feddan $=0.42 \mathrm{ha}, 4.2 \mathrm{du}$
} 


\section{Chapter 2}

different laws defining land uses, ownership and how to obtain lands but in practice land management is more complex and faces situations of legal pluralism.

\subsubsection{Water}

The availability of water in desert land, and the possibility to develop agriculture, depends on groundwater. The availability of groundwater generally leads to the formation of oases as water occurs through springs, shallow aquifers tapped by wells or qanats, or deep (generally fossil) aquifers that are tapped through tube wells. Availability depends on both physical and legal factors.

In terms of physical availability, groundwater in the desert may be available under artesian conditions, like in parts of the Egyptian or Algerian desert; be rather shallow, like initially around the Azraq wetland where it could be accessed through shallow dug wells, or in parts of Algeria where palm trees are grown in small depressions that allow them to access groundwater; or be very deep, like in Mafraq, Jordan where it can be at $350 \mathrm{~m}$ or in Liwa, Abu Dhabi at average depth of $260 \mathrm{~m}$ (Fragaszy and McDonnald, 2016). It is often little no nonrenewable. Of course, these differences result in contrasting abstraction costs, which make agriculture - or specific crops - more or less profitable and therefore attractive.

But access to water is also in general regulated by state laws. Just like for land, post-WWII regimes in the MENA region put the custodianship of water resources under the state, which through laws and decrees regulate and allocate groundwater resources. Several typical measures introduced by states are shown in Table 2-1 (Faysse et al., 2011; Closas and Molle, 2016). Wells are controlled using various means: through permits (case of Algeria, Morocco, Jordan), well spacing (case of Jordan and Lebanon), announce prohibition zone, wells backfilled (case of Jordan), water tariff (case of Jordan and Syria), metering system (case of Jordan, Morocco (but not applied) and Syria), controlling the irrigated area expansion (case of Jordan) and also through capacity building and social learning (Faysse et al., 2011; Closas and Molle, 2016).

In Saudi Arabia, the ministry of agriculture and water is responsible of controlling and management of groundwater resources. In 2001, the ministry has adopted several regulations to control groundwater abstraction such as permits for well drilling and the supervision of drilling activities (Burchi and D'Andrea, 2003). These regulations were applied to farmers whose land exceeded $25 \mathrm{du}$ (ibid.). Well drilling is banned in over-pumped areas or in areas where aquifers suffer from declined in water level, and penalties were sit to unlicensed drilling companies as well as well owners without permits (ibid.). In Saudi Arabia, water for agriculture is not priced and once the well has been drilled, the owner has the right to abstract water at his own cost without tariffs being collected by the water authorities.

In Morocco, abstraction permits are needed for wells deeper than $40 \mathrm{~m}$ and extraction charges have been defined for each type of water use (Adnane, 1989; Del Vecchio, 2013). The abstraction permits are given under certain conditions specifying the allowable abstraction volume of groundwater, the maximum discharge per hour, the depth of the well, purpose of abstraction, and the area to be irrigated in the case of agriculture. The request of a well permit must contain a map of the land plot indicating the position of the well, the official land deed, a feasibility study of the project showing the impact of abstraction on water resources, cultivable lands and aquatic ecosystems (the latter is not mentioned in the 
official form provided for permits requests). The law also specifies pumping tests to be carried out and minimum distances between wells to be respected (Closas and Molle, 2016). But in reality farmers manipulate the law in several ways. Some have benefitted from the well regularization process opened by the government to legalize old wells by declaring recently drilled wells as 'old' and turning them legal (BRLI and Agro-Concept, 2012). Others apply for well maintenance permit (deepening), or apply for wells to be used for domestic proposes or livestock use, while using them for irrigation instead (Closas and Molle, 2016). The ministry of Agriculture actually offered several ways to bypass the control of River basin Agencies so that farmers could drill wells and apply for micro-irrigation projects (BRL and Agro-Concept, 2012; Closas and Molle, 2016; Molle, 2017). Wells meters are not being installed and groundwater use in agriculture is not charged.

In Algeria, the monitoring and management of groundwater resources at national level is under the authority of Ministry of Water Resources (Benblidia et al., 2011). Based on Water Law 05-12 of 2005, the local governor is in charge of regulating wells through the granting of permits (Imache, 2014). The 2005 Water law introduced the establishment of protection areas where new wells should be banned and active ones should have an abstraction limit in order to protect drinking water supply (Algérie, 2005). Imache (2014) mentions that meters are only applied for state-owned wells that supply water for drinking. As in Morocco, the request for a well permit should include a land map with the well location, pumping test, use purpose, project technical documents, duration and abstracted amount (Closas and Molle, 2016). Closas and Molle (2016), based on Bellal et al.'s (2015) review, observe that "water use in agriculture remains a blind spot to which authorities have turned a blind eye, ignoring existing laws". Bellal et al. (2015) also note that the control of water is an elusive goal since most of agriculture wells in Algeria are not even registered. In other words, accessing water is not so much a legal or regulatory problem and the government is still keen to promote agriculture in the desert, where groundwater regulation has not yet become a subject of concern. The constraint, rather, is the cost of pumping -in some areas only-and the need to preferably be connected to the electricity grid.

In Egypt, the Ministry of Irrigation is responsible for groundwater use and permits through the Irrigation and Drainage Law of 1984. Based on the law, all wells need to be permitted regardless of their depth. The extraction permit is theoretically renewed every 3 years and lasts for 10 years. In case the pump is replaced a new request must be made. Applications requires many documents (land deed, maps with the location of the well, all neighboring wells (legal or otherwise) and their distance to the projected well, soil sample analysis, commitment to use the wells with the discharge and type of irrigation technology indicated, payment of fees, etc ${ }^{2}$ ), which explains why few farmers bother declaring their wells. A new groundwater law under drafting aims at tightening control over groundwater development through stricter licensing, registration of drilling contractors, monitoring and protection of groundwater abstraction, identification of violations and applied penalties, and application of metering system (El Arabi and Dawoud, 2012).

Water policy in Jordan is well illustrated in brief in Chapter 6. Outside of the selected countries examples in the above section, it was found that, in Tunisia, the authority for groundwater and user right management is under the umbrella of the Ministry of Agriculture

${ }^{2}$ http://gis.nacse.org/rewab/docs/Law 121984 Irrigation and Drainage en.pdf 


\section{Chapter 2}

and the 1975 water law (Closas and Molle, 2016). Groundwater users who have wells deeper than $50 \mathrm{~m}$ are required to obtain an authorization for water abstraction (Bachta et al., 2005). The procedure to obtain authorization goes through the Regional Commissions for Agricultural Development (CRDA). The application should contain an official land deed and an official technical report from a private company authorized by the CRDA. The CRDAs study the application and evaluate whether the use will affect groundwater negatively, and give their recommendation to the Ministry of agriculture. When the authorization is approved, farmers have the right to use the water in any mean as long as it is for agricultural purpose (Closas and Molle, 2016). Licenses are supposed to be renewed on a yearly basis, which makes farmers not willing to apply in the first place (Closas and Molle, 2016). In order to protect sensitive areas with groundwater aquifers, the Ministry can declare prohibition areas where drilling wells is banned and abstraction by existing wells limited by quotas (Closas and Molle, 2016).

The country is encouraging groundwater based agriculture through subsidies on well drilling, new irrigation technique, pumps, piped networks, and energy with an objective of expanding livelihoods opportunities in the countryside. However, there is a lack of law enforcement, the number of illegal wells is increasing, metering systems are not installed, abstraction is occurring in prohibited areas, while Gaubi (2008) describes the current water law as "insufficient to provide a legal framework for a strategy of integrated groundwater use".

In Lebanon, a depth limit of $150 \mathrm{~m}$ above which wells need to be licenses has prevailed for almost one century (Molle et al., 2017b). Under this limit well owners should submit a declaration and receive a receipt specifying the number, the date of registration of the application and location of prospection (ibid.). Wells with a productivity over $100 \mathrm{~m}^{3}$ /day should pay an annual fee (ibid.). These fees have been gradually increasing over the years and are set now at USD 333/year (500,000 L.L/yr) for the drilling fee, USD 0.066/ $\mathrm{m}^{3}$ (100 L.L/m $/ \mathrm{m}^{3}$ ) for irrigation use and USD $0.4 / \mathrm{m}^{3}\left(600 \mathrm{L.L} / \mathrm{m}^{3}\right.$ ) for industrial use (Molle et al., 2017b). In 2010, a new Decision (No.118) was issued by the Ministry for Electricity and Water which established a system of registration through private companies which have the responsibility for the technical aspects of permit application, field visits and well meter installation (Molle et al., 2017b). But the process costs US\$ 935 per application and it is therefore no surprise that no agricultural well owner has applied for a license, nor regularized existing well (ibid.).

In Syria, groundwater abstraction permits were introduced in 1973 (article 10 of law 3) (Saade- Sbeih, 2011). Further legislation was issued in 1999 (Circulaire No.13, 31/08/1999) to regulate groundwater abstraction limiting well with depths to $150 \mathrm{~m}$, and permits granted for either 1 to 3 years or 10 years. The ministry of irrigation is responsible for well permits. In 1999, the government banned new wells and the renewal of licenses for dried-up wells In 2000/01 it decreed the installation of meters, the indication of a maximum allowable abstraction volume, while wells without permits were subjected to fines (Stephan, 2007). But despite these decisions, $57 \%$ of wells are still unlicensed and wells continue to be drilled without permits (Saade-Sbeih, 2011; de Châtel, 2014), like in Salamieh area, where $80 \%$ of wells are without permit (Saade-Sbeih, 2011). The government requires well licenses to be renewed annually but, according to de Châtel (2014: 12), "this engendered widespread corruption as security personnel or officials forced farmers to pay bribes for new licenses, which in turn triggered strong resentment in rural areas." 


\subsubsection{Labor}

Labor is, expectedly, a constraint to large-scale corporate agriculture in the desert, even though technology helps reducing the need for labor. In Egypt, the experience in Toshka was undermined by the difficulty in attracting people to areas with little infrastructure and very harsh climatic conditions (Oxford Business Group, 2012). The Army, in East Oweinat and other places, can count on drafted labor. Even in state-sponsored land reclamation schemes close to the delta it took many years for people to permanently settle, and many gave up and returned to their village in the Valley or the Delta (Adriansen, 2009).

In Jordan, the agriculture sector is minimal and Bedouins often not keen to take up agricultural activities (although some do). Urban investors and other absentee owners would not be able to find Jordanian laborers willing to live in isolate and harsh conditions for a modest salary. Just like in the Gulf, the solution found was to 'import' foreign laborers (mostly from Egypt but also from Yemen or a few other countries), who would accept such working conditions. As we will see in Chapter 7, the right to use such foreign laborer was abused and generated a rent for those taking up agricultural activities.

In Algeria or Morocco there is little reporting of labor problems and they do not seem to constitute a major obstacle to investments in desert farming. The reservoir of jobless people within a country or in neighboring ones is sufficient for solutions to be found.

Agricultural laborers in Saudi Arabia are generally foreigners who enter the country through permits from the Ministry of Work and Social Security, and are controlled by agricultural cooperatives (Arabian Business, 2016).

\subsubsection{Input incentives}

In the MENA region it is hard to find a state that does not encourage agriculture in one way or another. In almost every country several government policies directly or indirectly give incentives to farming. The incentives come in the form of barriers to import, domestic price support, subsidized credit and energy subsidies (World Bank, 2007). Table 2-2 shows where these incentives and in which countries they apply.

Table 2-2. Incentives for irrigation (World Bank, 2007)

\begin{tabular}{|l|l|l|l|l|}
\hline Country & $\begin{array}{l}\text { Barriers to } \\
\text { imports }\end{array}$ & $\begin{array}{l}\text { Domestic price } \\
\text { support }\end{array}$ & Subsidized credit & Energy subsidies \\
\hline Algeria & Yes & Yes & Yes & Yes \\
\hline Bahrain & No & No & Yes & Yes \\
\hline Egypt & Yes & Yes & Yes & Yes \\
\hline Jordan & Yes & Yes & Yes & Yes \\
\hline Lebanon & Yes & Yes & No & Yes \\
\hline Libya & Yes & Yes & Yes & Yes \\
\hline Morocco & Yes & Yes & No & No \\
\hline Saudi Arabia & Yes & Yes & Yes & Yes \\
\hline Syria & Yes & Yes & Yes & Yes \\
\hline Tunis & Yes & Yes & Yes & No \\
\hline Yemen & Yes & Yes & Yes & Yes \\
\hline
\end{tabular}




\section{Chapter 2}

There is also hardly an agricultural policy that does not promote or subsidize micro-irrigation as a key to achieve irrigation efficiency and/or poverty alleviation (Molle, 2017). In Morocco, the subsidies on micro irrigation techniques started at $17 \%$ in 1990 , were raised to $30-40 \%$ in 2002, and 60\% in 2006. With the National Program for Water Savings in Irrigation (PNEEI) subsidizes for micro irrigation finally reached $80 \%$ for large farms and 100\% for farms under 5 ha (Molle, 2017). In Algeria, subsidies for micro irrigation techniques adaptation reached $100 \%$ (Amichi et al., 2015). In Tunisia, subsidies were offered to farmers of $40-60 \%$ of the total investment cost for water saving irrigation technologies (Frija et al., 2014).

The expansion in groundwater-based agriculture in Syria was mainly encouraged by government input subsidizes such as diesel fuel subsidy and crop procurement price support (Aw- Hassan et al., 2014; Gül et al., 2005). Aw-Hassan et al. (2014) and Gül et al. (2005) found that subsidies amounted to around 80 percent of the local purchase price. In 2008, Syria canceled these subsidies on diesel and fertilizers, shifting diesel prices from 7 Syrian pounds to 25 pounds/liter (Saade-Sbeih, 2011). This situation caused many farmers to either depend on rainfed agriculture or to stop agriculture (de Châtel, 2014).

In Yemen, establishing barriers to fruits import to the country caused a large increase in groundwater-based fruit cultivation (Closas and Molle, 2016). Subsidies provided to the private sector to import pumps, engines and well rigs, enhanced well drilling in the country (World Bank, 2001). Yemen' Cooperative and Agricultural Credit Bank provided loans at subsidized rates for irrigation and diesel and electricity prices (Handley, 2000; Hellegers et al., 2008). The subsidy on fuel reached $22 \%$ of all government expenditures (World Bank, 2001 and van Steenbergen, 2015).

In other words, what these examples show is that most governments tried, and with some exceptions like Jordan are still trying, in different ways to encourage agriculture in general, and groundwater-based farming in particular. Making machinery, energy, and agrochemical more affordable, while sometimes establishing protected markets, helped make this activity profitable. Whether forced by the World Bank or the International Monetary Fund (e.g. Syria, Yemen) or because of changes in policy thinking (Saudi Arabia), things have started to change in a few countries.

The energy source for groundwater based agriculture in the past was mainly diesel. Farmers started to shift to electricity based pump instead of fuel as it is cleaner, cheaper (but also subsidized), and appropriate for submerged pumps in tubewells. In many countries (e.g. Jordan, Tunisia) land and wells should be legal in order to get the benefit of using the public electricity grid. Recently, farmers have started adopting solar energy system (e.g. Jordan, Algeria, Morocco), which takes energy prices down.

Fertilizer and pesticides are generally controlled by private firms and it is hard to do a comparison as their prices vary from company to company, and from country to country. In general, the relative isolation of desert agriculture works to increase transportation costs. However, it must be noted that in many cases this activity is (very) profitable and therefore largely covers the costs of input factors other than water. 


\subsubsection{Capital}

Engaging in groundwater-based agriculture generally needs important amounts of capital in order to buy land, drill wells, obtain licenses, and install irrigation systems.

However, this is not always the case. In Algeria, for example, public land is distributed at a very low cost, drilling wells is largely subsidized, and in some parts water even comes under artesian conditions. Investors of all types and size can start farming with relatively limited capital. This also applies to parts of Morocco when collective lands can be negotiated and leased at a rather low price, and where agriculture is receiving tax exemption. 

CHAPTER THREE

Case Study Description: Azraq Basin, Jordan 



\section{Chapter Three: Case Study Description: Azraq Basin, Jordan}

\subsection{Case study description: Azraq basin}

\subsubsection{Physical and social setting}

This section presents the main physical and human features of the Azraq basin, together with the status of agriculture and groundwater use. Some of these background data are briefly referred to in the different papers for the sake of - each time - introducing the readers to the context of the case study, but the researcher provides here a more detailed description.

\subsubsection{Geographical location}

Jordan has twelve groundwater basins (Figure 3-1) and fifteen surface water basins (Figure 3-2). Some basins are fully located inside the country boundaries while some are partially shared and managed with neighboring countries. Ten out of the twelve-groundwater basins are considered renewable while two are largely non-renewable basins: Jafer and Disi.

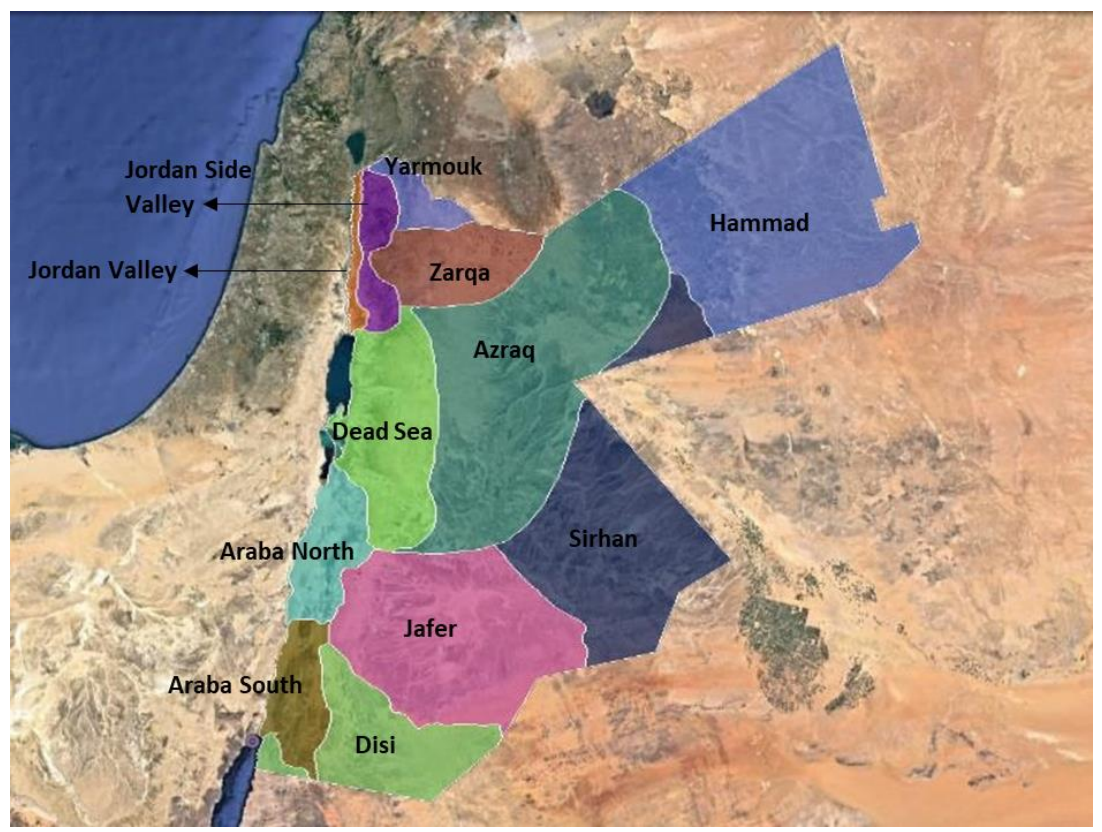

Figure 3-1. Groundwater basins in Jordan (Royal Jordan Geographic Center, modified by the author)

Table 3-1 shows groundwater basins' status and safe yield. As it appears, Amman-Zarqa basin followed by Azraq basin, are the most over-abstracted basins in the country with balance of 66 and $-27.6 \mathrm{Mm}^{3} / \mathrm{yr}$ respectively. These data, however, are based on official abstraction values that have been shown to be underestimated (Molle et al., 2017a), which means that actual rates of over-abstraction are likely to be higher. 


\section{Chapter 3}

Table 3-1. Groundwater basins usage, safe yield and balance (MWI, 2009; Molle et al., 2017a)

\begin{tabular}{|l|l|l|l|l|l|l|l|l|}
\hline $\begin{array}{l}\text { Groundwater } \\
\text { basin }\end{array}$ & $\begin{array}{l}\text { Safe yield } \\
\left(\mathrm{Mm}^{3} / \mathrm{yr}\right)\end{array}$ & \multicolumn{2}{l|}{$\begin{array}{l}\text { Total extraction } \\
\left(\mathrm{Mm}^{3} / \mathrm{yr}\right)\end{array}$} & \multicolumn{2}{l|}{$\begin{array}{l}\left.\text { Balance (Mm }{ }^{3} / \mathrm{yr}\right) \\
\text { \% of safe yield } \\
\text { abstracted }\end{array}$} & $\begin{array}{l}\text { No of } \\
\text { wells }\end{array}$ \\
\hline & & $\begin{array}{l}\mathrm{MWI}, \\
2009\end{array}$ & $\begin{array}{l}\text { Molle et } \\
\text { al., 2017a }\end{array}$ & $\begin{array}{l}\text { MWI, } \\
2009\end{array}$ & $\begin{array}{l}\text { Molle et } \\
\text { al., 2017a }\end{array}$ & $\begin{array}{l}\text { MWI, } \\
2009\end{array}$ & $\begin{array}{l}\text { Molle et } \\
\text { al, 2017a }\end{array}$ & $\begin{array}{l}\text { Molle et } \\
\text { al., 2017a }\end{array}$ \\
\hline Yarmouk & 40 & 55 & 54.16 & -15 & -14.16 & 137 & 135 & 203 \\
\hline $\begin{array}{l}\text { Jordan Valley } \\
\text { Side Wadis }\end{array}$ & 15 & 12 & 46.73 & 3 & -31.73 & 80 & 312 & 139 \\
\hline Jordan Valley & 21 & 38 & 17.02 & -17 & 3.98 & 181 & 81 & 334 \\
\hline Amman Zarqa & 87 & 153 & 166.11 & -66 & -78.61 & 176 & 190 & 955 \\
\hline Dead Sea & 57 & 85 & 89.98 & -28 & -32.98 & 149 & 158 & 469 \\
\hline Araba North & 4 & 4 & 6.33 & 0 & -2.83 & 100 & 181 & 37 \\
\hline Araba South & 6 & 5 & 8.48 & 1 & -2.98 & 83 & 154 & 62 \\
\hline Jafer & 9 & 23 & 32.85 & -14 & -21.85 & 256 & 365 & 205 \\
\hline Azraq & 24 & 51.6 & 52.54 & -27.6 & -28.54 & 215 & 219 & 580 \\
\hline Sirhan & 5 & 1.5 & 1.71 & 3.5 & 3.29 & 30 & 34 & 23 \\
\hline Hammad & 8 & 1.3 & 1.87 & 6.7 & 6.13 & 16 & 23 & 15 \\
\hline Disi & Fossil & 65 & 146.96 & & & & 118 & 116 \\
\hline
\end{tabular}

This study focuses on the Azraq basin, a perfect illustration of desert agriculture in Jordan. Azraq consists of two basins; groundwater basin and surface water basin. The areas considered in this thesis are located in the central and northern part of the surface basin (Figure 3-2). The basin total area is $12,710 \mathrm{~km}^{2}$, with $94 \%$ of it located in Jordan, $5 \%$ in Syria and $1 \%$ in Saudi Arabia (Shahbaz and Sunna, 2000; Addamat et al., 2006; Halah, 2007; Al Raggad and Jasem, 2010).

Within Jordan's territory, Azraq basin overlaps with three Jordanian governorates: Zarqa governorate represented by Azraq district; Mafraq governorate represented mainly by a part of North Badia district; and Amman Capital governorate represented mainly by a part of Al Jiza district (DoS, 2008). This study covers the area of Azraq district and part of North Badia ('Mafraq' in what follows). Azraq district includes eight sub-districts: South Azraq; North Azraq; Omari; Ein Al Baida; Eastern Farms area; Um Al Mathayel; Deghaila; and the air force base (Figure 3-3). The total population in the Azraq Basin area reached about 29,000 in 2010 (DoS, 2010), while the total population of the district was around 12,000 (IUCN et al., 2007). 


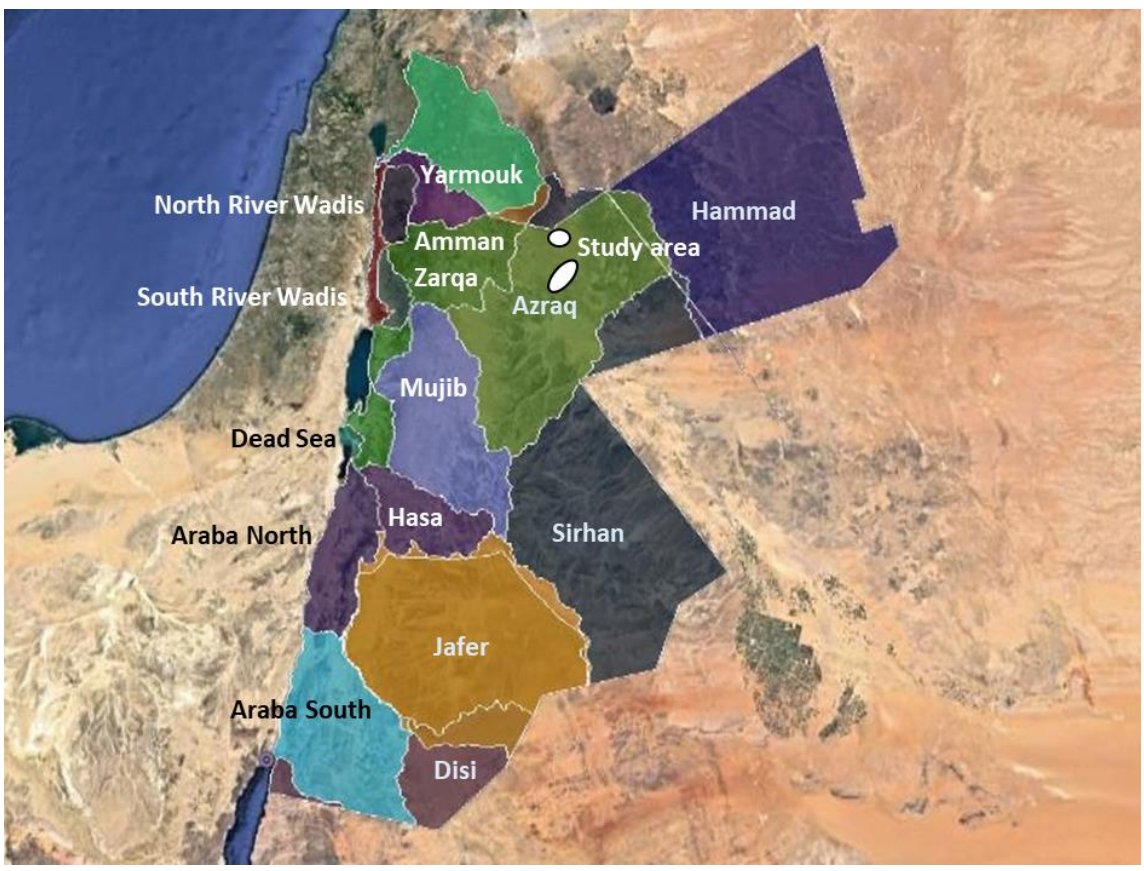

Figure 3-2. Surface water basins in Jordan with study area location (Royal Jordan Geographic Center, modified by the author

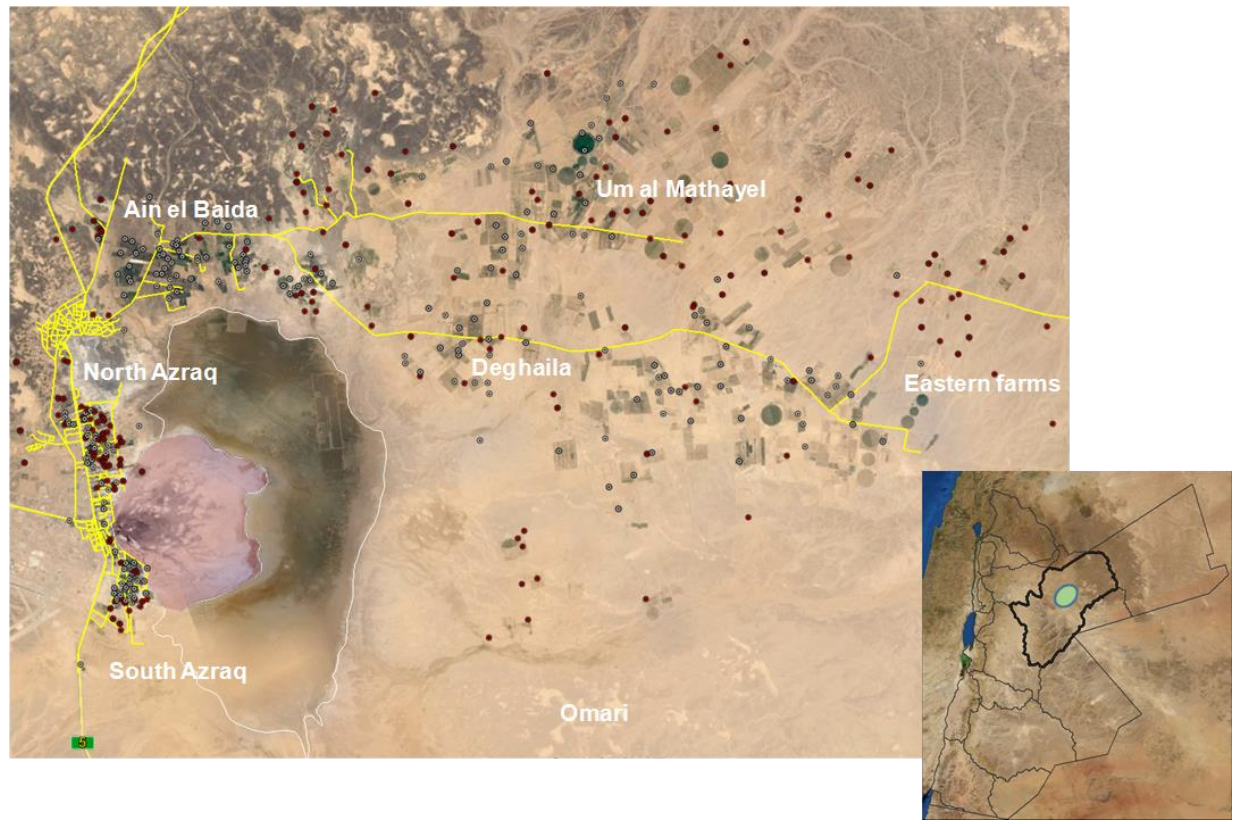

Figure 3-3. Azraq district areas (Google Earth, modified by the author) 


\subsubsection{Community}

Azraq community is made up of three main ethnic groups: Bedouins, Chechens and Druze. As mentioned above, Azraq has 12,000 inhabitants, with 6500 for the Druze located mainly in North Azraq area, with a minority of Bedouins. South Azraq is home to approximately 4000 inhabitants, mainly Chechens and Bedouins. Minor settlements can be found in the area of Ain-Al-Baida and the farm area, with 500 inhabitants, most of them from the Ahel Al-Jabal tribe. 350 inhabitants are settled in the military airbase and 400 in the Al-Omari area in addition to some families in the Um Al- Mathayel and Deghala areas (Mesnil and Habjoka, 2012).

Bedouins are spread all over the country as they traditionally have a semi to fully nomadic life style, moving from place to another according to the season (HCST, 1993). Today, Bedouins tend to settle in cities or on what they consider as their tribal lands, and are spread over the country as follows: in the North, Bani Hasan, Bani Khalid, Sardiyyah, Sarhan, 'Isa, Ahl al-Jabal consists of four large clans: Masa'id, Shurafat, 'Athamat and the Zbaid, a small portion of the great Rualla and 'Anayzah. In Central Jordan, there are Bani Sakhr and Belqawiyyahs. While Huwaytat and Bani Hamidah are present in the South (bin Muhammad, 1999) (Figure 3-4).

The main Bedouins tribes residing and settled in Azraq districts are Bani Sakhr, Al Sarhan and Rtemeh from the Abad tribe, and the Al Masa'id (North Badia). The Bedouins are pastoralists by tradition and depend on trading and animal breeding for a living. When agriculture activities boomed in Azraq, Bedouins started cultivating lands legally and illegally (Chapter 5) to gain an easy profit, also using their tribal power in order to sell lands and laborers to outsiders as brokers.

Chechens left Caucasus towards the Middle East, escaping from the war with Russia at the end of 19th century to preserve their religious freedom and culture (Nelson, 1973 and Mesnil and Habjoka, 2012). Some of the Chechens settled in Turkey and Syria whereas others settled in Jordan. The first wave of Chechens reached Jordan in 1902 and consisted of about 70 families settled firstly in Zarqa then in Sweileh, in Amman (1904) and in Sukhneh (1911). The first wave of Chechens reached Azraq in 1912 and they settled in South Azraq, near the Qaa, named also as Azraq Ash-Shishan, in reference to them (Mesnil and Habjoka, 2012). They engaged in farming and cow milk production. Nowadays the total number of people claiming Chechen origin in Jordan is around 20,000.

Druze in Azraq originally come from Jabal Al Arab (Jabal Al Druze), Al-Sweida'a governorate in Syria, located just across the border. In 1918s, after a confrontation with the French, some settled in North Azraq, also named after them as Azraq al Druze (Firro, 1992; IUCN, 2007; GIZ, 2010; Janssens and Thill, 2013). Before building houses in Azraq, they first sheltered in Azraq castle (Firro, 1992; Quntar, 2005). Generally, the Druze are citizens of Syria, Jordan and Lebanon. The main Druze tribe living in Jordan is the "Bani Ma'arouf" tribe. 


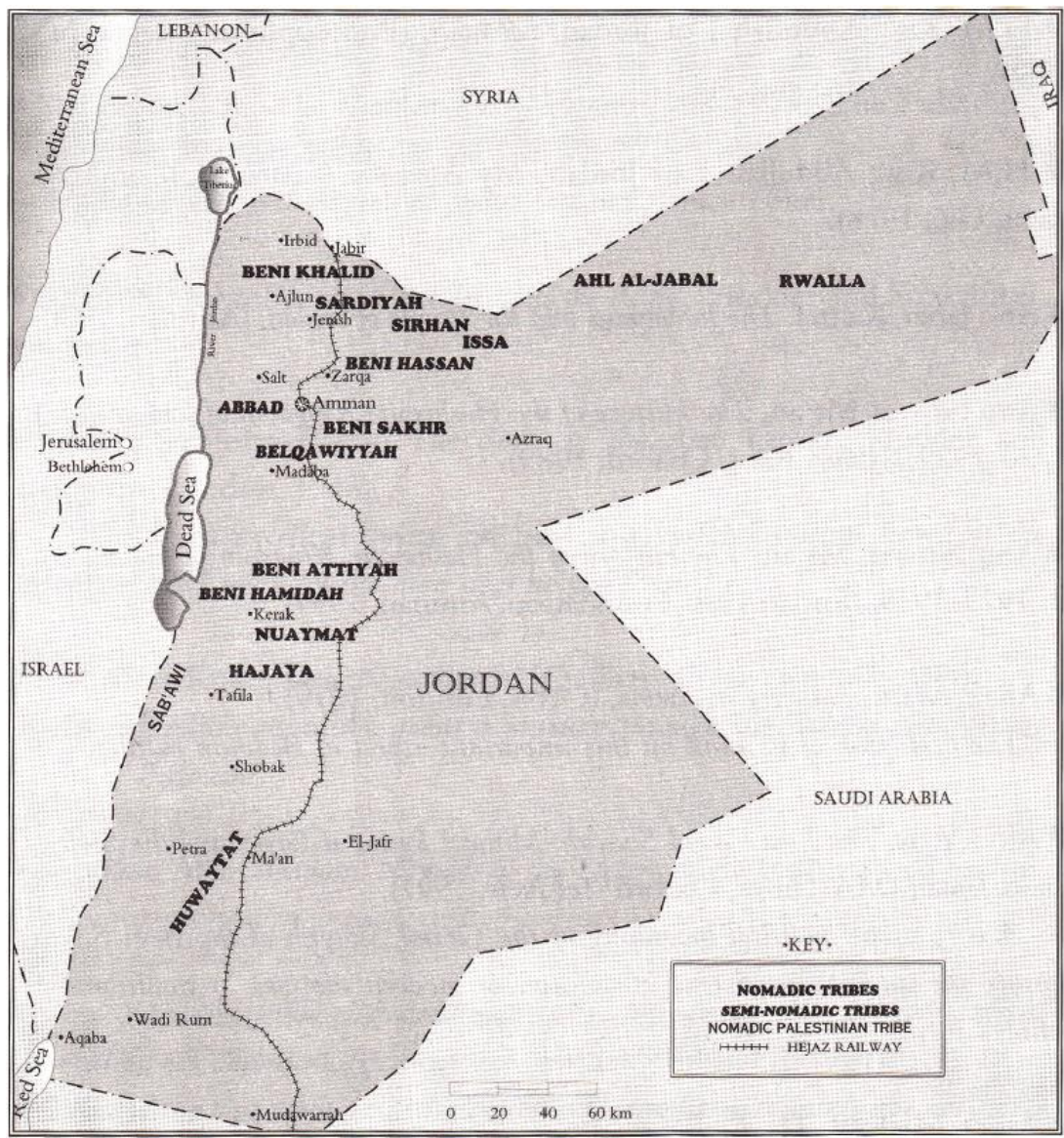

Figure 3-4. Bedouin tribes areas (bin Muhammad, 1999)

The most important source of income for the Druze people of Azraq was salt production. It started accidently in 1924 when a man dug out a hole in the ground as a lurking place for hunting purposes, and water running out of the hole evaporated, leaving the salt (Quntar, 2005). Afterwards, extracting salt in the area known as Malalhat, near Azraq Qaá, became the main source of living for the population of Azraq together with farming, until the closing of the salt industry, after which the Druze converted to agriculture.

Chechens and Druze have a Jordanian national identity number and are not treated as outsiders but as full Jordanian citizens. Relations between communities in Azraq are discussed in Chapter 5.

\subsubsection{Geology, geomorphology and hydrology}

The basin of groundwater in Azraq overlaps with the surface basin and covers $18,504 \mathrm{~km}^{2}$. It consists of three hydraulically-interconnected aquifers systems, each with its own chemical and physical properties: the upper, middle and lower aquifers systems (Dottridge, 1998). The upper aquifer (shallow aquifer complex) is the main aquifer in Azraq. It is composed of 


\section{Chapter 3}

quaternary sediments, basalts, Shallala and Rijam formation (Joudeh and Abu Taha, 1978; Dottridge, 1998; Hobbler et al., 2001). The geological formation of Azraq basin consists of two main formations: the first one is basalt and is located in the northern part of the basin, while the second formation is the limestone B4 formation (Figure 3-5). The B4 formation together with the basalt are part of the upper aquifer complex. The thickness of the basalt formation in the upper aquifer system increases toward Jabal al Arab, where it approximately reaches $1500 \mathrm{~m}$. Water table can be found within few meters near the surface in this aquifer in Azraq area district and groundwater quality is considered good (GIZ, 2010; Mesnil and Habjoka, 2012).

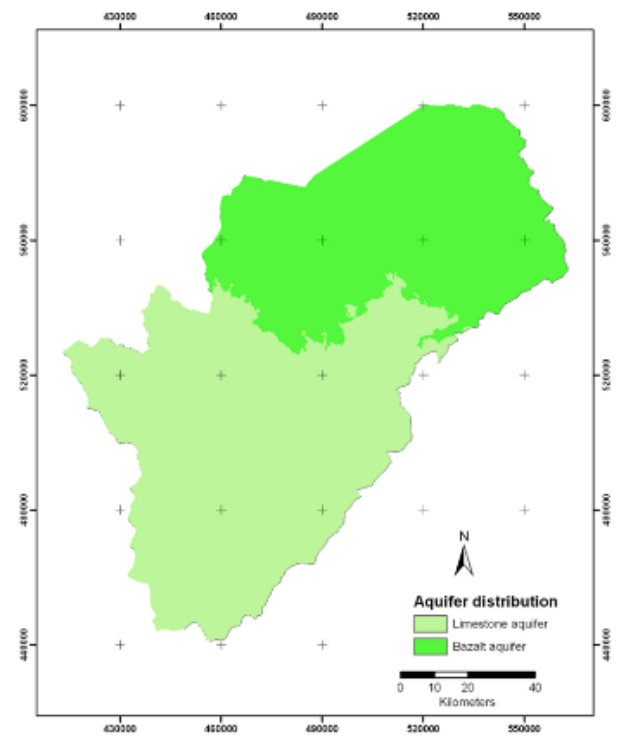

Figure 3-5. Aquifer distribution in Azraq basin (Jasem and Al Raggad, 2010)

The middle aquifer complex is a very old complex of hundred thousands of years old, which consists of Amman Wadi Sir limestone (B2/A7) (Dottrige, 1998). Water quality in this aquifer is mineralized with high Sulfurous concentration. The total dissolved solids concentrations in the aquifer ranges between 200 and 2500 (mg/L) (Hobbler et al., 2001).

The lower aquifer complex (Disi Sandstone Aquifer Complex) is also considered old since it was recharged during the last humid period, probably about 5000 years ago (Hobbler et al., 2001) (Dottrige, 1998). The depth of this aquifer reaches around $900 \mathrm{~m}$ below surface with bad water quality.

The basin is under arid to semi-arid climatic conditions characterized by hot and dry summers and fairly wet and cold winters. The mean annual precipitation into the basin ranges from 50 $\mathrm{mm} / \mathrm{yr}$ in the Azraq district area, up to $500 \mathrm{~mm} / \mathrm{yr}$ in the Syrian part. Annual rainfall patterns in the Jordanian part of the basin vary between $100-150 \mathrm{~mm}$ in the west and north of the basin, 50-100 $\mathrm{mm}$ in the center, and less than $50 \mathrm{~mm}$ in the south and east of the basin (JMD, 2011). The yearly average precipitation for the entire basin is $87 \mathrm{~mm} / \mathrm{yr}$, occurring between January and March. The mean daily temperature in winter is less than $10^{\circ} \mathrm{C}$ and the 
maximum temperature is $45^{\circ} \mathrm{C}$. The average potential evaporation rate in the area is 2,400 $\mathrm{mm} / \mathrm{yr}$ (El Naqa et al., 2007). The dominant soil type in the region is a silty clay loam soil with high soluble salt content in the subsurface horizon. Soils are primarily composed of limestone or covered with basalt boulders that resulted from volcanic out-cropping centered on Jabal Al Arab (DLU, 1994).

The topography of Azraq basin is concave and Azraq Qaá (the mudflat and its wetland) is located at the center of it (Figure 3-6, adapted from Al Raggad, 2015). Groundwater flow is radial in the upper aquifer system toward Azraq Qaá; streams are also flowing toward it from all directions, accumulating in the Qaá, discharged by the springs and recharging groundwater. Four major springs used to discharge in Azraq; two in Azraq South (Al Soda spring and Al Qaisia spring), and the other two in Azraq North (Al Aura spring and Al Mostademeh spring).

The main source of recharge in the basin comes in the form of precipitation that flows from Jabal al Arab, south of Syria and/or vertical hydrodynamic recharge through fractures and faults between the different aquifer formations systems (Mesnil and Habjoka, 2012; Al Raggad, 2007). The largest portion of groundwater recharge goes to the basalt formation (ibid.), while only a small amount of water reaches the B4 formation either through percolation from the basalt or directly during rare thunderstorm events (ibid.). MWI estimated that the northern part of the basin has an annual recharge rate of $11 \%$ against $3 \%$ for the southern part \% (MWI and WAJ, 2010). 50\% of the recharge is lost by evaporation and $50 \%$ infiltrates into the ground (Huber, 2010).

Several authors have attempted to estimate the recharge of the basin through either quantitative recharge estimates or qualitative studies (Table 3-2). From this table, it is obvious that there is uncertainty when it comes to groundwater recharge, as the numbers vary from one scholar to the other.

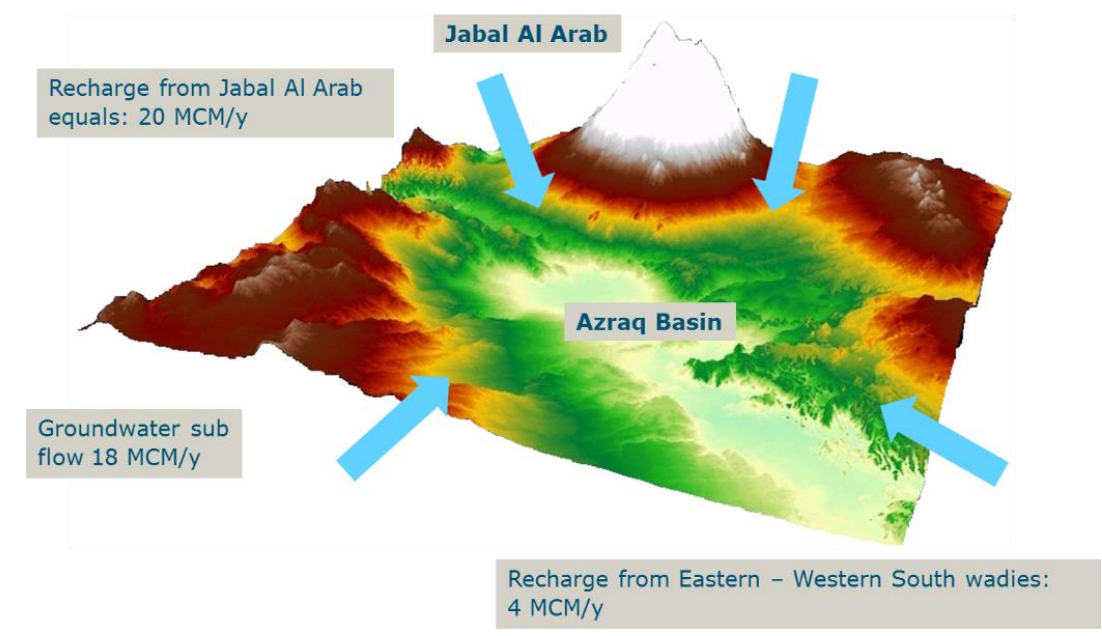

Figure 3-6. Topography of Azraq basin (MWI, 2010; Al Raggad, 2015) 


\section{Chapter 3}

Table 3-2. Estimation of Azraq basin recharge (Noble, 1998; Sharif, 2009; El-Naqa, 2010; Shawaqfeh, 2015)

\begin{tabular}{|l|l|}
\hline Study & Recharge estimate $\left(\mathrm{Mm}^{3} / \mathrm{yr}\right)$ \\
\hline Baker, 1956 & $32-240$ \\
\hline UNDP, 1966 & 20.9 \\
\hline Barber and Carr, 1973 & 35 \\
\hline Mudallal, 1968 & 30 \\
\hline Howard, 1982 & 33.1 \\
\hline Arsalan, 1976 & 35 \\
\hline Noble, 1998 & 37 \\
\hline Sharif, 2009 & 15 \\
\hline El-Naqa, 2010 & 34 (infiltrated) + 20 (natural) \\
\hline MWI, 2010 & 34 \\
\hline Shawaqfah, 2015 & 34 \\
\hline
\end{tabular}

Michael Baker, through the "Alia Project", was the first scientist who worked on estimating the basin recharge based on the estimate of Azraq's four main springs discharge. The results showed an annual recharge of $32-240 \mathrm{Mm}^{3}$. Based on this result, Baker gave a positive recommendation to use groundwater for extensive agriculture development in the area (Baker, 1956; UNDP, 1966). The results of Baker were not satisfactory to the government authorities and UNDP was asked to estimate the recharge again. They used Penman ET approach and found a recharge of only $20.9 \mathrm{Mm}^{3} / \mathrm{yr}$, recommending that only $10.3 \mathrm{Mm}^{3} / \mathrm{yr}$ should be used in order to sustain the basin and springs for the near future (UNDP, 1966). The situation did not last long as the government decided in 1963 to divert and transfer spring water from Azraq to Irbid for urban purposes (UNDP, 1966; Nelson, 1973). A system of pumping stations and a pipeline was built in order to convey water over more than $125 \mathrm{~km}$ from the northwest of Azraq. Later, in 1980, the government also began to convey water through direct spring intake to Amman at an average rate of $900 \mathrm{~m}^{3} / \mathrm{hr}$, which corresponds to around $75 \%$ of total spring discharge. In 1981, the Water Authority of Jordan replaced the spring flow diversion by fifteen artesian wells northwest of the Northern Azraq springs, which directly and dramatically affected spring discharge (IUCN, 2007). Urban abstraction in parallel with agriculture expansion affected groundwater quantity and quality in the basin negativity and in 1987 the north Azraq spring dried out, with only the springs of South Azraq still flowing, until they stopped in 1992. Table 3-3 shows springs discharge throughout the years in parallel with governmental abstraction for urban use (RSCN, 1990). Figure 3-7 estimates withdrawals from groundwater wells with springs discharge (RSCN, 1990).

The Qaa area is the lowest part of the basin; it is located above the saline aquifer where water is characterized by high salt concentration. Precipitation events in Azraq occur with high intensity in a short period, causing floods from wadis and streams to accumulate in the Qaá. There are nine main wadies flowing to the Qaa from the north east and southwest of the basin (Figure 3-8). 
Table 3-3. Estimated withdrawals from groundwater wells with spring discharge (RSCN, 1990)

\begin{tabular}{|l|l|l|l|}
\hline Year & $\begin{array}{l}\text { Withdrawal from government } \\
\text { wells }\left(\mathrm{Mm}^{3}\right)\end{array}$ & $\begin{array}{l}\text { Estimated withdrawal from } \\
\text { private wells }(\mathrm{Mm} 3)\end{array}$ & Spring discharge (Mm3) \\
\hline 1981 & - & 1.50 & 10.49 \\
\hline 1982 & 9.50 & 1.50 & 8.35 \\
\hline 1983 & 12.31 & 1.50 & 6.60 \\
\hline 1984 & 14.36 & 2.00 & 6.04 \\
\hline 1985 & 15.64 & 3.50 & 5.27 \\
\hline 1986 & 13.72 & 4.50 & 3.57 \\
\hline 1987 & 14.00 & 8.00 & 4.11 \\
\hline 1988 & 19.64 & 12.00 & $2.15^{3}$ \\
\hline 1989 & 16.92 & 12.00 & $1.96^{4}$ \\
\hline
\end{tabular}

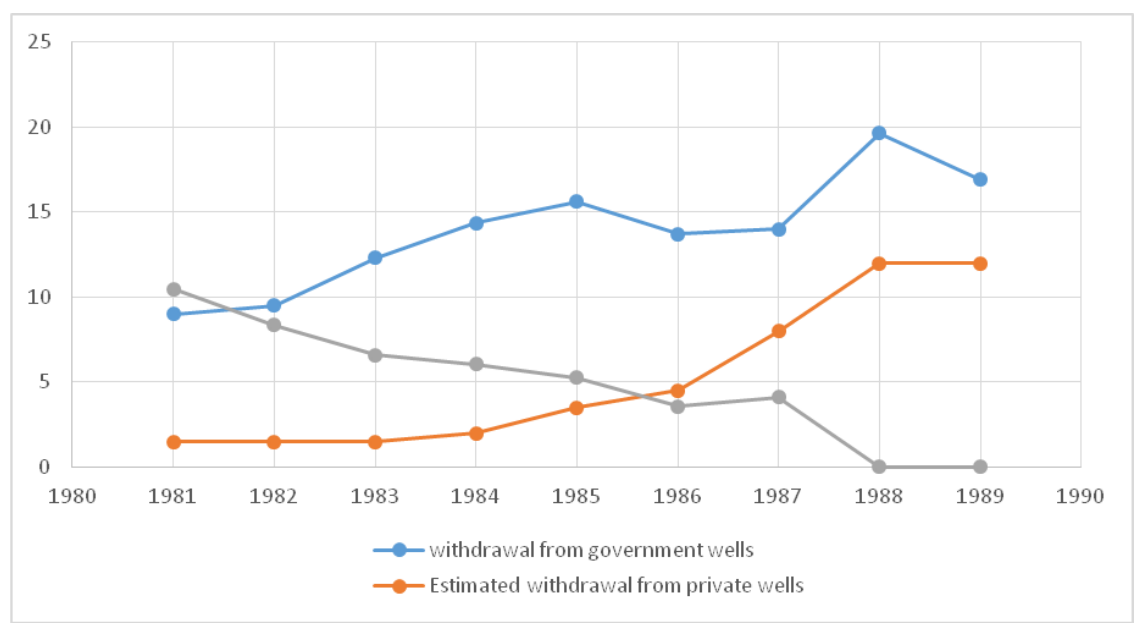

Figure 3-7. Estimated withdrawal from groundwater wells and spring discharge $\left(\mathrm{Mm}^{3} / \mathrm{yr}\right)$ (RSCN, 1990)

Accumulation of wadi and stream water has a minor contribution to groundwater recharge, as a major portion of it evaporates, causing an increase in salinity in the area. The Ministry of agriculture in cooperation with Jordan Water Authority has built three dams and several infiltration systems for harvesting the flood water in areas with higher permeability. Accordingly, the flooded water in the Qaá has decreased, which also affect the Azraq wetland system located at the heart of the Qaá (Al Naber, 2016).

The official recharge of the basin estimated lately by WAJ and MWI equals $42 \mathrm{Mm}^{3}: 20 \mathrm{Mm}^{3}$ and $4 \mathrm{Mm}^{3}$ are recharged by precipitation in the northern and southern part of the basin respectively, and $18 \mathrm{Mm}^{3}$ is considered as groundwater subsuperficial-flow. Surface runoff contribution to the recharge is minor as water accumulates in Azraq's Qaá and largely evaporates (MWI and WAJ, 2010). The estimated sub-superficial flow is questioned as overestimated by different researchers, pointing to the situation of overexploitation in both

\footnotetext{
${ }^{3}$ Only Azraq South springs were flowing.

${ }^{4}$ Only Azraq South springs were flowing.
} 


\section{Chapter 3}

region Syria and Jordan, especially with the springs drying out (Mesnil and Habjoka, 2012; Al Raggad, 2007; Al Raggad, 2010; Jasem, 2015). The safe yield of Azraq basin is taken as 24 $\mathrm{Mm}^{3}$, while the official current abstraction reaches $215 \%$ of the safe yield.

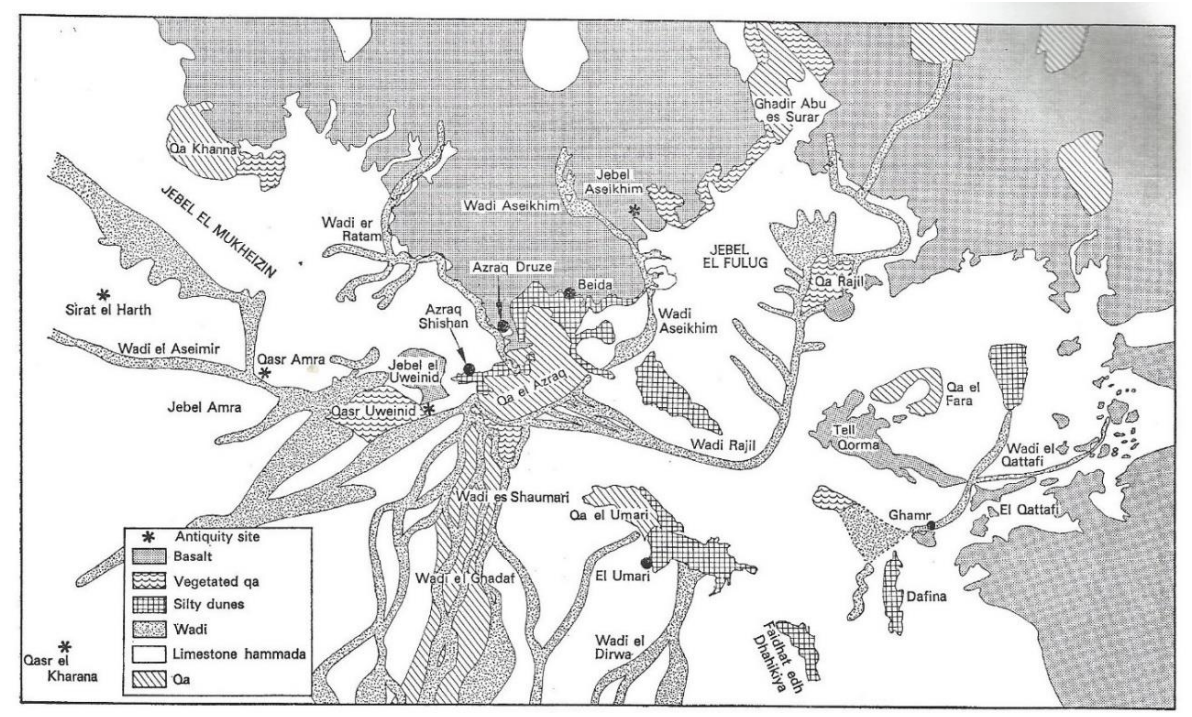

Figure 3-8. Wadis and streams in Azraq basin (Nelson, 1973)

Al Raggad (2015) studied the effect of climate change on the basin recharge. He indicated that if the average long term of rainfall increased by $20 \%$ then the recharge of the basin would increase by $60 \%$, while if it decreased by $20 \%$ then the recharge would be affected negatively and decrease by as much as $52 \%$. He also indicated that if the average long-term temperatures increased by $1^{\circ} \mathrm{C}$ then the recharge would decrease by $11 \%$, and if it increases by $2^{\circ} \mathrm{C}$ then the recharge would decrease by $23 \%$ (Al Raggad, 2015). Al Zubi (2009) confirmed that annual recharge in Azraq basin would decrease under scenarios of increase in temperature and fluctuation in precipitation.

\subsubsection{The Azraq wetland reserve and oasis}

Azraq wetland reserve (previously Azraq oasis) is located at the lowest point of Azraq basin with a total area of $12 \mathrm{~km}^{2}$ (Figure 3-9). Azraq wetland is the only significant wetland located in Jordan and is managed by the RSCN (Royal Society for the Conservation of Nature). The oasis was formed from the accumulated natural discharges from streams, four springs and wadi floods from all direction toward Azraq (UNDP, 1966; Nelson, 1973; Daoud et al., 2006; Haleh, 2007; IUCN, 2007). In 1977, Azraq wetland was declared by UNESCO as an international Ramsar site under the part of Ramsar convention of 1971 . The wetland is considered as an important reserve and a major station for migratory birds in the AfricanEurasian flyway (RSCN, 2017). Yearly, up to one million birds of different varieties stop in the reserve along their migration routes to rest and breed in the wetland (RSCN, 2017). In addition to birds, the wetland hosts a variety of flora, fauna, aquatic and terrestrial species including the Killifish Aphanius Sirhani fish, which can only be found in Azraq wetland reserve (Halah, 2007; IUCN, 2007). The favorable climatic condition and the wetland diversity 
attracted a multiplicity of organisms, forming one of the most unusual ecosystems in the world (Scates, 1966; Jones, 2012).

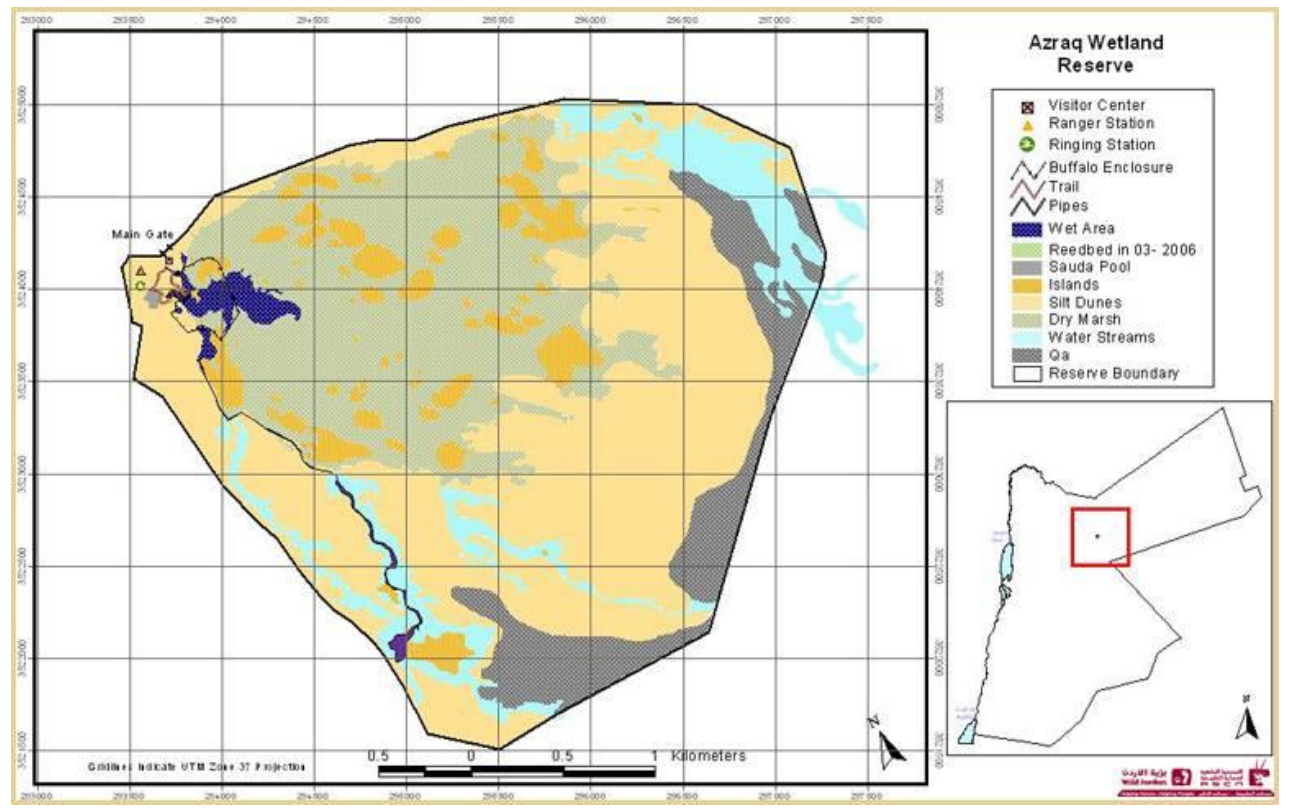

Figure 3-9. Azraq wetland reserve (RSCN, 2017)

As the wetland reserve largely depended on the four Azraq springs flow, it lasted as an outstanding example of a wetland until the beginning of 1990s due to extensive use from government for urban use and from farmers for agricultural purposes (Al-Eisawi, 2012). In 1980 , the spring water flowing into the wetland was estimated at $10.49 \mathrm{Mm}^{3}$. After ten years the discharge had decreased to $300-400,000 \mathrm{~m}^{3}$ until it reached zero in 1992. As the natural flow to the wetland stopped the area of the water catchment decreased down to $90 \%$ of its former size. In 1994, the RSCN in collaboration with the United Nations Development Programme (UNDP) started a project aiming to rehabilitate the wetland by pumping artificially from groundwater wells owned by WAJ. RSCN and UNDP on one side, and WAJ on the other, agreed on an annual volume of about $1.5-2.5 \mathrm{Mm}^{3} / \mathrm{yr}$ for the wetland. The first amount of water pumped for the wetland was about $1.38 \mathrm{Mm}^{3}$ in 1996 , but this annual artificial recharge was never constant, as it depended on the basin groundwater situation and urban demands. The maximum annual recharge was recorded in $1999\left(1.53 \mathrm{Mm}^{3}\right)$. After that year the pumped recharge decreased to reach only $406,000 \mathrm{~m}^{3}$ in 2012 . The wetland only succeeded in recovering $10 \%$ of its earlier water catchment area. This action, however, sustained the biodiversity of the wetland, and Al Sirhani fish species still exist in the reserve. Birds continue to migrate. Figure 3-10 shows the fluctuation in pumped water to the wetland through years. 


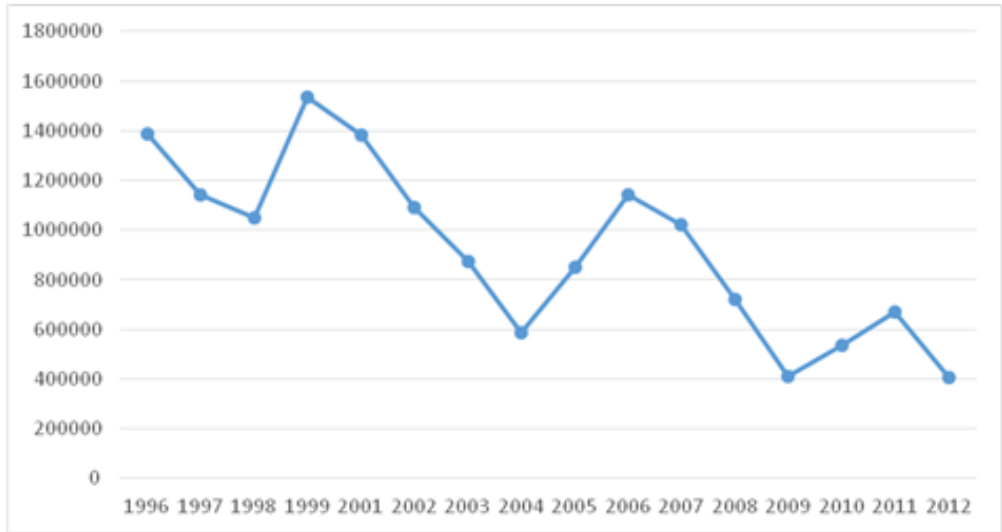

Figure 3-10. Artificial recharge into Azraq Wetland Reserve ( $\left.\mathrm{m}^{3} / \mathrm{yr}\right)$ (RSCN, 2013)

\subsubsection{The Azraq salt Industry}

Salt production started with the Druze in 1924, but it was only in 1986 that a salt industry was established in Azraq, named 'Azraq salt industry', through the Azraq cooperative society (KREBS SWISS, 1996). The cooperative was managed mainly by Druze, with $3 \%$ only of the members being Chechen (Ramsar, 1990; Ronay, 1993; KREBS SWISS, 1996). The main function of the cooperative was to control the production and distribution of salt inside and outside the country (Ronay, 1993). The industry was considered at that time as the most lucrative economic activity in the basin, as it provided job opportunities for Azraq locals (Al Naber, 2016). Groundwater was pumped to the surface in a place known as "Al Malalhat" (Figure 3-11), characterized by a groundwater with a high level of salinity. As locals indicate, pumping the saline water out of the aquifer contributed to decrease the salinity of the aquifer by $20 \%$ (Al Naber, 2016).

Saline water was extracted between June and August through small electric pumps and accumulated in a pond for 24 hours for the sediments to settle (Al Naber, 2016). The extracted water was then conveyed through pipe to large shallow basins $(8 \times 50 \times 1 \mathrm{~m})$ directly exposed to the sunlight (Ramsar, 1990; Ronay, 1993). The sun made the water evaporate, leaving a dry crystallized salt which was trucked to the salt factory for processing and packaging and distribution throughout Jordan and beyond under the brand name of 'Azraq Salt' (Ramsar, 1990; Ronay, 1993). 


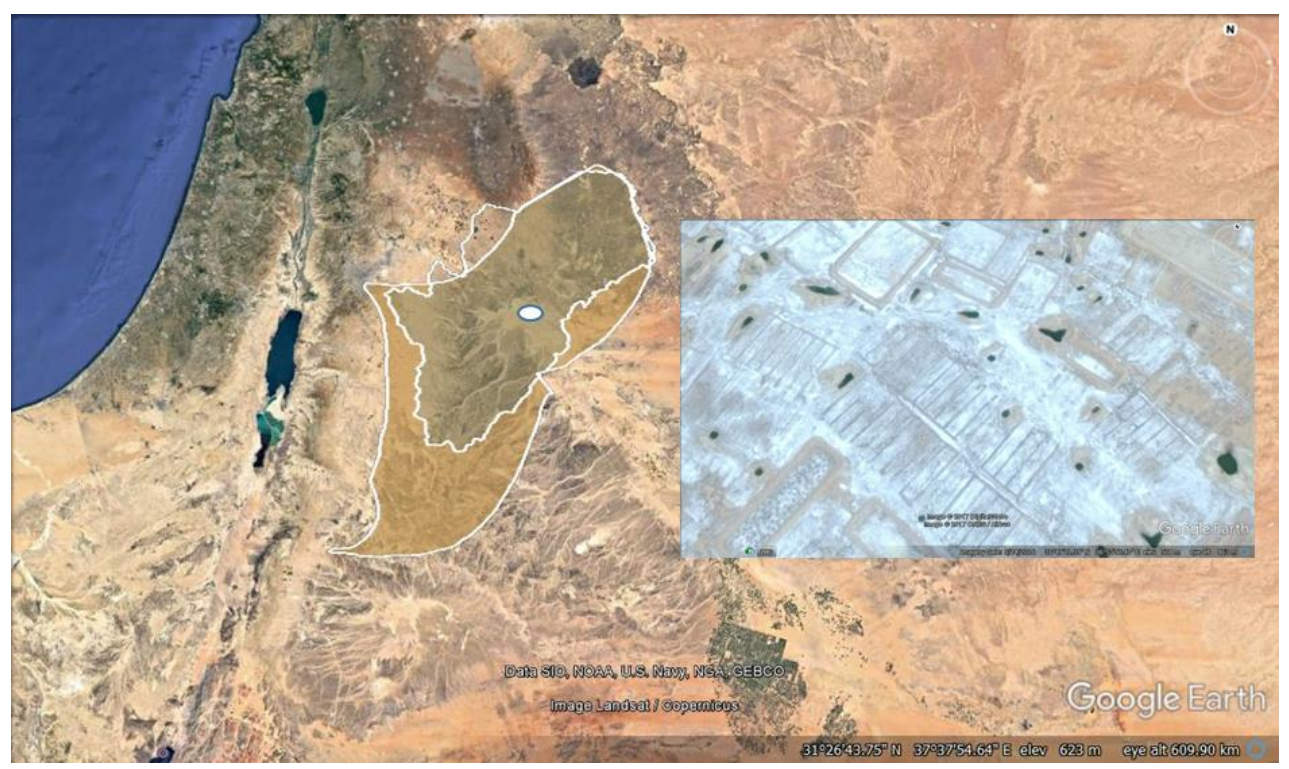

Figure 3-11. Azraq surface and groundwater basin and Malahat area (Google Earth)

The industry contributed to achieving Jordan's self-sufficiency in salt and to a small export market to Iraq with an average total annual production of 40,000 ton (Ramsar, 1990). The success of Azraq Salt Industry lasted only ten years, as in 1996 a new salt industry was established in Jordan with a budget of $€ 17$ million under the name of "Safi Salt Company", producing salt from the Dead Sea (Al Naber, 2016). The presence of a new competitor in the salt production business affected Azraq's salt industry negatively for several purposes: Safi Salt Company produced 1.2 million tons of industrial salt per year compared with only 40,000 ton in Azraq; the production cost of Safi Salt was lower than Azraq Salt since pumping water in Azraq needs energy while it is available on the surface in the Dead Sea; and the quality of Safi salt is better than Azraq salt due to the high sulphate concentration in Azraq salt. Consequently, the market for Azraq salt decreased and the factory closed up in 2006 (Ramsar, 1990; Ronay, 1993; KREBS SWISS, 1996). Figure 3-12 shows people working in salt production in Azraq. 


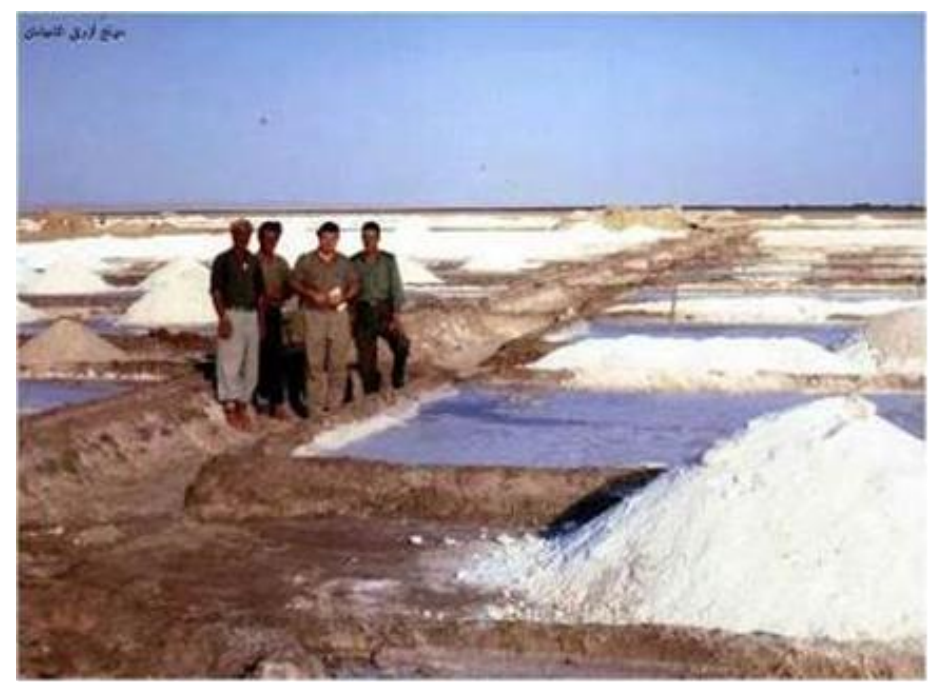

Figure 3-12. Salt production in Azraq (Azraq wetland Facebook page)

\subsubsection{Agriculture development and the use of groundwater}

\subsubsection{Agriculture and groundwater use in Azraq}

Groundwater use in Azraq basin started in the 1960 when the government decided to use the spring water and conveyed it to Amman, first, and then to Irbid and Zarqa for urban use. This was quickly followed by wells drilled by the governmental and abstraction for different purposes: domestic, industrial, agriculture and environmental use. As it appears from official data shown in Table 3-4, the total abstracted water from the basin is $51.6 \mathrm{Mm}^{3}$, which is around $215 \%$ of the basin safe yield. The major consumer of groundwater is agriculture (28 $\mathrm{Mm}^{3}$ ) followed by domestic use $\left(23 \mathrm{Mm}^{3}\right)$ (MWI, 2009).

Table 3-4. Groundwater abstraction in Azraq basin

\begin{tabular}{|c|c|c|c|}
\hline & $\begin{array}{l}\text { Abstraction rate } \mathrm{Mm}^{3} \\
\text { (2009) }\end{array}$ & Safe yield $\mathrm{Mm}^{3}$ & $\begin{array}{l}\text { Abstraction } \\
\text { rate } \%\end{array}$ \\
\hline Private drinking wells & 0.32 & & \\
\hline Governmental drinking wells & 22.9 & & \\
\hline Industrial purpose & 0.35 & & \\
\hline Agricultural purpose & 28 & & \\
\hline Rural area & 0.09 & & \\
\hline Total & 51.66 & 24 & $215 \%$ \\
\hline
\end{tabular}

Desert agriculture has been developed in Azraq basin since the 1960 s driven by the improvement in well-drilling techniques, the decrease in energy costs, land affordability and accessibility, and good water quality and quantity (Molle et al., 2017a). Farming in Azraq was considered as a prime investment option, and investors and local farmers enjoyed a good economic return from these activities. The expansion in cultivated area was encouraged by the government who freely awarded licenses for wells in the 1980s and early 1990s. Sensing the increase in groundwater use in the area in the late 1980s, the government tried to control abstraction by introducing special laws for groundwater use, with measures and tools 
to control abstraction, including banning new wells, introducing metering, water tariff, restriction areas and control of drillers, etc (Chapter 6). However, abstraction continued to increase, and so did the number of illegal wells; the agricultural area expanded and groundwater became over-abstracted. Several recent studies conducted in the Azraq basin have found that actual groundwater use for agriculture in the basin might exceed three times the official recorded data (Al Bakri, 2015; USAID, 2014). According to the Ministry of Agriculture, cultivated land surface increased between 2005 and 2011 from 61,200 du to 114,320 du (MoA, 2012) (Figure 3-13).

The development of agricultural has continued with the introduction of new crops such as grapes and pomegranates, diversifying away from traditional olive trees. More recently, farmers have attempted to cultivate alfalfa due to its high yield and high revenue, despite its high-water consumption. Alfalfa cultivation is mainly grown based on illegal wells, or on wells without meter, so that farmers can avoid paying for their high-water consumption. The increasing trend in groundwater abstraction slightly subsided during the mid-2000s due to the decline in water table levels, the decrease in well productivity, and an increase in water salinity.

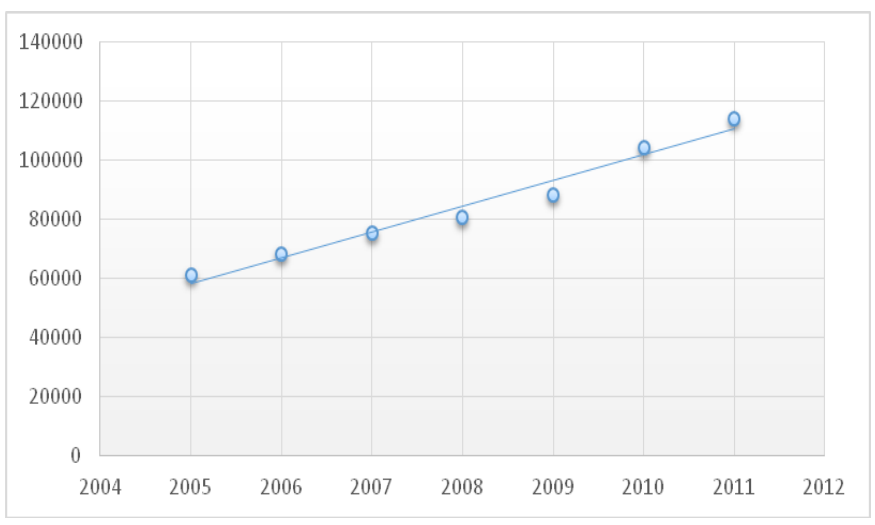

Figure 3-13. Evolution of the cultivated area in Azraq (in dunum) (MoA, 2012)

Agriculture first concentrated around Azraq city (Azraq north and south). In the beginning of 1990s it expanded to eastern Azraq (farm area) and Mafraq. The characteristics of agriculture activities vary from Azraq to Mafraq. Water table in Azraq is near the surface, down to a maximum of $50 \mathrm{~m}$, and extraction costs are low; in Mafraq in contrast water table can be found at a maximum depth of $550 \mathrm{~m}$, which means very high well drilling and extraction costs compared with Azraq. Land in Azraq was cheaper, with an opportunity to speculate, while in Mafraq it was much costly since it is sold with an official land deed. All these factors are presented and further studied in chapter (7).

\subsubsection{Water level}

The Water Authority of Jordan has dug sixteen wells for monitoring purposes in Azraq (AWSA field). The monitoring results showed an increase in abstraction in parallel with the increasing number of wells and agriculture expansion, causing a decrease in water table levels by about 25 meters during the last 28 years (Figure 3-14). The fluctuation that appears in the figure is 


\section{Chapter 3}

caused by the yearly recharge events but unfortunately these are not enough to offset the negative water balance between discharge and recharge.

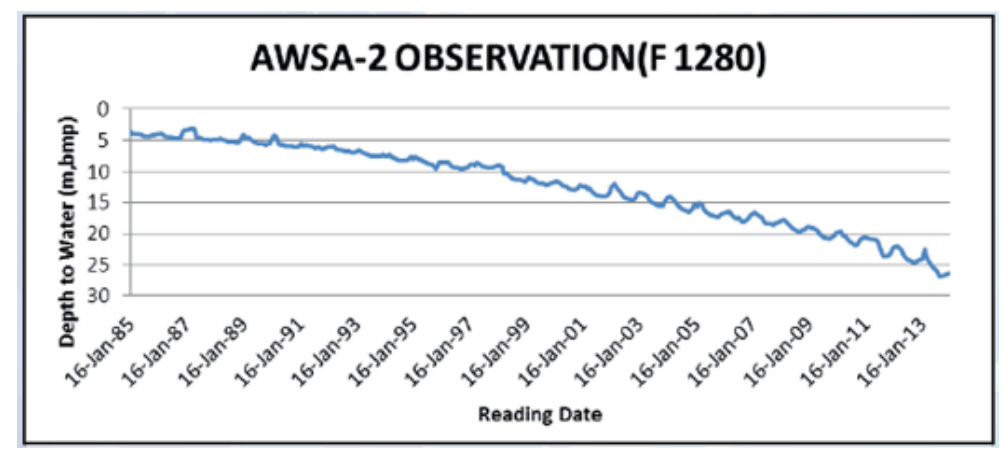

Figure 3-14. Decrease in water table data in monitoring AWSA well (MWI, 2013)

Abdulla et al. (1999) studied the decline in groundwater level in Azraq basin using threedimensional groundwater flow model. They predicted the decline in groundwater level for four different scenarios for the years 2005, 2015 and 2025. The first scenario where the pumping rate is $45.5 \mathrm{Mm}^{3}$; the second scenario where the pumping rate is $22.7 \mathrm{Mm}^{3}$; the third scenario where pumping rate is $68.1 \mathrm{Mm}^{3}$ and the last scenario equals to the basin safe yield. Results showed that water table will dropped 25 m in 2025 under the first scenario, while a pumping of $68.1 \mathrm{Mm}^{3}$ would generate a drop of the water table of $39 \mathrm{~m}$ (Table 3-5).

Table 3-5. Prediction of groundwater table decline (Abdulla et al., 1999)

\begin{tabular}{|l|l|l|l|}
\hline Scenarios & Maximum drawdown $(\mathrm{m})$ & \multicolumn{2}{l|}{} \\
\hline & 2005 & 2015 & 2025 \\
\hline SC 1 & 20.01 & 22.85 & 25.32 \\
\hline SC2 & 12.9 & 12.53 & 12.46 \\
\hline SC3 & 27.74 & 33.82 & 39.2 \\
\hline SC4 & 13.6 & 13.53 & 13.68 \\
\hline
\end{tabular}

\subsubsection{Groundwater wells}

Wells in Azraq can be divided into four categories according to their legal status:

- Legal wells with a license (rukhsa) from WAJ;

- $\quad$ Illegal wells registered in the WAJ database but which got a temporary permit (ijaza)

- $\quad$ Illegal registered wells which have no permit;

- Illegal wells unknown to WAJ

Official abstraction rates are calculated based on meter readings of legal and illegal registered wells, or estimated based on the cultivated area and cropping patterns with help of satellite images for the un-metered wells. In 1984 the number of wells in Azraq were recorded at 254 dug (shallow) wells and 73 boreholes wells, abstracting in total around 8 $\mathrm{Mm}^{3} / \mathrm{yr}$ (GIZ, 2010). Nowadays, all shallow wells have been closed or turned into boreholes wells. According to official statistics, the number of wells reached 1,316 in 2009 and the total 
abstraction volumes reached around $51 \mathrm{Mm}^{3}$, of which $28 \mathrm{Mm}^{3}$ for agriculture. Molle et al. (2017a) indicated a decrease in number of well in the basin in 2017, as the official number of function wells were cited as 580 wells abstracting $52.54 \mathrm{Mm}^{3}$ annually (Molle et al., 2017a)

Figure 3-15 and Figure 3-16 shows the location of (most) active registered legal and illegal wells. Groundwater salinity in the basin based on WAJ database ranges between 100 and 7,000 ppm. However, 206 wells out of a sample of 225 wells have a range of salinity of 5002500 ppm, with a few cases where salinity concentrations are above 4,000 ppm (found in Azraq south area due to high water salinity in the aquifer and the Qa'a) (Figure 3-18)

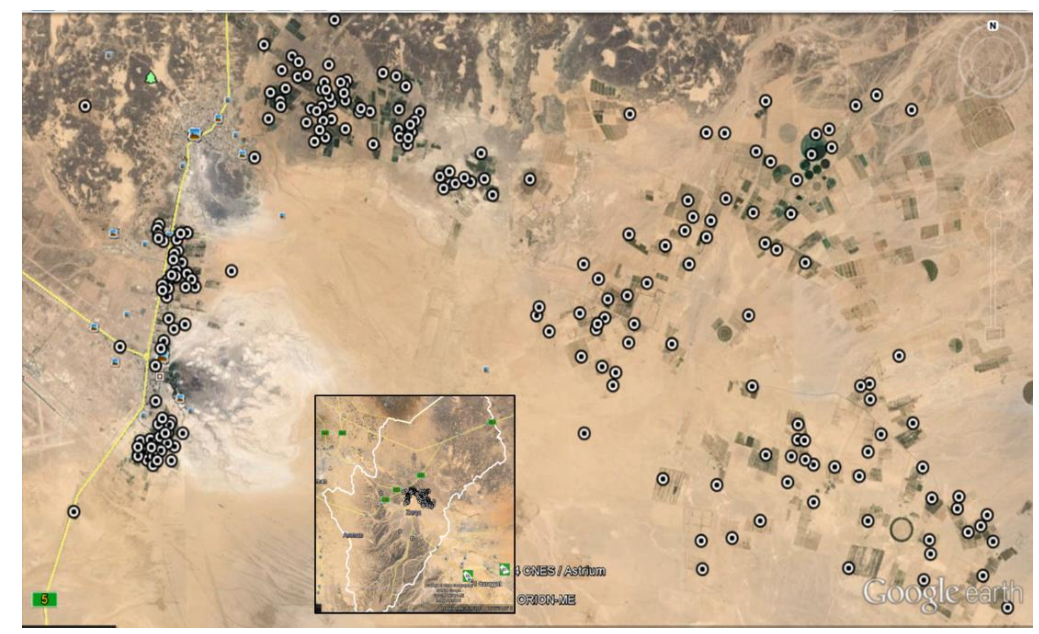

Figure 3-15. Legal wells in Azraq (Google Earth and raw data from MWI, 2010)

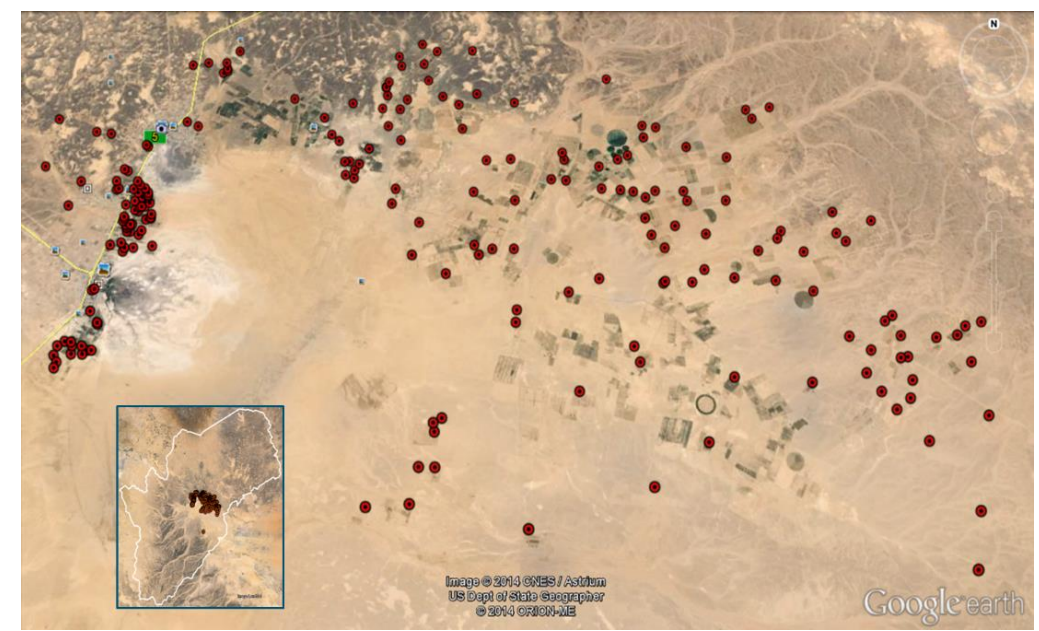

Figure 3-16. Illegal wells in Azraq (Google Earth and raw data from MWI, 2010) 


\section{Chapter 3}

According to WAJ, farmers using illegal wells abstract on average $50 \%$ more water than legal wells (WAJ, 2010) (Figure 3-17).

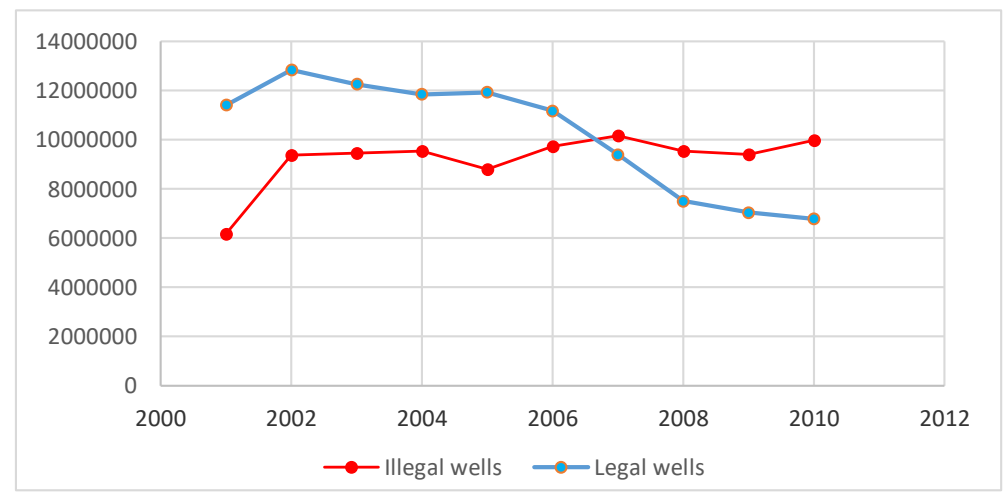

Figure 3-17. Abstraction from legal and illegal wells in Azraq ( $\left.\mathrm{m}^{3} / \mathrm{yr}\right)(\mathrm{MWI}, 2010)$

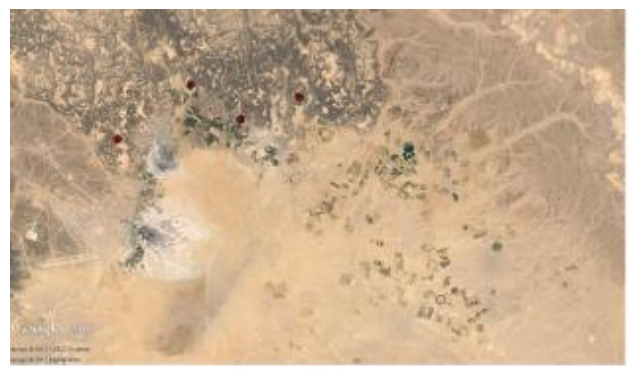

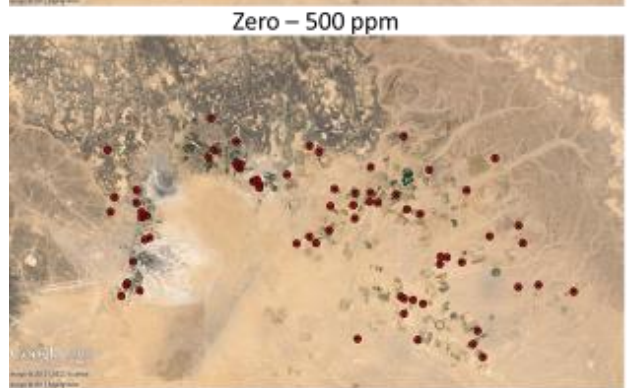

$1001-1500 \mathrm{ppm}$

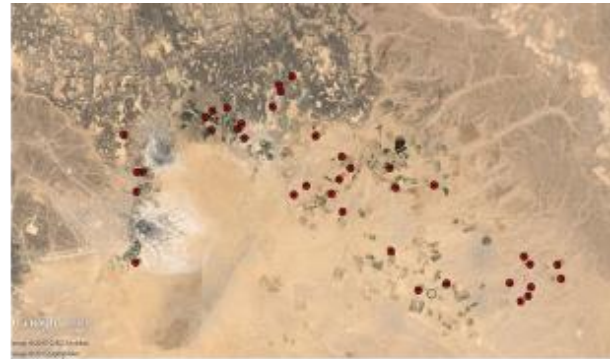

$501-1000$ ppm

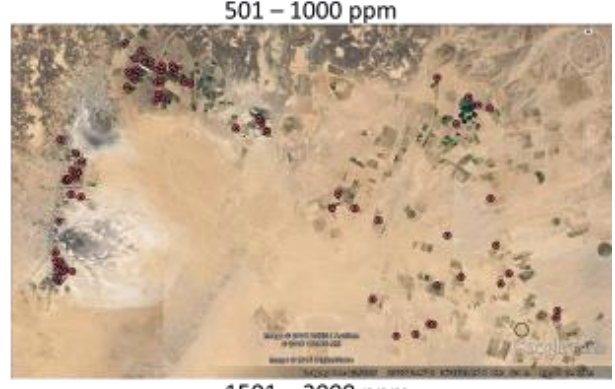

$1501-2000$ ppm 

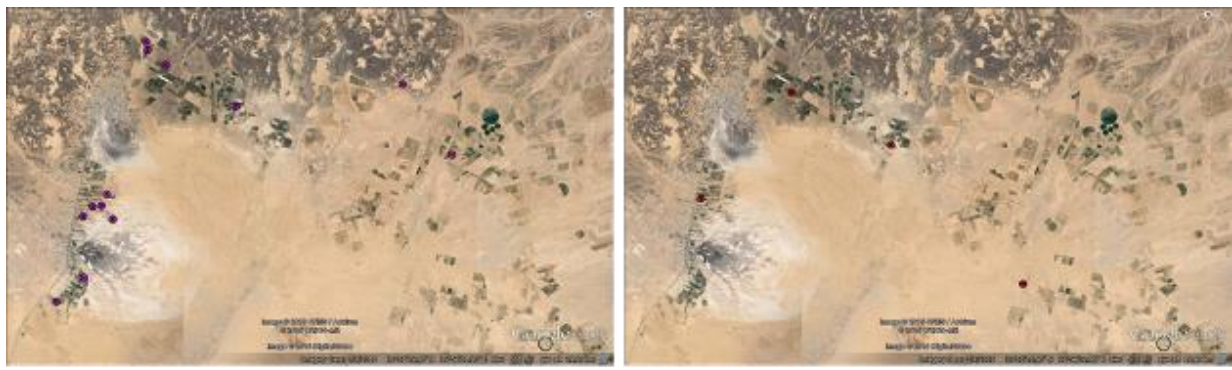

$2001-2500 \mathrm{ppm}$

$2501-3000 \mathrm{ppm}$

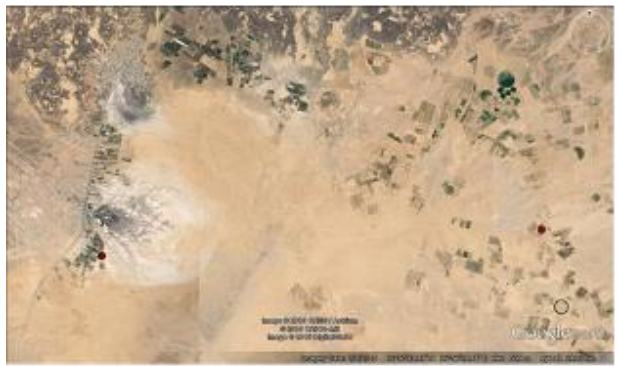

$3500-4000 \mathrm{ppm}$

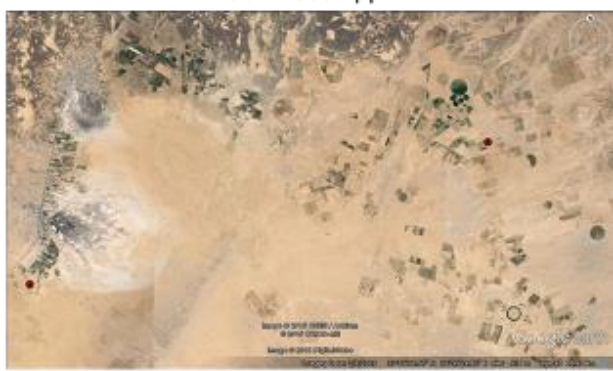

$4001-4500 \mathrm{ppm}$

Figure 3-18. Distributions of salinity in Azraq (Google Earth and raw data MWI, 2010)

In the following chapters of this study, I will define and explain the agriculture driving forces and availability of production factors in Azraq basin and studying the sustainability of agriculture activity with the elasticity of water and land policies. 



\section{CHAPTER FOUR}

\section{Explorative Spatial Analyses to Support Stakeholder Deliberation on Groundwater Management}

Al Naber, M., Stoorvogel, J. 2017. Explorative Spatial Analyses to Support Stakeholder Deliberation on Groundwater Management. To be submitted to Environmental Management Journal. 



\title{
4 Chapter Four: Explorative Spatial Analyses to Support Stakeholder Deliberation on Groundwater Management
}

\begin{abstract}
Society has to deal with an increasing pressure on the environment. It is essential to find feasible and socially acceptable solutions to manage these problems. Stakeholder involvement and participatory approaches are found to be a possible solution for natural resource management. However, during stakeholder meetings often a plethora of potential interventions is suggested. Increased data availability opens new avenues to carry out ex ante analysis to screen potential solution pathways and to focus the discussions. Explorative spatial analyses can be used to define the window of possible interventions and opportunities. The window of opportunity reflects the overlap between the feasible solutions and the options stakeholders consider being relevant and potentially achievable. A good example is groundwater management. With the increase in water demand, proper management becomes essential to safeguard limited groundwater resources for future generations. However, the overexploitation of groundwater aquifers for domestic, urban use and irrigation frequently results in a reduction of groundwater availability and quality. Groundwater policies have proven to be difficult to implement. The Azraq basin in Jordan suffers from overexploitation. The aquifer has been mined through intensive pumping during the last 20 years which caused degradation in water quality and quantity. This paper presents an explorative spatial analysis to visualize the window of opportunity in the catchment to get closure on the options for natural resource management.
\end{abstract}

Keywords: Azraq basin, Jordan, Window of opportunity, Natural resource management

\subsection{Introduction}

Society is gradually facing more environmental problems related to the increased pressure on natural resources. The global community calls for intervention through a range of initiatives like the Sustainable Development Goals. These global goals have to be implemented at local or regional scales. They require a thorough investigation of the various dimensions of the problems and of associated biophysical and socio-environmental constraints to identify the solution pathways. However, in many cases there is a lack of consensus amongst stakeholders. Natural resource management involves a wide array of stakeholders who differ in their personal backgrounds, knowledge or experiences and priorities. Stakeholders attempt to make sense of a common challenge and contextualize it within a particular set of values, ideas or political agendas (McEvoy et al., 2013). Current bio physical and social conditions vary for each situation. The variation in stakeholders and conditions leads to a dispersion of solution pathways that are proposed. In addition, typically, the suggested pathways include both feasible and infeasible options. The multitude of solution pathways and the infeasible options hampers the debate around natural resource management. In the past decades, there has been a rapid advance in data availability thanks to new techniques of data collection like remote sensing and crowd sourcing, but also of data sharing through the internet and data warehouses. As a result, it has become easier to identify potential solution pathways and to support the decision-making process by aligning stakeholders along the biophysical available options given the social constraints (Ashford et al., 2006). 


\section{Chapter 4}

Accessible data can help in defining and opening windows of opportunity that overlap with various dimensions in natural resource management. This article aims at developing a systematic framework to analyse and capture interventions in natural resources management. We will focus on groundwater-based agriculture that often suffers from groundwater over abstraction, a very common problem in a number of countries with limited water resource.

Typically, agricultural systems in arid and semi-arid regions face problems related to water stress. With most available surface water being used, the attention increasingly goes to groundwater resources. Consequently, groundwater usage has grown rapidly during the last decades. A continuous decline of groundwater levels has been observed in many countries in the past half century (Bajjali and Al-Hadidi, 2005; Gaur et al., 2001; Zhou et al., 2012). Groundwater depletion has been caused either by overexploitation for both urban and irrigation uses and/or reduction of groundwater recharge aquifers, which frequently result in a reduction in groundwater availability and quality (Konikow and Kendy, 2005). Over abstraction of groundwater aquifers exceed $100 \%$ of recharge in Saudi Arabia, Yemen, Egypt, Tunis and Morocco, 95\% in Jordan and 50\% in Iraq. Figure 4-1 shows the total renewable groundwater resources withdrawn in the world by region (Vrba and van der Gun, 2004). About $60 \%$ of groundwater withdrawn is used by agriculture while the rest is almost equally divided between the domestic and industrial sectors.

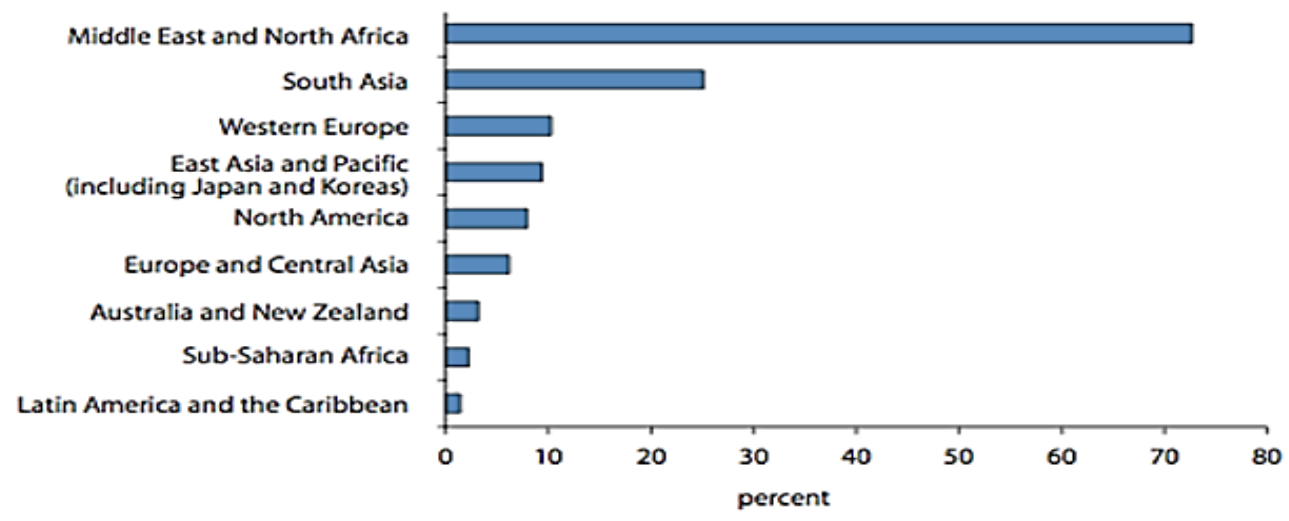

Figure 4-1. Percentage of total renewable groundwater resources withdrawn by region (FAO AQUASTAT, 1998-2002)

The explosive increase in groundwater use has been driven by different factors. Supplydriven factors, such as government subsidies, easy availability of inexpensive pumps, and drilling technologies have facilitated the accessibility of groundwater. Demand-driven factors have also resulted from groundwater's capacity to provide flexible, on-demand irrigation to support vibrant, wealth creating agriculture in all climate zones, and from the growing need to provide food for urban populations (Shah, 2007). The Food and Agriculture Organization (FAO, 2003) identified a range of social, economic and environmental consequences related to the increased use of groundwater resources: i) an increase in the vulnerability of agriculture mainly for small farms, ii) increased pumping costs and energy usage, iii) a reduction in the access to water for drinking, irrigation and other uses, particularly for the 
poor, iv) critical changes in patterns of groundwater flow to and from adjacent aquifer systems, v) a decline in stream base flow, and vi) damage to wetlands and surface infrastructure.

Sustainable strategies to manage groundwater resources are essential especially in (semilarid countries. Ostrom (1992) demonstrated the capacity of communities to manage common resources. However, in the case of groundwater, the conditions for crafting rules for sustainable management are generally not met (Schlager, 2007). Decision makers follow different approaches to conserve groundwater, either through the implementation of regulations or through a joint dialogue with groundwater users. Since groundwater policies have proven to be difficult to implement (Hammani et al., 2009; Bekkar et al., 2009; Macoun and El Nasser., 2000), stakeholder involvement and participatory approaches are found to be an alternative solution to natural resource management. Petit (2004) explains that it is often in a situation of water stress that local stakeholders recognize the common character of groundwater resources and try to find adapted solutions to over exploitation. Therefore, simple messages about over abstraction or pollution could be sufficient to prompt collective responses by the community of groundwater users. However, the perception and understanding of problems related to groundwater over abstraction are key but appear to vary considerably between stakeholders (White and Kromm, 1995; Shah 1993; Hammani et al., 2009). In the case of the Tadla and Souss irrigation scheme in Morocco, farmers were shown to have a reasonable idea about functioning of the aquifers and the water balance (Bekkar et al., 2009). They were able to put in place defensive farm strategies through collective access to save water when problems with groundwater exploitation occurred. Ghazouani et al. (2012) also demonstrated that farmers are reasonably aware of the constraints of Nefzawa oasis in the south of Tunisia environment due to their long-term practical experience. In the Amman-Zarqa basin (Jordan), farmers have expressed a degree of willingness to be part of a collaborative water management process. The participatory process helped them to present several practical options that were discussed with decision makers, private sector, and NGOs such as the establishment of an irrigation advisory service, buying-out farm wells, limiting groundwater abstraction, exchanging treated wastewater for groundwater, and increasing the efficiency of municipal and industrial water use (Chebaane et al., 2004).

Brainstorming sessions and stakeholder workshops are often characterised by a wide variety of different views due to a wide range of users and different management approaches and priorities. While this is a potential richness for the meetings, it may also hamper consensus and a common view on the problem. Although available data are often not sufficient for detailed analysis, they do allow for simple back-of-the-envelope calculations that may guide the selection of realistic options and the definition of a window of opportunities. In this study, we explore the use of available data for back-of-the-envelope calculations to make a first cut between feasible and non-feasible solution pathways. We will first present a conceptual framework after which we will provide an example of an explorative study from Jordan.

\subsection{Conceptual framework}

Managing common natural resource such as groundwater typically involves cooperation of a range of different actors at different levels (from farmers at the lower scale level up to policy makers at the national level) but also from different sectors (representing agriculture, 


\section{Chapter 4}

industry, and municipalities). Different actors have different views on potential solution pathways to find a feasible solution for environmental problems between different related actors, and national dialogues, meetings and workshops are often organised. However, during meetings a plethora of potential interventions are generally suggested, reflecting differences among the participants in term of worldview, priority, knowledge and awareness of the problem, and ability to adopt changes. However, it is important to realize that not all the options that are considered by the stakeholders are realistic or will work in practice. Lemon (1999) distinguishes between the so-called decision space and opportunity space. The decision space is defined as the joint set of options that are considered by all the stakeholders. Theoretically, the opportunity space is the set of options that solve the problem. In practice, these options of course need to be tested for implementation and feasibility. Typically, the decision space and the opportunity space do not fully overlap. Three different categories of options can be distinguished:

- Options that are considered by the stakeholders and that will actually work. This is the intersection between the decision space and the opportunity space and defined here as the window of opportunity.

- $\quad$ Options that are considered by the stakeholders but that are not feasible solutions, this is the part of the decision space that does not overlap with the opportunity space, and

- $\quad$ Options that are feasible but that are not considered by the stakeholders, either because they are not aware of them or reject them for some reason.

Explorative studies to map and delineate the set of feasible solutions (window of opportunity) taking into account the biophysical, cultural and environmental constraints, before any meeting, can help in focusing the problem and highlighting the feasible available options. A quick, back-of-the envelop, analysis on the basis of available data and literature may help to define the opportunity space by considering factors and indicators. In the case of groundwater management, such an analysis may lead to an assessment of, for example, the recharge of the catchment, safe yield, water used, the (current and potential) agricultural area, the population living in the catchment and the elasticity of change adoption. More detailed research allows to narrow down the opportunity space to get a closer view about the introduced feasible management options. This allows us to define in more detail the window of opportunity.

We define the set of options by a particular actor as his decision space. Different actors have different decision spaces as their views, aims and goals differ. For example, farmers at the farm level might aim at increasing his farm revenue while policy makers at ministry level aim at conserving the aquifer or at least extending its lifetime. Farmers typically have a decision space at the farm level whereas a water board or a ministry may define a decision space at the regional scale. As a result, their decision spaces do not necessarily overlap. To properly compare and evaluate the decision spaces, it is necessary to aggregate them into a joined decision space.

Ideally, the decision space and opportunity space coincide, but reality shows that the two spaces typically only partially overlap (Lemon, 1999) (Figure 4-2). Explorative studies help in defining both space and define where they both overlapped to get closure of the window of opportunity for natural resource management. 


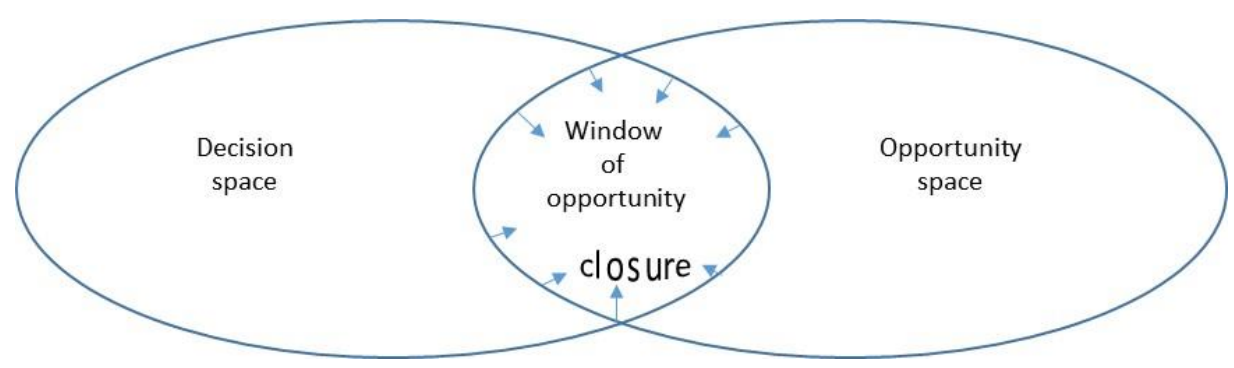

Figure 4-2. Conceptual layout for windows of opportunities

A number of global databases illustrate the growing availability of data. Various digital elevation models provide topographic information. For most parts of the world, data from the Shuttle Radar Topography Mission (SRTM) provide elevation data at a 30-90m resolution (Jarvis et al., 2008). The GTOPO30 database (http://edcdaac.usgs.gov/gtopo30/gtopo30.asp) is available for the entire globe at a resolution of 30 arc-minute. Recently, this database was updated into the Global Multiresolution Terrain Elevation Data 2010 (GMTED2010) as described by Danielson and Gesch (2011). These digital elevation models allow to study the topography of terrain, identify watersheds, and calculate e.g., the topographic wetness index (Sørensen et al., 2006). Climate data are available at a 30 arc second resolution from, for example, WorldClim (Hijmans et al., 2005). In addition, the reanalysis project (https://reanalyses.org) provides a range of datasets describing weather conditions at a high spatial and temporal resolution (e.g., Uppala et al., 2005). A rapid increase in global soil maps area available including the Harmonized World Soil Database (FAO/IIASA/ISRIC/ISSCAS/JRC, 2009), SoilGrids (Hengl et al., 2014), and S-World (Stoorvogel et al., 2017). Although soil data often lack details on soil physical characteristics they do provide enough information to derive hydrological data (like infiltration capacity or water holding capacity through pedotransfer functions; Gijsmans et al., 2007). Land use data is available as classified maps (e.g., Global Land Cover Characteristics Database; Brown et al., 1999) or basic data on vegetative cover from readily available satellite images from, e.g., SPOT. These data provide general information on climate, topography, land use, and soils to carry out some basic calculations for any location at the earth' surface. The data have become readily available through a range of different data portals either disciplinary (https://reanalyses.org for weather data and http://www.isric.org/explore for soil data) or more general purpose (worldgrids.org and https://earthexplorer.usgs.gov). In addition, local data and an increasing amount of literature may provide additional site-specific data.

The data and data portals allow us to provide detailed insight in most main aquifers. Using this data and information can help give a general idea or/and assess environmental problem boundaries before any field visit or farmers meeting and delineate feasible management options. Subsequently, a limited number of selected potential interventions with a certain elasticity can be evaluated in a more thorough manner in predictive studies that may involve additional data collection. 


\section{Chapter 4}

\subsection{Case study}

\subsubsection{Introduction}

This study focuses on the Azraq Basin, one of the Jordanian aquifers that is suffering from over-abstraction. The total area of the basin is $12,710 \mathrm{~km}^{2}$ with the larger part of the catchment (94\%) falling in the North-eastern part of Jordan, and smaller parts in Syria (5\%) and Saudi Arabia (1\%) (El-Naqa, 2010; Abdulla et al., 1999, Shahbaz and Sunna, 2000). Part of three Jordanian governorates are located inside the Azraq basin Jordanian's borders: Zarqa governorate represented by Azraq district, Mafraq governorate represented mainly by a part of North Badia district and Amman Capital governorate represented mainly by a part of $\mathrm{Al}$ Jiza district (Figure 4-3). Our study focused on agriculture activities in Azraq (Al Zarqa governorate).
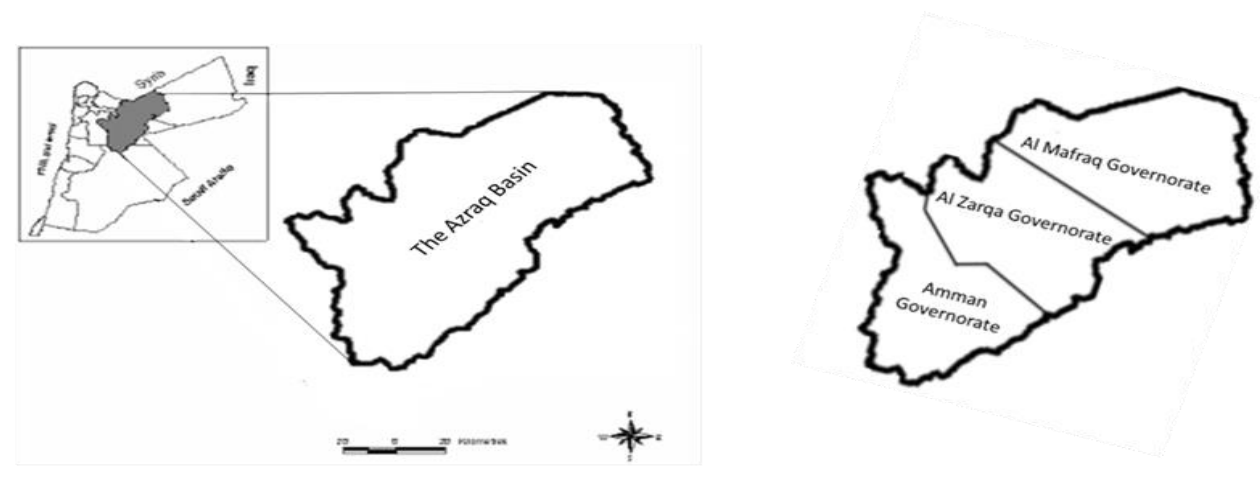

Figure 4-3. Azraq basin location (left) and the three governorates inside Azraq basin, Jordan

The basin consists of three aquifer systems that are hydraulically connected in certain parts: upper, middle and deeper aquifer systems. The groundwater flow is from south Syria towards Jordan and the groundwater moves from all directions towards the Azraq depression (Figure 4-4). Topographically, the basin is concave with the Azraq Oasis as a large fertile mudflat in the central and lowest part of the basin. The depth of groundwater in the upper aquifer varies from a few meters in the centre of Azraq oasis to $400 \mathrm{~m}$ due to topography in the northern catchment area. The middle aquifer system is considered as a confined aquifer throughout the basin, and it is recharged mainly from the Jabal Al Arab recharge area in the north of the basin. The deeper aquifer system has a low yield and poor water quality and is therefore of lesser importance. The main recharge of the upper aquifer system originates from infiltration through the basalt aquifer from high rainfall areas in Jabal Al Arab in southern Syria. Intensive thunderstorms and flash floods in the Azraq basin also contribute to a minor groundwater recharge. The estimated total recharge is about $34 \mathrm{Mm}^{3} /$ year $(\mathrm{MWI}$, 2010). 

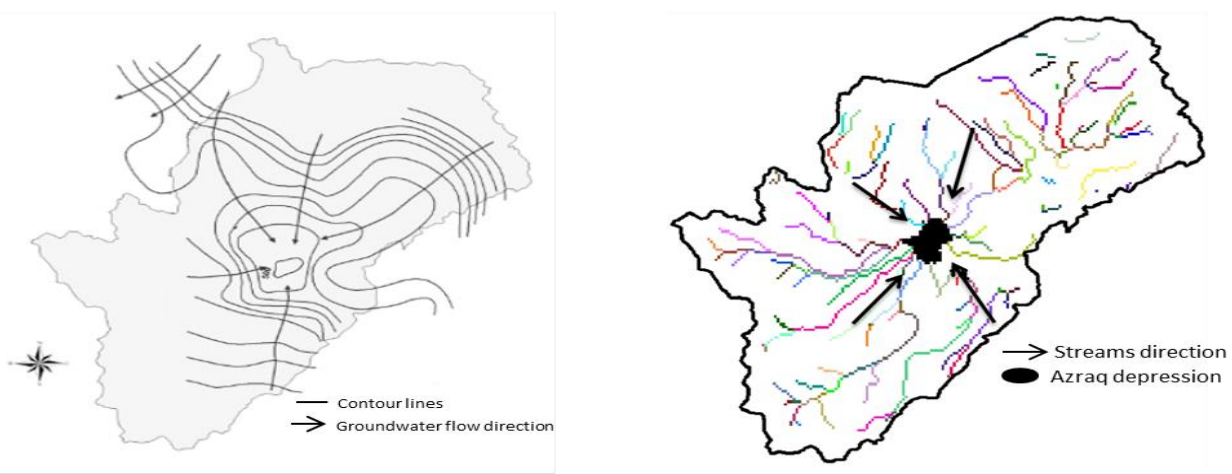

Figure 4-4. Azraq basin contour lines with groundwater flow direction in Azraq basin (left) and groundwater stream flow direction towards Azraq depression (right)

Azraq basin is a semi desert area characterized by a hot and dry summer and fairly wet and cold winter. The mean annual rainfall ranges from $50 \mathrm{~mm} / \mathrm{yr}$ in Azraq Oasis area to 500 $\mathrm{mm} /$ year in Jabal Al Arab area. The average precipitation for the entire basin is $87 \mathrm{~mm} /$ year, which occurs between January and March. Rainfall pattern of Azraq basin inside the Jordanian territory is $100-150 \mathrm{~mm}$ in the west and north of the basin, $50-100 \mathrm{~mm}$ in the middle of the basin and less than $50 \mathrm{~mm}$ in the south and east of the basin (JMD, 2011). The mean daily temperature in winter is less than $10^{\circ} \mathrm{C}$ and the maximum temperature is $45^{\circ} \mathrm{C}$. The potential evaporation rate in the area is $2400 \mathrm{~mm} / \mathrm{yr}$. The dominant soil type in the region is a silty clay loam soil, high soluble salt content in the subsurface horizon, soils are primarily composed of limestone or covered by basalt boulders that resulted from volcanic out crossing centred on Jabal Al Arab (DLU, 1994).

Groundwater in Azraq basin is a major source of water for domestic use for the cities of Amman and Zarqa as well as the Azraq area itself, government abstracts about $23 \mathrm{Mm}^{3}$ of Azraq basin groundwater every year for domestic purposes and only $0.35 \mathrm{Mm}^{3}$ for industrial purposes. The abstraction for both uses are already equal the basin safe yield, taken at 24 $\mathrm{Mm}^{3}$ per year (MWI, 2009). Irrigated agriculture is based on groundwater abstraction and is the main consumer of water in the basin. The Ministry of water and irrigation officially announced an abstraction of $28 \mathrm{Mm}^{3}$ of water per year for agriculture purposes, which is nearly equivalent to the entire safe yield of the basin. Table 4-1 presents the abstraction rate according to the purpose of use of registered legal wells, knowing that Azraq has three types of functioning wells: legal wells, illegal registered wells, and illegal not registered wells.

Groundwater-based agriculture has been developed in Azraq basin since the 1960s driven by the improvement in well-drilling techniques, the decrease in energy costs, land affordability and accessibility, and good water quality and quantity (Molle et al., 2017a). Olive and stone fruit trees were the main dominant cultivated crops in the basin.

The expansion in cultivated area was encouraged by the government who freely awarded licenses for wells in the 1980s and early 1990s. Sensing the increase in groundwater use in the area in the late 1980s, the government tried to control abstraction by introducing special laws for groundwater use, with measures and tools to control abstraction, including banning new wells, introducing metering, water tariff, restriction areas and control of drillers. 


\section{Chapter 4}

However, abstraction continued to increase, and so did the number of illegal wells; the agricultural area expanded and groundwater became over-abstracted.

Table 4-1. Groundwater usage in Azraq basin from the registered legal wells during 2009 (MWI, 2009)

\begin{tabular}{|l|c|c|c|}
\hline & Abstraction rate $\mathrm{Mm}^{3}$ & Safe yield $\mathrm{Mm}^{3}$ & \multirow{2}{*}{ Abstraction rate \% } \\
\hline Private drinking wells & 0.32 & & \\
\cline { 1 - 3 } Governmental drinking wells & 23.00 & & \\
\cline { 1 - 3 } Industrial purpose & 0.35 & & \\
\hline Agricultural purpose & 28.00 & & \\
\hline Rural area & 0.09 & 24 & $215 \%$ \\
\hline Total & 51.76 & & \\
\hline
\end{tabular}

The development of agricultural has continued with the introduction of new crops such as grapes and pomegranates, diversifying away from traditional olive trees. More recently, farmers have attempted to cultivate alfalfa due to its high yield and high revenue, despite its high-water consumption.

Farming in Azraq was considered as a prime investment option, and investors and local farmers enjoyed a good economic return from these activities. According to the Ministry of Agriculture, cultivated land surface increased between 2005 and 2011 from 61,200 du to 114,320 du (MoA, 2012).

The intensive pumping carried out through the last 20 years in the Azraq basin has caused a lowering of the basin's water table, and the drying up in 1993 of the four natural springs in the middle of the Azraq oasis that had discharged good quality water for thousands of years, spurring wildfires across the increasingly dry environment (Al Zu'bi, 2001). The lowering water table of the basin, in turn, has encouraged deeper excavation of wells that once provided large outputs of water for irrigation, which contributed to lowering and degrading the water table even further, increasing salinity and degradation in water quality. Empirical studies conducted by the Azraq Oasis Conservation Project (Al-Eisawi, 1995) indicated the presence of three problems related to agriculture activities in the basin: i) a large percentage of high quality water is consumed by low value crops, ii) soil deterioration due to the combined effects of fertilizers, and high evaporation, and iii) agriculture growing rapidly despite the unsustainable use of water (Al Zubi and Al Kharabsheh, 2003).

The overexploitation of the aquifer for both urban needs and irrigation resulted in an environmental catastrophe for the wetland ecosystem, abandon of unproductive lands, trebling of the salt content of the aquifer, declining land productivity and rangelands, and reduced tourism potential.

\subsubsection{Methodology}

The methodology aims at defining the opportunity space, decision space and window of opportunity. To define the opportunity space, we collected available data from different sources. The main available data from the literatures and official documents that were used are: safe yield, recharge, cropping pattern, type of irrigation system, irrigation system efficiency, decline in water table, current trend of groundwater use and cultivated area. The available data that were used and retrieved from the web are: 
- data on long term averages of total annual rainfall and mean annual

temperatures at a 30 arc-sec resolution from WorldClim,

- a digital elevation model from Aster at a $30 \mathrm{~m}$ resolution, and

- a range of land cover maps at different resolutions derived from satellite imagery.

Two types of analysis were elaborated to define the opportunity space: the first analysis includes a spatial data analysis for the Azraq basin using freely accessible GIS data on climatic conditions (Figure 4-5), elevation (Figure 4-6), land cover and Google imagery (Figure 4-7).

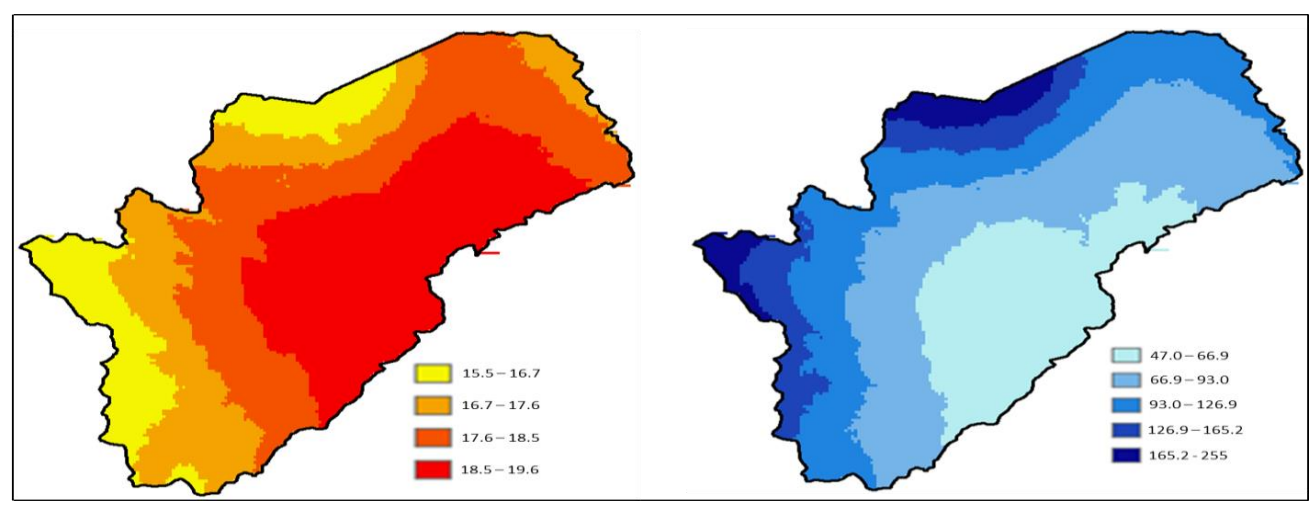

Figure 4-5. Mean annual temperature in ${ }^{\circ} \mathrm{C}$ (left) and annual precipitation in $\mathrm{mm}$ (right) in Azraq basin

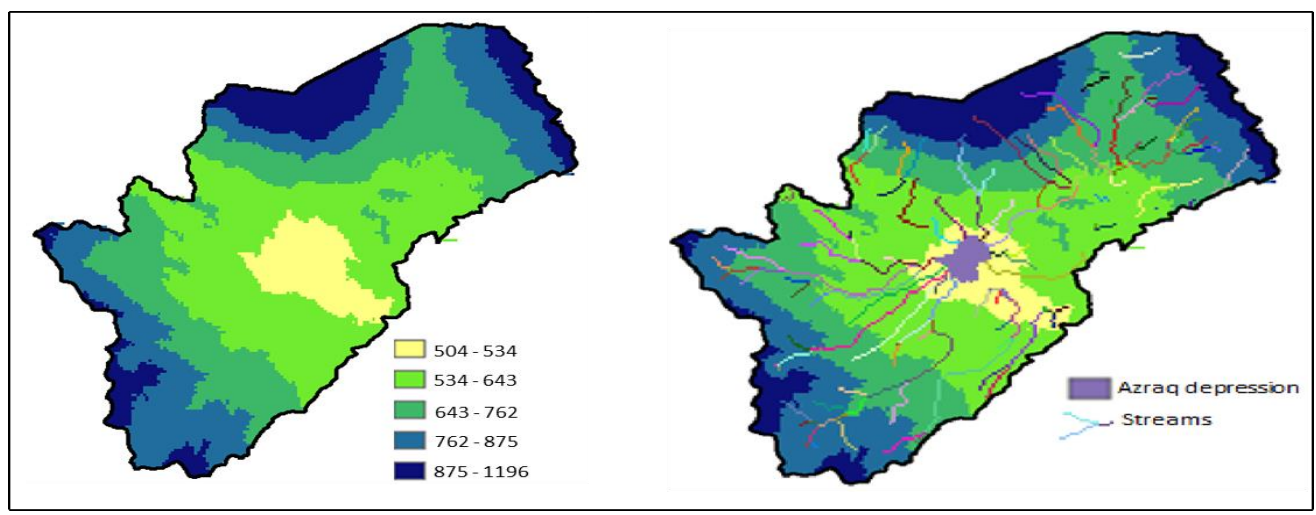

Figure 4-6. Elevation map (left), streams link and Azraq depression area with elevation map for Azraq basin (right)

The extent of the watershed was identified using the digital elevation model in a hydrological analysis in ArcGIS (including an analysis of flow direction, flow accumulation, streams and watersheds). In addition, rainfall data were analysed using the official boundary of the watershed in combination with the WorldClim database. Finally, the cultivated area in the 


\section{Chapter 4}

watershed is estimated using various global land cover maps based on satellite imagery. In the second analysis, groundwater abstraction was estimated using the areas of different cultivated crops, their water requirements cultivated areas and the drop in the water table. The governmental data on the various properties were also included in the analysis

The decision space was defined on the basis of the proposed intervention of different stakeholders that are presented in the study area: the water authority of Jordan (WAJ), farmers, local people (not necessarily farming), Azraq Oasis wetland, and NGOs which work with different initiatives in the area.

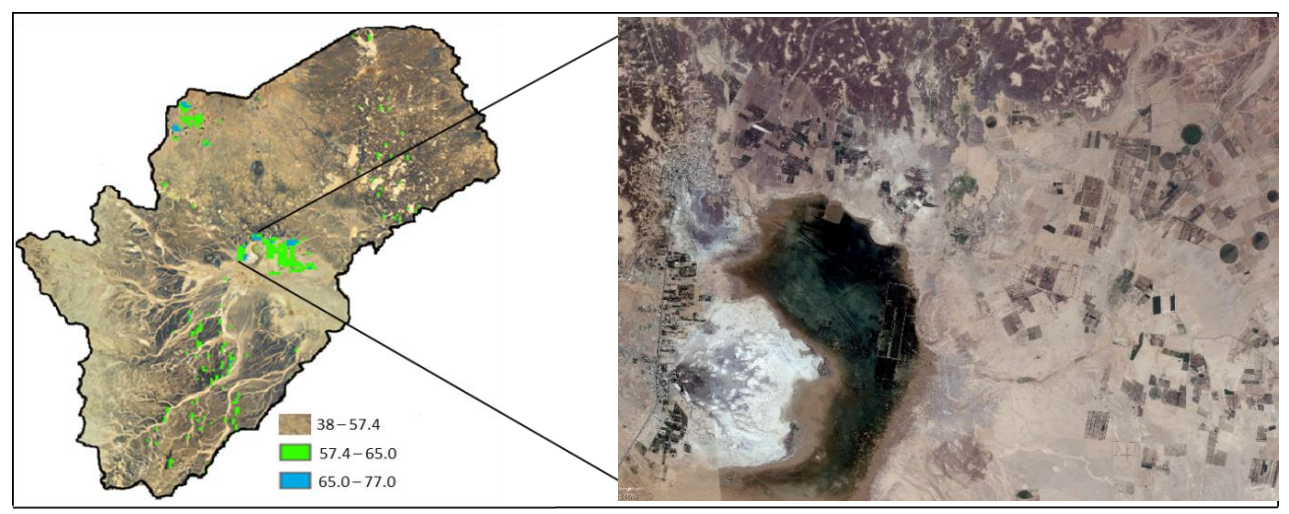

Figure 4-7. NDVI map for Azraq basin (left) and reflection of agriculture land near Azraq depression using Google earth map (right)

The window of opportunity was defined as the overlap between opportunity space and decision space.

\subsubsection{Results and Discussion}

\subsubsection{Opportunity space}

With the publically available data, four different elements were explored, including the extent of the watershed, total annual rainfall, and the extent and location of the cultivated area

\section{Extent of the Azraq watershed}

The extent of the Azraq watershed is often considered to be a given. However, different sources of information provide us with very different estimates. The extent that is typically being used is $12,710 \mathrm{~km}^{2}$. The commonly used GIS map indicates a small difference of $2.3 \%$ and covers an area of $12,414 \mathrm{~km}^{2}$. The limits of the watershed derived from the ASTER global digital elevation model provide a very different surface area covering an area of 10,601 $\mathrm{km}^{2}$ or $16.6 \%$ less than the commonly used area.

\section{Rainfall amount}

JMD (2010) provides general information on rainfall quantities in the watershed. They indicate that the total annual rainfall varies in the watershed between 50 and $500 \mathrm{~mm} / \mathrm{yr}$ 
with an average of $87 \mathrm{~mm} / \mathrm{yr}$. This numbers are estimates based on a limited number of observations. The WorldClim database interpolated the weather station information using ANUSPLIN to interpolate the noisy multi-variate data using thin plate smoothing splines with latitude, longitude, and elevation as independent variables (Hijmans et al., 2005). An overlay of WorldClim and the GIS map of the Azraq basin indicates that the total annual rainfall varies between 47 and $310 \mathrm{~mm} / \mathrm{yr}$ with a weighted average of $101 \mathrm{~mm} / \mathrm{yr}$.

\section{Cultivated area}

The Jordanian Ministry of Agriculture indicates that around $104 \mathrm{Km}^{2}$ is cultivated in the Azraq basin in 2010. Other sources of land cover gave significantly lower estimates of the cultivated area. The GlobCov database indicates that only $8 \mathrm{~km}^{2}$ whereas MODIS indicates a cultivated area of $3 \mathrm{Km}^{2}$ in the Azraq basin. The low estimates with the satellite imagery are probably underestimates. With the relative course spatial resolution the cultivated area is underrepresented as the very small parcels are not being recognized.

\section{Locating the agriculture area}

Locating the agriculture area was done using NDVI maps in combination with Google earth imagery. The NDVI can be used as a good indicator of the vegetative cover, but does not indicate whether it is natural or cultivated. The latter can easily be confirmed with the Google earth imagery. The majority of the watershed is covered by desert and rangeland. Less than 1 $\%$ of the basin has intensive agriculture and human activities which are mostly located near the Azraq depression area. This area is the lowest part in the basin (500m asl) where groundwater is available a few meters below the surface. This is reasonable according to the presented climatic conditions in the basin. This result has a good reflection with the agriculture land that appears on Google Earth map.

\section{Estimation of groundwater abstraction}

The Ministry of Agriculture indicated that the cultivated area in Azraq covers 10,429 ha $(0.82 \%$ of the basin) with vegetables, forage, fruit tree, grape and mainly olive trees (MoA, 2010). Groundwater is the only source of irrigation in the district. In the Azraq basin four irrigation systems are used that differ in their water use efficiency: surface irrigation with an efficiency of $55 \%$, open tube irrigation with an efficiency of $65 \%$, micro spray or Virojet irrigation with efficiency of $60 \%$ and drip irrigation with an efficiency of $70 \%$ (Table 4-2).

Net crop water requirements have been estimated for the actual cropping pattern in Azraq area (Venot et al., 2007, Fitch, 2001, Hanson, 2000 and Demilecamps, 2010). The total abstracted water was calculated based on the official data for cultivated area multiplied by the crop water requirement (CWR).

The results are presented in Table 4-3. The total calculated abstracted groundwater equals $74 \mathrm{Mm}^{3} / \mathrm{yr}$, which exceeds two and a half times the annual abstraction rate documented by the Ministry of Agriculture $\left(28 \mathrm{Mm}^{3} / \mathrm{yr}\right.$ ). The official abstraction rate combined with the official cultivated area would result in a water use of $160 \mathrm{~mm} / \mathrm{yr}$, which does not correspond to the cultivated cropping pattern. With the calculated abstraction of $74 \mathrm{Mm}^{3} / \mathrm{yr}$, the water consumption is around $700 \mathrm{~mm} / \mathrm{yr}$ which is considered more realistic with the presented cropping pattern (mainly trees and alfalfa) and the climatic conditions. The large gap between the calculated groundwater usage and the official numbers can be caused by illegal 


\section{Chapter 4}

groundwater use. The Ministry of Agriculture, and/or the Ministry of Water and Irrigation calculate groundwater abstraction on the basis of legal wells only.

Table 4-2. Irrigation system types and efficiency in Azraq basin

\begin{tabular}{|l|c|c|c|c|}
\hline Irrigation system & Surface & Open tube & Virojet & Dripper \\
\hline Irrigation system efficiency & $55 \%$ & $65 \%$ & $60 \%$ & $70 \%$ \\
\hline
\end{tabular}

Table 4-3. Estimated net crop water requirement for the actual cropping pattern in Azraq basin

\begin{tabular}{|c|c|c|c|c|}
\hline \multicolumn{2}{|c|}{ Fruit tree } & \multirow{2}{*}{$\begin{array}{c}\text { Area in du } \\
280\end{array}$} & \multirow{2}{*}{$\begin{array}{c}\text { Net CWR m }{ }^{3} / \mathrm{du} / \mathrm{yr} \\
1000\end{array}$} & \multirow{2}{*}{$\begin{array}{c}\text { Net } \mathrm{CWR} \mathrm{m}^{3} / \mathrm{yr} \\
280000\end{array}$} \\
\hline Apple & Fruit & & & \\
\hline & No & 165 & 1060 & 174900 \\
\hline \multirow[t]{2}{*}{ Peers } & Fruit & 970 & 800 & 776000 \\
\hline & No & 820 & 1000 & 820000 \\
\hline \multirow[t]{2}{*}{ Quince } & Fruit & 200 & 800 & 160000 \\
\hline & No & 0 & & \\
\hline \multirow[t]{2}{*}{ Peach } & Fruit & 50 & 900 & 45000 \\
\hline & No & 40 & 1040 & 41600 \\
\hline \multirow[t]{2}{*}{ Apricot } & Fruit & 150 & 900 & 135000 \\
\hline & No & 50 & 1040 & 52000 \\
\hline \multirow[t]{2}{*}{ Cheery } & Fruit & 50 & 800 & 40000 \\
\hline & No & 90 & 1000 & 90000 \\
\hline \multirow[t]{2}{*}{ Pomegranate } & Fruit & 650 & 800 & 520000 \\
\hline & No & 200 & 1000 & 200000 \\
\hline \multirow[t]{2}{*}{ Palm } & Fruit & 450 & 600 & 270000 \\
\hline & No & 1130 & 500 & 565000 \\
\hline Others & & 40 & 1040 & 41600 \\
\hline \multirow[t]{2}{*}{ Sum } & Fruit & 2800 & & 4211100 \\
\hline & No & 2535 & & \\
\hline \multicolumn{5}{|l|}{ Vegetables } \\
\hline \multicolumn{5}{|c|}{ Winter Vegetables } \\
\hline \multicolumn{2}{|c|}{ Tomato } & 2000 & 450 & 900000 \\
\hline \multicolumn{2}{|l|}{ Eggplant } & 750 & 250 & 187500 \\
\hline \multicolumn{2}{|l|}{ Zucchini } & 150 & 300 & 45000 \\
\hline \multicolumn{2}{|l|}{ Pepper } & 250 & 250 & 62500 \\
\hline \multicolumn{2}{|l|}{ Cauliflower } & 1500 & 450 & 675000 \\
\hline \multicolumn{2}{|l|}{ Cabbage } & 1700 & 450 & 765000 \\
\hline \multicolumn{2}{|l|}{ Green beans } & 50 & 300 & 15000 \\
\hline \multicolumn{2}{|l|}{ Onion } & 320 & 320 & 102400 \\
\hline \multicolumn{2}{|l|}{ Garlic } & 100 & 350 & 35000 \\
\hline \multicolumn{2}{|l|}{ Others } & 120 & 400 & 48000 \\
\hline \multicolumn{2}{|c|}{ Sum } & 6940 & & 2835400 \\
\hline \multicolumn{5}{|c|}{ Summer Vegetables } \\
\hline Tomato & & 500 & 550 & 275000 \\
\hline Eggplant & & 350 & 300 & 105000 \\
\hline Zucchini & & 40 & 350 & 14000 \\
\hline Pepper & & 20 & 280 & 5600 \\
\hline Cauliflower & & 500 & 500 & 250000 \\
\hline Cabbage & & 500 & 500 & 250000 \\
\hline Water melon & & 750 & 400 & 300000 \\
\hline
\end{tabular}


Chapter 4

\begin{tabular}{|l|c|c|c|}
\hline Melon & 750 & 500 & 375000 \\
\hline Onion & 50 & 400 & 20000 \\
\hline Garlic & 100 & 450 & 45000 \\
\hline Okra & 50 & 550 & 27500 \\
\hline Sum & 3610 & 1667100 \\
\hline Winter Cereal & 450 & 450 & 202500 \\
\hline Wheat & 3000 & 450 & 1350000 \\
\hline Barley & 6000 & 500 & 3000000 \\
\hline Others & 9450 & & 4552500 \\
\hline Sum & 73330 & 750 & 54997500 \\
\hline Olives & 5620 & 1040 & 5844800 \\
\hline Grape & 104285 & & 74.1084 \\
\hline Total water consumption MCM/yr & \\
\hline Total cultivated area in du &
\end{tabular}

In order to monitor the groundwater table and water quality, the Water Authority of Jordan (WAJ) dug sixteen monitoring wells in a preserved area in Azraq (the, so-called, AWSA field). As the number of functioning deep wells has been increasing, the abstracted amount has also been increasing, causing a decrease in water table levels by approximately 25 meters during the last 25 years (Figure 4-8). Farmers interviews by Demilecamps (2010) indicated that the over exploitation of groundwater area led to a drop of the groundwater table by 1 to $3 \mathrm{~m} / \mathrm{yr}$. Farmers that settled in the 1980s testified during fieldwork visits between 2013 and 2015 to a drop in the groundwater table of around 25 meters since the 1990s. The same result has been confirmed also by HCST (1999).

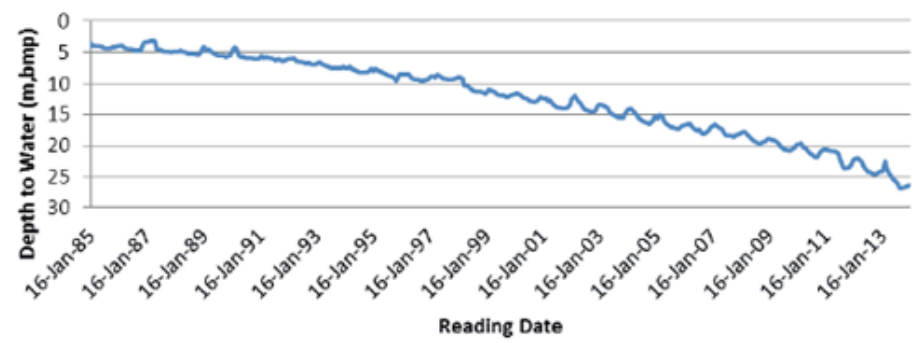

Figure 4-8. Fluctuation in groundwater table in Awsa field, Azraq (WAJ, 2014)

The agriculture area in Azraq Governorate, as reported in the Ministry of agriculture's annual report, equals $104 \mathrm{~km} 2$. Given the fact that agriculture completely relies on groundwater, water requirements in the area roughly equal groundwater abstraction. As a result one expects a groundwater abstraction of roughly $104-312 \mathrm{Mm}^{3} /$ year. Alternatively the abstraction can be calculated on the basis of the drop of the groundwater table. Assuming a porosity of $20 \%$ in the aquifer, the amount of abstracted groundwater abstracted varies between $20-60 \mathrm{Mm}^{3} /$ year. However, the actual abstraction of the ground water could be higher if groundwater flows laterally to the agricultural area.

\subsubsection{Decision space}

An inventory done by stakeholders resulted in a list of options to regulate over-abstraction of groundwater in Azraq basin. The options are oriented towards regulations, the supply of 


\section{Chapter 4}

groundwater, managing water demand and community co-management (Table 4-4). The options differ additionally in their scale level, whereby some focus on the farm level and others on the aquifer level. Some of these options are feasible as they align with the current environment represented by the opportunity space. However, some of the options clearly lie outside the opportunity space.

Table 4-4. Alternative options for groundwater management in the Azraq region

\begin{tabular}{ll}
\hline Regulatory tools & $\begin{array}{l}\text { Policy tools and measures: selling wells, water tariff, well permits and } \\
\text { licenses, control agriculture area expansion, subsidies }\end{array}$ \\
Supply management & $\begin{array}{l}\text { Alternative source of water: desalination, treated wastewater, water } \\
\text { transfers, artificial recharge }\end{array}$ \\
& $\begin{array}{l}\text { New source of income: solar energy } \\
\text { Demand management }\end{array}$ \\
& Saving water: cropping patterns, awareness campaigns \\
& Reduce water loss: irrigation efficiency \\
Community co-management & \\
\hline
\end{tabular}

Regulatory tools include several options to be implemented at the aquifer level by policy makers. Supply and demand management include options to be implemented at both farm and aquifer levels and originate from stakeholders at different scales (including the government, farmers, and NGOs). While the community co-management of groundwater resources in Azraq basin is an option to be implemented at aquifer level were multi-scale level stakeholder contribute to water management jointly with the policy makers.

\subsubsection{Window of opportunity; discussion on potential solutions}

The exploratory analysis in this study provided new insights on the extent of the Azraq basin, the cultivated area and actual groundwater abstraction for agriculture, improving our knowledge about water requirements and the depletion of the aquifer. The analysis aims to identify feasible management options of the scarce groundwater resources. Ideally, the opportunity space should include or introduce a range of options to conserve the basin between the safe yield and recharge. But the results clearly show that current consumption is far away from both. Groundwater abstracted for domestic and industrial use already equals the entire safe yield of the basin. Accordingly, the boundaries of the opportunity space had to be redefined. The boundaries were extended considering a target to decrease the abstraction down to a theoretical allowable abstraction rate that will increase the aquifer lifetime instead of sustaining it. Stakeholders introduced a number of interventions into the decision space that help in reducing the current abstraction of groundwater, thus extending the aquifer life time. To achieve this goal, technical packages of regulatory tools, supply and demand management measures and co-management should be applied jointly to achieve an overlap between opportunity and decision spaces i.e., the window of opportunity.

Some of the management options will be located in the opportunity space without overlapping with the decision space, since the stakeholders did not mention them, are not aware of them, or rejected them. Some of the management options will be located in the decision space despite the fact that they are not feasible with regards to the time scale or the current environment. Other options will lie at the intersection, that is within the window of opportunity. Regulatory management can decrease groundwater use. The result of using this approach can be observed at both short- and long-term time scale. The short-term options 
are more likely to be included in the window of opportunity while the long-term options are more frequently located in the decision space due to time constraints. For example, the buying-out of wells by the government will decrease groundwater consumption instantly. Both government and farmers can gain from such an initiative as the government can control their use and extend the lifetime of the exhausted resources, while farmers will get financial compensation allowing them to start new alternative activities outside agriculture. Alternatively, subsidies to encourage cropping patterns with reduced water consumption, or a new activity like solar energy production, will also help in decreasing the pressure on the groundwater resource: the effects can be noticed shortly and fit well in the window of opportunity. The results of managing groundwater resource through controlling illegal wells by introducing well licences, permits and water tariff are normally observed in the long run, as it is always linked with social constraints and the willingness of users to obey the laws and of the government to implement it. Decreasing the agricultural area and limiting the expansion of already existing areas help in reducing water consumption, even if this is made difficult due to social issues, especially for farmers who only depend on their farm outcome for a living. Therefore, these options are more likely to lie within the decision space.

Demand management introduce feasible and achievable options to decrease the pressure on groundwater resource and extend its lifetime. These options are more likely to be adopted by users compared with regulatory tools options and they are more likely to be included in the window of opportunity. For example, increasing irrigation system efficiency by adopting new irrigation techniques helps in reducing the water losses in the system, which will eventually lead to decreasing gross abstraction. The average efficiency of irrigation system in the area is $65 \%$, and increasing water use efficiency up to $95 \%$ would save $21 \mathrm{Mm}^{3} / \mathrm{yr}$ lowering gross crop water requirement from $74 \mathrm{Mm}^{3} / \mathrm{yr}$ to $53 \mathrm{Mm}^{3} / \mathrm{yr}$. However, such a technical change is unlikely to reduce net consumption (by ET) and might even increase it (Perry and Steduto, 2017; Molle et al., 2017). Changing the cropping pattern by introducing new crops with lower water consumption and good profitability is also considered as a feasible option to be implemented. Converting to new non-agricultural activity like producing solar or wind energy (green energy) will decrease the demand on groundwater resources, an extensive study should be done in the area before addressing this option. Demand management options will be more attractive to users if paralleled with government subsidies for buying new irrigation systems, supporting less water consuming crops, or decreasing the cost of solar energy equipment. Supply management normally means providing users with new sources of water to meet their needs, which will decrease their current reliance on groundwater: they include treated wastewater, water transfer, desalination of brackish water and artificial recharge. All these options depend on government decisions and will be available if the social, economic, and physical environment allows that. These options are more likely to be located within the opportunity space, as normally decision makers are not aware of, or think it is not feasible or a priority, or don't want to implement them due to political constraints. Co-management is often ignored by governmental parties as it needs institutional reforms before it can be adopted and bureaucrats usually do not favour such an option.

It is useful to add that the options introduced above might be considered as feasible for some users but not for others. For example, subsidies are a good option to motivate farmers to change their behaviours toward water use, but policy makers might look at it as an encouragement to further expansion of current agricultural activities. The limitation of and decrease in the agricultural area, as well as closing illegal wells, might be feasible options 


\section{Chapter 4}

from the policy maker point of view. However, these options might affect farmers negatively if they are not implemented in a way that does not affect the farmers' revenue and economic situation. Some of the options are easy to implement. However, others are difficult to implement due to the social considerations and an economic dependency on the resource. Some of the options have a short-term effect while others have an effect in the long run. Actually, all options might be considered valuable, as there is not a fixed solution in management terms. Merging long and short-term effect options together and introducing them in meetings to policy makers and users to consider these options will decrease the gap in the decision space and help find an overlap with the opportunity space. Figure 4-9 shows a qualitative sketch of available options for groundwater management to achieve a longer aquifer lifetime in Azraq basin.

\subsection{General discussion}

The rapid increase of available data opens new opportunities. However, the results also clearly show that while in some cases the various data sources are in agreement, in other cases the different sources provide new insights and very different views. This confirms earlier results by e.g., Hendriks et al. (2015), which show that a wide array of different sources of soil information tell different stories about soil conditions in a study area in Kenya. The multitude of data can be used in different ways. Cross checking between different sources allows for the verification of data sources. Different sources can be used to indicate ranges or accuracies and be analysed in ensemble runs in which different data sources are evaluated (commonly used by climate change predictions). Finally, the data can differ because they were collected in different ways or with different assumptions. In the latter case, they may be complementary and provide additional information.

An explicit exploration of the decision space illustrates explicitly the multitude of options and opens the stage for discussion and selection of the common denominator amongst the stakeholders. However, the plethora of options may be overwhelming and hampering the discussion as well. As a result, intersecting the decision space with the opportunity space may provide a screening of the options and lead to better focus the discussion. In the case of the Azraq, the situation was found to be rather extreme. The opportunity space clearly did not intersect with the decision space and had to be redefined to extend the lifetime of the aquifer rather than conserve it. 


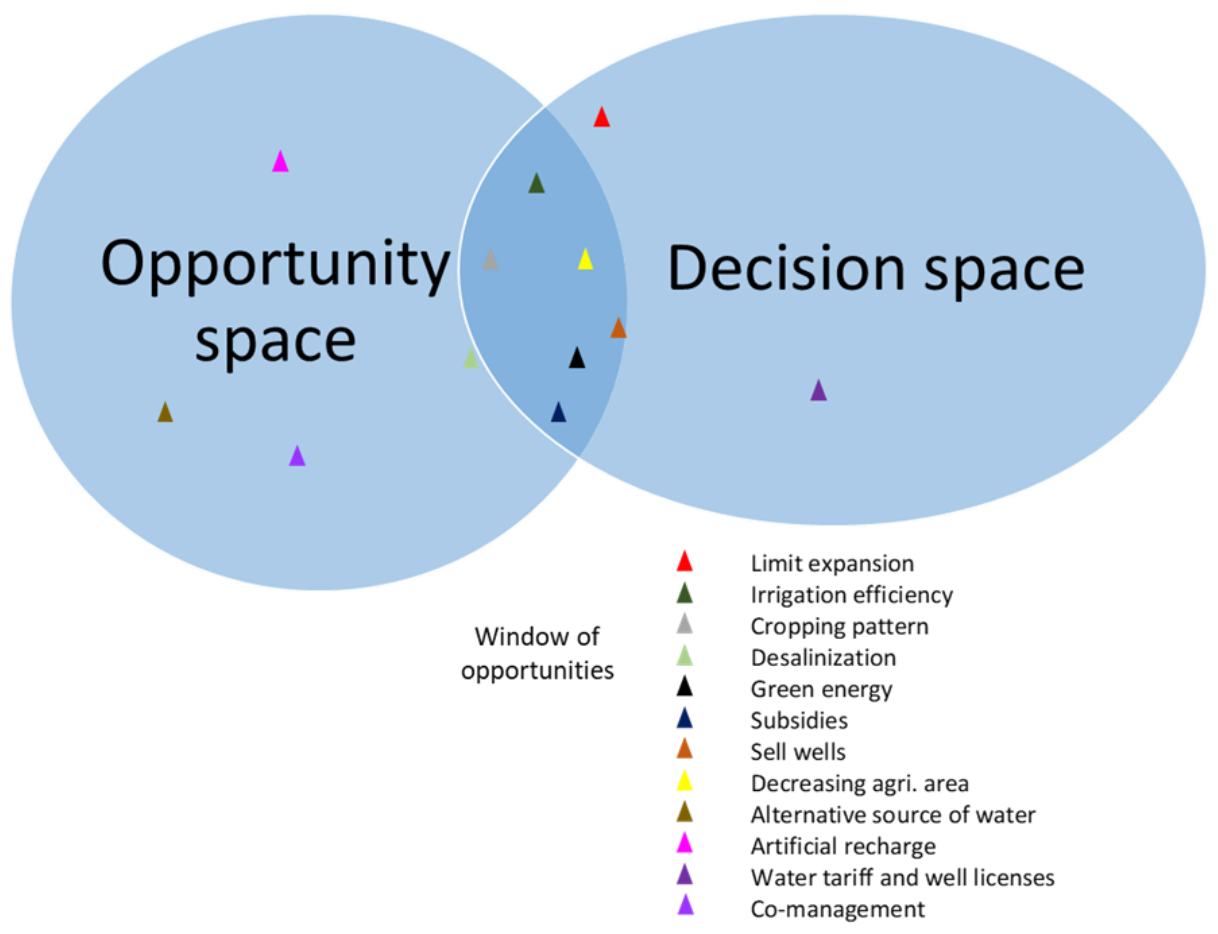

Figure 4-9. Window of ideal sustainable feasible solutions

\subsection{Conclusions}

Explorative spatial analysis using the rapidly increasing base of available accessible data, such as a high resolution digital elevation models, weather data, soil data, and land use maps, can help in selecting realistic options to define windows of opportunities for solutions to environmental problems. This may aid stakeholder meetings to better delineate the problem boundaries and the underlying causes of the problem, and facilitate the process of natural resources management. Subsequently the limited number of selected and potential interventions can be evaluated in a more thorough manner in predictive studies that may involve additional data collection.

Generally, a more focused problem definition does not necessary lead to a sustainable and feasible solution. Instead, it might highlight the gap between the actual situation and the ideal one from a management perspective. There are many disconnects between what is desirable for the area and what could be done in terms of management. This disconnection can be revealed through the spatial explorative analysis. This types of analysis supports, facilitates and focuses the stakeholder deliberations on natural resources management options. 



\section{CHAPTER FIVE}

\section{The Politics of Accessing Desert Land in Jordan}

Al Naber, M. and Molle, F. 2016. The politics of accessing desert land in Jordan. Land Use Policy, 59: 492-503. 



\title{
5 Chapter Five: The Politics of Accessing Desert Land in Jordan
}

\begin{abstract}
With the dramatic increase of the population in Jordan, the value of land has rocketed up. Urban sprawl into semi-desert or desert areas, initially not surveyed or settled by the British and considered as state land, has brought to the surface the problematic status of those lands. Likewise, the profitability of irrigated agriculture based on groundwater has generated a demand for land in the Mafraq, Zarqa and Amman governorates. These trends have spurred tensions between local tribes and the state. This study focuses on land tenure and conflicts in the semi-desert and desert areas of Jordan, with a focus on the expansion of irrigated agriculture within the Azraq basin. It is based on field work and interviews with different stakeholders at various levels. We first provide a summary of the main historical developments regarding land tenure in Jordan, with a focus on the status of semi-desert and desert land. We move on to examining the different ways by which state land can be privatized and then review instances of conflicts around rights to desert land in the past 30 years, further taking the Azraq water basin as a case study to shed light on the particular case of groundwater-based agricultural expansion. We then articulate our discussion through the lens of legal pluralism, look at the interplay between state and tribal power, and analyze the twin strategies of accessing land and water in desert areas. We conclude by showing the historical continuity of the land tenure relationships, while singling out Jordan's state land management regime.
\end{abstract}

Keywords: land tenure, legal pluralism, desert reclamation, tribal politics, Jordan, Azraq

\subsection{Introduction}

Arid rangelands or deserts are, at first sight, of little value. But in most of the Middle-East and North-Africa Region, necessity (urban expansion) and economic opportunities (e.g. groundwater-based irrigated agriculture, tourism or mining) are fueling an expansion of human settlements and activities into these hitherto neglected areas. This expansion and the associated generation of wealth, raise critical questions on land tenure and rights, challenge the category of 'state land' (Kelly and Peluso, 2015), and reignite tribal claims for desert lands (see for example Gertel et al., 2014 for Sudan, and Sims, 2015 for Egypt).

Although the gradual transfer of land to investors and developers is a widespread phenomenon that may occur through the land market, it thrives on weak land management administrations and procedures, fuzzy and unregistered land rights (see Mahdi, 2014 on Morocco, for example), but also on the mechanisms through which 'state land' can be appropriated, rented or privatized (Kelly and Peluso, 2015). This is particularly true in Arab countries where the 'state land' category may have been inflated by land nationalization and/or includes (often dominant) marginal/unused/desert lands. The interests of local dwellers, farmers or herders - who more often than not belie the concept of an 'empty space'- may be threatened by state projects or state-sponsored large (often foreign) companies, diffuse homestead building and commercial agriculture, or the claims of other local tribes, as observed by Casciarri (2015) in Sudan. State ownership and the ways state land may be privatized are often challenged (or contradicted) by the principle of wada yadd (direct reclamation of unused public land), where unchallenged and uninterrupted use of land during a certain time (typically 15 years) may open a right to ownership (like in Jordan (Madanat, 2010) or Egypt (Sims, 2015)). 


\section{Chapter 5}

Nowhere is the growing value of desert land better illustrated than in Jordan. With the dramatic increase of the population in the country, notably through the successive waves of Palestinian refugees $(1948,1967,1973)$, returnees from the Gulf (1991), Iraqis, and most recently Syrians - the value of land in Jordan has skyrocketed. Urban sprawl into semi-desert or desert areas, initially not surveyed or settled by the British or the Jordanian government and considered as state land, has brought to the surface the problematic status of those lands. In particular, the profitability of irrigated agriculture based on groundwater has generated a thirst for land in the Mafraq, Zarqa and Amman governorates, east of the Hijaz railway. These trends have spurred tensions between local tribes, claiming historic ownership of land, and a state unwilling, under the prevailing conditions of market boom and speculation, to give away what it considers as state ownership. This paper addresses the political tensions between the state and desert land appropriators, that speak not only to the future of the country's vast desert lands, the affirmation of state power, or the political stability of the regime, but also to the resulting overexploitation and future of Jordan's precious groundwater resources.

Most of the earlier studies on land tenure in Jordan have focused on settled areas (see for example, Palmer, 1999; Wahlin, 1994a, 1994b; Mundy, 1994, 1996), the Jordan Valley (Nims, 2005), or urban/peri-urban areas (with the work of Razzaz, 1992, 1993), with little work on disputed rangelands and deserts (Tarawneh, 1999, is an exception), especially in the past 15 years. This study contributes to filling the gap on this issue and focuses on land tenure and conflicts in the semi-desert and desert areas of Jordan, with a focus on the expansion of irrigated agriculture in the Azraq Basin. It is based on the collection of literature and newspaper articles on land tenure/conflicts in Jordan, interviews with 54 farmers/investors in this area, and semi-structured interviews of nine Key Informants from the Ministry of Agriculture, the Ministry of Irrigation and Water Resources, and the Department of Land Survey from 2013 to February 2015. Whether coming from farmers or officials, information on land transactions is frequently limited and often ad hoc (the reasons for which will become clear later). Because of the sensitivity of the topic and the reluctance of some interviewees to be cited, we anonymized reported information and quotes.

We first provide a brief summary of the main historical developments regarding land tenure in Jordan, with a focus on the status of semi-desert and desert land. We move on to examining the different modes by which state land can be privatized and then review instances of conflicts around rights to desert land in the past 30 years, further taking the Azraq Basin as a case study to shed light on the particular case of groundwater-based irrigated land. We then articulate our discussion through the lens of legal pluralism, looking at the interplay between state and tribal power, and analyzing the twin strategies of accessing land and water in desert area. We conclude by showing the historical continuity of land tenure relationships and situating our findings in the wider debate on desert land reclamation.

\subsection{Historical context}

The history of land tenure in the Ottoman Empire and during the British Mandate has been the subject of substantial scholarship. We provide here only a summary of the historical background, while the reader is referred to seminal works such as Fischbach, 2000; Mundy and Saumarez Smith, 2007; Owen, 2000, or Bunton, 2007 for further details. Early rules governing the usufruct of lands were a result of the expansion of the Ottoman Empire and 
the conquest of new lands. Local inhabitants of Islamic faith, or converting to it, would pay a tithe called ushuri equivalent to one-tenth of the production of their land, while non-Muslimif allowed to keep their land - would pay a tribute called kharaj. The Sultan could also grant iqtaa land to private individuals such as military officers as rewards for their services (with the obligation to cultivate the land). In all cases, the Sultan or Emir was to remain the ultimate owner of the land (Islamoglu, 2000; Sait and Lim, 2006; Mundy and Saumarez Smith, 2007).

The Land Code issued in 1858, in parallel with the Civil Code (Mejelle), aimed at making a kind of land inventory for taxation purpose and increasing tax revenue, and exercising greater state control over the empire (Carroll, 2011; Islamoglu, 2000). The Code organized a system of taxation that would apply to every piece of land, either privately owned (milk) or part of a domain called miri (land under the custody of the Amiri, or prince), that included all arable fields, pasturing grounds and woodlands. Miri holders would enjoy the use of the land after being registered officially and against payment of a fee (tapu), on condition that it remained cultivated (Fischbach, 2000). Milk land was directly composed of former ushuri and kharaj lands and also included land for dwellings with appurtenant plots not exceeding one dunum. ${ }^{5}$

State ownership extended to two other categories of land, matrūka (such as roads, threshing floors or market places), and mawat ('dead' or wasteland such as mountains and rocky places far from villages). Anyone cultivating such land could "upon payment of a fee, be issued a title deed to the continued usufruct of the land" (or even gratuitously if it was considered a question of need) (Bunton, 2007: 35), the land being then reclassified as miri (Fischbach, 2000: 27). Waqf land was another class of land dedicated to some pious purpose and put under the custody of God, and therefore "protected by the strongest legal and religious sanctions known to Muslim law from seizure by the state or its officers" (Shehadeh, 1982).

Although not mentioned in the Code, the category of state land (amlak al-dawla) appeared during the Ottoman times and differed from miri in that the state did not sell usufructuary rights to it but rented it on a yearly or short-term basis, keeping greater control on this land (Fischbach, 2000: 52). Miri land left uncultivated for three years (and then called mahlul) would revert to the state. Large tribes such as Beni Sakhr and 'Adwan lost part of the land they considered as part of their dira ${ }^{6}$ to the treasury through this mechanism (Fischbach, 2000).

After being entrusted with a mandate over Palestine in 1921, the British confirmed the validity of the Ottoman law but passed several ordinances (Bunton, 2007), such as the Mawat Land Ordinance (1921) that made the reclamation and cultivation of mawat land unlawful (ibid.). The British first conducted a land valuation study, dividing the surveyed area in hawds ('basins' of no less than $250 \mathrm{du}$ ) and ascribing a taxation figure for each of them, based on the estimated productive value of the land (grade). A land settlement program ensued, whereby plots would be ascribed to specific 'owners'. Between 1933 and 1950, altogether 7.77 million du of agricultural land belonging to 412 villages out of a total of 480 for the whole country were settled (Fischbach, 2000: 115 and 158).

\footnotetext{
${ }^{5}$ One Turkish dunam $=919.3024 \mathrm{~m} 2$; the dunum has later been redefined as 0.10 ha, to fit European units.

${ }^{6}$ The tribe's grazing grounds and camping unit (Al Sirhan, 1998).
} 


\section{Chapter 5}

Two important points for our discussion must be noted. First the British land settlement program was limited to the villages of the provinces of Ajlun, Al Balqa, Al-Karak and Ma'an, where agriculture was practiced and where taxes could be levied. Tribes residing in or claiming semi-desert rangelands and desert lands could use them as pastureland, occasional agriculture, or dwellings, and could in theory apply for registration to have these lands under their names. Many tribe members refused to go to such an extent for fear of taxation or conscription, or to manifest their opposition to the state's claims over land (Razzaz, 1992; Madanat, 2010).

Second, the settlement gave rise to the expanding category of 'state land', which included not only the personal properties of the deceased Sultan Abdulhamid II, the waqf lands that were under the control of the Sultan's treasury (Fischbach, 2000: 117), but also all the land considered as mawat, pastures and other collective land coming under the matrüka category, as well as forest land (already under government administration in the late Ottoman period). Altogether roughly 450,000 du were eventually sold by the state through a process called tafwid (delegation); in 1953, the state still possessed 2.64 million du out of the area registered during the settlement (40\% of which were forested) (Fischbach, 2000; Baer, 1957).

After the establishment of the Hashemite Kingdom of Jordan in 1946, the Constitutions of 1951 and 1952 amended but did not repeal the Land Code. Several important laws passed in the 1950s provided further rights to the miri landholder who could now sell, lease, rent or mortgage his plot, transferred all miri land within municipal boundaries to the milk category, and vested all power to administer state properties in the Director of the Department of Land and Survey (DLS) (Shehadeh, 1982). Later, the State land delegation and renting Law No. 53 of 1977 codified the conditions for renting or 'delegating' state land (see below).

\subsection{Land issues in the past three decades}

While all mawat and desert lands, as well as forests, had been shifted by the British under the category of state land, both urban sprawl, in particular to the West and South of Amman, and agricultural expansion in the desert came to challenge state 'ownership'. Urban sprawl was the result of population growth but more importantly of the settlement of Palestinian refugee camps in the late 60s, as well as of the families of migrants established in the Gulf who returned en masse after 1991, with the financial capacity to purchase flats and houses (Razzaz, 1992), and of tax breaks or exemption to housing companies, which all turned the construction sector into a very profitable venture (Madanat, 2010). More recently, in the 2000s, the American invasion of Iraq spurred an influx of Iraqi into Jordan and a dramatic growth in land transactions and values (Figure 5-1), fuelling a real estate frenzy spreading across the Jordanian elite and a bubble which eventually partly burst in 2008 (Madanat, 2010).

Thirst for land, whether for family settlement or speculative purposes, put pressure on 'state land' and on the diverse legal mechanisms whereby state land can be used by or transferred to private individuals: land settlement (taswiye); land 'delegation' (tafwid); Royal gift (makrama malikiya). These mechanisms are briefly described and then illustrated by a number of cases that have made the news in the past three decades. 


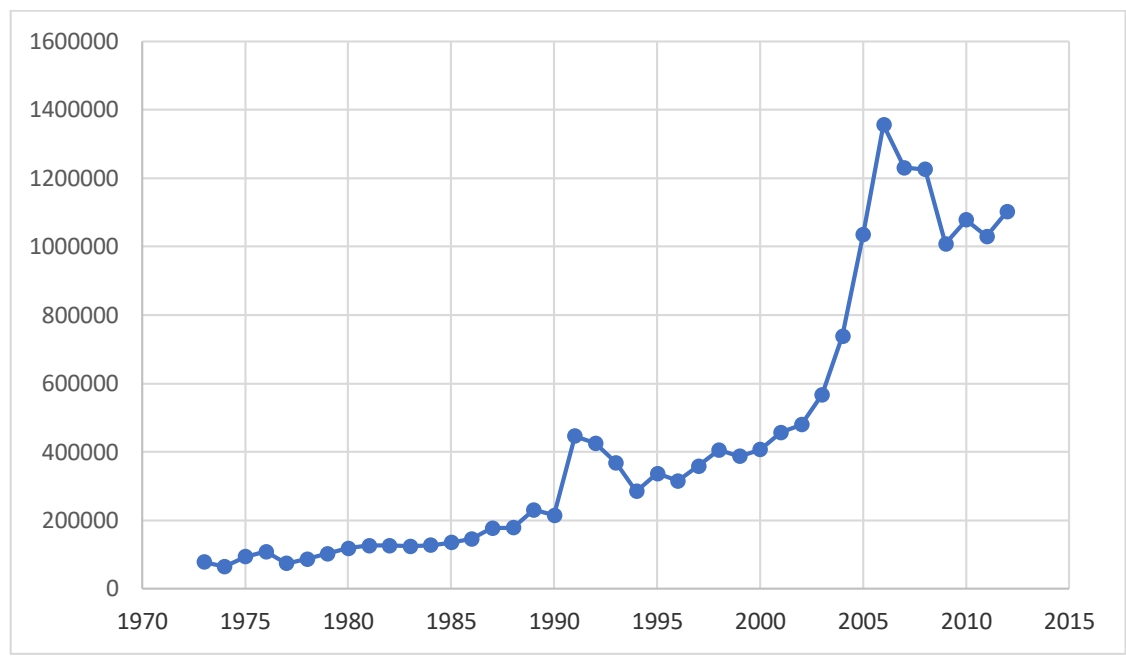

Figure 5-1. Number of transactions in the years 1973-2012 (DLS annual reports; Razzaz, 1992)

\subsubsection{Transfer mechanisms of state land to private use or property}

\subsubsection{Taswiye}

The settlement (taswiye) procedure is drawn from the 1952 Land and Water Settlement Law, and is largely patterned on the land settlement operations carried out by the British between 1930 and 1946. A group of potential owners can request the opening of a taswiye process if they together claim an area of no less than $6,000 \mathrm{du}$. The request is first reviewed by the Governorate and then by DLS, which checks conformity of the claim with the law and forwards it to the Prime Minister for approval. Pending a positive answer, the settlement will be announced in the newspapers and in public places and followed by starting a survey of the area, the attribution of numbers to all plots and hawds ('basins'), and the listing of present persons using/claiming the land in a "field book."

Claims (and counterclaims, if any) are examined, sometimes giving way to cases in a special Land Court, either between claimants or between a claimant and the state, and the settlement officer - just like in British times - is still endowed with a substantial degree of discretionary power to take decisions according to the most convincing evidence. All documents possibly provided by claimants are important, and people diligently keep all kinds of official bills (water, electricity, tax, etc.), fines or documents that prove some occupation of the land. Although not recognized officially, the hijjeh ('proof') is a key document. The hijjeh is signed by an authoritative person of the tribe claiming historical rights to the land in question, and two to three witnesses (who certify that the land belongs to, or was reclaimed by, the person 'selling' the land). The 'buyer' can use this paper to sell his land thereafter, without any protection, of course, from possible bad surprises (e.g., several hijjeh issued by different sheikhs, or even fake ${ }^{7}$ ones).

\footnotetext{
${ }^{7}$ We were shown by one official a hijjeh established in the name of a non-existing person, and corresponding to a plot of land which was found to already belong to someone else.
} 


\section{Chapter 5}

A first 'table of claims' is published in public places, with the names of claimants and corresponding plots, for a period of one month during which people can raise objections. In the absence of contestation, names are moved to the final 'table of rights' and the new 'owners' receive a kushan (private land deed) (Jordan, 1952).

\subsubsection{Tafwid}

The delegation of land (tafwid) is ruled by Law No. 17 of 1974 "State property administration law and its amendments" and Law No. 53 of 1977 "State property delegation and renting law, and its amendments." People, private or public companies can rent state land from the government in order to build, cultivate or make a project on it. Would-be renters should present their project through an application directly to the DLS Director. Before the land may be 'delegated' for agricultural purpose it should be rented (from the state) for a minimum of five years, after which it can be legally registered under the beneficiary's name (who will however not be able to sell the land during a subsequent period of ten years). The maximum area that can be delegated varies according to the location of the land, with up to $500 \mathrm{du}$ in desert (eastern) lands. Tribes and settlers take advantage of this law to first occupy land, reclaim and cultivate it, and then claim it officially.

Two points should be noted here: in practice, farmers seldom go to the DLS with a project and, rather, start cultivation outright, in general drilling an illegal well at the same time, in order to be able to irrigate. They also notify the Ministry of Agriculture, which, through its regional directorate, comes and checks the reality of the farming activity and registers the area and the type of crop, which will be needed to consider the application of the farmer to obtain permits for foreign agricultural laborers. After cultivation is established, they undertake the DLS procedure. As for taswiye, investors generally go through negotiations with tribal leaders and obtain a hijjeh, but they can also ignore their unofficial claim and choose to consider - at their own risk - the land as owned by the state ('only').

\subsubsection{Land dedication}

In other instances, the state can decide to distribute land from the treasury, through a grant from his Majesty the King through the Royal Court (makrama malikiya). Since a ministry or a municipality cannot legally sell or distribute land to private persons, the land is first given to the Royal Court and the King then distributes it. This has frequently been resorted to for distributing housing plots to some categories of civil servants or specific constituencies, for political purposes or otherwise. For example, King Abdallah the second granted plots of land to employees from DLS, the Ministry of Finance, Jordan Audit Bureau, the Royal Court, teachers, past ministers, or judges, as in 2006 when 598 judges benefitted from lands in Amman, Yajouz, Tabarbour and Marka (Al Khatatbeh, 2006). The land is then allocated through a tafwid process.

In the aftermath of the Arab Spring and due to the volatile political situation that prevailed hitherto, land dedication to tribes and poor constituencies has been heavily resorted to, most notably in Ma'an (see later section). Another example is the land dedication process carried out in Wadi Rum in 2013, while another set of 223 land plots was dedicated to the Al Zalabieh Tribe in early 2015 (AlRabeenews, 2015). 


\subsubsection{Zarqa-Ruseifa and the Amman periphery}

The land issues generated by urban expansion are aptly illustrated by the area of ZarqaRuseifa, northeast of Amman. The story started in the late 1960s, with the first hundreds of thousands Palestinian refugees coming to Jordan and settled by the government in this area, as well as in other camps. Faced with the informal settlement of refugees around these camps, members of the Bani Hassan Tribe started dividing the land between themselves and issuing hijjeh to sell plots to Palestinians. The Bani Hassan attempted to regularize their land in the 80s but their request was turned down by the DLS on the ground that they had not claimed the land when settlement was offered in the 1950s, and that, in addition, they had failed to cultivate the land for three consecutive years (Razzaz, 1992).

As settlement on state land expanded, the government responded by establishing in 1980 a Committee for Protecting State Property which was charged "with protecting state owned land and maintaining law and order on those lands" (Razzaz, 1992), while armed forces started to demolish their houses. This resulted in riots and armed opposition from the Bani Hassan (Dayeh and Naganuma, 2009), and eventually in the resignation of Prime Minister Mudar Badran in 1984.

After a long fight with the Bani Hassan tribe in Yajoz/Ruseifa-Zarqa, the state decided to legalize plots occupied by Bani Hassan members and by settlers who had 'bought' the land from them. In 1986, the government started a tafwid procedure between the claimants and the state in order to legalize houses and other constructions which were built on state land. Several calls for settlement were introduced, starting from early 2000 and throughout to 2013. In 2008, a total of 11,000 citizens had taken advantage of these regularizations and paid the required fees, while 40,000 more were still waiting to have their situation regularized (Al Muala, 2008).

The land issue rose again to prominence in the wake of the Arab Spring. In 2011, several demonstrations were held in Jordan to protest about the distribution of land by the government for housing projects for civil servants or to investors, in particular in the North of Amman, where several tribes were claiming ownership. For example, lands had been sold to finance ministry employees for housing purposes in 2004 under a cabinet decision (TJT, 2011), and in 2009, to employees of the Prime Ministry and the Ministry of Finance and its departments (Madanat, 2010). ${ }^{8}$ Through organizing demonstrations and a "Friday to return lands", unemployed youths from tribes such as the Bani Sakher, Zawahreh or Khalayleh blocked the roads and demanded authorization from the government to utilize lands in the area, which they claimed as part of their "right to use tribal wajihat" (TJT, 2012). The Royal Court called leaders of both tribes for a meeting and decided to delegate the land to 70,000 tribe members. When the delegation process started the tribes were shocked to see that $80 \%$ of their land was already owned by a private university and other individuals (Abed, 2015).

\subsubsection{Ma'an Governorate}

The southern Governorate of Ma'an is well known for its restive population and has a record of riots and rebellions (ICG, 2003a). In 1989, the sudden increase in fuel prices prompted

\footnotetext{
${ }^{8}$ www.middle-east-online.com/english/?id=44378
} 


\section{Chapter 5}

Ma'an residents to take to the streets and the military to put the city under siege in order to suppress the insurrection (Bouziane, 2010). Similar clashes were witnessed in August 1996, after an increase in the price of bread, and again in 1998.

Following the unrest associated with the Arab Spring, the regime decided to assuage tribal protests by distributing land from the treasury, through a royal grant in early 2014, with 70,000 du of state land in Wadi Al Ateq granted to Ma'an tribal members in the proportion of one dunum to each person holding a national ID (Al Khatab, 2014). A number of complaints were raised by different Jordanian parties about this distribution of land, some other tribes demanding an equal treatment and to be also granted land. But another problem arose when it turned out that the land earmarked for distribution was located $20 \mathrm{~km}$ away from the city, which was refused by Ma'an tribal leaders (Allofjo, 2014; Al Moghrabi, 2014).

Demonstrations were also started by the Howetat tribe in Ma'an Province, which complained that the land to be distributed to Ma'an's tribes belonged to the Howetat since the establishment of Jordan, and that they had a hijjeh confirming this. The government lately decided to stop the grant procedure and study it again, taking into account these claims and promising to solve the problem by giving the Howetat their tribal land and choosing another land for Ma'an tribes (Al Moghrabi, 2014; Abd Al Hadi, 2014).

\subsubsection{Registering desert land}

The occupation of land also spread into desert areas, where people established cultivation based on groundwater as a means of later claiming ownership (see next section). Several times the DLS tried to address the problem is several ways, lastly in 2000 when it launched a project (named the "Unsurveyed Lands Project") to survey the eastern part of the country with the purpose of registering the lands in the name of both those occupying them and the Treasury. Indeed, despite the remarkable surveying efforts displayed hitherto, only $25 \%$ of the total kingdom area was registered and mapped in the cadastre, with the remaining $75 \%$ still unsurveyed and prone to illegal appropriation. The teams of surveyors divided the area in units of $10 \mathrm{~km} \times 10 \mathrm{~km}$ and altogether 330 land tracts (with a total area of 60,834 km²) were registered as treasury land as a result of the project. In 56 locations which were found to be already in use (totaling $8,498 \mathrm{~km}^{2}$ ), a process of settlement was announced and carried out between 2000 and 2006 (Al Khatatbeh, 2006). According to DLS annual reports, 145 settlement were announced during that period (against 18 for the 2006-2012 period), including land of the Srour tribe in Mafraq (Um Al Jamal), as part of the "project for the survey and settlement of mahlul lands (tribal lands)".

The DLS offered potential owners to pay a minimal fee to get the land legally. However, only a minority of the potential owners were willing to pay, the rest refusing on the basis that they had already either paid for the land or 'owned' it for a long time. The DLS went as far as proposing a fee of only 1 JD per plot for settlers to obtain a private land title (kushan), but this regularization process was discontinued in 2006 by the Prime Minister, as the level of conflict generated by the process became unmanageable (Madanat, 2010). They were resumed in 2011, in the wake of the Arab Spring, when the DLS announced 13 settlement procedures in the whole country (DLS, 2011), but only one settlement had been officially published in 2012 (DLS, 2012). 
In 2012, the Prime Minister asked the DLS and the Ministry of Interior to prepare a detailed map with a delineation of tribal land and boundaries (Al Khatatbeh, 2015). Altogether 4,000 requests from tribes from all over the country were received by the DLS, together with various old documents, from Ottoman, British times or otherwise, purporting to prove previous delegation or ownership. Todate, the DLS is still studying the requests and preparing a map showing tribal lands (Allofjo, 2012), but one Key Informant stressed that this was more of a delaying tactic, since such a map would open the way for unthinkable claims to massive tracts of land.

\subsection{Desert rights: the case of Azraq Basin}

\subsubsection{Setting}

Azraq Basin is a endorheic basin located $120 \mathrm{~km}$ northeast of Amman (Figure 5-2), where surface water and groundwater naturally flow to a central wetland, a Ramsar site of major importance. Because of the shallow nature of groundwater, irrigated agriculture as well as abstraction of water for Amman have developed to the point that water use exceeded the available resource, resulting in a drawdown of the water table by 0.3-0.8 m/yr (Mesnil and Habjoka, 2012). As a result, local springs dried in the early 90s, the wetland being currently only sustained, at $10 \%$ of its original area, by water extracted by wells. The depth of groundwater in the usable aquifer varies from a few meters in the center of Azraq Oasis to $350 \mathrm{~m}$ in Mafraq, in the northern part of the catchment area (Abdalla et al., 1999). According to the Ministry of Agriculture there are about 104,285 du of lands cultivated in Azraq District, the main crops being winter vegetables, bersim, fruit trees, grape and olive trees (MoA, 2010).

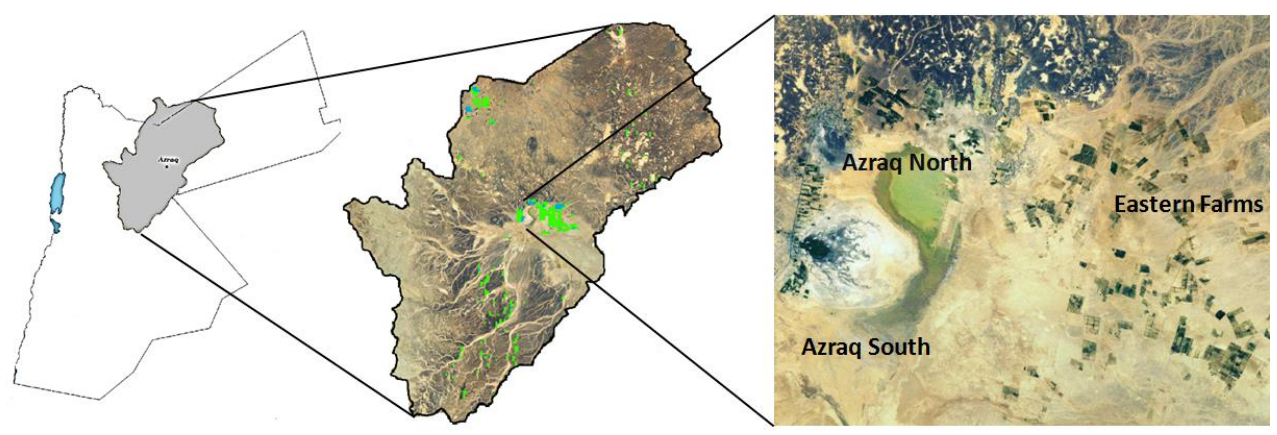

Figure 5-2. Azraq groundwater basin and oasis

The area is home to two major tribes (Beni Sakhr and Al Sarhan, to which can be added the Al Rtmeh clan from the 'Abad Tribe), and also to Chechen and Druze minorities, the former settled by the Ottomans in 1902 as they were fleeing from the Russian army, the latter coming in 1920 from Jabal Al Arab, after confrontation with the French (GIZ, 2010). It is reported that tribes showed a good hospitality to both groups, perhaps on account of the limited numbers of settlers and existing population at the time. Chechen settled in the southwest of the wetland, while Druze stayed in North Azraq.

Most Bedouins dwell outside of municipal boundaries in the eastern part of Azraq, where they claim large tracts of state land. Bedouins are in general involved in extensive agriculture 


\section{Chapter 5}

(olive trees and bersim for their animals), as a means of occupying and claiming the land, and later generating revenue from land trading. According to a DLS officer, Bedouins are "not attached to land, they keep moving, and look down at farmers as if they were slaves". An investor feels that "Bedouins do not like agriculture that much, they prefer to sell land and take money". This image has to be balanced, however, by the fact that tribal members sometimes do indulge in intensive farming (for example in Mafraq), an Al Sirhan sheikh underlining that "a lot of tribe members sell a part of their land in order to succeed in agriculture because they need money to invest".

Most of the farms in Azraq belong to investors, around 90\% of whom reside in Amman or other large cities, or even in foreign countries (Iraq, Kuwait). Many are of Palestinian origin, and frequently have other farms in the Jordan Valley or Mafraq. Among them feature powerful figures such as former ministers, heads of the public security and intelligence apparatus, senators, members of parliament and big investors like owners of shopping malls. They were attracted to Azraq by cheap land prices, compared with other areas in Jordan, and water availability, since the water table is only between $10-20 \mathrm{~m}$ below the surface (compared with over $150 \mathrm{~m}$ in Mafraq)..$^{9}$ Investing in a farm that uses one or more wells is much cheaper than in Mafraq, the reason for which investors in Mafraq look down to Azraq farmers as poor investors, '10 'Sunday farmers', or land speculators.

One Sheikh mentioned that he came to invest in Azraq in the late sixties not only because he used to go there as a child but also because, with the wave of Palestinian refugees after 1967, many people expected that a refugee camp would be established in Azraq (there were, in particular, talks than one camp in Lebanon would be transferred there). After the start of the wars in Iraq and Syria, some people started to invest in the area for the same reason, expecting that the availability of water and the proximity to Saudi Arabia and Syria would designate the area for the establishment of refugee camps (this indeed happened in 2013), and therefore would raise land prices. This illustrates speculative strategies linked to expectation about the changing importance of the area in the future.

\subsubsection{Land conflicts}

Relationships between Chechen, Druze and Bedouins are commonly said to be good, but there is also a clear will not to report or emphasize conflicts. Despite this fact, we heard about instances of conflicts, such as for example a disputed land between Chechens and Bedouins along the road to Amman, and also one instance of death of a Druze at the hand of a Al-Sarhan member in a land-related conflict.

Sheikhs from both Al Sarhan and Bani Sakher tribes reported they had a document from Ottoman times indicating their rights to the land, but this is often a standard claim and could not be verified. It is common among Bedouin Sheikhs to emphasize that "each tribe has its own specific control area. Each tribe knows where its lands are... and people know the pasture used by each tribe, so they avoid using it" (an Al-Sarhan sheikh). Although it is difficult to substantiate these claims, which are contradicted by instances of conflict, we did

\footnotetext{
${ }^{9}$ Wells in Azraq are typically 60-100 $\mathrm{m}$ deep and have discharges from 30 to $120 \mathrm{~m}^{3} / \mathrm{h}$.

${ }^{10}$ According to one of them "small investors will come to Azraq and when he gets money he will move to Mafraq [to invest there].
} 
chance upon an agreement between three tribes shown to us by a sheikh of the Al Sarhan Tribe (Figure 5-3). The document dated 5 January 1934 is signed by a Druze Sheikh named Muhammad Atieh (Abu Sharash), a Chechen leader and Saleh Al Sarhan, in the presence of M. Saleh, member of parliament for Azraq, and defines demarcations between them: "Sarhan tribes' boundaries are located between the old Sarhan's house to the north, to the old Sarhan's graves to the south, and from the old mountain in the east of Qaisie spring to the old castle and palm trees to the west. Any member from any of the three tribes who claims others' land boundaries will have to pay 300 (geneh) and will go to prison for 3 years".

Relationships between investors and Bedouins (or Druze) are in general reported to be good but this partly reflects a clear intent to avoid referring to conflicts in a context where power relations are often lopsided. One Palestinian investor for example, while claiming that he had excellent relations with all Bedouins - and frequently demonstrated that by helping them in different ways such as transportation to the hospital, gift of fruits or other productions admitted that some of them were considering themselves above the law or superior, and liked to display an implicit power of intimidation or subjection. ${ }^{11}$ Another Palestinian investor in Mafraq was forced by his neighbor to deliver water to his fields which, even though he paid for the associated energy costs, is clearly prohibited and punished by law. He felt he had no solution other than complying, for fear of seeing his vehicles or trees damaged. One could be tempted to see a continuity between the khuwwa (protection money) that was historically exacted by tribes on settled farmers (Jaussen, 1948), and the way this is now done through the issuance of hijjehs. ${ }^{12}$

Conflicts within tribes also occur but are not frequently reported. Land demarcation, in the absence of clear mapping or cadastre, gives way to contestation, as tribal members make marks on the soil, or dig trenches by tractor, to indicate the limit of their land, while some of them also build a small house without a roof to strengthen their claim to the land in front of the state patrol. Furr and Al-Serhan (2008) report the case of a bloodshed that occurred in 1996 in the tribe of Al Sarhan, where an elderly man was killed after allegedly trying to extend his land by shifting and digging new landmarks.

\footnotetext{
${ }^{11}$ One anecdote referred to a shopkeeper who sells different types of agricultural products, and who would never dare reminding one Sheikh of his debts, since this would be seen as unacceptably instructing him to pay.

${ }^{12}$ The Beni Sakher were known to extract money from lesser tribes and haj pilgrims (Fischbach, 2000: 15), until they were defeated by the Ottoman army in 1867.
} 


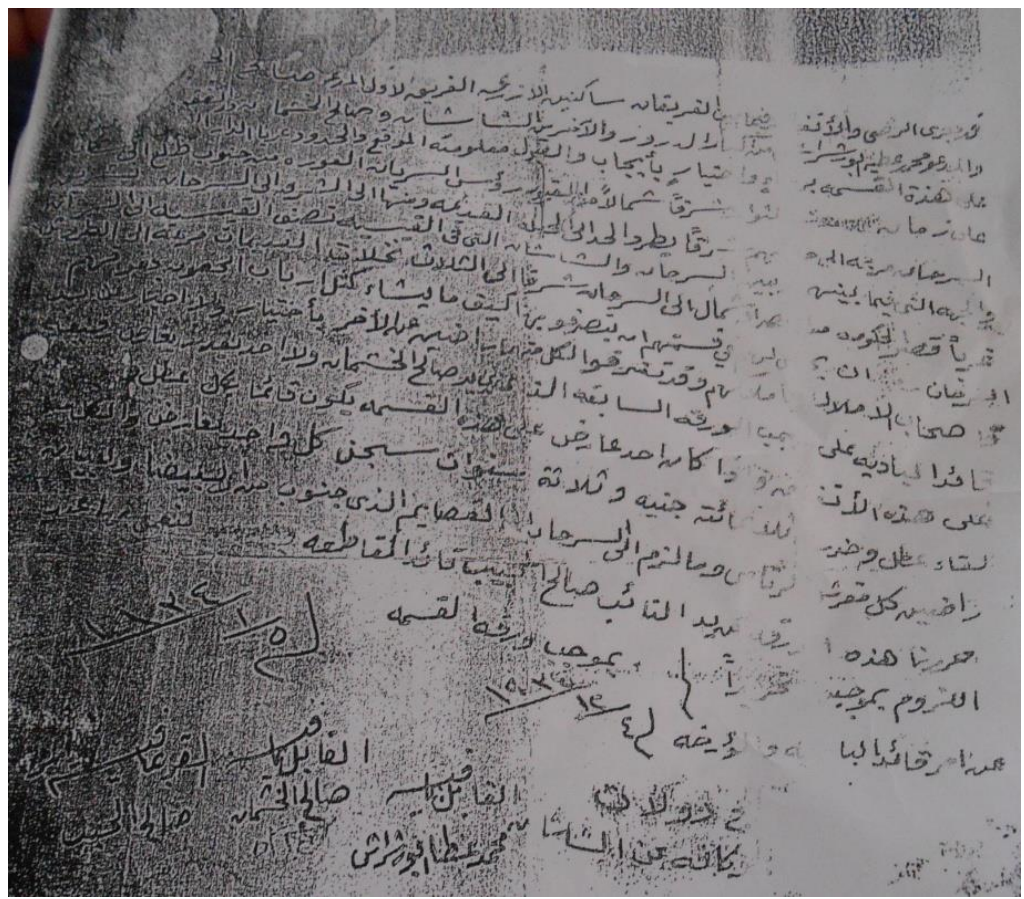

Figure 5-3. Old inter-tribe agreement (1934)

The principal cause for disagreement (and resentment) within tribes is associated with the way tribal land has been partitioned between tribe members. When asked according to what criteria tribal land was divided between its member, one member answered "according to the influence and power", while stressing that his father not only distributed land equally, 400 du to each family, whether sheikh or 'herder', but also to people "outside the tribe". By contrast, an Al Zubi sheikh was reported to have taken all the land for himself. In another case "the sheikh got 400 du while the 'herder' got 4 du". One of the Bani Sakher sheikhs in east Azraq reportedly claimed 6,000 du for himself and distributed the rest between his brothers, sisters and children.

One Sarhan tribe member insisted that "tribal land distribution is not fair. The sheikh got the land from the king and it was written that this land was for the sheikh and his people... When I grew up I went to the DLS to check if there was land for me, I found out that the Sheikh had sold the land to people outside the Al Sarhan family, mainly to people from Syria. I wanted to raise a complaint in the court against the sheikh, based on the king's document. Our sheikh did not give us anything from the land he received". The sheikh had reportedly sold 100,000 du of tribal land to Syrian at the price of $1 J D / d u$ in an area near the Saudi border.

\subsubsection{Land markets and policies in Azraq}

Land policy in Azraq has followed the usual pattern of carrots and sticks, alternating land regularization and coercive measures. The government controlling encroachment on state land through the patrol has tried several times to quell the occupation of state land and to destroy illegal farms. For example, a Chechen farmer reported that he put some empty land 
into cultivation 30 years ago but that the government intervened and destroyed his crops. He later cultivated the plot again and after 10 years of cultivation went to DLS to claim ownership of the land. This coincided with the time when, a few months later, DLS considered his hawd (no. 12) for regularization (taswiye). One Palestinian investor is cultivating illegally a plot that is on state land, expecting the patrol to come anytime to destroy his cultivation, but yet preferring "to deal with that risk since in the meantime [he] can obtain profit rather than stopping cultivation or waiting for a loss if the plot is destroyed". One of the investors interviewed bought the land from a Druze family through hijjeh in 1999 and then regularized the land after 3 years when the DLS opened a settlement procedure. But after registering the land he extended his cultivation illegally. The government spotted his land, recorded his infringement of the law and sent the case to court. It is apparent that whether or not the state intervenes is strongly related to the social power of the owner of the farm, with Bani Sakher sheikh's social power widely reported in different ways by farmers to be "much stronger that the DLS patrol", especially with elements of the Bani Sakher tribes in the parliament and in influent positions in the government.

The way access to land is mediated by social and political power is therefore highly personalized is also well illustrated by the case of two Chechen widows (and sisters) which settled on treasury land not far from Azraq city, and illegally built a house there, claiming 6,000 du of land. This was spotted by the Treasury Land Protection Department and they were asked to leave the land. They refused to do so and went to her Royal Highness Princess Alia bint Al Hussein to ask for her kindness, who reportedly requested the government to officially register a smaller plot of land ( $6 \mathrm{du}$ ) around the house in the name of the two sisters.

It is hard to establish exactly when settlement operations have been carried out in Azraq, over which surface area, and for how many beneficiaries. The first reason is that DLS does not divulge such data, for fear that other tribes in other areas of the country would demand equivalent land allocations. Second, a taswiye process unfolds over several years and farmers remember the year in which they received their property title (kushan) rather than the year or the period of the process itself. Many times, properties are registered but the final delivery of the kushan is put on hold because the property contains a non-registered well, which entails that the processes of registration and officialization of land and water (wells) are intertwined. With this uncertainty in mind, we have nevertheless identified settlement decisions by the DLS in 1972, 1980, 1987, 1994, 1998, 2000, and 2002.

The period of land regularization that opened in Azraq in 2000 was part of the "unsurveyed land project", where 17,839 du from hawd no. 3 and 4 in Azraq South were registered in people's name, while 21,082 du of land were leased by the state to local people for agricultural purposes for a period of five years, after which the lands might be delegated to their users (Al Khatatbeh, 2006). Beneficiaries of land settlement had to pay a minor fee corresponding to $0.016 \%$ of the actual market price.

An influential Chechen resident indicated that a royal grant (makrama malikiya) was announced in 2006, after a visit by the King to Azraq, to dedicate one dunum of land to each (new) family in Azraq, so they could build a house on it. The dedication concerned lands along Azraq main road, near the city, and was mostly targeted at Chechen and Druze; however, Bedouins also largely benefitted from this grant, something that Chechen and 


\section{Chapter 5}

Druze resented because they consider themselves as the first people to have settled in what is now Azraq City, unlike the Bedouins who, they stress, "keep traveling between Azraq and Saudi Arabia or Iraq". A total of 70,000 du were eventually distributed in 2009, at a nominal price of $30 \mathrm{JD} / \mathrm{du}$ ( $8 \%$ of the estimated land value of $350 \mathrm{JD} / \mathrm{du}$, price for bare soil).

Problems linked to the partial informality of the land market and to the issuance of hijjeh are illustrated by a Palestinian in the North Azraq area, who bought his land from a Bedouin sheikh in 1998. After one year of buying the land it appeared that there were several Bedouins with hijjeh for the same land. He was eventually forced to buy the land again from them. This clearly shows that the conditions of buying land, and the risks attached to them, reflect the perceived balance of power between the buyer and the seller, the latter sometimes not hesitating in using intimidation to extract more money from a buyer believed to be in a weaker position. Another story involves an investor who tried to cultivate land claimed by local Bedouins without paying for a hijjeh. This resulted in intimidation and conflict, and eventually the municipality's intervention and the removal of his trees. The precariousness of the hijjeh is also illustrated by the taswiye in 2007, when some Bedouins pressured hijjeh holders to sell their hijjeh back to them at the same price they had bought it, so that they could regularize their land and benefit from its massive increase in value...

Out of the 54 farmers interviewed in Azraq, 41 claimed to have official private land deeds (kushan), while out of the 13 remaining cultivating land illegally, five reported to have hijjeh, the remaining eight cultivating state land without permission. Because of the sensitivity of the issue it can be hypothesized that some farmers cultivating land illegally reported to have legal documents.

\subsubsection{Land prices}

The evolution of the price of land in Azraq reflects the evolution of the land market in Jordan in general, and local characteristics in particular. Figure 5-4 shows the differences in land price according to the area and year in Azraq Region, based on transactions recorded during field work. Note that prices have now notably increased, with current land prices in Azraq Chechen at around 4500-5000 JD/du.

It is important to note that the prices indicated in the graph originate from direct interviews with farmers in Azraq, and reflect the price that was paid by them when they got the land. There are a number of farms 'owned' and cultivated illegally where, as a result, the owner did not pay anything for the land. It is however difficult to compare prices because it is influenced by whether the land had an official state title deed (kushan) or a vernacular contract (hijjeh), whether it already included a well or not, whether this well was legal or not (more on this later), what was its discharge and the quality of water, and whether electricity from the grid was available. The data as shown on the chart referred to legal land (with some additional unconnected isolated points corresponding to hijjeh transactions). 


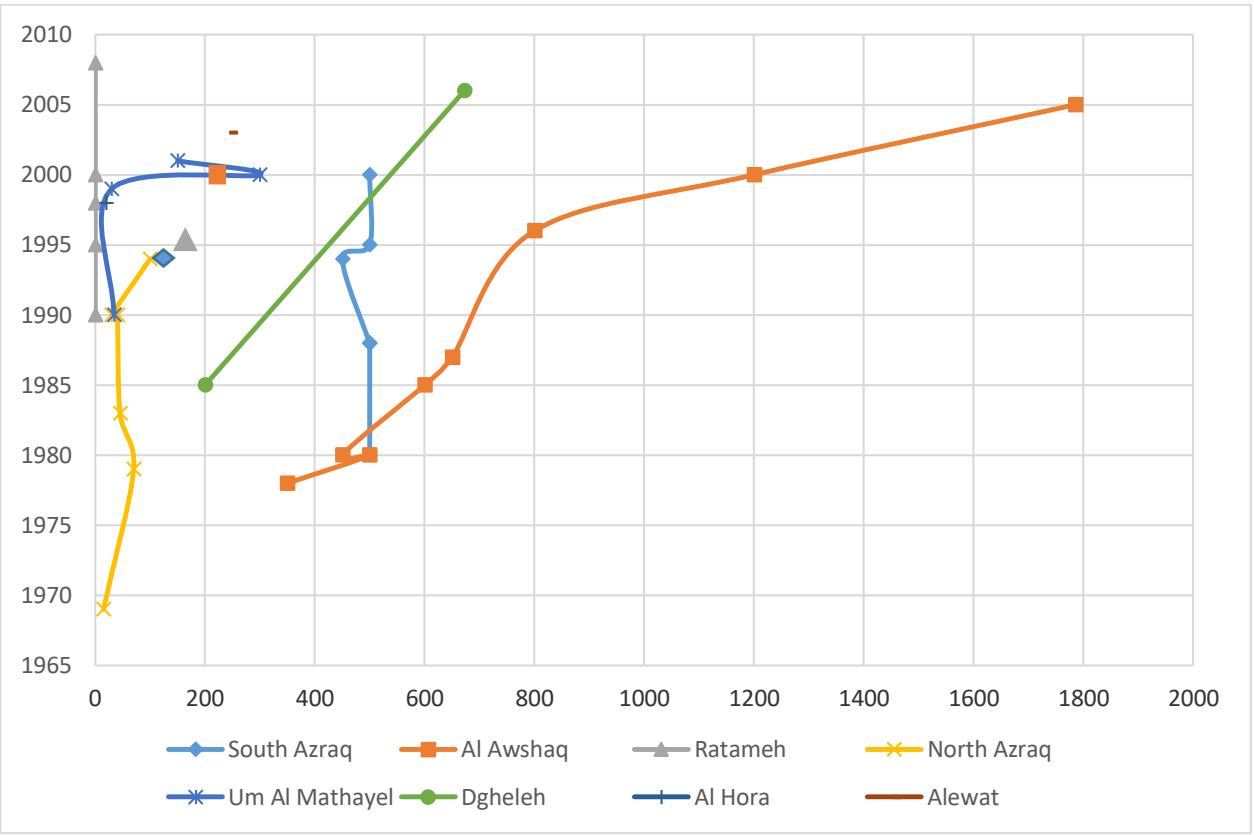

Figure 5-4. Reported prices (JD) of land transaction according to place and time

North Azraq farmers are mainly Druze, while South Azraq is home to the Chechen. Land prices have been quite low and stable, on account of the fact that their lands were regularized at their request by DLS, against the payment of $0.016 \%$ of the actual land value, and that the farms are small in size, typically $20 \mathrm{du}$, which make them unattractive to investors. In addition, the situation in South Azraq has notably deteriorated due to the over abstraction and the increase in the salinity of groundwater, which explains why land prices are much lower than in North Azraq. Land transactions are limited in number and prices are stable.

In Ratameh, located to the east, and Al Awshaq to the northeast, conditions are favorable for investment. Vast swathes of land of good quality are available for large-scale farming, water is less saline compared to South Azraq, and landownership has already been regularized by DLS, allowing investors to buy land with a kushan and avoid the uncertainty inherent in hijjeh; some investors also rent the land directly from the government for agricultural purposes. Since the land is registered it can benefit from municipal services (electricity, piped water,...). It is clear from the graph that land prices in both areas are the highest, compared to other regions in Azraq. The land market is very active in both areas, with most recent prices ranging between 2,000 and 4,000 JD/du, while some investors recall that in the 70 s land in this area could be obtained for $1 \mathrm{JD} / \mathrm{du}$...

In Mafraq, one dunum of land which was sold at 30 JD in 1995 now reaches 1,000 JD. One landowner recalled that his father was a land trader and had bought a plot of land at the time at 20,000 du. It seems that the land was divided up among the big families and the sheikh, then parceled it out. An influential Srour Sheikh, who belonged to a Syrian tribe, was given land by the late King Hussein in 1964. As a member of parliament with good relations with 


\section{Chapter 5}

the King, he obtained Jordanian Nationality for 5000 of his people as well as 200,000 du in Mafraq area to be distributed among them (despite the opposition of the Bani Hassan tribe).

Cultivation has also expanded eastward, to areas known as Al Mathayel, Dghela or Hora. Eastern farmlands are normally state land occupied - legally or not - by Bedouins (notably from the Khuraysha Clan), who claim it as their tribal land, and investors, who have either bought land through hijjeh at their own risk (with prices around or under $500 \mathrm{JD} / \mathrm{du}$ ). Roads are not paved, and there is no electricity and other services. Energy is sometimes sourced from solar panels.

It is also interesting to note a trend towards renting land, often on a yearly basis. This reduces or even cancels the risk for the person willing to invest in cultivation, whether the land is officially registered on not. This is also a way for Bedouins who have to keep large plots of land under cultivation to do away with the burden of cultivating them, while ensuring a steady revenue and waiting for future taswiye operations. A well with attendant irrigated fields between 200 and $500 \mathrm{du}$ is rented at 20,000 - 30,000 JD per year (10,000-12,000 $J \mathrm{D} / 100 \mathrm{du}$, that is, $1 / 20^{\text {th }}$ of the price of land, in order of magnitude).

\subsection{Discussion}

\subsubsection{Legal and state administration}

On the face of it, land administration in Jordan is highly centralized and organized along western bases, following the model of land management established by the British. And indeed, the legal land system has delivered substantial benefits to the country, reducing conflicts and investment risk, stabilizing state-citizen relationships, and ensuring a relative degree of professionalism, equity and openness, at least with regard to the $25 \%$ of the land under private tenure. The DLS generates a substantial income and has computerized all transactions and cadastral maps with plot-level information (Madanat, 2010).

Although several problems are reported (ranging from mistakes with names, the confidential nature of the information, or instances of corruption), DLS'S administration compares very favorably, for example, with the "disastrous management of public land" in Egypt, as bleakly described by Sims (2015). Dysfunctional property titling, registration, and transfer systems are prevalent and only 15\% of private land parcels are registered; land is not taxed, and no maps are available (ibid.). Unlike in Jordan, there are 11 ministries and 13 government authorities or holding companies with stakes in public land. Since 2007 numerous land scams involving officials and influential people have been unearthed and publicized. According to Sims (2015), the mess is not cleaned for a purpose - "to keep the machine producing 'rents' and windfall profits for vested interests and space for pervasive corruption".

While in countries like Sudan (Gertel et al., 2014), Egypt (Sims, 2015) or Morocco (Mahdi, 2014) the state has mediated the commodification and transfer of 'state land' to private hands (national or foreign developers or companies), often at give-away prices, Jordan has favored local and smaller investors (with the exception of the land leased to three large companies in Disi, whose contracts have now been discontinued). This may be partly due to much scarcer land (and water) resources and a more professional land administration, but also to the heavier weight of tribal politics (see below), and a fairer regime of land distribution constitutive of a relation of trust between citizens and the state (Fischbach 2000), making looting and corruption at the scale witnessed in Egypt more difficult. It 
remains, however, that accessing state land is a key avenue of capital accumulation and that, as such, the politics of land allocation are deeply enmeshed in wider national politics and games of influence and power.

\subsubsection{Legal pluralism and the multiplicity of claims}

While the Jordanian (formal) land system is centralized, it is apparent that Jordan is a classic case of legal pluralism, whereby several registers of legitimacy (Islamic, tribal, official, international...) are simultaneously mobilized and resorted to when dealing with land issues. ${ }^{13}$ Antagonistic references and interests are also visible in the contradictions between different sectoral policies (see $\S 5.3$ ). A prime example of contradiction between practices and the law is the fact that although the exploitation of treasury land is prohibited by law (Madanat, 2010), the practice of exploiting treasury land for agriculture with the hope of later regularizing it with the DLS (through a tafwid or taswiye campaign) is a key strategy of both agricultural expansion and access to land.

The rangelands and desert lands, formally under ownership of the treasury, stand at the confluence of several claims: some investors consider their 'right' to revitalize/reclaim desert land, as legitimized by the Coranic principle ${ }^{14}$ of ihya and made possible by the 1977 Law on tafwid, while local tribes consider them as part of their community dira or wajiha and dismiss state control over them. As we have seen in the preceding section, these claims are also very much about securing a stake in the wealth-generating land market. In the badia, the state is seen as an external actor, "state-legislated tenure [as] usurping customary law" (Patrick, 2002), and legitimacy of claims to land based on agreements between tribes and on arrangements within each of them. While the government considers most of the badia to be state land "the Bedouins consider themselves the real owners of these areas" (Al-Sirhan, 1998). As stressed by Sait and Tempra (2015), "the modernisation of land tenure has not erased the community and Islamic tenures, at least at the unofficial level". Others appeal to international laws, such as the ILO Convention on Indigenous and Tribal Peoples of 1957, which stipulates that they "have the right to live according to their customs...and have the right to own and exploit all the land they were living in at the time of the demarcation of frontiers and establishment of the state", or Article 14 of the International Convention No. 169 of 1989 on the Protection of Tribal Peoples which "provides for the recognition of the rights of indigenous peoples and tribal ownership and possession of the land which they traditionally occupy" (Abed, 2015).

The status of the hijjeh provides a telling example of how the boundaries of legitimacy are blurred. At the time of tafwid or taswiye, hijjehs are considered in settlement and disputes, although their theoretical/legal validity is nil in the eyes of the State. The extent to which the state is ready to accept the legitimacy of a hijjeh is variable, thus reflecting a typical situation of legal pluralism. Wherever political considerations dictate a privatization of state land in areas with few competing claims or expected future use by the state, hijjehs will be

\footnotetext{
${ }^{13}$ Legal pluralism is taken here as "the presence in a social field of more than one legal order" (Griffiths, 1986: 1), adding, with Dupret (2007) that law (or the fragmented spectrum of law) is "what people consider as law" and what they make of it and how.

${ }^{14}$ Like Casciarri (2015) in Sudan, references to Shariaa or Islamic principles did not feature prominently during our interviews.
} 


\section{Chapter 5}

considered as a central element of land attribution. Conversely, typically in the periphery of Amman, where land prices have now skyrocketed, and where until the 1970s the Bani Hassan Tribe would commonly claim and sometimes register this good and fertile land (Razzaz, 1992), the government stands more firmly by its claim to state land because of its growing awareness of its future needs to access land (e.g. for the construction of universities, military or refugee camps or airports). But this is also dependent on the wider political balance (see next section), as illustrated by a state policy that follows a typical fluctuating pattern, alternating between stick and carrots, legalization and destruction. Property rights on land can be conceived of as 'bundles of rights or claims', referring to competing claims or entitlements, that are continually negotiated among groups and individuals (Islamoglu, 2000).

The hijjeh itself can be endowed with different degrees of symbolic value. Some try to enhance the symbolic value of the hijjeh they deliver by using an official letterhead (Razzaz, 1992), while we saw one hijjeh signed by a Katib el Adl, ${ }^{15}$ and bearing several official stamps! Some hijjeh are signed by minor sheikhs, while others can be signed by the paramount sheikh of the tribe, in which case its value will be higher because of the lowest (or nil) risk to see a respected sheikh failing to honor his word or engaging in malpractices. The identity and reputation of the witnesses also matter. Patrick (2002) stresses the importance of the moral aspects of the economy, particularly in tribal areas "where reputation is a key element in developing and maintaining social capital".

Arbitrating between different claims and sources of legitimacy is a highly political game. One lawyer interviewed by Ainnews (2011) called for "creative solution" (hal mubtakar) to get out of these claims. A Key Informant at the DLS recognized that in practice there was a need "to balance between official rights and traditional rights".

\subsubsection{The state and tribal power}

The tribal politics of Jordan, and their constitutive role in state-building have been the subject of much scholarship (Kark and Frantzman, 2012; Alon, 2007; Massad, 2001). We focus here on how the power to access land, or to control the access to it, has played and is still playing a paramount role in maintaining the internal political balance of the country, and in shaping relationships between the state and its citizens, following Fischbach's demonstration (2000), that "In a predominantly agricultural society as Jordan was during the period under study, land and the control of its fruits are powerful factors in determining the socio-economic and political contours of state and society. To no small degree have social forces in modern Jordan been linked to land and land tenure".

The Jordanian regime, since the time of King Abdullah I and the crucial necessity he was in after being placed on the throne of a 'foreign' territory (Patrick, 2002) - to win the support of local tribes to the new Hashemite power, has been built upon a give-and-take relationship with local tribes. This included the enrolment of Bedouins in military units and the state administration, the co-optation of tribal leaders as members of the cabinet, the distribution of tax relief and land grants. Access to land has long featured highly in state-tribes relationships. The tribal Council formed by King Hussein bin Talal in 1970 (but discontinued in

\footnotetext{
${ }^{15}$ Katib El Adl is a person endowed by the government with the power to approve legal transactions and procedures, like wakalat, ratification, verification and translation of documents.
} 
1976) had among its four roles "to delegate (tafwid) the lands of the government to needy tribal people" (Dayeh and Naganuma, 2009). The sensitivity surrounding land issues can be sensed from several confrontational events in the past three decades, as described earlier.

Land-related wealth is increasingly intertwined with politics. New money made on the sale of tribal tracts around the Queen Alia airport enriched the Al-Qaisi and Derabani tribes and, as a result, representatives of these tribes were able to run a highly organized and expensive campaign, and to beat eight Al-Abbadi tribal candidates in the 2010 Parliamentary elections (Weir, 2013). Participating in parliamentary elections and accessing positions of power are essential to "maintaining wasta, or individuals who provide informal goods and services in office" (Strakes, 2011), and having kin members in official state positions ensures the allocation of resources according to their interest (Bouziane, 2010). Political crises or tribal uprisings are invariably soothed away by changing the cabinet and appointing tribal leaders, or opening employment opportunities to youth (Weir, 2013).

The power to allocate state land can also become a critical weakness. In 2011, for example, 36 tribal leaders sent a letter to the king, calling on him "to return to the treasury land and farms given to the [queen's Rania] Yasin family. The land belongs to the Jordanian people" (Zecchini, 2011), an accusation condemned in vehement terms by the Royal Court (Ma'an News, 2011). Irrespective of whether it is founded, the accusation - a rare instance of criticism of the regime directed by the tribal leadership supposed to be loyal to the King illustrates how the wealth associated with the distribution of state land and the sensitivity of the tribes to losing the (partial) control they have on this rent can both strengthen and destabilize the regime, just like the events that occurred with the Bani Hassan Tribe in 1983. An extremely telling and significant manifestation of this state of affairs is, maybe, the fact that the legal contradiction between the 1977 Law allowing wada yadd and the prohibition to occupy state land is routinely swept under the carpet and goes largely unquestioned.

Gerber (1986) and Fischbach (2000) have posited a link between the stability of Jordan, a small and vulnerable country lacking natural resources, and the regime of land distribution that has both established a relation of trust between citizens and the state (which allocated and registered land with neutrality and equity) and dramatically normalized ownership and reduced conflicts. The fact that Jordan largely escaped the political upheavals and agrarian crises/reforms that raged throughout the Middle East from the 1920s to the 1950s is seen by Fischbach (2000) as somehow related to its peculiar land regime, a statement that might be extended now to the crisis following the 'Arab Spring' and the continued use of land for smoothening political relations. More generally, as emphasized by Islamoglu (2000), "state practices are power fields in which both state and social actors confront each other, and negotiate the terms of domination and subjugation which this kind of property implied".

\subsubsection{Accessing land, labor and water}

The wealth-generating land market is at the core of the interface between tribes, which claim the land, and the government, which has the power to dictate its relative value not only through its decisions to distribute land by the different means at its disposal, but also through the degree of law enforcement it chooses to exert on a particular individual. In Azraq, mediating access to land is clearly the first 'resource' of members of local tribes. When we asked one of the interviewees where one could meet some land middleman (simsar), he 


\section{Chapter 5}

said that "any person you meet along the road is a land simsar" and will be able to take you to would-be 'sellers'.

But gaining access to land, with the promise that it will one day be regularized and reach a very high value, is associated with transactions in the labor sector. People with registered agricultural land in the Ministry of Agriculture have the right to ask for migrant labor permits (most of the times from Egypt), on the basis of one per $10 \mathrm{du}$, and even $5 \mathrm{du}$, if one cultivates vegetables. Someone with $200 \mathrm{du}$ irrigated has the right, theoretically, to 20 workers, although he might only need two or three in practice. This surplus labor can be transferred to the construction sector, for which middlemen will pay between 300 and 800 JD to the farmer for ceding 'his' workers (the monthly salary of a worker is 300-350 JD in Azraq, but 750 in the construction sector in Amman). Having a farm also allows one to buy pickups or four-wheel vehicles at a discounted tax.

But more crucially, the agricultural exploitation of the piece of land in desert conditions requires water, that is, a well! While the Ministry of Agriculture has in general been sympathetic to the idea of expanding cultivation, turning a deaf ear to expressed concerns about the sustainability of groundwater-based agriculture, the Ministry of Water Resources and Irrigation has been at grips with the problem for more than 25 years (Venot and Molle, 2008). ${ }^{16}$

From a first ban on the drilling of wells for agricultural purposes in 1992, through the 2002 Bylaw and its policy tools (registering of all wells, metering, free quota and block-pricing of water, etc.), to the 2007 bylaw which indicated that non-licensed agricultural wells drilled after the first of July 2005 would have to be backfilled, and a 2013 decision to backfill wells not legalized by the end of the year, mounting regulatory pressure on groundwater is starting to constrain land acquisition and expansion of agriculture. Farmers are caught up in a contradictory mechanism where no well can be regularized if drilled after 2005 and if the farmer does not have a kushan. At the same time, he needs to have water (a well) to be able to reclaim a piece of land before hoping to see it one day regularized. But all this is dependent not only on whether land will eventually be distributed for political reasons but also on exploiting several loopholes in state regulations and enforcement.

The enforcement of stricter regulation has been weakened by unsustained political will, and corruption, reported at several levels, on both the agricultural and water sides. For example, 'friendly' meter readings (many meters are, in addition, tampered with), illegal drilling, replacement wells (with old wells not backfilled as they should be), etc., illustrate various law enforcement problems, while the 'laborer market' also gives way to bribes and faulty reporting of cultivated areas. Other factors include the insufficient means and staffing, and lack of incentives of the state administration, and the raw power of tribal members. As illustrated by one interviewee's comment on a Bedouin farmer: "it is a tribe and the tribe has power; the small government employee cannot say no to the big tribe".

\subsection{Conclusion}

In most of the Arab world accessing land has always been at the core of capital accumulation and Jordan is no exception. Urban sprawl away from core historical settlements into desert

\footnotetext{
${ }^{16}$ We address the issue of groundwater use regulation in a forthcoming companion paper.
} 
land and the opportunities for high returns on investment in groundwater-based agriculture have fuelled a demand for initially little-valued and non-registered arid land; and have concomitantly resulted in overexploitation of groundwater resources.

While earlier studies on land tenure in Jordan have focused on provinces settled during the British Mandate or in the 50s, and on Amman peri-urban areas, this paper has attempted to shed light on the current dynamics of land settlement, distribution and occupation in the Azraq Basin. At the core of ongoing dynamics are the conflicting claims of the state (which, by law, claim ownership of all non-registered and/or desert lands) and the tribes (which draw on several levels of traditional legitimacy to substantiate their claims). That the stakes are high can be inferred from the fact that unregistered land represented 75\% of Jordan's territory in 2000 , with the government endeavoring to strike a balance between sticking to pure legalism and turning a deaf ear to tribal claims on the one hand, and giving in to pressure, with the unthinkable prospect of having to parcel out to private individuals three quarters of the country, on the other. On balance, while in many other countries the transfer or lease of 'state land' to developers and companies have been described as displacement and a new frontier of capitalist expansion, Jordan has developed a fairer land regime favoring Bedouins, small to medium-scale agricultural investors, rather than -despite some rich or influential urbanite investing in Sunday-farming or land speculation- large-scale developers.

So far the state's land policy has fluctuated between 'carrots' (distributing state land by tafwid or taswiye) and 'sticks' (destroying illegal houses, plantations or wells), in a 'tango' that largely reflects the shifting political bargaining power of tribes in their support to the King, who in turn, has tried to sustain what is generally seen as a successful "balancing act" between tribes (Alon, 2007). But land distribution or regularization by the King and/or DLS in a particular area, tends to generate claims from other tribes, which explains the high sensitivity of this give-and-take strategy (and also why DLS is loathed to communicate on its operation in order to avoid fostering more claims).

Tribes are keen to constantly refer to 'traditional rights to their wajihat' and to seize political 'windows of opportunities', such as the 2011 'Arab Spring', to voice their discontent and transform political threats into land and other political rewards (such as positions in the Cabinet). In a typical case of legal pluralism, non-state conceptions of landownership are able to exist and challenge state concepts, depending on the shifting and negotiated social power that can be mustered behind them.

Investors find themselves caught up in that game. They often have to cope with diverse degrees of illegality (regarding both land and water) and intimidation (sometimes bordering on extortion) from tribal members. They can hardly afford to fall out with local Bedouins, unless they are endowed with, or backed by, very high political power. They are moved not only by possible high rewards of intensive irrigation in the deserts, but also by speculative motives and expectations of ever skyrocketing land prices, and associated benefits such as those coming from 'trading' foreign laborers. But this wealth-accumulating 'game' is, eventually, threatened by the sustainability of the water resource base. The more stringent regulations being enforced in the past months might be a game-changer and herald changes which, however, can be overturned at any moment by the political volatility that characterizes the region 



\section{CHAPTER SIX}

\section{Controlling Groundwater over Abstraction: State Policies vs. Local Practices in Jordan Highlands}

Al Naber, M. and Molle, F. 2017. Controlling groundwater over abstraction: state policies vs. local practices in Jordan highlands. Water Policy, 19; 692-708. 



\title{
6 Chapter Six: Controlling Groundwater over Abstraction: State Policies vs. Local Practices in Jordan Highlands
}

\begin{abstract}
The control of groundwater over abstraction is a vexing problem worldwide. Jordan is one of the countries facing severe water scarcity which has implemented a wide range of measures and policies in the past 20 years. While the gap between formal legal and policy frameworks, and local practices on the ground is widely acknowledged, few studies investigate how local users react to state regulations and document their tactics to circumvent them. This paper examines the major tools implemented by the Jordanian government to control well expansion and water abstraction and how farmers in the Azraq basin have responded to these measures. It then documents how, in response, the Ministry of Water and Irrigation has recently enacted a series of creative counter-measures, both direct and indirect, in an attempt to toughen law enforcement and raise pressure over groundwater users. The lessons learned are highly relevant for countries with similar situations, both in the region and elsewhere.
\end{abstract}

Keywords: Azraq; Groundwater management, Jordan; Over abstraction; Water governance; Water policy

\subsection{Introduction}

The use of groundwater resources has long been overshadowed by the more prominent and visible use of surface water; but as the exploitation of surface water reached (or exceeded) its limits in many river basins, groundwater has gradually taken center stage and now makes up $26 \%$ of total withdrawals at the global level (Margat and van der Gun, 2013). The continued expansion of irrigation worldwide in the past 30 years has largely been fuelled by increasingly resorting to groundwater (FAO, 2015), but the annual contribution of nonrenewable groundwater abstraction to irrigation globally has tripled from 75 to $234 \mathrm{Bm}^{3}$ over the 1960-2000 period (Wada et al., 2012). This worrying situation, where half of groundwater-based agriculture is unsustainable, is nowhere more explicit than in North Africa and the Middle East, where unsustainable groundwater development for irrigation is taking place in arid or desert land (UNDP, 2013a; FAO, 2015; Famiglietti, 2014; Voss et al., 2013).

Although a lot of research has been conducted on physical aspects, the question of how groundwater is and should be governed by societies remains largely a moot issue, bedeviled by a baffling diversity of situations (Mukherji and Shah, 2005; Burke and Moench, 2000) and the thorny issue of common property resource management (Ostrom, 1990). Following standard views on IWRM and governance (Rogers and Hall, 2003), emphasis is often put on the structure and roles of state administrations, as well as on the legal and policy 'tools' they deploy, beside a conventional call for participation. The overemphasis on law and regulations, fuelled by donor-supported policy reforms, has led to a situation where most countries 'have state-of-the-art policies and regulations, but the problem is enforcement and implementation', as this ubiquitous statement goes. Little attention has been devoted to documenting the reasons for such failure and how local actors effectively evade or circumvent the law. 


\section{Chapter 6}

Jordan is a prime example of a country critically dependant on groundwater that has enacted and tested a large range of policies. It is ranked as the world's second poorest country in terms of per capita water availability, with a yearly water abstraction that fluctuated between 800-900 million $\mathrm{m}^{3}\left(\mathrm{Mm}^{3}\right)$ during the past 15 years, and an average available resource of 602 $\mathrm{Mm}^{3}$ (Humpal et al., 2012; MWI, 2013b), the shortfall coming from groundwater depletion. The pressure on water resources is increasing under several external and internal factors, such as the huge increase in population generated by successive waves of refugees in the country's history, and what economists consider to be a sectoral misallocation of its limited available water resources. The percentage of supply going to agriculture in Jordan averages $53 \%$, followed by domestic (42\%) and industrial uses (5\%) (MWI, 2013b), despite the fact that agriculture only contributes to $3 \%$ of the Jordanian GDP and employs $2.6 \%$ of the Jordanian labor force (DoS, 2014).

Jordan draws $60 \%$ of its supply from groundwater, while the remaining comes mainly from the Yarmouk River, with some contribution from the Jordan River and side wadis along the Jordan Valley (Humpal et al., 2012). Reuse of treated wastewater now amounts to 123 $\mathrm{Mm}^{3} /$ year. The municipal sector stands out as the first user of groundwater (48\%), followed by agriculture (46\%) and industry (6\%) (DoS, 2014), with a total abstraction of $540 \mathrm{Mm}^{3}$ (MWI, 2013a). This foreshadows the competition between cities and farmers for precious groundwater resources, and the political costs of favoring the latter over the former. Amman-Zarqa and Azraq basins make up $42 \%$ of the total renewable groundwater resource and are the most over-abstracted aquifers nationwide, with abstraction estimated at $176 \%$ and $215 \%$ of the safe yield (MWI, 2009).

Groundwater-based agriculture started in the highlands in the early 1960s (Demilcamps, 2010). With the dramatic expansion of irrigation and the growing abstraction by cities, Jordan's groundwater resources started to decline and to deteriorate in terms of quality. With average drops in water tables around $1 \mathrm{~m} / \mathrm{yr}$ (Goode, 2012), the unsustainable nature of the groundwater economy became apparent and triggered a series of institutional and legal changes, starting in 1988 and including the 1998 water policy, which established the priority of domestic water over other uses, leaving agriculture as the main sector to be impacted by reallocation.

This paper starts by briefly describing the chronology of groundwater policies in Jordan and then moves to documenting and analyzing their application on the ground, focusing on the aquifer of Azraq basin (with the two distinct areas of Azraq proper and Mafraq). It illustrates how water users have responded and adjusted to the successive measures taken by the government, but also to changes in their wider economic and political environment; and how, in response, the Jordanian government has recently taken further measures and toughened law enforcement.

Although there are numerous reports on, and studies of, formal groundwater regulations and policies, it is much less common to see studies on farmer/users' local practices and responses to policies on the ground (exceptions include, for example, recent works by Reis (2015) on Mexico, or Aarnoudse et al. (2012) on China). We believe however that careful documentation of local practices is key to understanding how measures can be designed more efficiently and farmers behaviors influenced towards a shared goal of sustainability. Jordan's experience in groundwater management is extremely compelling due to its 
exceptional situation of limited resources and the broad range of policies that have already been implemented and tested. Lessons that can be drawn from Jordan's experience for other countries, most particularly from the Middle-East and Northern-Africa, may prove to be extremely valuable, at a time when the government is showing unprecedented resolve to 'tighten the knot' on users through various creative measures.

\subsection{Key steps of groundwater policy in Jordan}

The modern management of water in Jordan started in 1952 with the Land and Water Law, which already considered allocating water through water entitlements, followed by the Groundwater Monitoring Bylaw No. 14 (1961) that focused on the drilling of wells and the licensing of drilling activities through permits granted by the National Authority for Natural Resources that was established in 1965. Groundwater exploitation for irrigated agriculture was encouraged by the government in the early 1970s because it held the promise to provide a reliable source of income, improve social welfare and stability in rural areas, and help settle Bedouins (UNDP, 2013b).

Well licenses and soft loans for drilling private wells have been granted to users by the state. The licenses indicated in general a maximum annual volume of 50,000, 75,000 or 100,000 $\mathrm{m}^{3}$. These volumes were, however, not respected due to weak to non-existent law enforcement and monitoring of groundwater, and to the lack of metering system (Chebaane et al., 2004). Consequently, the highlands became one of the most important agricultural regions in Jordan, with olives, grape, vegetable and fruit trees (MoA, 2010).

The management of groundwater resources remained with the National Authority for Natural Resources until 1984, when it was handed over to the Water Authority of Jordan (WAJ), and to the Ministry of Water and Irrigation (MWI), later established by the Water Authority Law No 18 of 1988.

\subsubsection{The Water Authority Law No 18 of 1988}

Law No 18 defined the distribution of roles and decision-making power among state administrations and established the WAJ, which was, among other things, to

- survey and conserve all water resources and set priorities for their utilization;

- regulate the drilling of public and private wells, and

- explore water sources through exploratory wells; issue licenses for drilling rigs and drillers.

This law clarifies the fact that all existing water sources, whether surface or groundwater, within the borders of the Kingdom are considered as state property and may only be used or transferred in accordance with the provisions of state laws. Law no 18 was the first piece of legislation to introduce fines and prison penalties on illegal well drilling, or when the conditions stipulated in the permits are not respected.

\subsubsection{The Groundwater Bylaw of 2002}

Most of the measures pushed by donors and the World Bank in the 1990s and expressed by the Government in its policy papers eventually coalesced in a watershed Bylaw enacted in 2002, under which the WAJ was reaffirmed as the only legal entity allowed to issue drilling licenses to users. Legal well owners have to renew the abstraction licenses yearly, by paying 


\section{Chapter 6}

$50 \mathrm{JD}$. Licenses specify the type of use and the area of land to be irrigated (it is illegal to irrigate more than one land plot or property with a given licensed well). In order to obtain a license, the land area to be irrigated has to be larger than 10 ha and the minimum distance between wells has to be $1 \mathrm{~km}$. The authority has the right to backfill the well if groundwater is sold as drinking water without a special permit, when wells have been drilled without a license, or if well owners do not comply with the terms of the licenses/permits granted.

An owner can also apply for a permit for cleaning, deepening and/or changing the location of an existing (licensed) well. Theoretically, a license for a new well is only given after the original well has been backfilled. Following the bylaw, each well has to have a metering device and the well owner should inform the WAJ within 48 hours if the meter stops working.

Transitional measures were necessary to take into account pre-existing illegal wells. Wells ended up classified into four types: 1) legal wells with a license (rukhsa) from the WAJ; 2) illegal wells registered in the WAJ database but which got a permit (ijaza) when it was considered that "there are economic or social factors justifying continuation of water extraction"17; 3) registered wells which did not receive a permit; 4) illegal wells unknown to WAJ (or to which they turn a blind eye) (not explicitly referred to in the law) ${ }^{18}$. Wells with permits drilled on a land without official title may be regularized if/when private land ownership is confirmed. Permits are renewed every 3 years (at the cost of JD150) and WAJ has the right to modify or cancel them.

The Bylaw 85 introduced block-tariffs for groundwater, which vary with the type of wells (Table 6-1). Licensed wells were granted a generous free block of 150,000 $\mathrm{m}^{3} /$ year and rather limited tariffs for blocks beyond this volume. Areas with saline water are granted lower tariffs (on account of associated low agricultural revenues). Illegal wells, by contrast, faced much higher tariffs starting from the first cubic meter. Wells with permits stood in the middle with a free block of, generally, 50,000 $\mathrm{m}^{3}$. If a well has no meter, the abstracted amount can be estimated by WAJ according to the irrigated area, cropping patterns, or the energy consumption of the pump (if there is any electric connection).

Several amendments to the Water Bylaw have been made in 2003, 2004, 2007, 2013 and lastly in 2014. In 2003 the WAJ modified the tariff of the second block for legal wells (from 5 fils $/ \mathrm{m}^{3}$ to $25 \mathrm{fils} / \mathrm{m}^{3}$ ), which generated political opposition and the intervention of some members of parliament who exerted political pressure on the then Minister of Water (interview with official, 2015). The rise was eventually cancelled by another amendment in 2004 (Addustour, 2004).

\footnotetext{
${ }^{17}$ Against payment of a fee of $150 \mathrm{JD} /$ meter of well.

${ }^{18}$ Recent official data indicates that Jordan has 1,559 (identified) illegal wells, out of which more than 50 wells are owned by influential people (such as former ministers, former parliament representatives, senators, and former political and royal councilors) (Sawaleif, 2015), which seems an understatement if judged from the situation observed in Azraq.
} 
Table 6-1. Water tariff for registered and unregistered wells (Bylaw 85-2002/4, and amendment 2014) $\left(1 \mathrm{Km}^{3}=1000 \mathrm{~m}^{3}, 1 \mathrm{JD}=1000\right.$ fils $\left.=1.21 \mathrm{US} \$\right)$

\begin{tabular}{|l|c|c|c|c|}
\hline Water blocks & $\begin{array}{c}\text { Wells with } \\
\text { license/permit } \\
(2002 / 4)\end{array}$ & $\begin{array}{c}\text { Wells with permits } \\
\text { in Azraq (2002) }\end{array}$ & $\begin{array}{c}\text { Illegal wells } \\
\text { (registered) (2002) }\end{array}$ & $\begin{array}{c}\text { Illegal wells } \\
\text { (registered) (2014) }\end{array}$ \\
\hline $0-10 \mathrm{~K} \mathrm{~m} \mathrm{~m}^{3}$ & Free & Free & Free & 25 fils $/ \mathrm{m}^{3}$ \\
\hline $10 \mathrm{~K}-30 \mathrm{~K} \mathrm{~m} \mathrm{~m}^{3}$ & Free & Free & Free & 35 fils $/ \mathrm{m}^{3}$ \\
\hline $30 \mathrm{~K}-50 \mathrm{~K} \mathrm{~m} \mathrm{~m}^{3}$ & Free & Free & $25 \mathrm{fils} / \mathrm{m}^{3}$ \\
\hline $50 \mathrm{~K}-100 \mathrm{~K} \mathrm{~m} \mathrm{~m}^{3}$ & Free & $20 \mathrm{fils} / \mathrm{m}^{3}$ & $30 \mathrm{fils} / \mathrm{m}^{3}$ & $35 \mathrm{fils} / \mathrm{m}^{3}$ \\
\hline $100 \mathrm{~K}-150 \mathrm{~K} \mathrm{~m}^{3}$ & Free & $60 \mathrm{fils} / \mathrm{m}^{3}$ & $35 \mathrm{fils} / \mathrm{m}^{3}$ & $35 \mathrm{fils} / \mathrm{m}^{3}$ \\
\hline $150 \mathrm{~K}-200 \mathrm{~K} \mathrm{~m} \mathrm{~m}^{3}$ & 5 fils $/ \mathrm{m}^{3}$ & $60 \mathrm{fils} / \mathrm{m}^{3}$ & $70 \mathrm{fils} / \mathrm{m}^{3}$ & $35 \mathrm{fils} / \mathrm{m}^{3}$ \\
\hline$>200 \mathrm{~K} \mathrm{~m} \mathrm{~m}^{3}$ & $60 \mathrm{fils} / \mathrm{m}^{3}$ & $60 \mathrm{fils} / \mathrm{m}^{3}$ & \\
\hline
\end{tabular}

\subsubsection{Amendments to the 2002 Groundwater Bylaw and Law No 18 of 1988}

The establishment of water tariffs and quotas with the aim of influencing behaviors and controlling abstraction was a bold step, since there is no other place in the world where administered prices for groundwater have been set up with such an objective (see Molle and Closas, 2017). This policy, however, has been weakened from the start because farmers tended not to pay their bills and regulation was not enforced; some wells had meters installed by the WAJ but others not; farmers' tampering with meter was widespread; the consumption figures collected on the ground were distorted by different mechanisms clarified later in this article. On the other hand, the generous free block and the relatively low water tariffs made this payment for water modest compared with actual pumping costs or incomes, which defeated the measure (Venot and Molle, 2007).

The 2007 Amendment indicated that a permit might be obtained if the well owner had asked for a settlement with the MWI before July 2005. Well owners in this case had in general dug a well illegally because their land was not legal, expecting their land to be legalized later through a settlement procedure carried out by the DLS (Department of Land Survey). The 2014 Amendment went one step further and specified that all the wells not having initiated such a process of regularization before 2005, as well as all other unlicensed wells, should be backfilled by their owners at their cost and under the supervision of WAJ. Failing this, the WAJ would close them (with police or border patrol support if necessary). Farmers should also install metering systems and new (minimal) quotas were issued for registered illegal wells. Corresponding tariffs were dramatically raised, to the point of virtually making any use unprofitable, showing the government's resolve to end illegal wells. In 2014 the WAJ started closing illegal wells, first acting, however, upon the non-working or unproductive wells.

Other important policy measures were introduced through an amendment of Law No 18 of 1988 (also in 2014):

- Farmers cannot initiate or request anything from the administration until all due water bills are paid.

- The penalty for drilling illegal wells was changed from 6 months to two years in prison to one to five years, with a payment of 2000 to 7000 JD; while not respecting the 
conditions of the license would attract fines between 1000 JD and 5000 JD and prison between one and three years.

- Illegal abstraction will be estimated according to the cultivated area, cropping pattern, energy consumption, or remote sensing images, and charged to the user.

Current policy objectives are well delineated in the 2008-2012 national Water Strategy (HKJ, 2009), which emphasizes the willingness to enforce by-law 85/2002 and a strict monitoring of groundwater use, introduce metering, use tariffs to discourage planting crops with high water requirements, and close down illegal wells.

\subsection{Methods and context of the case study}

\subsubsection{Methodology}

The present case study on Jordan's highland focuses on the aquifer of Azraq basin (with the two distinct areas of Azraq proper and Mafraq). Fieldwork was carried out in 2013 and 2014, and included interviews of 80 farmers (local residents, investors, past farmers), line agencies personnel, wetland manager, and local leaders, completed by semi-structured interviews of nine policy makers, staff in water, land and agriculture administrations, and water experts in Amman (2014 and 2015). The questionnaires covered issues of land tenure, cropping patterns, production, water and energy sources and use, animal breeding, crop/farm budgets, future perspectives on Azraq, and responses to/perceptions of water policies. Because of the sensitivity of the topic and the reluctance of some interviewees to be cited, the information gathered is anonymized and interviewees are referred to as either 'Official' or 'Farmer'. Additional information is drawn from newspapers and the general literature.

\subsubsection{General physical features of Azraq Basin}

The Azraq Basin is located in the North-eastern part of the country with an area of 12,710 $\mathrm{km}^{2}$ (Figure 6-1). The largest part of the catchment (94\%) lies in Jordan with smaller parts in Syria (5\%) and Saudi Arabia (1\%) (Shahbaz and Sunna, 2000). The basin is a semi desert area characterized by a hot and dry summer and fairly wet and cold winter. The mean annual rainfall ranges from $50 \mathrm{~mm} / \mathrm{yr}$ in the Azraq Oasis area to $500 \mathrm{~mm} / \mathrm{yr}$ in Jabal Al Arab area, with an average of $87 \mathrm{~mm} / \mathrm{yr}(J M D, 2011)$. The average potential evaporation rate in the area is $2,400 \mathrm{~mm} / \mathrm{yr}$ (El Naqa et al., 2007). The dominant soil type in the region is a silty clay loam soil with high soluble salt content in the subsurface horizon.

The Azraq basin consists of three aquifer systems (upper, middle and deep aquifers) that are hydraulically connected in certain parts. The depth of groundwater in the upper aquifer varies from a few meters in the center of Azraq oasis to $400 \mathrm{~m}$ in the northern catchment area. The Azraq basin safe yield has been established by the Ministry at $24 \mathrm{Mm}^{3} / \mathrm{yr}$ (Demilcamps, 2010; MWI, 2009), while the total estimated recharge is about $34 \mathrm{Mm}^{3} /$ year (Bajjali, 1990; MWI, 2010). Groundwater flow moves from the north east and south west of the basin to its centre, the qa'a, that is, the depression where a permanent wetland was initially found (Figure 6-1). Likewise rainfall generates runoff that flows in the same directions through wadis and accumulates in the qa'a, while recharging the aquifer. 


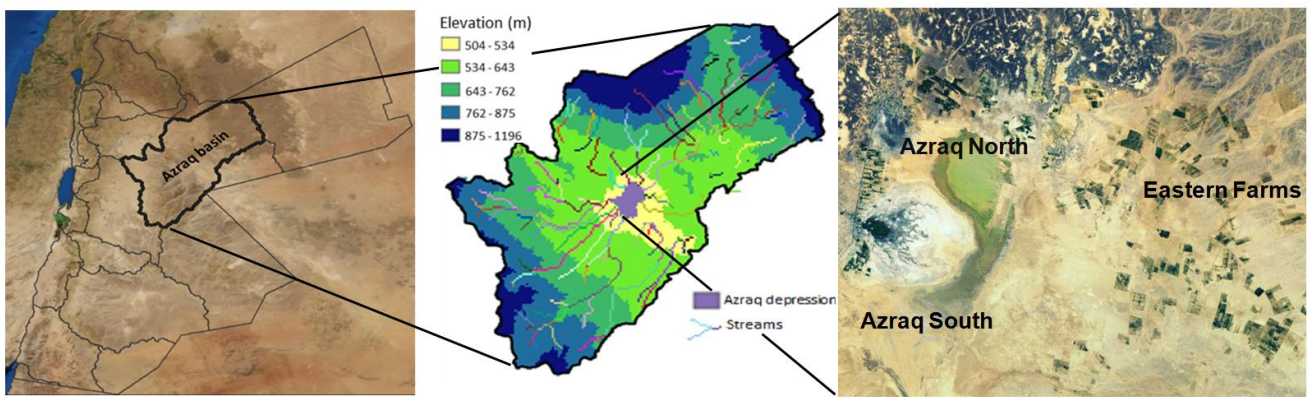

Figure 6-1. Azraq basin elevation and streams

\subsubsection{Azraq oasis and communities}

Three main communities are found in the Azraq basin: Chechens, Druze and Bedouins. Even though Bedouins were mostly pastoralists, some of them started farming when agriculture boomed in the area. Others preferred to work as land brokers. At the beginning of the $20^{\text {th }}$ century Chechen and Druze settled in the city centre, close to the natural springs, the former in the south and the latter in the north. Most Chechens engaged in farming but agriculture's productivity remained limited by the relatively saline groundwater found in the lands located near the central mudflat (Qaá).

The Azraq Oasis (or Azraq wetland) initially had a naturally flooded area of $12000 \mathrm{du}$ and was declared an international Ramsar site in 1977 (Al-Eisawi, 2012). It was an important reserve for migratory birds and a breeding site for about 70 bird species. The oasis was fed by surface runoff but sustained during the dry period by three springs which eventually dried up in 1992 (Daoud et al., 2006), due to intensive pumping for agriculture and water supply to Amman. This caused the deterioration of the wetland and a decrease in the flooded area, leading to an environmental catastrophe and a reduction of the site's tourist attractiveness. The oasis is now artificially recharged with groundwater supplied by one public well and covers $10 \%$ of its original extension (Hresha, 2013).

\subsubsection{Agriculture and the water situation in Azraq basin}

Initially, subsistence agriculture depended on traditional surface irrigation techniques and shallow dug wells with low abstraction rates. Modern groundwater-based agriculture developed in the 1970s/80s with the introduction of diesel engines (Venot and Molle, 2007); the availability of modern irrigation techniques such as drip and sprinkler irrigation systems (MWI, 2015a, 2015b); improvements in well-drilling techniques; subsidized energy costs; cheap and easy access to land and water licenses (MWI, 2015a, 2015b), good water quality, and very favorable export market conditions, especially to Gulf countries (USAID, 2014). These factors contributed to making agriculture a prime investment option in the highlands in general and Azraq in particular.

The expansion of agricultural land continued in the 1990s with the introduction of new irrigated cropping patterns in Azraq, including grapes, and pomegranates later in the early 2000s, farmers diversifying away from olive trees. Although water salinity problems resulted in a few farms being abandoned, especially in south Azraq area (Demilcamps, 2010), agricultural expansion continued in north and east Azraq, with deeper drilling and a typical 


\section{Chapter 6}

drawdown of the aquifer by one meter per year and the introduction of new crops such as date palm and alfalfa. According to the Ministry of Agriculture, and despite the toughening of state regulations, the cultivated area increased, between 2005 and 2011, from 61200 du to $114,330 \mathrm{du}$ (MoA, 2012).

Although desert land is officially state land, Bedouins consider it as their tribal land and while some of them found in agriculture a good investment, others 'sold' their land to investors from Amman, Iraq or the Gulf countries. A key driver of the expansion of land cultivation in Azraq is therefore land speculation, with tribal leaders mediating the (paid for) transfer of land to investors moved by the returns of agricultural and/or (more often than not) speculative motives, claiming land in the hope that it will be later regularized, with its value increased many-fold (Humpal et al., 2012; Al Naber and Molle, 2016). But well drilling is costly (especially in Mafraq where depths of $350 \mathrm{~m}$ are common) and establishing a $200 \mathrm{du}$ farm with drip irrigation costs around half a million JD.

Azraq groundwater is also a major source of drinking water for Amman, Irbid and Zarqa as well as the Azraq area itself. Via a series of well-fields, the government abstracts about 23 $\mathrm{Mm}^{3}$ of groundwater from the Azraq basin every year for drinking purposes (WAJ, 2010), while agriculture abstracts around $28 \mathrm{Mm}^{3}$, nearly the equivalent of the basin's safe yield (24 $\mathrm{Mm}^{3}$ per year) (MWI, 2009). This clearly indicates the magnitude of the challenge of achieving sustainable use, since this means that agriculture should be basically discontinued. ${ }^{19}$ The total abstraction is estimated at $215 \%$ of the safe yield (MWI, 2009), but two recent studies conducted in the Azraq basin have found that actual groundwater use for agriculture in the basin exceeded twice the official recorded data (Al Bakri, 2015; USAID, 2014).

\subsection{Policies in action: local practices in the Azraq Basin}

Laws and regulations have been introduced in order to monitor and control groundwater abstraction. After presenting Jordan's water policies and the context of Azraq, this section illustrates the common gap between formal policies -on paper- and local practices, identifies enforcement difficulties, and analyzes the tactics adopted by Azraq groundwater users in response to these policies. (The information has been provided by farmers or officials/experts; when this is not the case the reference is given.) The strategies pursued are to evade taxation and circumvent restrictions on groundwater use, whether at the extensive margin (new illegal wells) or at the intensive margin (consumption from an existing registered well).

\subsubsection{Farmer tactics to circumvent regulations}

\subsubsection{Well licenses and permits}

Farmers without legal land titles have dug wells and obtained a permit for their illegal (but registered) well. Some farmers later legalize their land through 'settlement or 'delegation' processes (see Al Naber and Molle, 2016) and then legalize the well accordingly. But this is now constrained by the fact that any well considered should have been drilled before 2005 .

\footnotetext{
19 Unless abstraction for domestic use is reduced. WAJ's promise to do so once water from Disi aquifer would reach Amman has not been kept, officially due to the pressure on water resources added by the refugees.
} 
Legalizing land/wells substantially increases the value of the land and, as mentioned before, the water tariff for legal wells has a generous 'free block' and is much lower than for illegal ones. Farmers are therefore bent on legalizing their wells by either exerting pressure on the DLS to have their land status corrected (Farmer, 2014), or making the farm where the well is dug look older than 2005 in order to be able to claim land in case a settlement procedure is announced. It was reported that fake land deeds were also used to obtain a license for a well.

\subsubsection{Well maintenance (cleaning, replacement and deepening)}

Three types of well maintenance can be done for licensed wells: well cleaning, well deepening and well replacement. Well cleaning is used to remove plants, roots, earth or anything that can have an effect on water quality and pumping. Well deepening is made necessary by the drop in the water table. Well replacement is accepted if there are technical problems with a well. Each well maintenance procedure needs a specific license from the WAJ.

Some informants indicated that these lawful operations are used to bypass the 1992 drilling ban (later officialized in the 2002 bylaw): some apply for a well cleaning license but instead deepen the well to get more water (especially if groundwater is saline in the area); others, who obtained a well deepening license, do not respect the stipulated depth. Farmers can also seemingly damage a working well in order to be able to apply for a replacement license. They may fill it with soil or obstruct it superficially, so that when the WAJ inspects it a replacement license is approved. After the new well is drilled they remove the obstacles and open the old well again.

\subsubsection{Metering systems}

As indicated in the bylaw each well must have a functioning metering system, but the reality is far from the theory (Fitch (2001) found that a few years only after having been installed $40 \%$ of the meters were out of order). In many farms visited during the fieldwork wells were found without a metering system. Some farmers complain that their meter is broken and is not working, while others would tamper with the meter so that it records less water consumption (for example by using a drill to rewind the meter backward). Some farmers would also bypass the meter with a parallel derivation pipe, so that not all the water pumped is metered.

It is also indicated that the WAJ should visit the wells every 3 months to take meter readings. This is clearly way beyond the capacity of its limited staff (there are 420 working wells with licenses or permits in Azraq, and as many 'non-working' wells), and frequency is rather every year. Some are asked their readings by telephone.

\subsubsection{Requesting a well for domestic or industrial use}

Drilling new agricultural wells was banned in 1992. Some farmers then tried to apply for domestic or industrial well licenses to dig a well, and later use it for agricultural purposes. 


\section{Chapter 6}

\subsubsection{Sealing wells}

It was already stipulated in the 2003 amendment that illegal wells without permits should be backfilled within six months, but such measures were not implemented. A government campaign to close illegal wells started in 2013. In some cases well users would use a fake well with a pipe in the ground pretending to be a well and would have it sealed. The original well would be reopened after the inspection. Another reported technique is to insert in the well a smaller pipe, which is only a few meter long and closed at the bottom end. After being filled in and obstructed with earth and rocks, the pipe is later removed to make the well operational again.

\subsubsection{Hiding illegal wells}

Farmers can drill illegal wells to make for a declining existing (registered) well, or to mix waters when the existing well is getting more saline, and/or to expand cultivation. This is why it is common that farmers with one (or several) licensed wells also have additional illegal ones. Another reason is the rule that a farm can only be irrigated by one given well, which means that larger farms are all likely to have illegal well alongside a legal one.

The relationship between a well and the irrigated area is not always straightforward, especially if the well is not metered and its yield therefore unknown. This also helps hiding additional illegal sources of water. Such wells are also dissimulated and hidden (such as the case reported by a MWI official of a well in the Jordan Valley that was hidden under the bed of the owner), covered with plants or rubbish; or the road reaching the farm can be cut in order to prevent easy access by officials (Addustour, 2004).

\subsubsection{Bribing}

The transaction costs of checking the situation on the field (existence or effective use of a well, meter readings, etc) are quite high. WAJ only has three staff in Azraq who can engage in monitoring tasks, which is clearly insufficient to carry out what is expected from them.

Some farmers will also pay for WAJ staff to underestimate the meter readings or to turn a blind eye to an illegal well. Such practice is likely to be quite widespread, judging from the gap recently found between official and estimated abstraction figures. The social proximity of WAJ staff and farmers in some cases (they are from or live in the same area) can also limit the effectiveness of rule enforcement and control.

\subsubsection{Social power and intimidation}

In other cases, WAJ staff work is made difficult by intimidation tactics (cases where visits are discouraged by a show of weapon), or by display of social power by some influential land owners. As illustrated by one interviewee's comment on a Bedouin farmer "it is a tribe and the tribe has power; the small government employee cannot say no to the big tribe". An example, reported during the interviews, was a case in which three farmers attacked WAJ staff during a field inspection, opening fire and injuring one of the staff. Abbadi (2003) recorded eight similar attacks but without injuries. 


\subsubsection{Transfers of water}

Although it is prohibited to use water from a well in a farm that is not the one cultivated by the owner of the well, some farmers have circumvented the difficulty to drill new wells by transferring water by pipe from neighboring legal or illegal wells, over distances that can reach several kilometers. If these wells are not metered, abstraction is calculated based on the nearby cultivated area (only) and can therefore be greatly increased. This transfer can be paid for but, in a case observed in Mafraq, an investor had to supply his Bedouin neighbor, for fear of reprisals if he did not agree.

\subsubsection{Dividing the land}

Article 30 in the bylaw states that it is "prohibited to grant more than one drilling or extraction license for one plot of land". To evade this measure, Bedouin sheikhs occupying or claiming large tracts of land which cannot be irrigated by one single well divide their land between their sons or relatives.

\subsubsection{Illegal drillers}

The Ministry is trying to monitor and control the presence of illegal drillers by introducing tougher penalties on those drillers. But these drillers also find ways to circumvent the law. Some hide the drilling machines between trees, others install it on a broken machine said to be out of order and use it at night (Addustour, 2013). A recorded witness highlighted that one driller with the help from some locals tried to cut the road to get time enough to hide the drillers before WAJ visit. New types of rigs can now be loaded upon and transported by a pickup and are more difficult to spot (interview with official, 2016).

\subsubsection{Policy responses by the government}

Faced with a situation of insufficient monitoring and enforcement, the MWI has tried to toughen its stance and practices, and developed several parallel 'counter-measures'.

\subsubsection{Departmental coordination}

After the passing of the 2002 bylaw, groundwater tariffs were increased in 2003, and then decreased in 2004, so farmers did not take the new law amendment seriously and most of them did not pay. In July 2009 WAJ distributed the bills again, covering the period from 2003 to 2010. Some farmers still refused to pay their bill while others did. In 2014, the government sought to interconnect all governmental departments by a computerized system, so that any governmental procedure (purchase transaction, passport or driving license request, etc) would be refused, had the farmer not paid his water bill. This is in particular the case for farmers willing to hire labor for their farm (the approval of the Ministry of Agriculture being made conditional upon payment of the water bill), or willing to sell their land.

\subsubsection{New water tariffs}

Illegal well drilling thrived in the past 20 years and WAJ tried to tackle existing illegal wells by introducing a new and very high water tariff in 2014 (Table 6-1). It is hoped that this new tariff combined with the administrative measure described above will strongly discourage farmers from drilling new wells, and will force them to either use little water so that they stay 


\section{Chapter 6}

in the lower tariff blocks $\left(30,000 \mathrm{~m}^{3}\right)$ or discontinue operation. This measure acknowledges the difficulty to backfill illegal wells and attacks them through taxing and the indirect enforcement measure described above.

\subsubsection{Controlling drilling companies}

The registration of drilling companies and the conditions/constraints established for their activity have been specified in the 2002 bylaw. Equipment spotted while carrying out illegal drilling is liable to seizure. Official statistics mention the number of rigs seized every year and such actions are frequently reported in newspapers. In 2013, the Ministry confiscated 14 illegal drills (Assawsana, 2015) and repeatedly publicized its action in the newspapers. It is not clear, though, how much of a deterrent to illegal well drilling this is since similar announces were also made in 2003 in the wake of the bylaw (Addustour, 2004).

\subsubsection{Satellite imagery}

MWI is now using satellite imagery to control the expansion of cultivated area and illegal well drilling. Satellite imagery also allows for a comparison between reported abstracted volumes and water requirements estimated based on the cultivated area and crop type. Recent studies (AI Bakri, 2015; USAID, 2014) have indicated that abstracted volumes were seriously underreported, prompting a toughening of the policies pushed by the Minister.

Satellite imagery was used as far back as 20 years to check cultivated areas (and was already mentioned in the 1988 law - Article 30). However, the situation has now significantly changed because of a dramatic drop in the price of these the images, a much easier availability, and more powerful computer processing. They can now indicate yearly changes and even spot pump houses on the fields.

\subsubsection{Destroying illegal wells}

The law indicates that illegal wells should be backfilled at the cost of the well owner. Given the different user tactics to avoid control and well sealing discussed above, the Minister has decided to use dynamite to close wells, to ensure that they cannot be used again, while ordering pictures to be taken for each case.

\subsubsection{Stopping land settlement processes}

Opening a 'settlement' or 'delegation' procedure (where state land ownership or use is transferred to individuals) encourages Bedouins and investors to claim more lands in the hope to see this land eventually legalized as private property. Land 'ownership' (that is, occupancy) has to be proved either by cultivating the land or by building a house on the land plot. Most people choose the first option as it is easier and the loss more limited if that claim is not accepted and their cultivation destroyed by the government. In 2010 a rumor went around Azraq saying that the government would release more land for farming. As a result, people started claiming state lands and planting trees (sometimes old ones to pretend that the farm was old), and 16000 du of new land ended up "cultivated" in Azraq within 2 weeks. The Ministry was able to remove 10000 du of newly cultivated land but the other $6000 \mathrm{du}$ remained as they were cultivated by an influential sheikh from the Bani Sakher tribe. During an attempted visit to the land by the Ministry, the sheikh used weapons to intimidate the 
visitors. As a result of such a situation settlement and delegation processes in Azraq, and more generally in Jordan, were discontinued by the DLS.

\subsubsection{Naming and blaming}

The Ministry started a new procedure for unpaid bills. Officials claim the unpaid amount from the well owners and give them a period of 15 days to pay. After that, the Ministry publishes the names of the well owners and the unpaid amount in the newspapers (including the Official gazette) and gives them an additional period of 60 days to settle down the charges. If the owner still refuses to pay the amount then the Minister has the power to seize the account of the well owner (Alwakeelnews, 2015; Khaberni, 2014). At the end of 2015 the Ministry had already published a first list of 70 well owners in the official newspapers. Unsurprisingly, some of them are well known and influent people in Jordan (owing, for some of them, more than 200,000 JD of unpaid water bills) (Mbayden, 2013; Khaberni, 2014). In Azraq only, the Ministry sent 495 notifications for water payment, out of a total of 1493 (Alwakeelnews, 2015). The Ministry has also opened the possibility for well owners to settle unpaid bills by installments (Sarayanews, 2013).

\subsubsection{Cutting other benefits}

Another important decision taken by the Ministry has been to stop giving agricultural loans or credits to illegal well owners and to cut off the electricity supply to farms with illegal wells. Also, through the Ministry of Agriculture, owners can be refused labor permits (when it comes to employing full-time workers) (Petranews, 2014).

\subsubsection{Constraining access to labor}

The registration of the cultivated plots with the Ministry of agriculture gives the right to the investor to 'import' farm labor (in general from Egypt), with a generous allocation of one worker per $10 \mathrm{du}$, and even $5 \mathrm{du}$ if one cultivates vegetables. Someone with $200 \mathrm{du}$ irrigated theoretically has the right to 20 workers, although he might only need two or three in practice. This surplus labor can be transferred to the construction sector, for which middlemen will pay between 300 and 800 JD to the farmer for letting go one of 'his' workers (the monthly salary a worker is 300-350 JD in Azraq, but 750 in the construction sector in Amman). This 'labor market' also gives way to bribes and faulty reporting of cultivated areas (to maximize the number of workers). But this 'right' has now been reduced to one worker for each $50 \mathrm{du}$. And a new law has been passed to disallow the granting of work permits to farms with illegal wells.

\subsubsection{Raising awareness}

The Ministry has also been using public debates, publishing a series of articles highlighting the water problem in the country, and public awareness-raising campaigns and school programs (Subeh, 2006). Such campaigns have also been directed at judges and imams. Actions such as seizing rigs, sealing illegal wells, fining people for illegal fixtures on mains are repeatedly and insistently publicized in the newspapers since 2013; the Minister of Water and Irrigation also makes frequent appearances on TV channels (El Naser, 2013). In 2014 there were more than 15,000 cases of groundwater-related offenses reported by the WAJ, 


\section{Chapter 6}

some for tampering meters, others for digging illegal wells, or sabotage of WAJ's water distribution pipes (Jordannews, 2015).

Also, the King formed a Royal Commission on water resources in 2008, which issues frequent reports describing the country's water situation and needed strategies to conserve water (PM, 2008), directed to the public but also to members of Parliament.

\subsection{Discussion and conclusions}

Since the first ban on agricultural wells in 1992, Jordan has experimented with a wide range of regulations and policies aimed at controlling groundwater abstraction in the country, most notably in the Highlands. The 2002 bylaw has been seen as a watershed legislation but implementation on the ground has been lacking and the drilling of new wells has continued unabated, fuelled by the profitability of irrigated agriculture as well as land speculation. To deal with pervasive problems of illegal well drilling, meter tampering, and unpaid water bills the government has used both direct and indirect tools.

Direct measures include well licensing, establishing annual quotas per well, sealing illegal wells (and destroying them with dynamite), licensing and monitoring drilling companies, limiting the number of well licenses to one per plot of land, banning well drilling for agriculture. Indirect measures include a block tariff pricing system, increasing the water tariff of illegal wells, constraining the granting of labor permits, publishing the names of violators in newspapers and publicizing tough actions on the ground, using satellite imagery to estimate and charge water consumption, and improving inter-departmental coordination to force users to pay water bills.

Application of direct tools in the fields proved to be bedeviled by the transaction costs of reading meters, checking the existence and characteristics of wells, or demanding payment. Such direct enforcement requires heavy presence in the field, something that clearly exceeded the capacity and the material means given to WAJ few field staff, not to mention the constraining factors associated with the social proximity of WAJ staff and farmers, incentives to bribery, intimidation by local Bedouins, and the feeling that the degree of resolve of higher-level authorities in enforcing the law was wavering. Direct metering, a standard recommendation of groundwater policy packages, appears to be more of a conduit for corruption than any kind of real monitoring. Indirect metering through satellite imagery is being developed at the moment in the Ministry and provides a better solution in a desert environment where cultivation is clearly visible. Acting forcefully on illegal agricultural wells in use and on tree plantations proved to be politically problematic. The Chinese case described by Aarnoudse et al. (2012) remains a kind of exception linked to exceptional circumstances (Molle and Closas, 2017). The backfilling of illegal wells used to irrigate crops, particularly trees, is almost unheard of (ibid.). As a result the Ministry concentrated its action on the violations on water supply mains, including illegal fixtures on the Disi-Amman pipe, on reducing non-revenue water in urban networks (still around 50\%), and put a greater emphasis on indirect tools.

Indirect tools such as reducing the attractiveness of land reclamation (stopping settlement processes) and constraining it (through denying labor permits or connections to the electricity grid for illegal wells), are sound measures. Water pricing, however, has proved marginal if not illusory with regard to legal well owners for whom it is hard to justify high 
levels of taxation. The Ministry, in 2014, therefore concentrated the tool on illegal wells, with tables of tariffs that make open-field cultivation virtually impossible. But a (too) big stick becomes hard to use and it is not yet clear whether the measure will succeed in phasing out illegal wells. Exacting payment of such massive bills is uneasy but the Ministry has come up with a very innovative additional stick by connecting the various administrations (and making any procedure dependant upon the settlement of the water bills) and even threatening to freeze the accounts of violators (whose names are published in newspapers).

Even though the law should target all users equally, some farmers in Azraq complained that the government was selective and enforcing the law only onto them. This raises the crucial issue of the political economy of policy implementation. Political considerations explain why some of the instruments have been lacking 'teeth' (for example the overly generous 'free block' of the water tariff -it is now envisaged to halve the free allowance-, the leniency towards illegal well drilling or meter tampering, land encroachment, etc.). The country largely holds thanks to the support of tribes and investors, both being the main actors of land and water development. The tribal politics of Jordan and their constitutive role in state-building, have been the subject of much scholarship (Alon, 2007; Kark and Frantzman, 2012). The Crown, in order to win their support to the new Hashemite power, has always been engaged in a give-and-take relationship with local tribes, a crucial balancing act for the sustainability of the regime. Likewise many high-ranking officials and wealthy individuals have stakes in the land reclamation business, and therefore in accessing the key factor that makes it possible: water (Zeitoun et al., 2011). Last, settlers and smaller scale farmers - more generally rural dwellers - are often suffering from the current political and economic situation, making it politically costly to antagonize them, especially in the wake of the Arab Spring in the region.

Several factors, however, are slowly reshuffling the cards. First, groundwater is increasingly considered as a key strategic resource to ensure domestic water supply, the Minister emphasizing publicly that the alternative sources (through desalination or the Red-Dead project) will be six to seven times more costly (El Naser, 2013). Second, there is a growing awareness of the water crisis among Jordanian citizens in general and politicians in particular (as expressed by a MP interviewed). Outrage at the violations on the Disi pipe and water mains slowly extends to illegal wells, undermining the overall tolerance for abuses. Some powerful people have been heavily fined, named and shamed in the newspaper, which is certainly a rare instance in the MENA region in general. Last, the current Minister has shown an exceptional level of leadership in attacking the problem of several fronts, while securing high-level support, not least from His Majesty the King. While donors (most particularly USAID), had been influential in the past in pushing for measures such as metering and tariffs, there is a feeling that the government is now coming to grips with an issue that threatens the country's stability.

Although it is too early to make a definite assessment of the policy reforms recently undertaken, a few important lessons that are relevant to the region and beyond can be mentioned. First direct measures are hard to implement on the ground and often overestimate the power of the state to act on the ground; this is in particular the case of metering which can be replaced by indirect measurement through remote sensing imagery. Second, too big 'sticks' (sealing wells or prohibitive water tariffs), while signaling the gravity of the violation, may turn out to be non-credible and even counterproductive (by pushing people into illegal solutions). Third, the creative tools deployed (administrative 


\section{Chapter 6}

interconnection, naming and blaming, etc) may be inspirational for other countries. Fourth, aggressively raising awareness not only of citizens but also MPs, judges or imams may well bear fruit over the long term. Last, it is hard to assess the effectiveness of each measure and it is likely that success depends on both articulating a diversity of tools and the advent of a felicitous mix of leadership and high-level support. Whether the resolve currently shown by the Ministry, buttressed against a growing sense of urgency and water crisis, will succeed in balancing private interests remains to be seen, and also exposed to being overturned at any time due to the region's political volatility. 


\section{CHAPTER SEVEN}

\section{Water and Sand: is Groundwater-based Farming in Jordan's Desert Sustainable?}





\title{
7 Chapter Seven: Water and Sand: is Groundwater-based Farming in Jordan's Desert Sustainable?
}

\begin{abstract}
Irrigated agriculture in Jordan's highlands relies on overexploited groundwater. Drops in water tables and water quality, but also tougher policy measures by the government, threaten the sustainability of this activity which has long thrived on lax law enforcement and cheap desert land. This paper is based on field work in two locations of Azraq groundwater basin [around the Azraq oasis and in the northern part (Mafraq)], and first presents farm typologies which show the variability of farm gross margins and the contrast between the two zones. While Mafraq stands for capital-intensive fruit-tree cultivation on legal land/wells, Azraq's agriculture is largely based on olive cultivation and wells that are either illegal or granted permits with higher block tariffs, and has a return that is only one tenth of Mafraq's. The paper reviews the constraints and changes in land, energy, water, labor and input costs and reflects on their bearing on current dynamics and future prospects. While Mafraq is found to be largely immune to policy changes and resilient to foreseeable changes in factor prices or markets, Azraq's future is threatened by various vulnerabilities, including salinization of groundwater, rising energy and labor costs that, in the long run, are likely to be overcome only by farmers emulating the Mafraq intensification model, or accepting temporary losses in the hope of a future legalization of land and wells. Solar energy now emerges as a trump card, in particular for illegal farms which, on the other hand, are challenged by recent tough water pricing regulations that are shown to make them unprofitable. The government's resolve in enforcing these regulation is put to test and will largely decide the future of Azraq's agriculture.
\end{abstract}

Keywords: groundwater overexploitation, irrigation, farming systems, desert agriculture, Azraq, Jordan

\subsection{Introduction}

The continued expansion of irrigation worldwide in the past 30 years has largely been fuelled by increasingly resorting to groundwater (FAO, 2015). Not only hast the total consumptive groundwater use for irrigation now reached an estimated $545 \mathrm{Bm}^{3} /$ year, that is, $43 \%$ of the total consumptive irrigation water use (Siebert et al., 2010), but the annual contribution of nonrenewable groundwater abstraction to irrigation globally has tripled from 75 to $234 \mathrm{Bm}^{3}$ over the 1960-2000 period (Wada et al., 2012). This situation, where half of groundwaterbased agriculture is unsustainable, is nowhere more explicit than in North Africa and the Middle East, where unsustainable groundwater development for irrigation is taking place in arid or desert land (UNDP, 2013a; FAO, 2015). Whether this groundwater economy will follow a 'soft landing' or a 'crash' scenario is a matter of heightened concern (Gorelick and Zheng, 2015).

In Jordan, groundwater has been used since the early 1960s for different purposes, including domestic, industrial, agriculture and environmental use. The yearly total quantity of groundwater available is assessed by the Ministry of Water and Irrigation (MWI) at $511 \mathrm{Mm}^{3}$, of which $427 \mathrm{Mm}^{3}$ are renewable (MWI, 2013a, 2013b). Irrigated agriculture is the major consumer of groundwater, with $46 \%$ of groundwater going to the agriculture sector, especially in the Highlands. Groundwater-based agriculture boomed in the 1970s and 1980s, 


\section{Chapter 7}

boosted by government policies, favorable export market conditions, subsidized energy, improvements in well-drilling techniques, land affordability and accessibility, availability of good water quality, and transfer of agricultural know-how from the Jordan Valley (MWI, 2009; Demilecamps, 2010). This resulted in the growth of the agriculture sector but gradually impacted groundwater resources in terms of quality and quantity. At present the water abstracted from the two major aquifers of the Northern Highlands -Amman-Zarqa and Azraq- is estimated by the MWI to be above the safe yield by $179 \%$ and $242 \%$, respectively (MWI, 2014).

In the early 1990s the government acknowledged the excessive increase in groundwater use in the highlands and the drop in water tables, and tried to tighten well licensing procedures, banned the drilling of agricultural wells (1992), introduced water meters (mid 1990s), and established water tariffs to be paid by users (2002). Yet the development of agriculture continued unabated, with 710,000 du of land irrigated in the highlands in 2013, against 420,000 in 2000 (DOS, 2015). With irrigated agriculture responsible for 55\% of the country's water withdrawals and $46 \%$ of groundwater abstraction on the one hand, but contributing only $3 \%$ of the GDP on the other, agricultural groundwater use easily comes under criticism.

Jordan's highland agriculture can therefore be looked at through two different lenses: on the agricultural side, questions revolve around who is investing in agriculture, to produce what with what economic results, and the evolution of both drivers and profitability. On the groundwater resource/environmental side, key issues are related to the overdraft and its (uneasy) control, environmental impacts on Azraq wetland, water productivity and the sectoral competition with non-agricultural uses, which are granted a higher priority and claim a larger share of groundwater resources.

This paper builds on earlier work dedicated to farming systems in the highlands, notably Fitch (2001) on Amman-Zarqa basin (AZB) Venot and Molle (2008) on Mafraq and Demilcamps (2010) on Azraq, and first offers a typology of current farming systems as well as an analysis of trends and evolutions in the past 20 years. It then ponders on the challenges faced by agriculture in the highlands through an analysis of its production factors in general, and the implications of recent changes in water policy and regulations in particular. The main questions investigated are: given the pressure and the restrictions affecting input markets, in particular labor, land and water, and the current toughening of groundwater policies, what are farmers' responses and is groundwater-based agriculture in Jordan's Highlands doomed? Or can it weather these constraints, evade regulations, and reinvent itself? The analysis is based on 80 farm surveys conducted in Azraq groundwater basin, and on interviews with different stakeholders, including national and local government officials in the land, agricultural and water administrations, experts, and local personalities. The discussion and the results of the case study speak to the many situations, notably in North Africa and the Middle East, where unsustainable groundwater development for irrigation is taking place (UNDP, 2013a).

\subsection{Setting and methods}

We focus here on groundwater-based agriculture in the highlands of northern Jordan, most specifically on the Azraq groundwater basin, with a few references from the literature on the Amman-Zarqa basin (AZB). As can be seen from Figure 7-1, these two aquifers largely correspond to the Amman-Zarqa and Azraq surface water catchments. The northern tips of 
these two aquifers are located in Syria and although they only make up around 5\% of the total basin areas they correspond to the main recharge areas in Jebel Al Arab (Shahbaz and Sunna, 2000). Figure 7-1 shows the two main agricultural areas covered by this research work: Azraq proper (located around Azraq oasis itself); and Mafraq's Northern Badia district (Mafraq, in what follows), near the northern border, which overlays Azraq aquifer.

Azraq area is located $120 \mathrm{~km}$ northeast of Amman and is part of the Zarqa governorate, with a population of around 12,000 (IUCN et al., 2007). The area is home to two major tribes (Beni Sakhr and Al Sarhan) and to Chechen and Druze minorities who settled there at the beginning of the $20^{\text {th }}$ century (Mesnil and Habjouka, 2012). Azraq Basin is a closed basin, where both surface water and groundwater naturally flow to a central wetland, a Ramsar site of major importance. Because of the excessive exploitation of groundwater for both irrigated agriculture and water supply for Amman, the water table dropped by 0.3-0.8 m/yr (Mesnil and Habjoka, 2012). As a result, local springs dried in the early 90s and the wetland, now reduced to $10 \%$ of its original area, came to be sustained with (public) well water. The depth to (usable) groundwater varies from $20 \mathrm{~m}$ in the center of Azraq Oasis to $350 \mathrm{~m}$ in Mafraq (Abdalla et al., 1999). Azraq basin's safe yield has been established at $24 \mathrm{Mm}^{3}$ per year (MWI, 2009). The main recharge of the upper aquifer system originates from infiltration through the basalt layers from high rainfall areas at Jabal Al Arab in southern Syria (Bajjali, 1990; MWI, 2013a, 2013b).

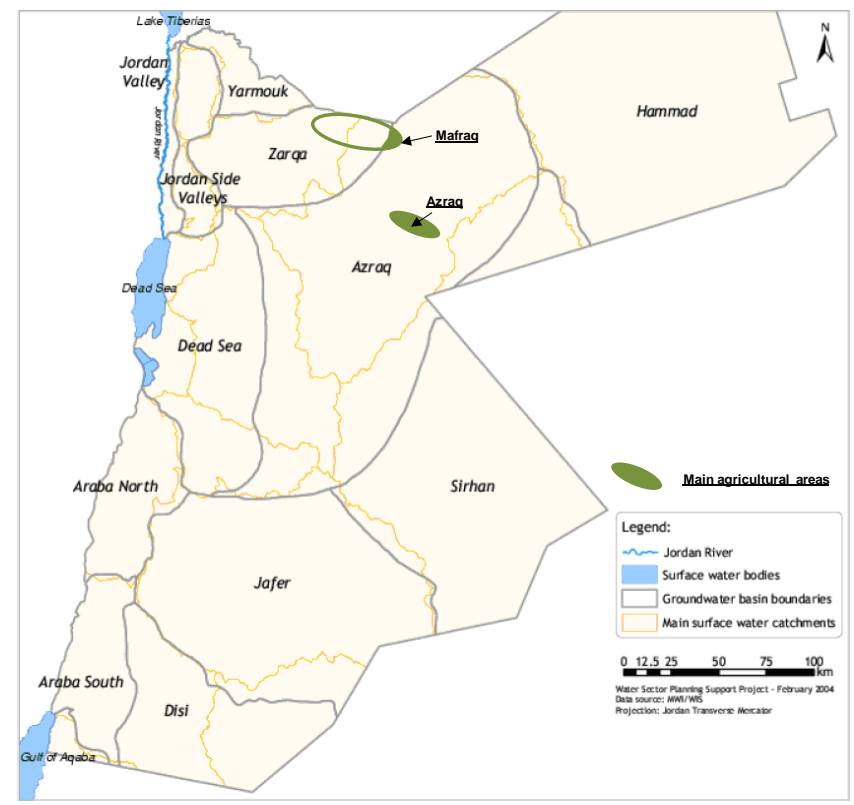

Figure 7-1. Groundwater and surface water basin in Azraq (adopted from Schmidt et al., 2004)

The basin is a semi desert area characterized by hot and dry summers and fairly wet and cold winters (with frost being common). The mean annual rainfall ranges from 100-150 $\mathrm{mm}$ in the west and north of the basin to $50 \mathrm{~mm}$ to the south and east of the basin, including the oasis 


\section{Chapter 7}

itself (JMD, 2011). The mean daily temperature varies from less than $10^{\circ} \mathrm{C}$ in winter to extremes of $45^{\circ} \mathrm{C}$ in summer. Soils are primarily composed of limestone or covered by basalt boulders that resulted from volcanic outcropping (DLU, 1994).

Agriculture first started in Azraq around the oasis, based on the springs' water and shallow dug wells, and then expanded to Ain el Baida, eastern Azraq and Mafraq (Figure 7-2). Thriving on good water availability and cheap land, agriculture in Azraq first appeared as a bonanza. Mobilizing water to transform valueless land into an asset attracted numerous investors, rich urbanites from Amman and abroad with speculative objectives as well as some investors more interested in agricultural production itself. During the mid-2000s the decline in water table levels, the decrease in well productivity, and (localized) increases in water salinity affected farming, with a number of farms being abandoned, especially in south Azraq area that is underlain by a saline aquifer. Nevertheless agricultural expansion continued in Azraq north and eastern farm areas, reaching about 114,000 du in 2011, according to the Ministry of Agriculture. All wells dug after 2005, when the time for the regularization of existing wells elapsed, are considered as illegal and are now the object of increasingly strict measures ( $\mathrm{Al}$ Naber and Molle, 2017).

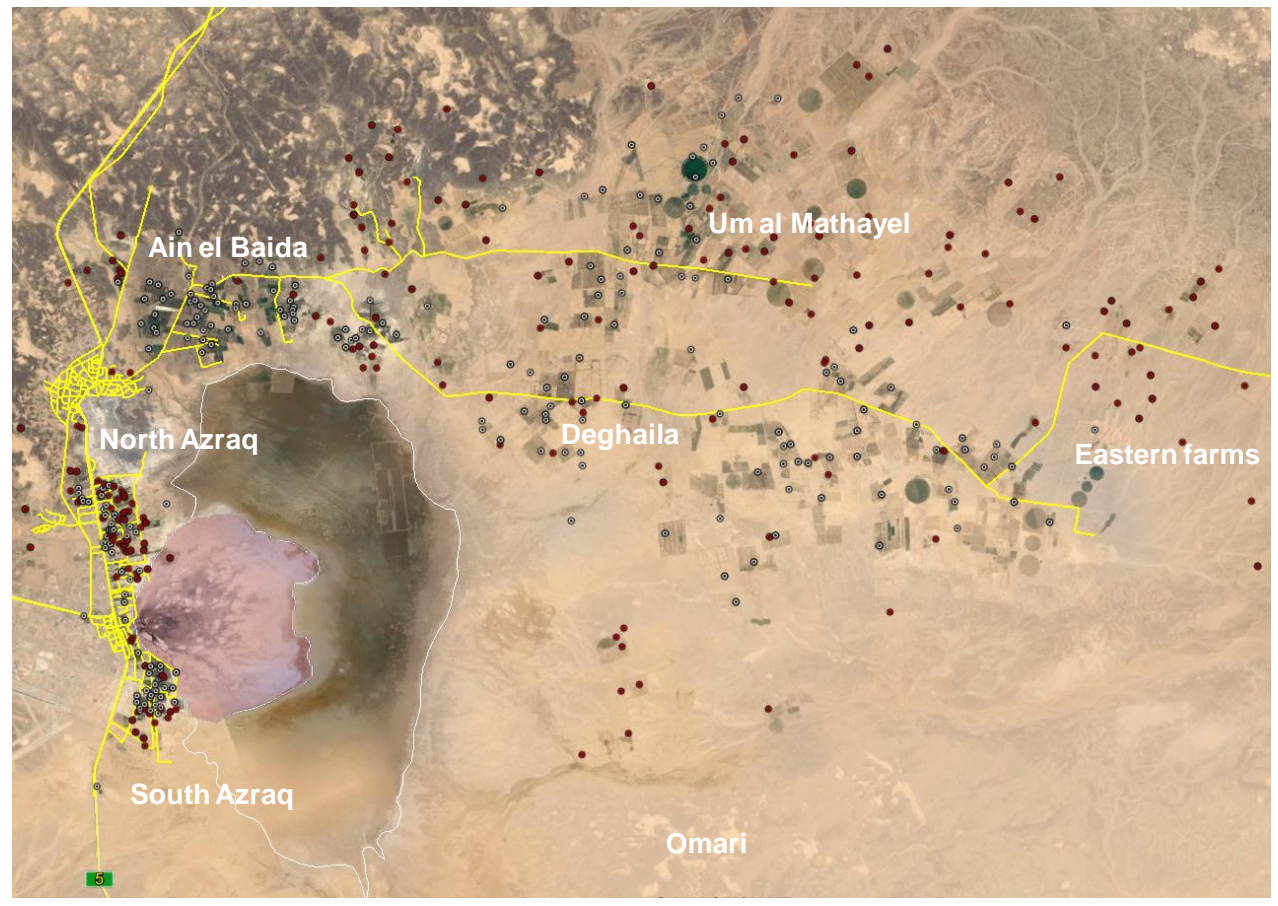

Figure 7-2. Azraq district and roads

This study is based on both written and oral material. Historical data have been gathered from different governmental agencies to study the evolution of the cultivated area, cropping patterns, number of wells and water consumption, and all the available literature on agriculture in the highlands has been collected and mobilized. Empirical data was collected during fieldwork conducted between 2013 and 2015 in both Azraq and Mafraq areas. We 
randomly selected small farms owned by locals as well as farms owned by investors (a few farmers having abandoned their farms were also interviewed for complementary information) with the help of a community organizer knowledgeable of the area. The questionnaires included aspects regarding land status, water status, cropping patterns, production, water and energy sources and consumption, animal breeding, farm revenue and future perspectives on Azraq, solutions, challenges and opportunities. 54 farmers were interviewed in Azraq region and 26 in Mafraq.

Several methodologies can be used to derive farm typologies from a sample of farm-based data (either structural, performative, or related to strategies), including Principal Components Analysis, Multiple Factorial Analysis or Cluster Analysis, or from participatory or expert ranking (Righi et al., 2011; Alvarez et al., 2014; Goswami et al., 2014). Following Demilcamps (2010), we have chosen a farm typology mostly based on cropping patterns and farm size, which somehow also reflects farmers' strategies, as will be shown. It proved difficult to resort to more sophisticated approaches because of the limitations in data acquisition. These limitations included economic data often non-disaggregated by crop (e.g. pumping, fertilizer or labor costs given for the whole farm), various uncertainties (either because data vary from year to year (e.g. olive tree production), or the farmer did not have a very clear idea of the value (e.g. total cost of agro-chemicals used), wanted to minimize economic benefits or distort some values in order to cover up illegal aspect of his farm (e.g. minimizing water use, the number of wells used, etc), or even did not want to give any information (e.g. water bill paid, yield,...). Whenever missing or non-credible ( $21 \%$ ), values of water consumption and/or associated water bills were replaced by average values from the literature (see later section), and so did we for the gross margin of three minor crops, for which our sample data was deemed insufficient.

\subsection{Main current farming systems}

\subsubsection{Cropping patterns and cultivated area}

Modern groundwater-based agriculture was developed in the 1970s based on the introduction of diesel engines and modern irrigation techniques such as drip and sprinkler irrigation systems (MWI, 2013a, 2013b), agricultural know-how tested in the Jordan valley, well-drilling techniques, subsidized energy costs, an environment free of diseases, cheap land and easy access to quality water (IUCN, 2007; Venot and Molle, 2008; ISSP, 2014). All these factors helped make agriculture a prime investment option in Azraq.

The main crops found in Azraq, according to official data for 2010 from the Ministry of Agriculture, are: olives (80\%), vegetables (9\%), alfalfa (4\%) and stone fruit tree and date palms (7\%). The cropping patterns found during the field work in our farm sample were similar, with olive as the dominant crop (80\%), but with a drop of vegetables (2\%) and a hike in alfalfa (11\%). In Mafraq we found that olive only made up $17 \%$ of the total, with $62 \%$ devoted to fruit trees, $4 \%$ to grape, and $17 \%$ to vegetables. Comparisons with Demilcamps' (2010) data for 2009 indicate a shift of 20 points from vegetables to fruit trees which may partly be a sample issue but also reflects an identified trend towards more profitable and less burdensome fruit tree cultivation.

Olive dominates: it is adapted to local conditions but also corresponds to low-cost landoccupation strategies, with few supervision and labor requirements. According to the survey, many farmers are willing to change their cropping pattern and switch to alfalfa production. 


\section{Chapter 7}

However alfalfa requires larger amounts of water and is often associated with unknown illegal wells (and land), for which farmers do not pay water bills. Each of the ten successive harvests yields around $500 \mathrm{JD} / \mathrm{du}$ in revenue (1JD=1.41 \$US). This is a thirsty crop clearly not suitable to Azraq conditions but its market has boomed and made it attractive. The cultivation of vegetables is the second option for farmers but they also consume substantial volumes of water in a short period of time, impacting the water table locally, and face uncertain market prices. Palm trees have been promoted by the MoA in the 2000s and MoA's statistics point to a net profit of $590 \mathrm{JD} / \mathrm{du}$.

In Mafraq, climatic and soil conditions are much more favorable and $90 \%$ of the farms have legal land titles and licensed wells: although the water table is much lower and wells have to be drilled down to $350 \mathrm{~m}$ or more, secure land tenure conditions promote investments and the cultivation of fruit trees. Mafraq is the main producer of fruits in Jordan, including 300,000 t of stone fruit (apricots, flat apricots, peach and nectarines). Only (5\%) of its production is sold internally while the rest is exported to Syria, Iraq and the Gulf by truck. Vegetable production responds to market demand, with a current growth due to the demand of Syrian refugee camps.

With regard to irrigation techniques, drip irrigation was found in 2010 on two thirds of the fields in Mafraq, with the remaining third under micro-sprinkler (virojet) (Demilcamps, 2010). In Azraq, surface irrigation largely disappeared in the 2000 s and was confined to $18 \%$ of the area, along with micro-sprinkler (41\%), drip (20\%), open tubes (8\%), sprinklers $(6 \%)$ and central pivot (7\%). In our sample sprinkler systems have expanded slightly with alfalfa, and surface irrigation remains at $6 \%$ of the area in Azraq.

\subsubsection{Farm typologies}

Five main types of farms were defined in Azraq (Table 7-1). Olive was the dominant crop in all types of farms but one ( 3 farms cultivating only alfalfa). Professional olive tree farmers partly diversified into alfalfa, grape or fruit trees. In addition, in our Azraq sample we found two types of farms with a single occurrence that we kept as a secondary category because of what they stood for: one large 1200 du olive farm well illustrated land occupation strategies through extensive olive farming into the northern (basaltic) part of Azraq. A vegetable-only farm illustrated a case common in Zarqa area. Because some new distant and/or illegal areas were unknown to us, it is possible that our sample in Azraq was slightly biased towards older and legal farms.

Farm budgets were estimated without taking into consideration the initial investment cost because it proved difficult to assess it accurately. Gross margins were calculated based on farm production with no financial and other fixed costs considered. The amount of the water fee paid was problematic: out of the 80 farmers, only 39 were willing/able to indicate the amount of their water bills (some showed us their bills, other gave rounded-up values, with a possible bias towards understatement $\left.{ }^{20}\right)$. In addition to the factors mentioned earlier, results within a given category varied significantly according to water salinity, fluctuating yields

\footnotetext{
${ }^{20}$ Some of these values were considered too low, that is, under $400 \mathrm{~m}^{3} / \mathrm{du}$, probably on account of an intent to underplay the amount of water use. In such cases we used average values and in 3 instances we could re-establish the correct amount based on the stated water bill amount. In Table 7-1 we provide gross margins, calculated assuming that water bills are paid, as well as -between parentheses- the values obtained for stated payments.
} 
(typically for olive), the level of intensification (e.g. the spacing of olive trees ranges from $5 \mathrm{~m}$ $\times 5 \mathrm{~m}$ to $10 \mathrm{~m} \times 10 \mathrm{~m}$ ), the type of energy used, different proportions in the crop mix (in the case of mixed crops, such as olive + alfalfa), and whether trees are small or already producing (for small trees we decided to consider average production and gross margin values of mature trees, to avoid transient distortions and allow for consistent comparisons between farm data). Production for gifts or self-consumption has been valued at market price, but not family labor.

Table 7-1. Details on Azraq farm typology (5 main categories only)

\begin{tabular}{|l|l|l|l|l|l|}
\hline & $\begin{array}{l}\text { Small olive } \\
\text { tree farm }+\end{array}$ & $\begin{array}{l}\text { Small } \\
\text { professional } \\
\text { alfalfa farm }\end{array}$ & $\begin{array}{l}\text { Professional } \\
\text { olive tree } \\
\text { farm }\end{array}$ & $\begin{array}{l}\text { Professional } \\
\text { olive tree with } \\
\text { alfalfa farm }\end{array}$ & $\begin{array}{l}\text { Professional } \\
\text { olive tree with } \\
\text { grape farm }\end{array}$ \\
\hline Number of farms & 16 & 3 & 10 & 11 & 9 \\
\hline Average size $(\mathrm{du})$ & 23 & 45 & 253 & 249 & 142 \\
\hline $\begin{array}{l}\text { Water } \\
\text { consumption } \\
\left(\mathrm{m}^{3} / \mathrm{du} / \mathrm{yr}\right)\end{array}$ & 1287 & 1065 & 1015 & 852 & 947 \\
\hline $\begin{array}{l}\text { Gross margin } \\
(\mathrm{JD} / \mathrm{du} / \mathrm{yr})\end{array}$ & $223(234)$ & $168(195)$ & $-18(10)$ & $50(74)$ & $176(195)$ \\
\hline
\end{tabular}

Table 7-1 confirms that the average income from professional olive farms is close to nil. This stands for a mix of farms that are either run at a (slight) deficit but for which cultivation is speculative or a side hobby, farms affected by salinity with low production, or more professional farms with a reasonable income. Alfalfa and grape are cash crops boosted by good market opportunities that raise the overall income when associated with olive trees. 'Small olive tree farms+' are small farms which a higher average income on account of the fact that they rely on family labor, have electricity and relatively shallow aquifer (near Azraq), and partly diversify into grape, date or pomegranate. 'Single farm' categories showed a profit of $92 \mathrm{JD} / \mathrm{du}$ for the extensive olive farm and $338 \mathrm{JD} / \mathrm{du}$ for the vegetable farm.

The farm typology for Mafraq (Table 7-2) was defined mainly based on cropping patterns since (intensive) management practices are similar and both the well and the land are legal. All farm types are found to be highly profitable. Farmers engaging in cultivation in Mafraq need a lot of capital for land and wells (whether bought or rented), as well as labor. Since all but one well in our sample are legal, the high cost of pumping is compensated by the generous free block tariff (more on this later). Both farm level water consumption and gross margins are of the same order of magnitude across farm types -roughly between 1100 and $2000 \mathrm{JD} / \mathrm{du} / \mathrm{yr}$ for the latter- but vegetable farms, or farms with fruit trees associated with olive trees, have lower margins than stone fruit farms (whether associated with grape or not). 


\section{Chapter 7}

Table 7-2. Farm typology in Mafraq

\begin{tabular}{|l|l|l|l|l|l|}
\hline & $\begin{array}{l}\text { Stone fruit } \\
\text { tree farm } \\
\text { with olives }\end{array}$ & $\begin{array}{l}\text { Stone fruit tree } \\
\text { farm with olives } \\
\text { and grape }\end{array}$ & $\begin{array}{l}\text { Stone fruit } \\
\text { tree farm } \\
\text { with grape }\end{array}$ & $\begin{array}{l}\text { Stone fruit } \\
\text { tree farm }\end{array}$ & $\begin{array}{l}\text { Vegetables } \\
\text { farm }\end{array}$ \\
\hline Number of farms & 5 & 6 & 5 & 7 & 3 \\
\hline Average size $(\mathrm{du})$ & 1220 & 691 & 568 & 338 & 283 \\
\hline $\begin{array}{l}\text { Water consumption } \\
\left(\mathrm{m}^{3} / \mathrm{du} / \mathrm{yr}\right)\end{array}$ & 1007 & 906 & 1330 & 1068 & 823 \\
\hline $\begin{array}{l}\text { Gross margin } \\
(\mathrm{JD} / \mathrm{du} / \mathrm{yr})\end{array}$ & 1296 & 1123 & 1963 & 1994 & 1338 \\
\hline
\end{tabular}

Although we did not systematically evaluate the investment cost of the farms (some are over 40 years old and have undergone several transformations), it is interesting to compare these economic gross margins (roughly $150 \mathrm{JD} / \mathrm{du}$ and $1500 \mathrm{JD} / \mathrm{du}$ for Azraq and Mafraq respectively) with typical investment costs. Investments in Mafraq are more costly than in Azraq in absolute value (higher well depth), typically over half a million JD for a farm of 200 $\mathrm{du}(2500 \mathrm{JD} / \mathrm{du} \text { of land }+50,000 \mathrm{JD} / \text { well and pump }+120 \mathrm{JD} / \mathrm{du} \text { for the irrigation system })^{21}$. Despite such high investments, the returns of agriculture in Mafraq ensure that investments are recouped after 2-3 years of nonproductive installation phase and 2-3 years of production (depending on the time to maturity). A similar farm in Azraq would pay itself after and order of magnitude of 20-30 years, but it all depends on the price of land and whether water is paid.

\subsubsection{Water productivity}

As indicated above, data on water use are often dubious. In order to calculate water productivity it may appear more sensible to use agronomic data on theoretical crop water requirements. This also has the merit to consider consumptive use and not gross abstraction values (which leave the question of what happens to return flows open). We have used the water consumptions values considered by Fitch (2001) and Demilcamps (2010) to fill in water consumption values where data was lacking (or was clearly inconsistent): $790 \mathrm{~m}^{3} / \mathrm{du}$ for pomegranate and olive, 1430 for alfalfa, 1040 for grape, 1045 for fruit trees and 600 for vegetables.

Interestingly, alfalfa, often branded as illegal or unacceptable in such an arid environment because of its high water consumption, appears to have high water productivity. This makes it desirable from the economic point of view that is invariably put forward by donors or the government as a decisive criteria to govern crop selection... Just like with the shift from olive to fruit trees, which have higher water consumption, policy objectives to raise water productivity, whether through higher water prices or otherwise, have the potential to increase water consumption.

\footnotetext{
21 In 2010, a 150 du farm in Azraq cost 70,000 JD for the land and the well and 30,000 JD for the plantation and infrastructure (Demilcamps, 2010). Fitch (2001) computed investments in tree farms in Zarqa basin in 2001 at 1016 JD/du (or $1750 \mathrm{JD}$ in actualized value), and around half of this value for vegetable farms.
} 
At the farm level, water productivity (gross margin/water consumed) in Mafraq is five to ten times higher than in Azraq, despite higher running costs, reflecting the large differences in crop profitability (Figure 7-3). These values of water productivity can be compared with values in other sectors. The recent National Water Strategy (MWI, 2015) points to returns to water of $0.36,25$ and $40 \mathrm{JD} / \mathrm{m}^{3}$ for agriculture, tourism and industry respectively. (For comparison purposes, the average price of domestic water in Amman is around $0.14 \mathrm{JD} / \mathrm{m}^{3}$ ). As a result, it is understandable that the government's pressure on farming is chiefly exerted on Azraq, which is considered as a priority groundwater area for domestic supply.

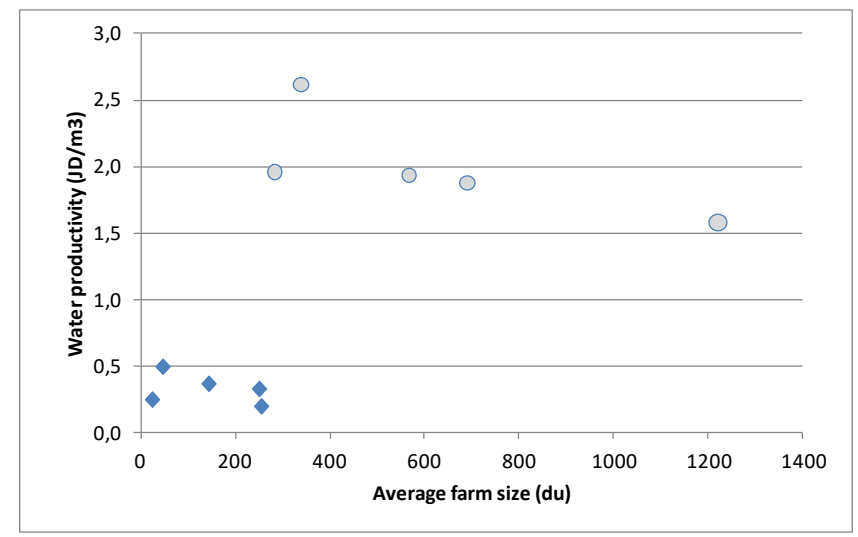

Figure 7-3. Water productivity according to farm typology in Azraq and Mafraq

\subsection{Production factors and trends in profitability}

This section explores in more detail the costs, constraints, and trends associated with the main production factors, as a basis for the analysis of the future of agriculture in Azraq addressed in the subsequent section.

\subsubsection{Labor}

The question of labor availability naturally comes to mind in a remote place such as Azraq, where most farms are isolated and/or far from the city (less so in Mafraq, which is better connected). Two types of labor were found in Azraq basin: permanent workers, who stay in the farm 24/7 and usually come from Egypt or Yemen; temporary labor, brought seasonally during the cultivation and harvesting seasons according to farm needs, most often from villages in the rainfed area, or Syrian refugees.

In order to hire foreign workers for farming, a labor permit needs to be issued by the Ministry of Labor with approval from the Ministry of Agriculture. The labor market is de facto (though unofficially) controlled by labor brokers, with whom farmers prefer to deal rather than going through the long procedure of applying for the official documents and permits themselves. Brokers can sell and buy labor licenses, facilitate the travel of workers from abroad, but also provide farmers with seasonal daily workers, taking a commission in return (typically between 0.5 and $10 \mathrm{JD} /$ person/day). 


\section{Chapter 7}

Sustaining permanent workers has become costlier and more difficult in Azraq, as some farmers have faced problems with permanent workers 'fleeing'. These permanent workers stay at the farm for a short period of time then migrate to cities like Amman without informing the farmer: the monthly salary a worker is 300-350 JD in Azraq, against 750 JD in the construction sector in Amman. But this transfer is sometimes also planned and organized. Some farmers declare larger farming areas in order to get more permits and have surplus labor which can be transferred to the construction sector, a process for which middlemen will pay between 300 and 800 JD to the farmer for ceding one of 'his' workers.

By law farmers had the right to hire one worker for each 10 dunum cultivated. This rule was overly generous and this 'right' has now been reduced to one worker for each $50 \mathrm{du}$. A new law has also been passed to disallow the granting of work permits to farms with unregistered wells. In addition, only farms with legal land deeds can obtain labor permits. Although the Ministry of Agriculture establishes the number of workers per farm according to the cultivated area, in many cases no one from the ministry goes to the field to check the actual cultivated area. The benefit drawn from labor permits also explains the incentives to bribing that come with this process. Farmers without land deeds resort to the services of brokers to hire permanent workers.

By contrast, the availability of daily-wage labor has increased due to the Syrian crisis. Syrian refugees now work in Mafraq and Azraq, notably in the harvesting of olive, at a low wage of $1 \mathrm{JD} / \mathrm{hr}$, which can be compared with a daily wage of 15 JD a few years back.

\subsubsection{Land}

Azraq became an attractive place to invest in agriculture due to cheap and easy access to land and water. However, uncertainty surrounding land ownership remains and affects agriculture investments. From a land tenure point of view, five types of land are cultivated in Azraq: 1) land owned legally with an official land title; and 2) land directly settled, used and claimed by local Bedouins; 3) land informally 'bought' from local Bedouins who claim customary ownership of the land and have ceded it after issuing a 'hijjeh' to the buyer (unofficial document signed by two witnesses establishing the cession); 4) state land occupied and reclaimed and/or rented from the state; 5 ) land rented (often with a well) from a legal owner or a local Bedouin. Investors with a real intent to engage in intensive agriculture generally prefer to buy land legally, thus avoiding uncertainty and risking their investments. Investors attracted by speculation or by the prospect of having their land later legalized and transformed into a valuable asset may buy land through 'hijjeh' (at a much lower price), or even occupy state land.

Whether productive or speculative in Azraq, or highly intensive and professional in Mafraq, irrigated agriculture has generated windfall benefits which have fueled a boom in the land market in the 1990s and 2000s, with land prices skyrocketing (Al Naber and Molle, 2016). In Mafraq, one dunum of land which was sold at 30 JD in 1995 now reaches 1000 JD. In Azraq most recent prices range between 2000 and $4000 \mathrm{JD} / \mathrm{du}$, while some investors recall that in the $70 \mathrm{~s}$ land in this area could be obtained for $1 \mathrm{JD} / \mathrm{du}$... The price of land varies substantially depending on its tenure status, but also whether the land plot includes a well or not, whether the well is legal or not, its discharge, and water quality, and whether the land plot has access to the electricity grid. 
The cash-generating reclamation process relies on the possibility/likelihood of reclaimed land being legalized. This can be done through a process of regularization (or settlement, taswiye) which the government may decide from time to time in order to deal with uncontrolled widespread land occupation, or through the 'delegation' of state land (tafwid), ruled by Law No. 53 of 1977 (Al Naber and Molle, 2016). In practice people start (tree) cultivation based on an illegal well, declare it to the Ministry of Agriculture and then go to DLS to ask for the land to be leased to them. After a minimum of five years of renting, the land can be legally registered under the beneficiary's name (who will however not be able to sell the land during a subsequent period of ten years). De facto privatization of state/tribal land through these mechanisms has now by and large been stalled. The state has become increasingly reluctant to pursue tafwid and taswiye because opening the land Pandora Box proved to generate endless claims and severe conflicts, and also because not legalizing land prevents the legalization of wells and therefore contributes to constraining expansion of groundwater use (Al Naber and Molle, 2016).

It was found that 12 farms out of 54 in our Azraq sample were still illegal with regard to land and 16 with regard to the well(s). In Mafraq the situation is the opposite, with both water and land used in a legal way in all but one case, on account of an earlier and more comprehensive land privatization process.

There is also a poorly studied trend towards renting land and/or wells. Land is generally rented by vegetable growers, who may shift from one location to the other on a yearly basis in order to avoid soil contamination problems. As one farmer indicated, "I can buy land but it is not easy to register it in the DLS and I don't want to deal with hijjeh and illegality, so I go to Azraq and rent a land from farmer for a period of 1 or two years". Renting 100 du with a well costs around 10-12,000 JD, which can be compared with 70-80,000 JD for purchasing a land with hijjeh (only), and 200-250,000 JD for a plot with an official property title. Ramirez et al. (2007) found that in Mafraq 18\% of the farmers were renting a well in 2006.

\subsubsection{Water/energy}

Accessing water has three components: the initial investment in a well/pump/irrigation system; the energy costs of operating the pump; and the payment of water bills to the Water Authority of Jordan (WAJ). The drilling and installation of the well represent a large portion of a farm's initial capital cost. The average cost for drilling a well ranges between 35 and 50 $\mathrm{JD} / \mathrm{m}$, and twice that amount if the well is illegal, or $120 \mathrm{JD} / \mathrm{m}$ including the drilling costs, pipes (from 40 to $70 \mathrm{JD} / \mathrm{m}$ according to the diameter) and casing (but without the pump). The cost of submersible pumps used in Azraq varies depending on its power and discharge, ranging between 6,000 JD for a $30 \mathrm{~kW}$ pump to more than 20,000 JD for a $140 \mathrm{~kW}$ pump. In Azraq, farmers can use small pumps with discharges starting from $30 \mathrm{~m}^{3} /$ hour, while in Mafraq farmers use pumps with discharges reaching $300 \mathrm{~m}^{3} /$ hour.

Energy costs are one of the main constraints in agriculture in Azraq and Mafraq. These costs vary according to the area $-0.015 \mathrm{JD} / \mathrm{m}^{3}$ in Azraq against 0.136 in Mafraq for electric pumps - and reflect in particular well depth and soil transmissivity. Most legal farms are connected to the electricity grid and pay a tariff of $0.06 \mathrm{JD} / \mathrm{KWh}$. Illegal farms not connected to the grid rely either on diesel (but at a cost of $0.12 \mathrm{JD} / \mathrm{m}^{3}$ in Azraq) or on solar energy. Farms in Mafraq are all connected to the grid (it would be too expensive to use diesel considering the depths 


\section{Chapter 7}

at which groundwater is pumped). Farmers renting wells must pay for water, with an additional JD 0.18 per $\mathrm{m}^{3}$ observed in Mafraq in 2006 by Ramirez et al. (2007).

On top of operation and maintenance costs farmers must pay a fee to WAJ, as specified in the 2002 Water bylaw (and its 2004 amendment) (see Mesnil and Habjouka, 2012; Al Naber and Molle, in press). Licensed wells have been granted a generous free block of 150,000 $\mathrm{m}^{3}$ and a cheap price until 200,000 $\mathrm{m}^{3}$ (Table 7-3), while wells with permits ${ }^{22}$ in Azraq got a much less favorable treatment (Table 7-4), and illegal wells have no free block (Table 7-5). Pumping costs are much higher than water costs, and if drip irrigation is adopted to reduce water consumption it is to reduce the former rather than the latter. Although water tariffs are effective since 2003, few farmers paid their water bills until 2010 (in Mafraq in 2006 only $25 \%$ of farmers were doing so, according to Ramirez et al., 2007). Bills with arrears were sent again in 2010 and various mechanisms to force payment by farmers were gradually put in place ${ }^{23}$; pressure on illegal wells was increased through a dramatic increase in tariff in 2014 (Table 7-5). The impact of these measures is dealt with in section 5.

Table 7-3. Tariff for licensed wells all over Jordan (Bylaw 85-2002)(1 JD = 1000 fils)

\begin{tabular}{|l|c|c|}
\hline Quantity of water & $\begin{array}{c}\text { Water price } \\
\text { (amend. 2004) }\end{array}$ & $\begin{array}{c}\text { Water price } \\
\text { (draft 2010) }\end{array}$ \\
\hline $0-50,000 \mathrm{~m}^{3}$ & Free & Free \\
\hline $50,000-150,000 \mathrm{~m}^{3}$ & Free & 10 \\
\hline $150,000-200,000 \mathrm{~m}^{3}$ & $5 \mathrm{fils} / \mathrm{m}^{3}$ & 10 \\
\hline More than $200,000 \mathrm{~m}^{3}$ & $60 \mathrm{fils} / \mathrm{m}^{3}$ & 100 \\
\hline
\end{tabular}

Table 7-4. Water tariff for wells with permits in Azraq area (2002 Bylaw and amendments)

\begin{tabular}{|l|c|c|c|c|}
\hline 2003 to 2005 and after 2010 & \multicolumn{2}{|l|}{ Between 2005 and 2010 } & Draft 2010 \\
\hline Quantity of water & $\begin{array}{c}\text { Water price } \\
\text { (2003/4) }\end{array}$ & Quantity of water & $\begin{array}{c}\text { Water price } \\
\text { (2012) }\end{array}$ & $\begin{array}{c}\text { Permitted } \\
\text { amount 50K }\end{array}$ \\
\hline 0 to permitted amount* & Free & $\begin{array}{c}\text { 0 to permitted } \\
\text { amount }\end{array}$ & Free & Free \\
\hline $\begin{array}{l}\text { Permitted amount to } \\
100,000 \mathrm{~m}^{3}\end{array}$ & 20 & $\begin{array}{c}\text { Beyond permitted } \\
\text { amount }\end{array}$ & 60 & 20 \\
\hline More than $100000 \mathrm{~m}^{3}$ & 60 & & & 100 \\
\hline
\end{tabular}

* $50,000 \mathrm{~m}^{3}$ or $250 \mathrm{~m}^{3} / \mathrm{du}$ for a farm smaller than $200 \mathrm{du}$

\footnotetext{
22 Wells drilled before 2002 (later extended to 2005) and without licenses were given temporary permits with a small free block in Azraq. (In the rest of the kingdom wells with permits are treated as licensed wells.) Those who have their land status regularized can later have those permits transformed into licenses.

${ }^{23}$ Negotiations (and realism), however, led to a wholesale reduction of these arrears to $30 \%$ of their value, according to one MWI official.
} 
Table 7-5. Water tariff (fils/m3) for illegal wells as amended in 2003 and 2014 (Bylaw 852002)

\begin{tabular}{|l|c|c|l|c|}
\hline & 2003 & $\begin{array}{c}2010 \\
\text { (draft) }\end{array}$ & \multicolumn{2}{|c|}{2014} \\
\hline Quantity of water & \multicolumn{2}{|c|}{ Water price } & Quantity of water & Water price \\
\hline $0-100,000 \mathrm{~m}^{3}$ & 25 & 50 & $0-10,000 \mathrm{~m}^{3}$ & 150 \\
\hline $100,000-150,000 \mathrm{~m}^{3}$ & 30 & 70 & $10,000-30,000 \mathrm{~m}^{3}$ & 250 \\
\hline $150,000-200,000 \mathrm{~m}^{3}$ & 35 & 100 & More than $30,000 \mathrm{~m}^{3}$ & 500 \\
\hline More than $200,000 \mathrm{~m}^{3}$ & 70 & 100 & & \\
\hline
\end{tabular}

\subsubsection{Trends in production costs and profitability}

Examining the patterns of production costs sheds light on main production constraints. The distribution of production costs in Azraq and Mafraq (Table 7-6) first evidences differences that reflect contrasts in terms of pumping costs and crops grown. The types of crops grown in Mafraq also require more intensive labor (fruit picking, tree care, etc.) than olive trees. Average total costs in Azraq are 192 JD/du/y, against 335 in Mafraq (74\% higher).

Table 7-6. Production costs in Azraq and Mafraq, according to farm type

\begin{tabular}{|c|c|c|c|c|c|c|}
\hline \multicolumn{4}{|l|}{ Farm type } & \multicolumn{3}{|l|}{ Costs } \\
\hline & $\begin{array}{l}\text { Av. Farm } \\
\text { area (du) }\end{array}$ & $\begin{array}{l}\text { Total costs } \\
\text { JD/du/yr }\end{array}$ & Water \% & Energy \% & Labor \% & Input \% \\
\hline Azraq & 146 & 191 & 3 & 43 & 31 & 23 \\
\hline Small olive tree+ & 23 & 141 & 8 & 17 & 56 & 18 \\
\hline Small professional alfalfa & 45 & 224 & 0 & 21 & 78 & 0 \\
\hline Large professional olive & 253 & 219 & 0 & 38 & 34 & 28 \\
\hline $\begin{array}{l}\text { Professional farm, with } \\
\text { olive and grape }\end{array}$ & 249 & 207 & 4 & 51 & 24 & 21 \\
\hline $\begin{array}{l}\text { Professional farm with } \\
\text { olive and alfalfa }\end{array}$ & 142 & 112 & 4 & 40 & 34 & 21 \\
\hline Mafraq & 627 & 334 & 6 & 43 & 21 & 30 \\
\hline Stone fruit tree and olive & 1220 & 241 & 5 & 53 & 11 & 31 \\
\hline $\begin{array}{l}\text { Stone fruit tree, olive and } \\
\text { grape }\end{array}$ & 691 & 282 & 7 & 54 & 14 & 25 \\
\hline Stone fruit tree and grape & 568 & 435 & 11 & 32 & 18 & 41 \\
\hline Stone fruit tree & 338 & 507 & 5 & 30 & 37 & 28 \\
\hline Vegetable farm & 283 & 434 & 1 & 43 & 38 & 18 \\
\hline
\end{tabular}

In both areas, energy represents the major portion of costs $-43 \%$ on average in both Azraq and Mafraq- followed by labor in Azraq (31\%) and input in Mafraq (30\%). One clear conclusion from farm-level data on Azraq is that diesel (pumping) costs are becoming prohibitive, which makes the control of connections to the grid (now only possible for legalized lands) a possible policy instrument for the government. Water is the cheapest input 


\section{Chapter 7}

in both locations (between 0 and 11\%, with 3\% in Azraq and 6\% in Mafraq on average). This reflects the low tariffs for legal wells but also that a part of the water abstracted escapes monitoring and taxation, and -possibly- the intent of some interviewees to distort reality.

Energy for pumping water made up 15\% of total electricity consumption in Jordan in 2010 (JHK, 2011), showing the magnitude of its impact on national expenditures. With the approval of the renewable energy policy in Parliament in 2012, markets opened up to import of solar technology. As a result, around 10 farms in Azraq were reported to use it, especially the illegal farms formerly using diesel as a source of energy. In Mafraq, farmers are also thinking to convert to this type of energy as it is more sustainable and cost-effective in the long run. One farmer in Azraq was reported to have imported 96 panels from China at a cost of 30,000 JD and to be able to irrigate 400 du with one well $(75 \mathrm{JD} / \mathrm{du})$, which is less than the annual electricity cost for diesel $(120 \mathrm{JD} / \mathrm{du})$ and (only) around three times that of electricity $(22 \mathrm{JD} / \mathrm{du})$ !

Farming input prices (fertilizers, pesticides, etc.) are controlled by private companies. During fieldwork interviews farmers were complaining about the high cost of fertilizers and other agrochemicals. Urea price, however, has been quite stable in the past ten years and since Jordan is an exporter of potash and phosphate it is also partly immune to world market price vagaries.

\subsection{Discussion: the future of agriculture in Azraq}

\subsubsection{Drivers and constraints}

Farmers in Azraq pointed to a reduction in productivity and farming profitability since the early 2000s. The loss of productivity after that date is related in part to a decrease in water quality which directly affected crop production, and also to rising costs. As a result, a number of farms have been abandoned and locals have left the area. On the other hand, some small farms in Azraq south are still being cultivated not because profits are being sustained but because this family farming is basically subsistence farming. In line with this, studies by Fitch (2001) and Rosenberg and Peralta (2012) have both painted a bleak future for groundwaterbased agriculture in the highlands because of the growing costs for accessing water, and the anticipated dewatering of the aquifer in some parts. What do the trends identified above point to?

Around the mid-2000s production costs increased, with labor wages rising from $70 \mathrm{JD} / \mathrm{month}$ in 2002 to 180 JD in 2008, and 280 JD/month at present. The presence of Syrian refugees provides abundant available labor for farm activities which drags down the costs of daily wage, but not of permanent workers, who form a separate 'market'. Energy costs have also increased, in particular following the war in Iraq in 2003 (the price of one oil barrel rose from 6 JD to $104 \mathrm{JD}$ ). This not only increases pumping costs but also transportation costs. Of note is the fact that pumping with diesel in Azraq (often in farms distant from the wetland and the grid, and therefore with higher pumping depths and costs) has virtually made crops such as olive unprofitable. With costs around $0.12 \mathrm{JD} / \mathrm{m}^{3}, 8$ times more than with electricity $(0.015)$ and almost as much as electricity in Mafraq $\left(0.142 \mathrm{JD} / \mathrm{m}^{3}\right)$, any massive increase of water prices by the government (and of its determination to enforce them) will have potentially deleterious additional effects. 
But on the other hand, several factors support the idea that highland agriculture can reinvent itself. First Highland farmers have shown innovativeness and responsiveness to opportunities in adapting cropping patterns and introducing fruit trees around 1990, grape in the late 90s, pomegranate and then palm trees in the 2000s, and more recently alfalfa. A move towards highly profitable crops such as fruit trees, a permanence of olive trees maintained by land speculators at a loss, and the planting of salt-resistant crops such as date palm may help sustain agriculture for some time. Second, the political situation in Syria has spurred an increase in cultivated area in order to fill the gap left by the decrease of Syrian production (internally and for export). Economic opportunities have indeed encouraged more investment in groundwater development in frontier regions (even some Syrian nationals have been reported to rent land to grow vegetables). Ramtha area, to the west of Mafraq and bordering Syria, has witnessed fresh illegal drilling met with leniency from the authorities. According to one official, this leniency is partly due to the sensitivity of border areas (development benefits compensate for tougher clamp down on smuggling and border control), and to the recognition that groundwater in this area flows towards Syria and should be exploited. Third, solar energy is proving to be cost-effective and could be a game changer in that in reduces energy costs and frees farmers from the constraint of obtaining an electric connection, boosting illegal expansion at the very moment diesel prices were jeopardizing it.

The question arises as to what is the future of groundwater-based agriculture under current abstraction rates, when one considers increases in salinity, growing pumping costs and those of retrofitting wells and pumps. A study by Rosenberg and Peralta (2012) came up with bleak conclusions and estimated that as much as $79 \%$ of olive and vegetable farming in Azraq might become economically unviable in the next ten years, leaving concerned farmers with the choice of either shifting to higher value crops or quitting farming altogether. Some farmers acknowledge that this process is likely to put a significant number of farmers or investors out of business, with only the 'fittest' surviving, namely those who have the connections, capital and know-how to ever intensify, tap export markets, and shift to solar energy or even desalination of brackish water (as observed in the south of Jordan valley), and -perhapsevade thorough investigations of their well/water use situation... There is some resentment amid local farmers against outsiders who have the capital to continue mining groundwater, or to keep leisure/prestige farms at a loss, while they themselves are displaced.

During the 11 meetings of the Highland Water Forum (a multi-stakeholder platform set up to discuss groundwater issues) held between 2010 and 2013, several ideas were proposed and discussed regarding future options (Demilcamps, 2010; HWF, 2015), including adopting plants tolerant to arid environments and salinity, saving water by different farm practices and technologies, developing income-generating alternative activities such as 'solar farming' or ecotourism, or having the state buying out farms or wells. But these mitigating measures are unlikely to significantly affect on-going trends. The game changer might be government policies, now geared towards toughening and enforcing regulations on illegal wells.

\subsubsection{Water pricing and other groundwater policy measures}

Since 2002, The MWI is trying to increase the control, rule enforcement, and monitoring of water use and consumption in agriculture. It also tries to use the block tariff water pricing of the 2002 bylaw as a tool to both elicit water savings and squeeze illegal farms out of agriculture (Venot and Molle, 2008). An amendment of the 2002 Bylaw was floated in 2010 but was never passed, due to the opposition it raised. The free block for legal wells all over 


\section{Chapter 7}

Jordan was to be reduced from 150,000 to $50,000 \mathrm{~m}^{3}$, but Azraq would keep distinct and higher tariffs for higher blocks. All wells with permits in Azraq would have the same 50,000 $\mathrm{m}^{3}$ free quota, pay 0.02 JD for every $\mathrm{m}^{3}$ until 100,000 $\mathrm{m}^{3}$, and 0.1 JD beyond (see Table 7-3 to Table 7-5). Last, the tariffs for illegal wells would be increased for each block.

In 2013 the Ministry started a campaign to close all unproductive wells as a first step towards closing all illegal wells in the country. In 2014 a bylaw amendment targeted illegal (registered) wells, raising their water tariff table to very high levels (see Table 7-5). Lately in 2015, the free abstraction block in Mafraq was also changed officially from 150,000 to 75,000 $\mathrm{m}^{3} / \mathrm{yr}$ for any well deepened or drilled to replace an old well. Satellite imagery and remote sensing tools are now used to monitor and observe agricultural activities in the basin and to spot farms with inconsistency between the visible crop area and water data.

We can use our sample to estimate the impact of changes in tariffs on the average gross benefit of each farm category. Because of the missing data regarding actual water bills and whether farmers have paid them or not, we take as our baseline a situation where farmers are supposed to pay as per the 2004 tariff table. We then use our sample to consider several scenarios (Si) and evaluate their impact:

- Application of the (aborted) 2010 amendment in Azraq and Mafraq (S1)

- Simulation for Azraq assuming that 1) all wells are given permits [S2], 2) all wells are illegal [S3], 3) all wells are illegal and the 2014 tariff for illegal wells is applied [S4]

- Simulation for Mafraq, where basically all wells are legal, assuming that the free block is $50 \mathrm{~K}$ (like in S1) but the second block $\left(50,000\right.$ to $200,000 \mathrm{~m}^{3}$ ) is charged 60 fils instead of 10 [S5]

Table 7-7 provides the results of these simulations. The impact of S1 is limited in Azraq, where some farms (constrained by a $250 \mathrm{~m}^{3} / \mathrm{du}$ limit) even benefit from the uniform $50 \mathrm{~K}$ free block which improves their situation. In Mafraq, (legal) wells see their water charges almost doubled but because of the limited weight of these costs the impact on gross margins is limited. S2 shows that if all wells in Azraq were given permits ${ }^{24}$ margins would improve slightly and these margin values can be compared with S3 to see the impact of all the wells being legal or not: gross margins do not vary much on account of the fact that current tariffs for illegal and permitted wells differ little. In S4 we apply the new 2014 water tariffs to the wells (now all considered as illegal) and we find that all categories become markedly unprofitable due to a ten-fold increase in water costs, showing that if these tariffs are applied farms with illegal wells will be bankrupt right away. One option for these farms is to reduce the area planted drastically and grow fruit trees. S5 tests a 50K free block, like in S1, but applies a 60 fils price to the second block instead of 10 fils. Water costs are only marginally increased, reflecting the fact that they are mostly made of volumes in the third block that are (already) charged at 100 fils. The conclusion is that Mafraq agriculture is unlikely to be substantially affected by changes in tariffs (that are politically conceivable for legal wells).

\footnotetext{
${ }^{24}$ Very few wells in Azraq (and none in our sample) have licenses like in Mafraq. Around half of the wells have permits and the other half are illegal.
} 
Table 7-7. Average gross margins for different farm categories under several water pricing scenarios

\begin{tabular}{|c|c|c|c|c|c|c|}
\hline \multirow[t]{2}{*}{ Farm type } & & \multicolumn{5}{|c|}{ Gross margin (JD/du/y) } \\
\hline & Baseline & S1 & S2 & S3 & S4 & S5 \\
\hline \multicolumn{7}{|l|}{ Azraq } \\
\hline Small olive tree+ & 223 & 232 & 225 & 214 & -45 & \\
\hline Small professional alfalfa & 168 & 142 & 179 & 168 & -118 & \\
\hline Large professional olive & -18 & -31 & -17 & -23 & -388 & \\
\hline $\begin{array}{l}\text { Prof. farm, with olive and } \\
\text { grape }\end{array}$ & 50 & 30 & 50 & 50 & -331 & \\
\hline $\begin{array}{l}\text { Prof. farm with olive and } \\
\text { alfalfa }\end{array}$ & 176 & 166 & 177 & 174 & -197 & \\
\hline \multicolumn{7}{|l|}{ Mafraq } \\
\hline Stone fruit tree and olive & 1277 & 1258 & & & & 1243 \\
\hline $\begin{array}{l}\text { Stone fruit tree, olive and } \\
\text { grape }\end{array}$ & 1117 & 1092 & & & & 1075 \\
\hline Stone fruit tree and grape & 1951 & 1919 & & & & 1903 \\
\hline Stone fruit tree & 1991 & 1968 & & & & 1946 \\
\hline Vegetable farm & 1331 & 1320 & & & & 1293 \\
\hline Azraq - Total water fees (JD) & 264,456 & 407,471 & 254,377 & 274,405 & 2972,367 & \\
\hline Mafraq - Total water fees (JD) & 596,161 & 1132,309 & & & & 1326,939 \\
\hline
\end{tabular}

\subsection{Conclusions}

In the 1980s Azraq became a hotspot of agricultural development in Jordan, with investors from Amman or abroad capitalizing on cheap land and shallow groundwater. Unabated growth in irrigated areas and groundwater abstraction, however, dried up the springs and the wetland and caused severe draw-downs and deterioration of water quality, with emerging negative effects on farm productivity and profits. The northern part of the basin (Mafraq) stands in sheer contrast with Azraq proper, with legal farms/wells growing high value fruit trees and achieving gross margins of around $1500 \mathrm{JD} / \mathrm{du} / \mathrm{y}$, that is, ten times more than in Azraq in order of magnitude, despite farming costs being $70 \%$ higher than in Azraq.

Farm typologies for Azraq show that a part of olive tree-based agriculture is hardly profitable and corresponds to land occupation/speculation strategies or Sunday-farming investments. Farms with family labor and/or diversification into grape or alfalfa fare better and have gross margins of around 100-200 JD/du. Declining well yields and water quality, together with higher Azraq-specific water tariffs, have spurred adaptation in terms of cropping patterns but also the drilling of illegal (unregistered) and/or deeper wells. Tough measures may well contribute to getting some farms out of business, especially where groundwater is becoming saline, a process that could be speeded up by the offer of compensations (and alternative economic opportunities) by the state. In other words, we observe the adaptive/coping as well as exit strategies observed in other settings, such as Morocco (Berahmani et al., 2012) and India (Shah, 2009). 


\section{Chapter 7}

What is specific to Azraq, however, is the increasingly strong resolve of the government to curb abstraction in order to protect the well field that contributes to urban domestic supply, and also as a consequence of the nation-wide stiffening of groundwater regulations (Al Naber and Molle, 2017). We showed that agriculture in Azraq is vulnerable to the tariffs established for illegal wells in 2014 which -if applied- would kill off farms with such wells. Norms regarding foreign workers permits have been changed, connections to the electricity grid are now conditional upon having a legal land title, and land settlement processes have been stalled, making the constitution of landed assets less likely and investments in land less attractive. Last, escalating energy costs have dented incomes. We showed that these combined indirect pressures through water and energy tariffs and land and labor policies have the potential to rein expansion in and to lead some farm owners to discontinue agriculture.

Such a remarkable achievement, in view of the near worldwide failure of governments in reducing groundwater abstraction (FAO, 2015), is yet to be seen. First, solar energy might turn to be the trump card of illegal expansion at the very moment high diesel costs and state control on connections to the grid were starting to jeopardize it. Second, the most technically efficient growers of cash crops taping export markets or temporary niches such as alfalfa, may emulate the Mafraq model and gradually displace underperforming farms, while still expanding in remote areas. It may also be the case that investors will move on to less regulated (e.g. Ramtha, near the Syrian border) or little exploited (e.g. Jafr basin) areas ${ }^{25}$, merely shifting the problem spatially, as is observed in many countries.

In contrast, Mafraq's hefty farm investments and legal status seem to be immune to policy changes and resilient to foreseeable changes in factor prices or markets. Furthermore, market demand fuelled by the situation in Syria and a growing demand, cheap available daily wage labor (refugees), as well as political considerations, may well act as drivers of further groundwater-based expansion in areas such as Ramtha, running counter to the regulatory efforts deployed. Politics, whether because of regional instability, changes in the Ministry, or the need to keep a (delicate) balance between public objectives and individual claims/demands in a post Arab Spring context, may well decide the course of events

\footnotetext{
${ }^{25}$ Despite poor water and soil quality and its remoteness, Jafr basin has already attracted the interest of the Agrobusiness companies which have been forced to move out of Disi.
} 
CHAPTER EIGHT

Synthesis 



\section{Chapter Eight: Synthesis}

\subsection{Topics of investigation}

The use of groundwater by different sectors (industries, agriculture, municipalities, environment and tourism) has been accelerating in many countries worldwide, as water demand is increasing, and most available surface water is already used (Vrba and van der Gun, 2004; Llamas and Martinez Santos, 2005; Hammani et al., 2009). Consequently, a continuous decline of groundwater levels has been observed in many countries in the past half century (Bajjali and Al-Hadidi, 2005; Gaur et al., 2011; Zhou et al., 2013). The overexploitation of renewable and non-renewable aquifers for both urban use and irrigation frequently results in a reduction of groundwater availability and quality (FAO, 2003; Goode et al., 2013). The use of groundwater for irrigation purposes has a negative effect on groundwater systems as it accelerates aquifer depletion and decreases the availability of water but, on the other hand, has a positive effect for the users as it helps in reducing the poverty of smallholders, provides better food security and improves livelihoods (FAO, 2015).

This study focused on the use of groundwater for irrigation in desert or arid areas of the MENA region, and most specifically Jordan. Groundwater-based agriculture in arid parts of the MENA region has developed and expanded in 1960s-1970s in parallel with technical change in irrigation and well-drilling techniques, but also due to state subsidies supporting this activity (Imache et al., 2010; Aw-Hassan et al., 2014; UNDP, 2013b). In all MENA countries, groundwater has allowed the expansion of irrigation in arid/desert areas, where no rain fed agriculture is possible (Stack, 2009; Adriansen, 2009; Ben Hounet et al., 2011; Manseur, 2017). The expansion of groundwater-based agriculture into desert lands of the MENA region has become a strategy for either individuals or corporate entities or for the governments, in a bid to provide settlement/livelihood opportunities and boost agricultural production and/or exports (Sims, 2015). This development has been associated with a deep concern for the overexploitation of aquifers as water is generally extracted (far) beyond the so-called "safe yield."

Faced with the overexploitation of groundwater resources, MENA countries have tried to control and manage the use of groundwater resources by direct and indirect policy measures (Chapter 2; Chapter 6). Direct policy measures/approaches are implemented by the state and control, allow or prohibit certain activities or behaviors. They control and monitor groundwater use and restrict it through well licenses and permits, sealing wells, banning new well drilling or the deepening of old ones, defining prohibition areas, imposing metering systems, establishing quotas, etc. Indirect measures work as incentives and control well drilling or groundwater abstraction by changing the relative cost of specific production factors or output prices, including block tariff for groundwater use, high water tariff for illegal wells, constraining the granting of labor permits, discontinuing the distribution of state land, raising people's awareness, 'naming and shaming' strategies, etc (Chapter 2; Chapter 6).

Reviewing groundwater policies in the MENA region showed many similarities across countries, such as the establishing of a system of well registration and permits, the possibility to declare specific overexploited areas as conservation or prohibition areas, the adoption of metering or economic tools. Despite such a panoply of tools and the promotion of 'best practices', controlling groundwater abstraction has been found to be almost impossible in 


\section{Chapter 8}

contexts where agriculture users are in high number and spatially scattered (Molle and Closas, 2017).

Desert agriculture, like any agricultural activity, requires land, water, energy, labor, capital and agricultural input. But farming in a desert or arid environment, when water is available, is often associated with a number of specific constraints such as access and distance from markets and settlements, labor shortages, a harsh climatic environment, the need for considerable capital to kick start cultivation, problematic land tenure status, higher energy costs (e.g. no connection to the grid, pumping from deep aquifers, well drilling cost, etc.). In this thesis, the researcher studied and reviewed how these difficulties have been dealt with in Azraq basin and in the case of selected countries of the MENA region.

This thesis investigated the physical, economic and political conditions that undergird the development of desert agriculture in the MENA region, most specifically in the Azraq Basin, Jordan. After a general overview of desert agriculture in some countries of MENA region, we analyzed the conditions that allowed for or encouraged agricultural development in Azraq, studied in more detail the modalities of accessing land and water, and explored its performance and sustainability under different scenarios.

\subsection{Adopted methodology}

The methodology adopted for this research is based on four successive steps (Figure 8-1) which are: defining and studying the general and physical context of the subject, both regarding historical development and the current situation; understanding and analyzing all the interrelated factors that drive the current situation and investigating future evolutions; and concluding with a focus on the lessons learned.

\section{Defining and studying}

\section{Understanding}

\section{Analysing}

\section{Concluding}

Figure 8-1. Adopted methodology

This research rests on the core proposition that desert agriculture faces specific challenges that need to be studied, understood and analyzed to better comprehend its present and future states. The researcher started by studying an extensive literature, reviewing the situation of groundwater use and depletion globally, highlighting groundwater-based 
agriculture in the MENA region and the management options that are usually adopted, and then focusing on desert agriculture. Studying desert agriculture led the researcher to ask herself what are the driving forces fueling this kind of activity in areas that are suffering from water stress, how they are related to each other and to main production factors and their level of accessibility. Therefore, the researcher studied, understood and analyzed in detail the key areas of land, water and other production factors (energy, labor, inputs) in terms of social and policy contexts in selected countries of the MENA region, with a detailed historical study and analysis elaborated for the Azraq basin case study.

Is desert agriculture economically viable? To answer this question the researcher conducted in-depth surveys in agricultural areas of the Azraq basin. Farm typologies were elaborated based on the questionnaire results and the variability in farm gross margins and factor prices highlighted the differences between the two agricultural areas in the basin (Azraq and Mafraq). Different future scenarios were developed for the case study area based on prospective groundwater prices and general considerations on agriculture.

A state-of-the-art review about desert agriculture in the MENA region allowed the researcher to highlight the driving forces behind this activity in selected countries of the MENA region, singling out similarities and specificities. An in-depth case study on desert agriculture in Azraq basin, Jordan, has been carried out. Analysis of driving forces and access to production factors (land accessibility and laws; groundwater policies, measures, tools and incentives; how they are implemented and how users react to them; farm typologies), provided the researcher with a wide view about how this activity is developed by users and managed by the government. The researcher further reflected on the learned lessons from this case study by checking them against the situation of other countries in the region.

During the study the researcher realized that the topic revealed itself to be interconnected with multiple issues. 'Horizontally' the issues of land and water accessibility or policies, as well as that of other production factors, combined in the analysis of farming systems. 'Vertically' groundwater and land policy issues took us to a more intricate web of actors (locals, NGOs, investors, academics, policy-makers, etc) and to political dimensions seemingly lying outside of the investigation. Constrains were faced when sourcing information from a diversity of actors not always willing to provide information, and when reaching out to distant and isolated farms in the field.

\subsection{Answering the research questions}

To improve the understanding of how desert agriculture expanded and intensified in Azraq basin, the thesis addressed one main question as well as five sub-questions. Four subquestions were focused on our study area and in line with the research methodology introduced, while the last question reflects on this thesis' findings and how they relate to the experience in the MENA region countries that are witnessing a growth of desert agriculture. This section concludes on how this thesis answered the research questions addressed.

The main research question of this study is:

- What are the physical, economic and political conditions that drive the development of desert agriculture in Jordan, and most specifically Azraq Basin, and what is the future of this type of agriculture? 


\section{Chapter 8}

The development of desert agriculture is allowed by the combining of different production factors that are illustrated in Figure 8-2. Controlling and managing the development of desert agriculture is very complex and difficult to achieve as the physical, economic and political conditions that determine the level of availability of, and accessibility to, production factors are interconnected and there is not a one to one causal relationship between each of these conditions and their respective effect on desert agriculture. Figure 8-2 presents a summary of the main issues and conditions that control the availability and accessibility of production factors in the development of desert agriculture. The relation between the development of desert agriculture and each production factor is described in more details in the following sub questions.

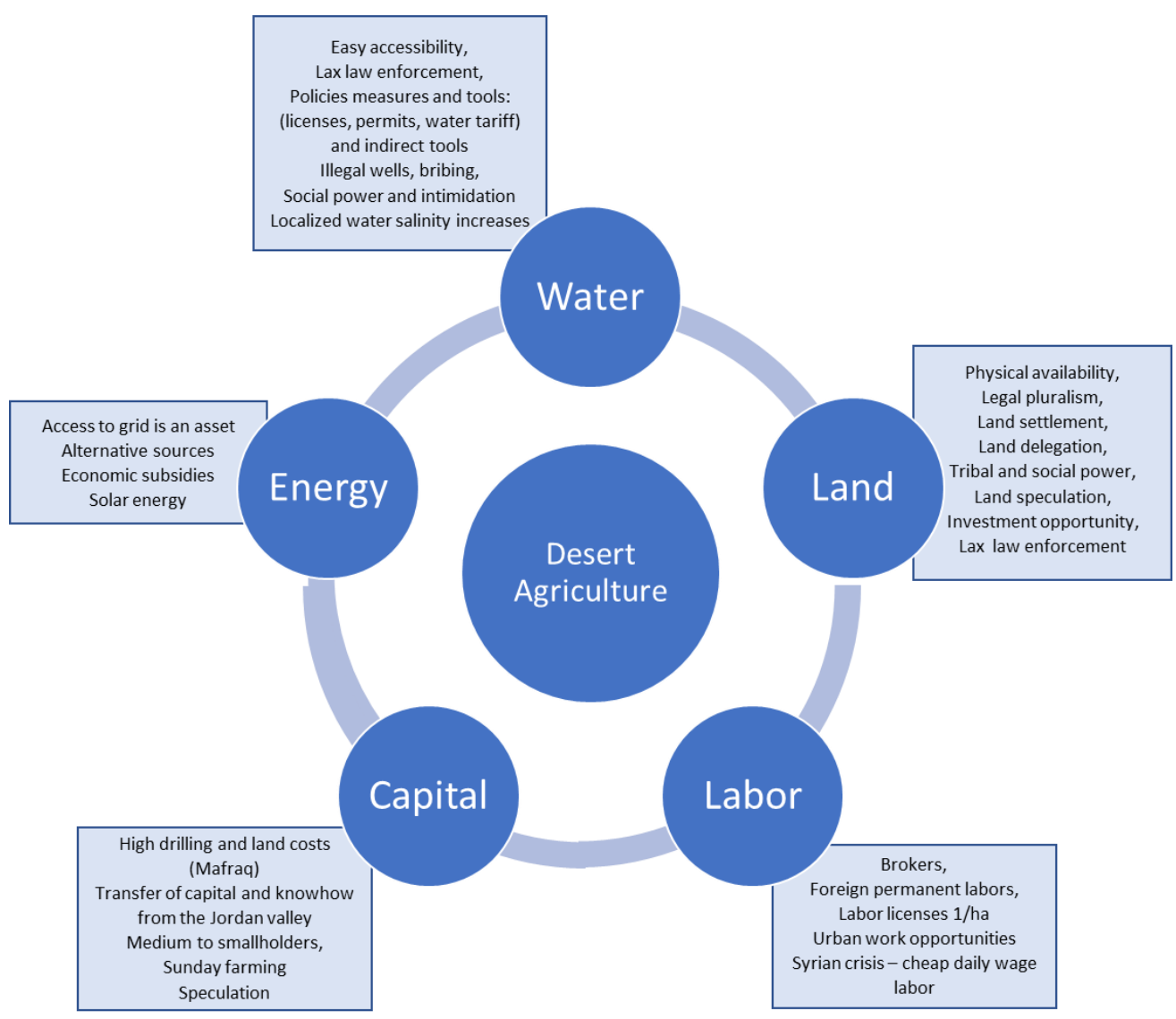

Figure 8-2: Summary of main issues related to each production factor

\section{- What are the driving forces of desert agriculture development in Jordan and the Azraq basin?}

Groundwater-based agriculture in Jordan occurs mainly in part of Amman-Zarqa basin and Azraq basin in the north, and Disi basin in the south. The dependency of agriculture on 
groundwater varies from one basin to the other, since in parts of the highlands of AmmanZarqa basin agriculture can resort to rainfall, surface water or groundwater. In contrast, Disi and Azraq basins are located respectively in the southern and eastern deserts of Jordan where groundwater is the only resource available for irrigation.

The researcher identified the driving forces behind the process of desert agriculture expansion. The relatively easy accessibility to land and groundwater resources were found to be the initial main driving forces of desert agriculture in Azraq basin, Jordan (discussed in detail in the following question), although this accessibility was found to be increasingly problematic (ban on well-drilling, crackdown on illegal wells, privatization of state land discontinued) (Chapter 5 and 6). It was found also that groundwater-based agriculture in Jordan comes with two distinct (but possibly combined) purposes: a) an investment opportunity with a good return on investment; b) land speculation (agriculture is a means to obtain, with time, private ownership of state land) often associated with Sunday Farming (urbanites enjoying the place on weekends). Smallholder farming can be set aside, as it historically developed based on spring water and in parallel with settlements. It is homeconsumption oriented and increasingly residual. Agricultural development in Azraq is fueled by both these individual profit-making strategies and the state (Chapter 5, 6 and 7). Although this is now changing, the state has indirectly facilitated the process through its lax implementation and enforcement of laws (pervasive illegal well drilling and state land occupation, weak monitoring of actual water use, etc) and various types of misplaced economic subsidies (irrigation systems, seedlings, fuel price -before the Gulf War-, soft loan for drilling private wells, etc) (Chapter 5, 6 and 7). Profit-making individual investors, whether locals or outsiders, seize the opportunities available to invest in desert farming, navigating the different constraints attached to each of the production factors.

\section{- How do public policies deal with the resulting over-exploitation and depletion of groundwater resources?}

Faced with extreme water scarcity and a situation where all conventional resources and reuse of treated wastewater are already exploited, the Jordanian government has tried and is still trying to monitor, control and manage groundwater use and illegal expansion of cultivated areas (Chapter 5 and 6). It has implemented a series of regulatory and incentivebased tools concerning groundwater access and use (Chapter 6 ). But because of the systemic interrelationships of water use with land, labor and energy issues - made explicit above - the $\mathrm{MWI}$ has also sought to regulate them indirectly, by supporting changes in the policies and rules governing these sectors (Chapter 6).

The illegal expansion of agriculture area happens normally on state lands (Chapter 5). In order to curb illegality and solve land problems, several mechanisms exist within the Department of Land and Survey to legalize lands by taswiye, tafwid, and royal gift (Chapter 5). Taswiye (Land settlement) generally takes place to legalize de-facto settlements of families on new land, while the tafwid (delegation) is linked to reclamation and agricultural activities on the land. Legalizing land is meant to decrease illegality in agriculture - since wells licenses, labor licenses and connection to the electricity grid cannot be obtained without a legal land deed-, and should help the government control the amount of groundwater abstracted. On the other hand, activating these mechanisms encourage people to extend 


\section{Chapter 8}

their cultivated areas or cultivate new areas illegally, in the hope to legalize them afterward (Chapter 5). Theoretically the government is controlling encroachment on this type of land through its Desert Patrol, whose job is to quell the occupation of state land and to remove illegal farms. But destroying illegal settlements is generally not achievable as this faces violent reaction from locals and generates tensions with tribes (Chapter 5 ).

Groundwater-based agriculture in Jordan was encouraged by the government in the early 1970s through the provision of well licenses and soft loan for drilling private wells (UNPD, 2013b). With the increase in groundwater use, the government passed specific laws and bylaws to regulate well drilling and groundwater abstraction. The use of groundwater is controlled by two main laws (Chapter 6): Water Authority Law no 18 of 1988 and the Groundwater Bylaw 85 of 2002. Through these two laws, the government reiterated earlier measures such as licensing and metering, and introduced other direct and indirect measures and tools to control the abstraction of groundwater. Direct measures include well licensing, establishing annual quotas per well, sealing illegal wells, licensing and monitoring drilling companies and drilling activity, limiting the number of well licenses to one per plot of land, and banning any new well drilling for agriculture (in 1992). Indirect measures include a block tariff pricing system, sharply increasing the water tariff of illegal wells, constraining the granting of labor permits, publishing the names of violators and people with large arrears of water charges in newspapers ('naming and shaming'), publicizing tough actions on the ground in the media, using satellite imagery to estimate and charge water consumption, and improving inter-departmental coordination to force users to pay water bills (Chapter 6).

Chapter 6 described the level of implementation of all these direct and indirect measures in detail and how users adjusted to them. Generally, the application of tools requiring interventions in the field was found to be frustrated by a number of factors: first, the number of WAJ staff and their equipment are insufficient to fulfill the tasks entrusted to them. Second, these field personnel often have social links with the local people they are supposed to control. Third, controlling illegal practices, checking well characteristics, reading meters (with the perspective of associated water fees), or demanding payment requires heavy presence in the field. These factors create a fertile environment for and incentives to bribery. Last, intimidation by local Bedouins, sometimes with a show of weapons, does not encourage field personnel to take risk of enforcing the law when, at the same time, the degree of resolve of higher-level authorities in enforcing it is unclear. Pressure from the top is useful but can also have detrimental effects. Molle et al. (2017a) have evidenced a total disconnect between agricultural statistics, which indicate a doubling of the irrigated area since the beginning of the 1990s, while data for the same period from the MWI show that groundwater abstraction has leveled off at around $250 \mathrm{Mm}^{3} / \mathrm{yr}$. They posit that this disconnect reflects the pressure exerted on staff from both ministries to produce (low) groundwater abstraction numbers and (high) agricultural areas. Using satellite images AlBakri (2015) has shown that substantial expansion of irrigated areas did take place in Azraq and Mafraq areas during the period 1990-2014, with irrigated areas increasing from 17000 and $36000 \mathrm{du}$ in 1990 to 46000 and 134,000 du in the 2013/2014 season for Azraq and Mafraq respectively.

Indirect measures which do not require periodic information from the fields have been more successful. Jordan has implemented a few very original strategies to enforce the law. The first one is the interconnection of public services and registers. Groundwater users who have 
arrears of water bills can now see their request for a new passport, a land transaction, or a marriage certificate turned down, or even be barred from leaving the country. In addition, the biggest defaulters now see their names published in newspapers and on the internet. For example, recently in August 2017, WAJ published in the Official Gazette and online newspapers the names of defaulters who refused to pay their cumulated water bills, and the Authority has promised to take appropriate measures to freeze their assets within 60 days from the date of publication of the declaration in the Official Gazette (Alsaa.net, 2017). This potentially poses a huge challenge - and a threat - to owners of (registered) illegal wells on whom very discouraging water tariffs are being applied (although there is no information on how systematically these measures are implemented).

The Ministry has also consistently and for many years raised the awareness of the seriousness of Jordan's water situation of various segments of the society (Chapter 6; Molle et al., 2017a): users in general, but also members of parliament, judges and even imams in order to enhance citizens' awareness and also to create an environment more likely to accept the implementation of drastic measures.

The political will to tackle Jordan's water crisis manifested by the current minister is probably unparalleled in the MENA region (Closas and Molle, 2016). Yet, if anything, the difficulties experienced in enforcing the policy measures put in place demonstrate the magnitude of the challenge in controlling diffuse groundwater agricultural use, for reasons that are logistical, social and political.

\section{- How do desert agriculture entrepreneurs access the various production factors needed for cultivation in such a specific environment and what particular problems do they face?}

Land: Desert lands before the 1960s were out of sight and had little value. The putting of all desert land under state ownership in 1958, furthering the reforms of the British Mandate, did not arouse much reaction, as the manifestation of state power in desert areas was limited to the Desert Patrol (Fischbach, 2000). Bedouins were using their traditional grazing lands for their herds and land issues or conflicts were largely between tribes (Fischbach, 2000). With the development of irrigation and drilling techniques and the availability of water, the value of these lands changed radically and investors moved in to develop agriculture.

In some cases, like in Mafraq, land had already largely been allotted to local tribes and individually appropriated, with legal land deeds (Chapter 5 and 7). Local owners invested in their own lands or sold it to outsiders (Chapter 5). In Disi, land was apportioned to both local small farmers and four large-scale companies which received long-term leases agreements from the state (Barthelemy et al., 2010). In Azraq, settled Druze and Chechen communities were the first to dig wells close to the wetland to take advantage of the shallow groundwater resource for small gardening agriculture. Local Druze and Bedouins gradually developed some commercial agriculture but also engaged in land brokering (Chapter 5).

But who owns the land? Desert land comes under two categories. State land under the formal ownership of the state treasury, and state land that has not been formally titled and, although also under state property, which can be either transferred to citizens through land settlements projects (this privatization process is called taswiye) or claimed by whoever can prove to have put it to productive use for a number of years (this 'ihya' process is sanctioned 


\section{Chapter 8}

by the Islamic tradition), the plot being 'delegated' to the cultivator through a process called 'tafwid')(Chapter 5). But such legal categories basically negate the customary rights of local Bedouins tribes which are loath to accept dispossession of a resource at the very time it is becoming valuable. As observed in other countries such as Syria or Egypt, Bedouins impose through their social power and sometimes intimidation- a parallel system of access to land, exacting financial benefits from whoever wants to settle and/or invest in land locally (Sims, 2015). They issue a 'hijjeh' (proof) to the prospective investor against payment, which although officially deprived of value will be considered in case of land settlement (Chapter 5).

As a result, from a land tenure point of view, five types of land are cultivated in Azraq: 1) land owned legally with an official land title; 2) land directly settled, used and claimed by local Bedouins; 3) land informally 'bought' from local Bedouins who claim customary ownership of the land and have ceded it after issuing a 'hijjeh' to the buyer; 4) state land occupied and reclaimed and/or rented from the state; 5 ) land rented (often with a well) from a legal owner or a local Bedouin (Chapter 5). Investors with a real intent to engage in intensive agriculture generally either already own the land (Mafraq) or buy it legally from the owner, in order not to put their investment at risk (Chapter 5). But many locals or investors have speculative motives, i.e. they are attracted by the prospect of having their land later legalized through 'taswiye' and transformed into a valuable asset, and may 'buy' land through 'hijjeh' (at a much lower price), or even occupy state land (Chapter 5).

The 'price' of land in the desert generally, and in Azraq in particular, is cheap due to the illegal nature of the 'sale' by Bedouins, and to the fact that land is far away from the city and often deprived of infrastructure. Bedouins issue 'hijjeh' against a payment that typically varies around $5000 \mathrm{JD} / \mathrm{ha}$, or more if it already has a (illegal) well (Chapter 5). Land availability, relatively good access, and not too deep groundwater (between 10 and $70 \mathrm{~m}$ ) compared with Mafraq (around $350 \mathrm{~m}$ ), land settlements that boost the likelihood of land being one day regularized helped make Azraq a prime option to invest in land, irrespective of what type of agriculture is to be conducted and despite the risk.

If taswiye and tafwid processes fuel the demand for land and the associate use of groundwater, what is the government's response in front of this phenomenon that clearly compounds the overexploitation of Azraq aquifer? We have shown that this response is ambiguous and for two reasons (Chapter 5). The first reason is the contradiction between agricultural policy on the one hand, and water conservation policy on the other. While the Ministry of agriculture still aims at maximizing the cropping area and national agricultural production, this intent squarely contradicts the efforts deployed by the Ministry of water and irrigation. Mechanisms to help cultivators or encourage them to take on agriculture have long been in place, although they are being gradually canceled. This is the case in particular of the 'tafwid' mechanism which rewards those reclaiming unused land and which is unofficially more or less abandoned, although there is a likely political calculus to avoid making this fully public and official.

The second reason is that the state is loath to intervene in the moneymaking brokering mechanism setup by local Bedouins, for fear of antagonizing them. It has been shown that Bedouin tribes are a fundamental pillar of a monarchy that has always depended on a delicate balancing act whereby the flow of benefits accruing to Bedouin tribes is key to the sustaining of their political support. However, because of the conflicts resulting from taswiye 
processes, and the dynamics fueled by expectations that it would endlessly continue, the state has decided to put an end to such processes, although this is not announced as a definitive decision that would otherwise require legal changes (Chapter 5).

Claims to land ownership regarding the huge portion of the country which has never been formally titled (around 75\% of it) are a major trump card in the hands of the Bedouin population in its daily dealings with the state. It is therefore a 'hot issue' that is there to stay and explains the limitations faced by the state in quelling this source of agricultural expansion and associated water use.

Water: In Azraq basin, groundwater was easy to access as it could be found close to the surface. The availability of both legal and illegal drilling machines and equipment has long allowed local residents and investors to drill wells without bothering registering them or asking for drilling permits from the Ministry. This was also a result of most land plots being under unclear tenure status, and therefore render them unable to legalize their wells. Mafraq stands in contrast, both because land is legally owned and because the water table is much deeper. Land and water are therefore very expensive, and agriculture only makes sense for intensive and often high-tech fruit (or vegetable) production.

While investment costs in Mafraq are higher than in Azraq, running costs may comparatively be more favorable in some situations: connection to the grid allows farmers to use electricity rather than diesel. Most wells in Mafraq are licensed, which comes with a generous free block of $150,000 \mathrm{~m}^{3} / \mathrm{yr} /$ well and a cheap tariff of 5 fils for the $150,000-200,000 \mathrm{~m}^{3}$ block. In Azraq, wells with permits have a free block of $25000 \mathrm{~m}^{3} / \mathrm{du}$ but within a limit of 50,000 $\mathrm{m}^{3} / \mathrm{yr} /$ well only, while the next block (up to $100,000 \mathrm{~m}^{3}$ ) is charged at $20 \mathrm{fils} / \mathrm{m}^{3}$ and the last one $\left(>100,000 \mathrm{~m}^{3}\right)$ at $60 \mathrm{fils} / \mathrm{m}^{3}$ (Chapter 7$)$.

Just like for land, the state through the MWI has long maintained an ambiguous stance towards controlling groundwater use. Although stricter regulations were passed in 2002, the ministry initially often turned a blind eye to illegal well drilling, did not enforce pricing and operated through field offices endowed with material means and staff that were insufficient to really check the situation on the ground. But beyond means, this also reflected political uneasiness in dealing with a resource that people do not associate with the state, which they have to invest in in order to be able to use it, and which allows some rural impoverished population to make a living. Likewise, strictly controlling groundwater abstraction would antagonize Bedouins who grow fodder or other crops on unregistered land. In recent years lax enforcement has however been gradually superseded by a much stronger stance backed by fresh political will and made pressing by mounting water challenges (Chapter 6 ). Whether and how new regulatory and economic tools and measures are a game changer is discussed below.

Labor: Labor in agriculture is divided into two types: permanent labor and seasonal labor. Permanent workers stay on the farm 24/7, while seasonal workers are mobilized at harvest and planting time, according to farms' needs (Chapter 7). Cultivation in the desert usually poses the question of labor availability, because most farms are isolated and/or far from the city, access roads are unpaved, climatic condition are harsh. In Azraq, permanent laborers are mainly from Egypt and Yemen, while seasonal laborers are either locals or Syrian refugees (Chapter 7). 


\section{Chapter 8}

How do foreign laborers end up in Azraq? Foreign laborers can be obtained either legally by using the right to 'import' one foreign labor for each hectare (10 du) of cultivated land, either through an official procedure or illegally through the labor brokers (Chapter 7). Farmers and farm owners often prefer to use the second methods avoiding lengthy official procedures. Brokers are controlling the labor market in Azraq as they can sell and buy labor licenses, facilitate the travel of workers from abroad, liaise with recruitment agents in Egypt or elsewhere. They also provide farmers with seasonal daily workers, taking a commission in return (typically between 0.5 and $10 \mathrm{JD} /$ person/day) (Chapter 7).

The rule of one laborer per hectare (or $10 \mathrm{du}$ ) opened the way for abuse. It may provide farmers and officials shared incentives to overestimate the cultivated areas. But it also allows farmers to request a number of workers far in excess of their actual needs. The result is that the incoming workers are sometimes diverted to the construction sector in Amman, in exchange for a lump sum of money to the farmer (around $550 \mathrm{JD} /$ worker). This rule has now been changed: farmers have the right now to have 1 laborer for each 50 du instead of $10 \mathrm{du}$ (Chapter 7).

It is also not always easy to secure permanent labor under the unattractive conditions of desert farms. Some workers escape to Amman where they can get better salaries. Therefore, accessing labor is relatively straightforward and not a constraint to investment but securing it may be more problematic. As for seasonal workers, the influx of Syrian refugees have provided abundant and cheap labor, since they are paid at a very low wage of $1 \mathrm{JD} / \mathrm{hr}$, while the rate for Jordanians is $15 \mathrm{JD} /$ day, enhancing the profitability of labor-intensive crops, notably vegetables (Chapter 7 ).

Energy: What energy can be used in desert remote farms? When it comes to groundwaterbased agriculture, energy is considered as important as land and water, because it is needed to extract water, and run the irrigation system. Groundwater started to be extracted through pumps powered by diesel. Later on, electricity came to be increasingly used, as the power grid was extended along the main roads and was made more desirable by skyrocketing diesel prices after the Iraqi war. However, electricity is not available everywhere and, in addition, land should be legal and registered in the Land Department for a farm to qualify for a connection to the grid. Accordingly, illegal land owners either have to use diesel (at a high cost), make illegal connections to the grid, or adopt solar energy systems. From this study (Chapter 7), it was found that the average abstraction cost in Azraq and Mafraq using electricity as a source of energy amounted to 0.015 and $0.136 \mathrm{JD} / \mathrm{m}^{3}$ respectively, while the abstraction cost in Azraq using diesel energy was $0.12 \mathrm{JD} / \mathrm{m}^{3}$ (Chapter 7).

Capital: Groundwater-based agriculture requires important amounts of capital in order to buy land, drill the well, or obtain licenses. We have divided farms in four categories:

1) big farms for investment purposes (big capital to buy land, well paid farm manager or skilled labor, knowledge of the market and possibly export channels, adoption of new irrigation technologies or new ways of frost- or drought-proofing the farm, paying water and electricity bills, etc);

2) medium-to-small farms owned by locals looking for adequate profit (small market, unpaid bills, few workers, uncertainty and illegality); 
3) hobby farms for leisure (urbanites coming occasionally, with farm run by a manager; or 'Sunday farming'); and

4) small-scale family farms (home consumption, family labor).

All these types of farm are present in Azraq basin. The level of investment varies from place to place according to the area within Azraq basin. As mentioned earlier, investments in Azraq are in general less costly than in Mafraq as land is cheaper, water is nearer to the surface, and therefore energy costs for abstraction of water lower (Chapters 5, 6 and 7). Despite the lower cost, cultivation in Azraq still needs an initial capital investment of no less than 150,000 JD for a farm of $200 \mathrm{du}(\sim 5,000 \mathrm{JD} / \mathrm{du}+60,000 \mathrm{JD} /$ well). Such large farms are therefore normally owned by large investors, while small farmers prefer to cultivate an average of 20 $\mathrm{du}$, with a loan from the agricultural bank (Chapter 7).

Markets: Aside from production factors, the viability of desert farming also depends on market opportunities. Iraq and Gulf countries are considered to be the main export market for many farmers in Azraq and Mafraq, but these have been affected by the repeated crises in the region. Azraq is now producing alfalfa that is partly exported to UAE. The Syrian crisis has taken its toll on production in Syria and this, together with the food demand for the refugee camps, has opened up new market opportunities. These circumstances, however, are transient.

Azraq's agriculture is also affected by additional transportation costs for products with limited added value such as olive (oil). Farmers in Azraq either sell their olive production as olive or as oil. The production cost of olive at farm level is around $35 \mathrm{fils} / \mathrm{kg}$, the production is sold in Amman as Azraq market is small and it is sold at $45 \mathrm{fils} / \mathrm{kg}$ with no revenue to the farmer as the 10 cents difference goes to the transportation cost. As Azraq olive oil has less acidity, a characteristic that is not favored by the Jordanian market, farmers have to export it outside the country, mainly to the Gulf and Israel, which adds new costs for the farmers. Meanwhile, Mafraq is affected by additional storage costs for stone fruit trees, as each cold storage room (warehouse) with a capacity of 20 tons costs about 2,500 - 3,000 JD/year for the storage (Al Naber, 2016).

In summary, this section showed that the historical legal background and the relative costs of the production factors largely explain the differences in farm type and crop choice (summarized in Table 8-1). Mafraq attracts investors with big capital as land and wells are legal and fetch high prices, but water tariffs, water quality, road access, electrification and market channels are favorable. Risk is therefore low and high-tech fruit tree cultivation dominates. In contrast in Azraq, farmers tend to cultivate olive trees as these need less input and suit the parallel objective of land speculation, alfalfa (with illegal wells escaping water tariffs) to take advantage of the demand from Gulf Countries, while a few investors emulate the Mafraq model. Lands are often occupied and/or obtained from Bedouins in exchange for payment (much less, though, than for a privately-owned land) and not legally owned (although some areas have been the object of land settlements in the past). Wells, therefore, often only have a temporary permit (with higher water fees) or are illegal (with tariffs recently raised at prohibitive levels). Water is shallower and therefore cheaper to extract but subject to salinity hazards that increase with depth and proximity to the wetland. Risk, either legal or agronomic, is therefore higher. 


\section{Chapter 8}

Table 8-1. Accessibility of production factors in both Azraq and Mafraq.

\begin{tabular}{|l|l|l|}
\hline \multirow{2}{*}{$\begin{array}{l}\text { Production } \\
\text { factors }\end{array}$} & \multicolumn{2}{|c|}{ Azraq Basin } \\
\cline { 2 - 3 } & Azraq & Mafraq (North Badia) \\
\hline Wand & $\begin{array}{l}\text { Frequent speculation; buy legal; buy } \\
\text { illegal; inherits }\end{array}$ & $\begin{array}{l}\text { land in general private and legal (official } \\
\text { titles); high prices }\end{array}$ \\
\hline $\begin{array}{l}\text { Shallower wells, both legal or illegal; } \\
\text { illegal drilling curbed but not stopped. } \\
\text { Salinity growing and problematic in } \\
\text { some areas; higher water fees for wells } \\
\text { with permits, discouraging tariffs for } \\
\text { (registered) illegal wells }\end{array}$ & $\begin{array}{l}\text { Deep wells (almost) all licensed; illegal } \\
\text { drilling rare. Generous free block; water } \\
\text { charges minimal in production costs. } \\
\text { Good water quality }\end{array}$ \\
\hline Energy & $\begin{array}{l}\text { Diesel, electricity, solar energy as the } \\
\text { emerging cost-effective solution for } \\
\text { isolated (and/or illegal) farms }\end{array}$ & Electricity \\
\hline $\begin{array}{l}\text { Capital } \\
\text { (investment) }\end{array}$ & \begin{tabular}{l} 
Moderate \\
\hline Labor
\end{tabular} & $\begin{array}{l}\text { Brokers, permits for permanent (foreign) workers; seasonal workers from nearby } \\
\text { areas or (increasingly) from Syrian refugee camps. }\end{array}$ \\
\hline
\end{tabular}

\section{- Is desert agriculture in Azraq Basin economically viable, and environmentally sustainable? What are possible prospects for the future?}

Based on our survey's data, this research estimated the gross margin of each farm type in Azraq and Mafraq, it was found (Chapter 7) that four out of five farm typologies in Azraq got positive average incomes ranging from $50 \mathrm{JD} / \mathrm{du} / \mathrm{yr}$ up to $223 \mathrm{JD} / \mathrm{du} / \mathrm{yr}$. In Mafraq, all farm types have a higher gross margin, ranging from 1123 to $1963 \mathrm{JD} / \mathrm{du} / \mathrm{yr}$. Olive is the dominant crop cultivated in Azraq farm typology, with alfalfa and grapes cultivated intercropped with olives (or sometime alone) to enhance profit. In Mafraq, more sophisticated farms cultivated mainly with stone fruit trees, with some grape and vegetables, are linked to well-identified markets, which is reflected in the high positive returns.

In both Azraq and Mafraq energy costs followed by labor wages were shown to be the main costs in farming, which is explained by the high cost of using water illegally in Azraq, and by the depth of the water table in Mafraq. Water fees in both Azraq and Mafraq were found to be the least of all production factor costs. It can be concluded that agriculture in Mafraq is highly profitable, to the point that no foreseeable change in any of the production factor included water charges - or in the market is likely to change this conclusion. The bulk of agriculture in Azraq is moderately-to-little profitable and vulnerable to drastic changes in factor or market prices, including water charges for illegal wells. But its value includes a longer-term speculative value attached to expectations regarding land tenure conditions.

The researcher has investigated the economic sustainability in term of gross margin of Azraq and Mafraq farms for different water charge scenarios (Chapter 7). For Mafraq we found that agriculture is unlikely to be substantially affected by changes in tariffs (that are politically conceivable for legal wells), since the price of water remains secondary to other production 
factors, even if the free block is taken down from 150,000 to 50,000 $\mathrm{m}^{3}$. In Azraq, the 'all wells with permits', and 'all wells illegal' scenarios did affect gross margins but not to the point of threatening profitability, because the differential between the tariffs of the two categories are not large enough. But application of the recent tariffs for illegal wells multiplies water costs by ten, meaning that farms with illegal wells would be bankrupt right away, except high-tech/greenhouse production.

What about environmental sustainability? Since the early 2000s, many farmers in Azraq noticed a reduction in their farm productivity and profitability due to the drop in the water table and an increase in salinity. Some farmers had to deepen their well to reach water and in some cases, they reached more saline water. Associated negative impacts on yields combined with higher energy costs (after the Iraqi wars) and labor costs. As a result, a number of farms have been abandoned mainly in Azraq South and locals have left the area (a number of Chechen moved to other cities such as Wadi El Sir, Sweileh and Zarqa). Cultivation generates limited profit, as shown by the calculation of farm gross margins, but the most entrepreneurial farmers are trying to adapt to changes by converting to solar energy to decrease the long-term energy costs, changing cropping patterns and moving toward more profitable crops, planning to build desalination plants like in the south of Jordan Valley, etc. The situation in Mafraq is more stable compared to Azraq, as water tables are already deep, and farmers have the capital to adapt to changes.

However it is not all clear to what depth can groundwater still be pumped and depleted. Different scholars describe the future of groundwater-based agriculture on Jordanian highlands as bleak because of the growing costs for accessing water, retrofitting wells and pumps, increases in salinity, and the anticipated dewatering of the aquifers in some parts. A study by Rosenberg and Peralta (2012) estimated that $79 \%$ of olive and vegetable farming in Azraq might become economically unviable in the next ten years, leaving concerned farmers with the choice of either shifting to higher-value crops or quitting farming altogether. This trend anticipated in 2012 can actually now be observed on the ground, albeit not with the expected magnitude: a number of olives trees are left to dry with no production, cropping patterns where partly shifted to more economical value crops as alfalfa.

During the Highland Water Forum (a multi-stakeholder platform set up to discuss groundwater issues) held between 2010 and 2013, several ideas were proposed and discussed regarding future options in Azraq basin (Demilcamps, 2010; HWF, 2015), including adopting plants tolerant to arid environments and salinity, saving water by different farm practices and technologies, developing income-generating alternative activities such as 'solar farming' or ecotourism, or having the state buy out farms or wells (which is currently ruled out by the government). However, these mitigating measures -if implemented-are unlikely to significantly affect on-going trends.

What future can we foresee for Azraq's agriculture based on the analysis developed in this thesis, and what possible game changers are emerging? We are likely to see a polarization in Azraq, with a decline/demise of farms affected by salinity and lack of legalization prospect on the one hand, and the 'Mafraqisation' of a few farmers, on the other. This demise of agriculture will particularly affect small Chechen farms in Azraq South, who already have to deal with growing water salinity; 'Sunday farming' urbanites with temporary well permits but not willing to invest further, and/or possibly discouraged by the current lack of prospect 


\section{Chapter 8}

regarding land regularization; and above all farms based on illegal wells: their precarious status has allowed the Ministry to impose prohibitive water charges. As discussed in Chapter 6 , the effects of this policy have yet to be seen and the willingness of the government to implement it has yet to be confirmed. Economic calculations, recalled above, show that, if applied, tariffs for illegal wells would put an end to a large portion of these farms.

But some farmers are likely to emulate the Mafraq model (and indeed some investors have farms in both areas): they have the connections, capital and know-how to ever intensify, tap export markets, and shift to solar energy or even desalination of brackish water. Investments in those farms, however, will be constrained by the lack of legal security regarding land and water, with the exception of a few farms with land titles. It will therefore chiefly concern existing legal farms rather than whatever expansion might still occur.

Will the number of farms and the cultivated area be reduced? This will most probably be the case in the area near Azraq due to the different factors spelled out above. But it is also possible to see a concomitant outward expansion of farms, allowed in particular by solar energy. This will depend on the degree of resolve shown by the government in controlling this expansion by satellite images and enforcing regulations on the ground.

Two major potential game changers - that work in opposite directions - are therefore water tariffs for illegal wells and solar energy.

\subsection{Zooming out - results in perspective}

\section{What lessons can be drawn from the study of Azraq Basin for desert agriculture in the MENA region?}

We may now zoom out from our Azraq case study to the wider context of desert agriculture in the MENA region described in the introduction. How does Azraq compare with other situations, what is specific to it, and what lessons learned might be useful to other contexts?

Like in most countries of the MENA, the expansion of desert agriculture in Jordan has been fuelled by private individuals and companies, with various direct and indirect incentives extended by the state. Like in Morocco, Algeria or Egypt, the state encouraged agricultural expansion and turned a blind eye to law infringements in terms of well license, land tenure, or in some case (e.g. Egypt) even illegal diversion from state canals. Initially, such livelihood opportunity was seen as a stabilizing factor in the settling of Bedouins (UNDP, 2013b). Unlike Morocco or Egypt, it was not meant to be an 'escape valve' for impoverished peasants with tiny or no land at all in old agricultural regions. Rather, the economic opportunity was seized by medium-sized entrepreneurs, many of them already farming in the Jordan Valley (and often with a Palestinian background) or sometimes locals. While the corporate model observed in Sudan, Egypt or Morocco was able to develop on the Disi aquifer, in the south, it did not develop in the highlands. Apart from its role in the give-and-take policy of the state vis-à-vis the Bedouins or other ethnic groups settled in Azraq, desert agriculture in the highlands is mostly the domain of medium-scale investors with productive and/or speculative purposes. It is noteworthy, however, that while most countries still support the expansion of desert agriculture (e.g. Morocco with subsidized drip irrigation, Algeria with highly subsidized land grants, or Egypt with President Sisi's Million Feddan Project), Jordan is not: the MWI is somehow prevailing over the Ministry of Agriculture and staff clearly expressed to us the 
(mid-term) policy objective of basically stopping agriculture in the highlands and using groundwater only for domestic purposes.

With regard to land tenure, desert lands in Jordan, just like in Egypt, Sudan, Israel or Algeria, have been formally put under state ownership. State land located in desert/vast areas far from settlements, like in some place in Algeria, Egypt, or parts of Sudan can be leased or sold to corporations without raising much claim to land. But the situation differs in steppe lands (badia) used by Bedouins or other herders, as has been shown in Chapter 5 . In such situations Bedouins make claim to land, especially when its value is enhanced by the possibility to use groundwater, regardless of whether the State has established legal ownership/custodianship of it. This research showed that a situation of legal pluralism prevails, where claims and counter-claims are articulated within wider political frameworks whereby Bedouins try to extract some of the newly revealed value of the land. This takes place in situations where Bedouins are displaced from grazing lands (e.g. Egypt) but in many cases like in Azraq the 'areal footprint' of irrigated agriculture may remain limited. Bedouins therefore issue hijjehs (Jordan), or exact payment (khawa) dubbed as a 'protection fee' from settlers, like in Egypt. A similar well-known conflict, this time between the state and Bedouins, is that of the Negev, where the Israeli state refused to recognize Bedouins rights on claimed state lands. The state has been trying to evacuate the claimed villages by reallocating the inhabitants to what is called "Seven State Planned Bedouins" towns, while Bedouins refuse to leave the lands for which they claim to have historical rights (Meir, 2009; Shmueli and Khamaisi, 2011). This conflict ended up in courts were the Israeli state used legal and historical arguments to prove state land ownership, rejecting Bedouin claims on the ground that they do not have land deeds and lack historical evidence that land in Negev was farmed by Bedouins, as all Bedouins were nomadic pastoralists with no fixed homes, territories or settlements (Meir, 2009).

What does Azraq situation tell us about groundwater use and policy? Azraq features a ubiquitous tradeoff between well drilling/use and natural spring flow (in this case feeding an oasis) or qanats flow. In most of the region spanning from Morocco to Pakistan, this competition has resulted and is resulting in the demise of qanats and the drying up of springs (Closas and Molle, 2016). In that sense the Azraq story is not different from those other ones. The curve showing the gradual drop of both its aquifer and spring flows is, sadly, all the more common. The wetland is now artificially sustained on $5-10 \%$ of its original extent with groundwater (Hresha, 2013).

With the increase in groundwater use and associated negative impacts, the states in the MENA region have in general expressed the importance of having policy instruments to manage and control the use of this resource. To this aim, states have developed laws, by laws, decrees and various regulatory and economic tools. Many similarities have been found between these policies, as most states have implemented well registration and licensing procedures, prohibition zones in overexploited areas, metering, quotas and sometimes pricing (see introduction). But overall in the MENA region the enforcement of these regulations has been extremely varied and, in general, lax.

While some countries require only a notification for wells under a depth limit (e.g. Tunisia, Morocco and Lebanon), Jordan, like many other MENA region countries, requires a permit for both the drilling and the use of any type of well. Like Morocco or Lebanon, Jordan has faced 


\section{Chapter 8}

the challenge of legalizing unregistered wells at a certain point in time: it has given several extended legalization periods before a terminal date in 2014. The researcher found the same lack of trust towards the government intentions but also a specificity linked to the land tenure status: since the privatization of land has been suspended, all people with nonlegalized land are unable to ask for licenses: if declaring their well they will therefore be classified as illegal with temporary permits (if they can prove the 'socio-economic dimension' of their cultivation), or considered as illegal (in which case they will be temporarily tolerated but heavily taxed through water tariffs).

Jordan is therefore special with regard to legalization because there is a risk for farmers to both declare their illegal well (which will be taxed and have a precarious status) and not to declare it (given the growing pressure put on illegal wells in the past few years). While most countries try to make registration attractive or at least neutral, to encourage farmers to report their wells, in Jordan the status of such wells is actually unattractive and works against registration. The 'stick' (cost) that goes with registering must therefore be paralleled by a bigger one for those keeping their well illegal/unregistered (which at the moment is only a threat of potential tougher actions in the future).

There is a second major difference between Jordan and other MENA region countries which, typically, have between 100,000 and 300,000 wells each (Molle and Closas, 2016): Jordan only has around 4000 known legal and illegal wells, which can be explained by its smaller population, higher average drilling costs, and more limited resources. Jordan has therefore been able to close much of the gap between existing and registered wells, which other countries are far from achieving [e.g. in Lebanon, "It is believed that there are over 80,000 wells in the country, a fourth of which are registered, and a very small part of these $(\sim 300)$ are licensed and metered" (Molle et al., 2017b)]. According to official data, there are around 1000 illegal wells in Jordan out of 4000 working registered wells (although this does not account for illegal unknown wells, to be found chiefly in Azraq and in the Jordan Valley).

With regard to the volumetric control of abstraction, Jordan also distinguished itself by the higher rate of metered wells, since most wells with licenses or (temporary) permits have meters. This research has shown, however (Chapter 6), that many of these meters were nonfunctioning (around $40 \%$ in Azraq) or tampered with, which led the government to increasingly use remote sensing and proxies such as electricity consumption or area/crop characteristics to estimate use. On the one hand, Jordan, together with some Gulf Countries such as Bahrain, is one of the few countries in the region which attempt a volumetric monitoring of all groundwater users; on the other, Molle et al. (2017a) have cast doubt on the reliability of abstraction figures published by the government, by showing a clear disconnect between the evolution of groundwater-irrigated areas (doubling in the last 30 years) and total water abstraction volumes (stable over the same period). This suggests that monitoring and data collection are highly contingent.

Jordan is also noteworthy for its block-tariffs applied to groundwater abstraction. We concluded, however, that the free block granted to licensed wells and the relatively modest prices had little impact on use itself. An exception to this finding was the case of illegal wells for which this study showed that the new tariffs imposed in 2014 made agriculture unviable, except for greenhouses or very intensive cash-crop farming on small areas. In other words, while water pricing for legal wells faced the same limitations observed elsewhere in the 
world (it is close to impossible for governments to tax abstraction when its role in the provision of groundwater is nil; see Molle and Closas, 2017), and is therefore not efficient in reducing use, the Ministry has attempted to use pricing to make illegal wells unviable (the illegal nature of the well allowing the government to do so).

The problem of law enforcement is faced by all countries. This study found that controlling illegal drilling was extremely difficult; that bribing or intimidation of field staff distorted data collection and weakened policy implementation. This study revealed how farmers circumvent or evade regulations in various 'creative' ways: by-passing or tampering with meters, declaring a well-used for domestic purposes and using it for agriculture, making fake wells to be sealed by the government, etc. With bribing found everywhere in the region and beyond (Syria, Morocco, Lebanon, Egypt, Yemen, etc., see Closas and Molle, 2016), to get a permit or have officials turn a blind eye to an illegal well, Jordan does not escape this problem, albeit probably with a lower intensity.

Another noteworthy specificity of Jordan's groundwater policies is the set of indirect measures directed at other production factors involved in cultivation: this involves reducing access to foreign workers, not connecting illegal wells to the grid, freezing the distribution/privatization of state land and, last but not least, interconnecting ministries' data system to deprive of public services users who have not paid their water bills. To what can be added a 'name and shame' policy whereby violators' names are published in newspapers and on the web. This experience is certainly original and of great value to other countries globally.

All in all, and despite the various difficulties faced when enforcing regulations, Jordan stands out as the country in the MENA region that has both displayed the largest array of policy tools and regulations, and shown -at least at the ministerial level- a political will that is sorely lacking in most other countries. The effectiveness of the recent measures has yet to be assessed and will probably be dampened by several types of constraints at all levels of the society; but they are unparalleled in the region. We can speculate that this is due in part to Jordan having extremely limited water endowments, with surface waters largely coming from/controlled by Israel and Syria, and a general state of groundwater overexploitation; to its smaller population; and to the limited power/relative importance of the agricultural sector.

The availability of labor in desert areas of the MENA region was also found to be varied, as each country has its own specificity: agricultural labor in Jordan and Gulf countries normally comes from Egypt and Yemen and can be obtained easily through official procedures or through labor brokers. In Egypt, the situation is less favorable since it is harder to attract labor as permanent workers in desert conditions and with the salaries proposed in Egypt. For Algeria and Morocco, this study has found little reporting of labor problems which suggests it is not a major obstacle to farming in desert.

The source of energy for desert agriculture in the past was mainly diesel (or benzene), with prices and levels of subsidy decreasing and increasing according to the international price of oil and the regional political situation. Farmers shifted to electricity whenever available because in general it was cheaper (although also sometimes partly due to subsidies). But land and wells should be legal in order to get the benefits of using electricity and lower water prices. There is therefore an opportunity to use the power grid to restrict use (and therefore water abstraction), as implemented in India, for example (Shah, 1997), but the recent 


\section{Chapter 8}

availability of cheap solar panels is ruining that option: this trend is also emerging in other MENA countries such as Morocco or Algeria and will clearly be a 'hot issue' in coming years.

Last, this research found that investing in desert agriculture did require substantial capital, most especially in Mafraq, which dictates a highly productive high-tech agriculture. This is less the case in Azraq, but illegal well drilling, hijjeh for land, and energy costs (not to mention the growing risk) have dramatically reduced profitability. Therefore, desert agriculture is more expensive than in Algeria, where all factors are subsidized, Morocco, where collective lands can be negotiated at a low price or leased by the state, or even Sudan, where cultivation was promoted and subsidies provided to successive large-scale national development plans (Fragaszy and Closas, 2016).

With no possibility to transfer surface water (like in Egypt, Morocco or Tunisia), a very high rate of reuse of treated wastewater, and a general situation of overexploitation of its resources, controlling the expansion of groundwater use in Jordan is the highest priority. Only then can efforts to curb existing use through various incentives - with the drastic limitations made explicit in this thesis - make sense. But, because of both their limited scope and political constraints, the government is acknowledging that its policies will not be enough to respond to the increasingly deteriorated demand/supply ratio and is moving toward seawater desalination as its last trump card.

\subsection{Implications for the conservation and sustainable use of groundwater}

This thesis aimed to contribute to the conservation and sustainable use of limited groundwater resources in desert agriculture. An extensive review indicated that all MENA countries are suffering from overabstraction. Groundwater is mined with no consideration of what is called 'safe yield'. In terms of sustainability, policies and management approaches focus on exploiting aquifers with an allowable abstraction rate close to the safe yield. However, actual use is far beyond the safe yield and, in some countries like Jordan and Yemen, reached a point of irreversible action: groundwater abstraction cannot be reduced below the safe yield. Therefore, it is necessary to define a negotiated allowable abstraction rate that aims at extending the aquifer lifetime instead of sustaining it. The way of defining this theoretical number vary from aquifer to aquifer, but it is mainly based on the physical geography of the aquifers, social needs and water demand priorities.

In terms of conservation, this study showed, as illustrated in Figure 8-2, that the system of groundwater-based agriculture is highly complex. Numerous interconnected issues and conditions drive groundwater-based agriculture systems in the MENA region. The system is driven by land accessibility, water availability and easy accessibility, labor availability, energy options, and feasible alternatives. Therefore, this analysis shows that there is not a standard, single silver bullet recommendation that could, typically, include enforcing laws and regulation, sealing illegal wells, improving hydrogeological knowledge, incentivizing crops with low water consumption, etc. Such conventional advice ignores the societal, political and more systemic constraints that will not be removed by wishful thinking. Rather, we have focused on understanding these constraints and documenting how and to what degree the government was working to remove them. The original and (so far) partly successful measures implemented are specific to Jordan's physical and socio-political equation and cannot be easily transferred elsewhere. 
Yet, as indicated above, they may provide inspiration to other countries and tend to substantiate the facts that indirect measures are more likely to be effective, or that several combined 'sticks' and 'carrots' measures must be brought to bear at the same time. Water policies in Jordan illustrated how to tackle over abstraction through a combination of direct and, more interestingly, indirect measures: impossibility to obtain well licenses or permits, labor permits, connection to the electricity grid without proving formal land ownership; freezing settlement and delegation processes; raising tariffs on illegal wells; 'naming and shaming' defaulters, etc. Metering use has proved to be fraught with severe technical and social difficulties and the use of proxies (e.g. through remote sensing) emerge as alternative options.

The problem of groundwater-based agriculture and overexploitation of aquifers is a vexing problem worldwide and has been shown to have many interconnected ramifications. All factors should be unpacked and analyzed with due consideration given to societal and sociopolitical constrains to identify the right management approach allowing to extend the lifetime and availability of the resource. 
REFERENCES 


$$
\text { - }
$$

\section{.}


Aarnoudse, E., Bluemling, B., Wester, P. and Qu, W., 2012. The role of collective groundwater institutions in the implementation of direct groundwater regulation measures in Minqin County, China. Hydrogeology Journal, 20(7), pp.1213-1221.

Abbadi, E., 2003. 108 artesian wells backfilled (in Arabic). Addoustor newspaper. www.addustour.com/13254 (accessed February 2017).

Abd Al Hadi, W., 2014. Distribution of Ma'an lands, caused confusion among the tribes of south Jordan. Alarabalyawm Newspaper. http://alarabalyawm.net/?p=125456.

Abderrahman, W.A., 2003. Should intensive use of non-renewable groundwater resources always be rejected?. Intensive Use of Groundwater: Challenges and Opportunities, pp.191-203.

Abderrahman, W.A., 2005. Groundwater management for sustainable development of urban and rural areas in extremely arid regions: A case study. International Journal of Water Resources Development, 21(3), pp.403-412.

Abdulla, F.A., Al-Khatib, M.A. and Al-Ghazzawi, Z.D., 1999. Development of groundwater modeling for the Azraq Basin, Jordan. Environmental Geology, 40(1), pp.11-18.

Abed, M., 2015. Tribal lands: between historic rights" and legal fuzziness (In Arabic). Hawkameh online Newspaper. http://arij.net/report.

ABHSMD, 2005. Stratégie de préservation des ressources en eau souterraine dans le bassin du Souss Massa- Plan d'action 2005-2020, 61.

ABHSMD, 2007. Contexte général du PDAIRE. Etude de Révision du Plan Directeur d’Aménagement Intégrées Ressources en Eau (PDAIRE) des bassins du Souss Massa. Volume 1.

Abu Jaber, N., 2001. Geochemical evolution and recharge of the shallow aquifers at Tulul al Ashaqif, NE Jordan. Environmental Geology, 41(3), pp.372-383.

Abu-Ajamieh, M.M., Bender, F. and Eicher, R.N., 1988. Natural resources in Jordan: inventory, evaluation, development program. Natural Resources Authority.

ADA, 2013. Agency for Agricultural Development of Morocco. Website: www.ada.gov.ma. Accessed 23 Mar 2013.

Addamat, R.A., Baban, S.M. and Forster, I., 2006. Modelling nitrate leaching in the Azraq Basin/Jordan using GIS. In The 2nd International Conference on Water Resources and Arid Environment.

Addustour, 2004. Amendments in groundwater price for agriculture wells (in Arabic). www.addustour.com/13540/ (accessed February 2017).

Addustour, 2013. Illegal driller was detained in Mafraq (in Arabic). www.addustour.com/17800/ (accessed February 2017).

Adnane, M., 1989. Communication sur : "Le régime juridique de l'eau au Maroc », Centre National de Documentation, No. 9341, 90-1524, http://archives.cnd.hcp.ma/uploads/news/90-1524.pdf (Accessed 3rd March 2014).

Adriansen, H.K., 2007. Rural childhoods in Egypt's desert lands (No. 2007: 15). DIIS Working Paper.

Adriansen, H.K., 2009. Land reclamation in Egypt: a study of life in the new lands. Geoforum, 40(4), pp.664-674. 
Agroberichten, 2016. The future of potatoes in the Algerian desert. Online newspaper. http://www.agroberichtenbuitenland.nl/marokko/the-future-of-potatoes-in-the-algerian-desert/.

Ainnews, 2011. Tribal Land Files Between Al Srours' (Parliament President) Scenarios and the Mysterious Truth. Ainnews online Newspaper. http://ainnews.net/?p=66015.

Al Bakri, J.T., 2015. Crop mapping and validation of ALEXI-ET in Azraq and Mafraq areas. A report for Regional Coordination on Improved Water Resources Management and Capacity Building, Ministry of Water and Irrigation, Amman, Jordan.

Al-Eisawi, D., 1995. Flora and Vegetation of Azraq Wetland Reserve. Azraq Oasis Conservation Project. RAMSAR and The World Bank, pp. 72.

Al-Eisawi, D.M., 2012. Innovative solutions to reduce threats affecting biodiversity conservation. Pakistan Journal of Botany, 44, pp.157-163.

Al Insari, M.S., 2013. The water demand management in the Kingdom of Bahrain. International Journal of Engineering and Advanced Technology, 2(5), pp.544-554.

Al Khatab, A., 2014. Ma'an Land: royal vision rather that political solution. Al Rai newspaper. www.alrai.com/article/631070.html.

Al Khatatbeh, K., 2006. Ministry of Water and Irrigation supports the Miri land delegation for agriculture purpose, with some reservations due to water scarcity. Addustour Newspaper. www.addustour.com/

Al Moghrabi, M., 2014. Details about Ma'an land distribution, and an expert: no discrimination in the decision. Khaberni online Newspaper. http://khaberni.com/.

Al Muala, 2008. zarqa land: the end of decades of suffering. Al-Sijill online Newspaper. www.alsijill.com/sijill_items/sitem3964.htm.

Al Naber, M., Todorovic, M., Shatanawi, M., Flichman, G. and Scardigno, A., 2010. Water allocation strategies under drought and specific socio-economic and environmental conditions in the Central Jordan Valley. Options Méditerranéennes. Série A, Séminaires Méditerranéens, (95), pp.259-265.

Al Naber, M., 2016. Jordan - Azraq Basin case Study. Groundwater governance in the Arab world. IWMI project report no 12. IWMI and USAID. 107 pp.

Al Naber, M. and Molle, F., 2016. The politics of accessing desert land in Jordan. Land Use Policy, 59, pp.492-503.

Al Naber, M. and Molle, F., 2017. Controlling groundwater over abstraction: state policies vs local practices in the Jordan highlands. Water policy, 19, pp.692-708.

Al Raggad, M., 2007. Azraq: story of the Place. Presentation slides. The University of Jordan Water and Environment research and study center (WERSC).

Al Raggad, M. and Jasem, H., 2010. Managed aquifer recharge (MAR) through surface infiltration in the Azraq basin/Jordan. Journal of Water Resource and Protection, 2(12), pp.1057-1070.

Al Raggad, M., 2015. Implications of Historical transformation of groundwater system in Azraq basin. Groundwater Governance in the Arab World: Taking Stock and Addressing the Challenges, Research Update on Groundwater Policy, Management, Water Governance and Future Challenges in Azraq Basin, Jordan workshop. 
Al Zubi, Y.A., 2009. Application of analytical hierarchy process for the evaluation of climate change impact on eco hydrology: the case of Azraq basin in Jordan. Journal of Applied Sciences, 9(1), pp.13541.

Algérie, 2005. Loi n05-12 du 28 Joumada Ethania 1426 correspondant au 4 août 2005 relative à l'eau. Journal Officiel de le République Algérienne.

Al-Jamal, K., 1996. Wastewater reuse in agriculture in Gaza Strip Governorates. Proceedings of the workshop on groundwater protection in the Arab Region, RIGW/UNESCO, Cairo, Egypt.

Allan, J.A., 2001. The Middle East Water Question: Hydropoliticsand the Global Economy.

Allofjo, 2012. Ministry of Interior begins consideration of a request by 4 thousands of tribal land. www. allofjo.net/index. php?page=article\&id=23343\#sthash. $m 7 i e A P v 5$. dpuf.

Allofjo, 2014. Ma'an reject itself from the royal dedication. Allofjo online Newspaper. http://www.allofjo.net/index.php?page=article\&id=62967.

Alon, Y., 2007. The Making of Jordan. Tribes, Colonialism and the Modern State. New York: I.B. Tauris, $232 \mathrm{pp}$.

AlRabeenews, 2015. AlZalabieh tribes asking the king to be exempted from paying the land fees. AlRabeenews online Newspaper http://www.alrabeenews.com/.

Al-Sirhan, S., 1998. Managing Rangelands: Learning from Institutional Experience in order to Promote Bedouin Participation in the Badia of Jordan. Master Thesis Durham University.

Alvarez, S., Paas, W., Descheemaeker, K., Tittonell, P. and Groot, J.C.J., 2014. Constructing typologies, a way to deal with farm diversity: general guidelines for the Humidtropics. Plant Sciences Group, Wageningen University, the Netherlands.

Alwakeelnews, 2015. Ministry of Water and Irrigation published the names of illegal wells owners who did not pay for water bills (in Arabic). Alwakeelnews online newspaper. www.alwakeelnews.com/print.php?id=89851 (accessed February 2017).

Al-Zubari, W.K., 2014. Synthesis report on groundwater governance regional diagnosis in the Arab Region. Groundwater Governance - A Global Framework for Action. GEF and FAO.

Al Zu'bi, Y., 2001. Multi-criteria Analysis for Water Productivity in Azraq Basin, Jordan. Regional Conference on Water Demand Management, Conservation and Control 1-17.

Al-Zu'bi, Y. and Al- Kharabsheh, A., 2003. Multicriteria analysis for Water Productivity in the Jordan Valley. Journal of Water International, 28, pp.501-511.

Amichi, F., Bouarfa, S., Lejars, C., Kuper, M., Hartani, T., Daoudi, A., Amichi, H. and Belhamra, M., 2015. Des serres et des hommes: des exploitations motrices de l'expansion territoriale et de l'ascension socioprofessionnelle sur un front pionnier de l'agriculture saharienne en Algérie. Cahiers Agricultures, 24(1), pp.11-19.

APEFEL, 2014. Website. http://apefel.com/secteur-fruits-legumes-r14/apercu-general-c68

Arabian Business, 2016. Online article. http://arabic.arabianbusiness.com/politicseconomics/2016/may/14/413386.

Arraf, F., 2016. The Agriculture sector and its Impact on Syria's Water Basins Between 1980 - 2010. European Journal of Geography, 7(3), pp.25-40. 
Arsalan, F.A., 1976. Geologie und Hydrogeologie der Azraq-Depression (Ost-Jordanien) (Doctoral dissertation, Rheinisch-Westfälische Technische Hochschule).

Ashford, L., Smith, R., De Souza, R., Fikree, F. and Yinger, N., 2006. Creetingd Window of Opportunity for Policy Change: Incorporating Evidence into Decentralized Planning in Kenya. Bulletin of the World Health Organization, 84 (8), pp.669-672.

Assawsana, 2015. 555 illegal wells backfilled (in Arabic). Assawsana online newspaper. www.assawsana.com/portal/pages. php?newsid=200718 (accessed February 2017).

Aw-Hassan, A., Rida, F., Telleria, R. and Bruggeman, A., 2014. The impact of food and agricultural policies on groundwater use in Syria. Journal of hydrology, 513, pp.204-215.

Bachta, M.S., Zaibet, L. and Albouchi, L., 2005. Impact assessment of water resources development in the Merguellil basin: Kairouan, Tunisia. Report for the Comprehensive Assessment of Water Management in Agriculture. International Water Management Institute, Colombo, Sri Lanka.

Baer, G., 1957. Land tenure in the Hashemite kingdom of Jordan, Land Economics, 33(3), pp.187-197.

Bajjali, W., 1990. Isotopic and hydrochemical characteristics of precipitation in Jordan. Unpublished M. Sc. Thesis. University of Jordan.

Bajjali, W. and Al-Hadidi, K., 2005. Hydrochemical evaluation of groundwater in Azraq Basin, Jordan using environmental isotopes and GIS techniques. In 25th annual ESRI international user conference, San Diego, California (pp. 25-29).

Baker, M., 1956. Princess Alia Project: Interim report. Rochester Michael Baker. Harza Engineering Co.

Bakir, H., 2001. Water demand management and pollution control: Key to securing and safeguarding the water supplies of MENA in the 21st century. UN.

Barber, W. and Carr, D.P., 1973. Digital Model of Shallow Aquifer Complex of the Azraq Basin East Jordan, Consultant's Report, Development and Use of the Groundwater Resources of Eastern Jordan. $\mathrm{FAO} / \mathrm{SEJOR} / 71 / 525$.

Barnes, J., 2012. Pumping possibility: Agricultural expansion through desert reclamation in Egypt. Social Studies of Science, 42(4), pp.517-538.

Barthelemy, Y., Buscarlet, E., Gomez, E. and Janjou, D., 2010. Jordan Aquifers Modelling Project-Final Report.

Bekkar, Y., Kuper, M., Errahj, M., Faysse, N. and Gafsi, M., 2009. On the Difficulty of Managing an Invisible Resource: Farmers' Strategies and Perceptions of Groundwater Use, Field Evidence from Morocco. Irrigation and Drainage, 58, pp.252-263.

Bellal, S.A., Mokrane, S., Ghodbani, T. and Dari, O., 2015. Ressources, usagers et gestionnaires de l'eau en zone semi-aride: Le cas de la wilaya d'Oran (ouest algérien). Territoire en mouvement Revue de géographie et aménagement. Territory in movement Journal of geography and planning, (25-26).

Ben Hamouda, M.F., 2008. Approche hydrogeochimique et isotopique des systemes aquiferes cotiers du Cap Bon : cas des nappes de la cote orientale d'el Haouari, Tunisie, PhD thesis, Institut National Agronomique de Tunisie.

Ben Hounet, Y., Casciarri, B., Dupret, B., Ireton, F. and Wilson, A., 2011. Pratiques de l'appropriation foncière en contexte musulman. Transcontinentales. Sociétés, idéologies, système mondial, (10/11). 
Benblidia, M., Bleu, P. and Antipolis, S., 2011. L'efficience d'utilisation de l'eau et approche économique. Plan Bleu, Centre d'Activités Régionales PNUE/PAM, Etude nationale, Algérie, 2011, pp. 9-12.

Berahmani, A., Faysse, N., Errahj, M. and Gafsi, M., 2012. Chasing water: Diverging farmers' strategies to cope with the groundwater crisis in the coastal Chaouia region in Morocco. Irrig and Drainage 61(5) DOI: 10.1002/ird.1673.

Bin Muhammad, G., 1999. The Tribes of Jordan at the Beginning of the twenty-first century. Jam'îyat Turāth al-Urdun al-Bāqī.

Bisson, J., 2003. Mythes et réalités d'un désert convoité: le Sahara. Editions L'Harmattan.

Boctor, L., 2007. Egypt : desert reclamation the country's best hope - or a mirage. Online artilce. Inter Press Service News Agency. http://www.ipsnews.net/2007/07/egypt-desert-reclamation-thecountrys-best-hope-or-a-mirage/.

Bouziane, M., 2010. The state from below: local governance practices in Jordan. Journal of Economic and Social Research 12(1), pp.33-61.

Bravo, G. and Marelli, B., 2008. Irrigation systems as common-pool resources. Examples from Northern Italy. Journal of Alpine Research/ Revue de géographie alpine, 96(3), pp.15-26.

BRLI and Agro-Concept, 2012. Gestion de la demande en eau dans les pays méditerranéens : gestion de la demande en eau - étude de cas du Maroc, Décembre 2012.

Brooks, D.B. and Wolfe, S., 2007. Water Demand Management as Governance: Lessons from the Middle East and South Africa. Water Resources in the Middle East: Israel-Palestinian Water IssuesFrom Conflict to Cooperation, 2, pp.311.

BGR and WAJ, 1994. Groundwater Resources of Northern Jordan. Structural Features of the Main Hydrogeological Units in Northern Jordan Report vol. 3. Amman, Jordan.

Brown, J.F., Loveland, T.R., Ohlen, D.O. and Zhu, Z. 1999. The Global Land-Cover Characteristics Database: The Users' Perspective. Photogrammetric Engineering and Remote Sensing, v. 65, no. 9, pp. $1069-1074$.

Bunton, M., 2007. Colonial Land Policies in Palestine, 1917-1936. Place of publication: Oxford University Press.

Burchi, S., and D'Andrea, A., 2003. Preparing national regulations for water resources management. Principles and Practice, FAO Legislative Study No.80, Rome: Food and Agriculture Organization of the United Nations.

Burke, J.J. and Moench, M.H., 2000. Groundwater and society: resources, tensions and opportunities. Themes in groundwater management for the twenty-first century. Department of International Economic and Social Affairs, Statistical Office, United Nations.

Burt, C.M., 2004. Rapid field evaluation of drip and microspray distribution uniformity. Irrigation and Drainage Systems, 18(4), pp.275-297.

Carroll, L., 2011. Building farmsteads in the desert: capitalism, colonialism, and the transformation of rural landscapes in Late Ottoman period Transjordan. In The Archaeology of Capitalism in Colonial Contexts (pp. 105-120). Springer New York. 
Casciarri, B., 2015. Ethnographie des pratiques légales autour de la revendication des droits fonciers chez les groupes pastoraux de l'État de Khartoum. L'Année du Maghreb, 13, pp.39-60.

Charalambous, A. N., 2016. The fossil Ram sandstone aquifer of Jordan: hydrogeology, depletion and sustainability. Quarterly Journal of Engineering Geology and Hydrogeology, pp.2015-060.

Chebaane, M., El-Naser, H., Fitch, J., Hijazi, A. and Jabbarin, A., 2004. Participatory groundwater management in Jordan: Development and analysis of options. Hydrogeology Journal, 12(1), pp.14-32.

Chevalking, S., Knoop, L. and Steenbergen, F., 2008. Ideas for Groundwater Management. Wageningen, The Netherlands; MetaMeta and IUCN. 144 pp.

Chirenje, L.I., Giliba, R.A. and Musamba, E.B., 2013. Local communities' participation in decisionmaking processes through planning and budgeting in African countries. Chinese Journal of Population Resources and Environment, 11(1), pp.10-16.

Choukr-Allah, R., Nghira, A., Hirich, A. and Bouchaou, L., 2017. Water Resources Master Plan for Sustainable Development of the Souss-Massa River Basin. The Souss-Massa River Basin, Morocco, pp.1-26.

Closas, A. and Molle, F., 2016. Groundwater governance in the middle east and North Africa. IWMI Project report No. 1. USAID. 193 pp.

Closas, A., Imache, A., and Mekki, I., 2017. Groundwater governance in Tunisia. A Policy White Paper. IWMI, USAID, 43 pp.

Danielson, J. J. and Gesch, D.B., 2011. Global multi-resolution terrain elevation data 2010 (GMTED2010). U.S. Geological Survey Open-File Report 2011-1073. 26 pp.

Daoud, R.E., Naber, H., Abu, M., Tarbush, K.Q., Salman, A. and Karablieh, E., 2006. Environmental Issues of Water Resources. Water Resources in Jordan. Evolving Policies for Development, the Environment, and Conflict Resolution. Washington, pp.88-115.

Daoudi, A. and Colin, J.P., 2016. Land policy and land markets on the agricultural frontier in arid Algeria. In proc. The 17th Annual Land and Poverty Conference 2016: Scaling up Responsible Land Governance (pp. 1-26).

Dayeh, S., and Naganuma, H., 2009. Tribes, land and management in Jordan between past and present. Al Kuwait University. The Social Science Journal, 37(4), pp.11-44.

Dayton-Johnson, J., 2000. Determinants of collective action on the local commons: a model with evidence from Mexico. Journal of Development Economics, 62(1), pp.181-208.

De Châtel, F., 2014. The role of drought and climate change in the Syrian uprising: Untangling the triggers of the revolution. Middle Eastern Studies, 50(4), pp.521-535.

Del Vecchio, K., 2013. Une politique contractuelle sans contrôle? La régulation des ressources en eau souterraine dans la plaine du Saiss au Maroc, Mémoire de Master 2, Université Lumière Lyon 2, Sciences Po Lyon.

Demilecamps, C. and Sartawi, W., 2010. Farming in the desert, analysis of the agricultural situation in Azraq Basin. German-Jordanian Programme "Management of Water Resources." Deutsche Gesellschaft für Internationale Zusammenarbeit (GIZ) GmbH, Amman, Jordan.

Demmak, A., 2010. Réalisation de l'étude d'actualisation du plan national de l'eau. Programme MEDA de l'Union Européenne, Alger, Algérie. 
Dixon, M., 2017. Plastics and Agriculture in the Desert Frontier. Comparative Studies of South Asia, Africa and the Middle East, 37(1), pp.86-102.

DLS, (Various years: 1974, and from 2000 to 2013). Land Code Law. Jordan: Jordan Department of Land and Survey.

DLU, 1994. Solis in Jordan. Department of Land Use Report, DLU, Amman, Jordan.

DoS, 2008. Annual Report. Department of Statistics, Amman, Jordan.

DoS, 2010. Annual report. Department of Statistics, Amman, Jordan.

DoS, 2014. Labor Statistics in Jordan (in Arabic)., Amman, Jordan.

DoS, 2015. Crops statistics. Department of Statistics. www.dos.gov.jo/sdb/agr/agr_e/index.htm

DoS, 2017. Online Data. www.dos.gov.jo.

Dottridge, J.A.N.E., 1998. Water resources quality, sustainability and development. Arid land resources and their management, Jordan desert margin, pp.67-80.

Doukkali, R., 2011. Gestion de la Rareté et Valorisation de l'Eau d'Irrigation: Modèle Economique Intégré de Gestion de l'Eau d'Irrigation au Niveau du Bassin Versant-Cas du Bassin du Souss-Massa. Actes de l'atelier de lancement du.

Dupret, B., 2007. Legal pluralism, plurality of laws, and legal practices: theories, critiques, and praxiological re-specification. Eur. J. Legal Stud., vol. 1, pp. 296.

El Arabi, N.E. and Dawoud, M.A., 2012. Groundwater aquifer recharge with treated wastewater in Egypt: Technical, environmental, economical and regulatory considerations. Desalination and Water Treatment, 47(1-3), pp.266-278.

El Naqa, A., Al Momani, M., Kilani, S. and Hammouri, N., 2007. Groundwater deterioration of shallow groundwater aquifers due to overexploitation in northeast Jordan. Clean, 35(2), pp.156-166.

El Naqa, A. and Al-Shayeb, A., 2009. Groundwater protection and management strategy in Jordan. Water resources management, 23(12), pp.2379-2394.

El Naser, H., 2013. Interview 'Program 60 Minutes', www.youtube.com/watch?v=QSvBDfz4ptU (accessed February 2017).

El-Agha, D.E., Closas, A. and Molle, F., 2017. Below the radar: the boom of groundwater use in the central part of the Nile Delta in Egypt. Hydrogeology Journal, pp.1-11.

ElHadj, E., 2004. Camels don't fly, deserts don't bloom: an assessment of Saudi Arabia's experiment in desert agriculture. Occasional paper, (48), pp.6.

Elmore, A.J., Manning, S.J., Mustard, J.F. and Craine, J.M., 2006. Decline in alkali meadow vegetation cover in California: the effects of groundwater extraction and drought. Journal of Applied Ecology, 43(4), pp.770-779.

El-Naqa, A., 2010. Final Report Study of salt water intrusion in the Upper Aquifer in Azraq Basin. IUCNInternational Union for Conservation of Nature.

Famiglietti, J.S., 2014. The global groundwater crisis. Nature Climate Change, 4(11), pp.945-948.

FAO, 1997. Irrigation in the Near East Region in Figures. Water Report 9. Rome: FAO. 
FAO, 2003. Groundwater Management the Search for Practical Approaches, Water Reports (25): 41.

FAO, 2008a. Etude de cas du Maroc, Etude sur la gestion des eaux souterraines dans les pays pilotes du Proche Orient, Bureau regional de la FAO pour le Proche-Orient.

FAO, 2008b. Rapport Algérie, Etude sur la gestion des eaux souterraines dans les pays pilotes du Proche-Orient, Bureau régional de la FAO pour le Proche-Orient.

FAO, 2009a. Groundwater management in Saudi Arabia, Draft Synthesis Report. 14 pp.

FAO, 2009b. Irrigation in the Middle east region in figures. Water report 34. 423 pp.

FAO, 2009c. Groundwater Management in Tunisia, Draft Synthesis Report, Rome: Food and Agriculture Organisation of the United Nations.

FAO/IIASA/ISRIC/ISSCAS/JRC, 2009d. Harmonized World Soil Database (version 1.1).

FAO, 2010. AQUASTAT - FAO's global information system on water and agriculture, FAO, http://www.fao.org/nr/aquastat.

FAO, 2015. Global Diagnostic on Groundwater Governance. Special Edition for WWF7.

Farag, F., 2003. Green desert- at what cost?. Online artilce, Al Ahram weekly on-line newspaper. http://weekly.ahram.org.eg/Archive/2003/622/fe1.htm.

Faysse, N., Hartani, T., Frija, A., Marlet, S., Tazekrit, I., Zaïri, C. and Challouf, A., 2011. Usage agricole des eaux souterraines et initiatives de gestion au Maghreb: défis et opportunités pour un usage durable des aquifères.

Faysse, N. and Petit, O., 2012. Convergent readings of groundwater governance? Engaging exchanges between different research perspectives. Irrigation and Drainage, 61(S1), pp.106-114.

Firro, K., 1992. A History of the Druzes (Vol. 1). Brill.

Fischbach, M.R., 2000. State, society, and land in Jordan (Vol. 75). Brill.

Fitch, J.B., 2001. Curtailment of groundwater use for irrigated agriculture in the Amman-Zarqa basin. Uplands: An economic analysis. Report prepared for USAID. USAID, Amman.

Flindt Jørgensen, L., Villholth, K.G. and Refsgaard, J.C., 2016. Groundwater management and protection in Denmark: a review of pre-conditions, advances and challenges. International Journal of Water Resources Development, pp.1-22.

Fragaszy, S. and McDonnell, R., 2016. Oasis at a crossroads: agricultureand groundwater in LIWA, United Arab Emirates. IWMI project report No. 15. Groundwater governance in the Arab World. USAID. $72 \mathrm{pp}$.

Frija, A., Chebil, A., Speelman, S. and Faysse, N., 2014. A critical assessment of groundwater governance in Tunisia. Water Policy, 16(2), pp.358-373.

Fulmer, M., 2000. Desert farmer taps into global markets. Online artilce, Los Angeles Times. http://articles.latimes.com/2000/oct/08/business/fi-33244.

Furr, A. and Al-Serhan, M., 2008. Tribal Customary Law in Jordan. South Carolina Journal of International Law and Business, 4(2), pp.3. 
Garduno, H., Romani, S., Sengupta, B., Tuinhof, A. and Davis, R., 2011. India Groundwater Governance case study. Water paper, water partnership program, $81 \mathrm{pp}$.

Gaubi, E., 2008. La gestion des eaux souterraines en Tunisie, Bureau regional de la FAO pour le Proche-Orient, Food and Agriculture Organization.

Gaur, S., Chahar, B.R. and Graillot, D., 2011. Analytic elements method and particle swarm optimization based simulation-optimization model for groundwater management. Journal of hydrology, 402(3), pp.217-227.

Gerber, H., 1986. A new look at the Tanzimat: The case of the Province of Jerusalem. Palestine in the Late Ottoman Period, pp.30-45.

Géroudet, C. and INA, P., 2004. Démographie et histoire agraire du bassin versant du Merguellil, Tunisie centrale. INA PG, Décembre.

Gertel, J., Rottenburg, R. and Calkins, S. eds., 2014. Disrupting territories: Land, commodification \& conflict in Sudan. Boydell \& Brewer Ltd.

Ghazouani, W., Marlet, S., Mekki, I., Harrington, L.W. and Vidal, A., 2012. Farmers' Practices and Community Management of Irrigation: Why do They not Match in Fatinassa Oasis?. Irrigation and drainage, 61(1), pp.39-51.

Ghiotti, S. and Riachi, R., 2013. La gestion de l'eau au Liban: une réforme confisquée?. Etudes rurales, (2), pp.135-152.

Gijsman, A.J., Thornton, P.K. and Hoogenboom, G., 2007. Using the WISE database to parameterize soil inputs for crop simulation models. Computers and Electronics in Agriculture, 56, pp.85-100.

GIZ, 2010. Farming in the Desert Analysis of the Agricultural Situation in Azraq Basin. 84 pp.

Goode, D. J., 2012. Groundwater Level and Selling 80 Trends in the Azraq, Dead Sea, Hammad, Jordan Side Valleys, Yarmouk, and Zarqa Groundwater Basins, Jordan, 2011. Executive summary. USGS, Virginia.

Goode, D.J., Senior, L.A., Subah, A. and Jaber, A., 2013. Groundwater-level trends and forecasts, and salinity trends, in the Azraq, Dead Sea, Hammad, Jordan Side Valleys, Yarmouk, and Zarqa groundwater basins, Jordan (No. 2013-1061). US Geological Survey.

Gorelick, S. M. and Zheng, C., 2015. Global change and the groundwater management challenge, Water Resour. Res., 51, 3031-3051, doi:10.1002/2014WR016825.

Goswami, R., Chatterjee, S. and Prasad, B., 2014. Farm types and their economic characterization in complex agro-ecosystems for informed extension intervention: study from coastal West Bengal, India. Agricultural and Food Economics, 2(1), pp.5.

Griffiths, J., 1986. What is legal pluralism? Journal of Legal Pluralism, 24, pp.1-55.

Gül, A., Rida, F., Aw-Hassan, A., and Büyükalaca, O., 2005 Economic analysis of energy use in groundwater irrigation of dry areas: a case study in Syria, Applied Energy, 82, pp.285-299.

Guru, M.V. and Horne, J.E., 2000. The Ogallala Aquifer. The Kerr Center for Sustainable Agriculture. Inc., Poteau, OK, pp.32. 
Haiste in association with Scott Wilson Kirkpatrick, 1995. Qa Disi aquifer study. Final report on long term management of aquifer resources, Volume IIIB. Unpublished report, UK ODA Technical Cooperation Programme ; Ministry of Water and Irrigation, Amman, London.

Halah, A., 2007. National Dialogue for Azraq Water Basin, Environmental Sector Report. 25 pp.

Hamdane, A., 2014. La gestion des ressources en eau souterraines (nappes et aquiferes) comme biens communs: Cas de la Tunisie, Synthese regionale sur l'approche economique de la gestion de la demande en eau en Mediterranee, SCET-Tunisie.

Hamdane, A., 2015. Le contrôle de l'utilisation des eaux souterraines et la gestion participative des nappes. Report to FAO.

Hammani, A., Hartani, T., Kuper, M. and Imache, A., 2009. Paving the way for groundwater management: transforming information for crafting management rules. Irrigation and Drainage, $58(S 3)$.

Handley, C.D., 2000. Water stress: some symptoms and causes; a case study of Ta'iz, Yemen (Doctoral dissertation, School of Oriental and African Studies (University of London).

Hanson, B., 2000. Technical Report: Irrigation Advisory Services Program in the Highlands. Report to USAID. USAID, Amman- Jordan.

HCST, 1993. Investing in our common future. The Badia rural development. The higher council for Science and Technology. Amman. Jordan. 26 pp.

HCST, 1999. Integrated Studies of Azraq Basin for Optimum Utilization of the Natural Resources, Internal Report, HCST, Amman, Jordan.

Hellegers, P.J.G.J., Perry, J.N., Al-Aulaqi, N., Al-Eryani, A.R. and Al-Hebshi, M., 2008. Incentives to reduce groundwater extraction in Yemen. LEI Wageningen UR.

Hengl, T., de Jesus, J.M., MacMillan, R.A., Batjes, N.H., Heuvelink, G.B.M., Ribeiro, E., Samuel-Rosa, A., Kempen, B., Leenaars, J.G.B., Walsh, M.G. and Ruiperez, G.A., 2014. SoilGrids1km - Global Soil Information Based on Automated Mapping. PLoS ONE 9: e105992. DOI:10.1371/journal.pone.0105992.

Herbertson, P.W. and Tate, E.L., 2001. Tools for water use and demand management in South Africa. Secretariat of the World Meteorological Organization.

Hijmans, R.J., Cameron, S., Parra, J., Jones, P., and Jarvis, A., 2005. Very High Resolution Interpolated Climate Surfaces for Global Land Areas. International Journal of Climatology, 25, pp.1965-1978.

HKJ, 2009. Water for Life. Jordan's Water Strategy, 2008-2022. Hashemite Kingdom of Jordan HKJ, Amman.

Hobbler, M., Margane, A., AlMomani, M., and Subah, A., 2001. Groundwater Resources of Northern Jordan, contributions to the Hydrology of Northern Jordan Volume 4. Amman. BGR and water authority of Jordan.

Houdret, A., 2012. The water connection: irrigation and politics in southern Morocco. Water Alternatives, 5(2), pp.284-303.

Houdret, A. and Bonnet, S., 2013. Public-private partnerships in irrigation management: socioeconomic, political and environmental concerns. Presented at the ECPR general conference, Bordeaux, 2013. 
Howard Humphreys., 1982. Amman Water and sewerage Authority Azraq well field evaluation.

Hresha, H., 2013. The Importance of Azraq Reserve Wetland (in Arabic). RSCN report, Jordan.

http://www.arabgeographers.net/vb/threads/arab13825/

Huber, M., 2010. Development of a WEAP-Model for Azraq basin, Jordan, Part 1 - Hydrology. Amman: $\mathrm{MWI}$ and $\mathrm{GIZ}$.

Humpal, D., El-Naser, H., Irani, K., Sitton, J., Renshaw, K. and Gleitsmann, B., 2012. Review of Water Policies in Jordan and Recommendations for Strategic Priorities. USAID report, Jordan.

HWF, 2015. Action plan. Highland Water Forum Report for GIZ and MWI.

ICG, 2003. Red alert in Jordan: Recurrent unrest in Maan. Middle East Briefing N5 19 Feb 2003.

IGRAC, 2010. Global Groundwater Information System (GGIS). Delft, the Netherlands, IGRAC. www.igrac.net (Accessed 23 November 2010

Imache, A., Bouarfa, S., Hartani, T. and Kuper, M., 2010. La Mitidja 20 ans après. Réalités agricoles aux portes d'Alger, Alger: Editions Alpha.

Imache, A., 2014 personal communication, LISODE, Montpellier, France. From Closas, A. and Molle, F., 2016. Groundwater governance in the middle east and North Africa. IWMI Project report No. 1. USAID. $193 \mathrm{p}$.

İslamoğlu, H., 2000. Property as a contested domain: A reevaluation of the Ottoman Land Code of 1858. New perspectives on property and land in the Middle East, 39.

ISSP, 2014. Socio-Economic Analysis Report Impact Assessment of Groundwater Wells in Jordan. Institutional Support and Strengthening Program. USAID.

IUCN, 2007. National Dialogue for Azraq Water Basin, Agricultural Sector Report. 24 p.

Jasem, H. 2015. Studying the effects of using the effluent of Azraq refugee camp on groundwater resources in Azraq basin area. Groundwater Governance in the Arab World: Taking Stock and Addressing the Challenges, Research Update on Groundwater Policy, Management, Water Governance and Future Challenges in Azraq Basin, Jordan workshop.

Jarvis, A., Reuter, H.I., Nelson, A. and Guevara, E., 2008. Hole-filled SRTM for the Globe Version 4, Available from the CGIAR-CSI SRTM 90m Database (http://srtm.csi.cgiar.org).

Jaussen, A., 1948 [1907]. Coutumes des Arabes au pays de Moab. Paris: Adrien-Maisonneuve.

JHK, 2011. Jordan in figures, 2010.

JICA, 2007. The study for the water resources management and rural water supply improvement in the republic of Yemen, water resources management action plan for Sana'a basin, Earth System Science Co and Japan Techno, September 2007.

JMD, 2011. Annual report Jordan Metrology Department. Amman, Jordan.

Jones, J.R., 2012. Using gazelle dental cementum studies to explore seasonality and mobility patterns of the Early-Middle Epipalaeolithic Azraq Basin, Jordan. Quaternary International, 252, pp.195-201.

Jordan, 1952. Land and Water Settlement Law no 40, year 1952, and subsequent amendments. 
Jordannews, 2015. 15 water violation recorded and 616 illegal wells backfilled (in Arabic). Jordannews online newspaper. http://jordanews.com/Jordan/33991.html (accessed February 2017).

Joudeh, O. and Abu Taha, M., 1978. Present and needed information on Water Resources in Jordan. Proceedings of the National Water Symposium. National Resources Authority, Amman, 17 -59.

Kark, R. and Frantzman, S., 2012. Empire, state and the Bedouin of the Middle East, past and present: a comparative study of land and settlement policies. Middle Eastern Studies, 48(4), pp.487-510.

Kelly, A.B. and Peluso, N.L., 2015. Frontiers of commodification: state lands and their formalization, Society \& Natural Resources, 28(5), pp.473-495.

Khabrni, 2014. Names of illegal water users published (in Arabic). Khabrni online newspaper, 20 May 2014. www.khaberni.com (accessed February 2017).

Khair, S.M., Culas, R.J. and Hafeez, M., 2010, September. The causes of groundwater decline in upland Balochistan region of Pakistan: implication for water management policies. In Australian Conference of Economists (ACE10), Sydney, Australia.

Khater, A., 2002. Intensive groundwater use in the Middle East and North Africa. In: Llamas, M.R. and Custodio, E. (eds) Intensive Use of Groundwater: Challenges and Opportunities. A.A. Balkema, Lisse/Abingdon, Exton, Tokyo, pp.355-386.

Konikow, L.F. and Kendy, E., 2005. Groundwater depletion: A global problem. Hydrogeology Journal, 13(1), pp.317-320.

Kreb swiss., 1996. Jordan salt refinery goes on stream after modernization.

Laamari, A., Boughlala, M., Herzenni, A., Karrou, M. and Bahri, A., 2011. Water policies in MoroccoCurrent situation and future perspectives. Improving water and land productivities in rainfed systems. Community-Based Optimization of the Management of Scarce Water Resources in Agriculture in CWANA, (8), pp.103.

L'Economiste, 2016. Ressources hydriques agricoles - II faut assurer la résilience. 15/7/2016.

Lee, E.J. and Schwab, K.J., 2005. Deficiencies in drinking water distribution systems in developing countries. Journal of water and health, 3(2), pp.109-127.

Lemon, M., 1999. Exploring environmental change using an integrative method. Gordon and Breach Science Publishers, Amsterdam

Llamas, MR. and Martinez-Santos, P., 2005. Intensive groundwater use: silent revolution and potential source of social conflicts. Journal of Water Resources Plan Management, pp.131:337.

Louati, M.E.H. and Bucknall, J., 2009. Tunisia's experience in water resource mobilization and management. Water in the Arab World, pp.157.

Ma'an News, 2011. Royal court denies Jordan tribes targeting queen. Maan online newspaper. http://www.maannews.com/eng/ViewDetails.aspx?id=359160

Macoun, A and El Naser, H., 2000. Groundwater Resources Management in Jordan; Policy and Regulatory Issues, pp.105-115.

Madanat, H., 2010. Land tenure in Jordan. Land Tenure Journal, 1, pp.143-166. 
Mahdi, M., 2014. Devenir du foncier agricole au Maroc. Un cas d'accaparement des terres. New Med. N.4/2014.

Manseur, A., 2017. Pourquoi l'option des mégaprojets agricoles dans le sud de l'Algeria est néfaste. Online artilce. http://www.maghrebemergent.info/economie/algerie/70037-pourquoi-l-option-desmegaprojets-agricoles-dans-le-sud-de-l-algerie-est-nefaste-opinion.html/

MAPM, 2012. Place de l'eau dans le Plan Maroc Vert. Présentation Powerpoint

MAPM, 2007. Programme national d'économie d'eau en irrigation. Document principal. 10 Juillet 2007.

Margane, A., 2003. Management and Protection and Sustainable Use of Groundwater and Soil Resources in the Arab Region, Volume 4: Guideline for Groundwater Vulnerability Mapping and Risk Assessment for Susceptibility of Groundwater Resources to Contamination.

Margane, A., 2011. Review Comments on Saq-Ram Chapter. Personal Communication.

Margat, J. and van der Gun, J., 2013. Groundwater around the World: A Geographic Synopsis. CRC Press, USA

Massad, J., 2001. Colonial effects. The making of national identity in Jordan. Columbia: Columbia University Press, 396 pp.

Mbayden, A., 2013. Ministry of water demands 8 Million JD from ex-ministers who own wells (in Arabic). Shaabnews online newspaper. www.shaabnews.com/news-26097.htm (accessed February 2017).

McEvoy, D., Funfgeld, H. and Bosomworth, K., 2013. Resilience and climate change adaptation: the importance of framing. Planning Practice and Research Journal, 28 (3), pp.280-293.

Mesnil, A. and Habjoka, N., 2012. The Azraq dilemma, past, present and future groundwater management. German-Jordanian Programme "Management of Water Resources." Deutsche Gesellschaft für Internationale Zusammenarbeit (GIZ) GmbH, Amman, Jordan.

MetaMeta, 2015. Local groundwater management in Moghra aquifer opportunities, requirement, first steps. 68 pp.

MEWA, 1984. Water atlas of Saudi Arabia. Riyadh: Ministry of Agriculture and Water Saudi Arabian Printing Company Ltd.

MEWA, 2017. Number and Area of Agricultural Holdings with Land by Source of Irrigation in the Kingdom. Ministry of Water and Agriculture, Saudi Arabia Online data www.mewa.gov.sa.

MoA and FAO, 1963. Agricultural Census in Lebanon report 1960-1961. Ministry of Agriculture and Food and Agriculture Organization.

MoA, 2010. Annual Report. Ministry of Agriculture, Amman, Jordan.

MoA, 2012. Annual Report. Ministry of Agriculture, Amman, Jordan.

Moha, H., Fouad, E., Houria, A. and Redouane, C.A., 2017. Socio-Economics and Governance of Water Resources in the Souss-Massa River Basin. The Souss-Massa River Basin, Morocco, pp.335-349.

Molden, D., Sakthivadivel, R. and Samad, M., 2001. Accounting for changes in water use and the need for institutional adaptation. In Intersectoral management of river basins: Proceedings of an 
international workshop on "Integrated Water Management in Water-Stressed River Basins in Developing Countries: Strategies for Poverty Alleviation and Agricultural Growth," Loskop Dam, South Africa, 16-21 October 2000 (pp. 73-87).

Molle, F., 2008. Why enough is never enough: The societal determinants of river basin closure. International Journal of Water Resources Development, 24(2),pp.217-226.

Molle, F., Wester, P. and Hirsch, P., 2010. River basin closure: Processes, implications and responses. Agricultural Water Management, 97(4), pp.569-577.

Molle, F., 2017. Conflicting policies: agricultural intensification vs. water conservation in Morocco. GEAU Working Paper/Rapport de Recherche No.1. Montpellier, France.

Molle, F. and Closas, A., 2017. Groundwater governance: a synthesis. IWMI project report. USAID (vol. 6). $187 \mathrm{pp}$.

Molle, F. and Tanouti, O., 2017. Squaring the circle: Agricultural intensification vs. water conservation in Morocco. Agricultural Water Management, 192, pp.170-179.

Molle, F., Al Karablieh, E., Al Naber, M., Closas, A. and Salman, A., 2017a. Groundwater Governance in Jordan the Case of Azraq Basin, a Policy White Paper. Groundwater governance in the Arab World. IWMI project report. USAID.

Molle, F., Nassif, M., Jaber, B., Closas, A., and Baydoun, S., 2017b. Groundwater Governance in Lebanon; The Case of Central Beqaa, A policy white Paper. IWMI, USAID Project. 36 pp.

Molle, F., Closas, A., and Zubari, W., Forthcoming. Governing groundwater in the Middle East and North Africa Region. Chapter In: Advances in Groundwater Governance, edited by Villholth, K.; van der Gun, J.; Lopez-Gunn, E.; Conti, K. and Garrido, A. Balkema.

Morill, J. and Simas, J., 2009. Comparative analysis of water laws in MENA countries, in Jagannathan, N.V., Mohamed, A.S., and A. Kremer (eds.) Water in the Arab World: management perspectives and innovations, Washington DC: The World Bank, 285-334.

Mudallal, U., 1968. Water balance study in Azraq area. Groundwater Division, National Resources Authority, Amman.

Mukherji, A. and Shah, T., 2005. Groundwater socio-ecology and governance: a review of institutions and policies in selected countries. Hydrogeology Journal, 13(1), pp.328-345.

Müller, M.F., Müller-Itten, M.C. and Gorelick, S.M., 2017. How Jordan and Saudi Arabia are avoiding a tragedy of the commons over shared groundwater. Water Resources Research.

Mundy, M., 1994. Village land and individual title: Musha and the Ottoman land registration in the Ajlun district. In: Eugene, L. and Rogan, T. (Eds.), Village, Steppe and state. The social origins of modern Jordan. London and New York: British Academic Press, pp. 58-79.

Mundy, M., 1996. Qada' Ajlun in the late nineteenth century: Interpreting a region from the Ottoman land registers. Levant, 28, pp.77-95.

Mundy, M. and Saumarez Smith, R., 2007. Governing property, making the modern state law, administration and production in Ottoman Syria. London: I.B. Tauris.

MunlaHasan, A., 2007. Water use efficiency in Syrian agriculture. Damascus: Ministry of Agriculture and Agrarian Reform. NAPC National Agriculture Policy Center. 
MWI, 1998. Water Policy, Annual Report. Amman, Jordan

MWI, 2009. Annual Report. Ministry of Water and Irrigation, Amman, Jordan.

MWI, 2010. Water Budget of 2010. Amman: Directorate of Planning and Water Resources Studies of Water Resources Group.

MWI and WAJ, 2010. Annual report. Ministry of Water and Irrigation and Water Authority of Jordan. Amman, Jordan $85 \mathrm{pp}$.

MWI, 2011. Country Consultation with the Hashemite Kingdom of Jordan. Ministry of Water and Irrigation in Jordan, In Country Consultations for the Inventory of Shared Water Resources in Western Asia 2011-2012. Beirut and Amman.

MWI, 2013a. Annual Report. Ministry of Water and Irrigation, Amman, Jordan.

MWI, 2013b. Jordan Water Sector. Facts and figures. Report, Ministry of Water and Irrigation MWI, Amman, Jordan.

MWI, 2014. Annual report. MWI, Amman.

MWI, 2015a. Groundwater Management Policies. Ministry of Water and Irrigation (official website. www.mwi.gov.jo/sites/ar (accessed February 2017).

MWI, 2015b. Water Substitution Policy. Report, Ministry of Water and Irrigation, Amman, Jordan.

MWI, 2015c. National Water Strategy 2016 -2025. Ministry of Water and Irrigation, Amman.

MWRI, 2012. Strategy of water resources of Egypt till 2050. Ministry of Water Resources and Irrigation, Cairo, Egypt.

Nassif, M., 2016. Groundwater governance in the Central Bekaa, Lebanon. IWMI project Report No. 10. USAID. 129 pp.

Nelson, B., 1973. Azraq: desert oasis. London: Lane xx, 436p.. Illustrations, maps. Plants, pp.96-112.

NGWA, 2016. Facts about Global Groundwater Usage. The National Groundwater Association.

Nims, S., 2005. The dynamics of socio-environmental conflict of land reform in Jordan: A political ecology perspective. European University Institute Working Papers No. 23.

Noble, P.A.U.L., 1998. Quantification of recharge to the Azraq Basin. Arid Land Resources and their Management: Jordan's Desert Margin. London: Kegan Paul International, pp.103-9.

NWRA, 2009. Groundwater Management and Agricultural Development in Yemen. National Water Resources Authority

OECD, 2017. OECD Review of risk Management Policies Morocco, OCED Publishing, Paris. http://dx.doi.org/10.1787/9789264276482-en.

Ostrom, E., 1990. Governing the Commons: The Evolution of Institutions for Collective Action. Cambridge University Press, Cambridge.

Ostrom, E., 1990. Governing the Commons: The Evolution of Institutions for Collective Action. Cambridge: Cambridge University Press. 
Ostrom, E., 1992. Crafting Institutions for Self-Governing Irrigation Systems. San Francisco: Institute for Contemporary Studies

Ostrom, E., 2003. How types of goods and property rights jointly affect collective action. Journal of Theoretical Politics, 15 (3), pp.239-270.

Ouda, O.K., 2014. Impacts of agricultural policy on irrigation water demand: A case study of Saudi Arabia. International Journal of Water Resources Development, 30(2), pp.282-292.

Ouelhazi, H., Lachaal, F., Charef, A., Challouf, B., Chaieb, H. and Horriche, F.J., 2014. Hydrogeological investigation of groundwater artificial recharge by treated wastewater in semi-arid regions: Korba aquifer (Cap-Bon Tunisia). Arabian Journal of Geosciences, 7(10), pp.4407-4421.

Owen, R., 2000. New perspectives on property and land in the Middle East. Harvard University Press.

Oxford Business Group, 2012. Desert blooms : intitiatives to green the desert will boost agricultural production. Online artilce. https://www.oxfordbusinessgroup.com/analysis/desert-blooms-initiativesgreen-desert-will-boost-agricultural-production.

Palmer, C., 1999. Whose land is it anyway? An historical examination of land tenure and agriculture in northern Jordan. In: Gosden, C. and Hather, J. (Eds), The prehistory of food: Appetites for change. London: Routledge, pp.288-305.

Palmer-Jones, R., 1999. Slowdown in agricultural growth in Bangladesh: neither a good description nor a description good to give. Sonar Bangla, pp.92-136.

Patrick, E., 2002. Jordan. In: Rae, J. (Ed), An overview of land tenure in the Near East Region. Part i; Part ii, Individual country profiles, pp. 55-68.

Perry, C. and Steduto, P., 2017. Does improved irrigation technology save water. FAO: Cairo, Egypt, pp.36-39.

Petit, O., 2004. Groundwater overexploitation: Stakes and governance. Natures Sciences Societes, 12(2), pp.146-156.

Petranews, 2014. Cabinet discusses alternatives to closing illegal wells. Petra online newspaper. http://petra.gov.jo/Public

News/Nws_NewsDetails.aspx?Site_Id=2\&lang=1\&NewsID=131622\&CatID=13 (accessed February 2017).

Pinkerton, E., 1989. Cooperative Management of Local Fisheries (Vancouver. British Columbia: University of British Columbia.

PotatoPro, 2016. The Potato sector, algeria. Food Innovation Online Crop. Online article. https://www. potatopro.com/algeria/potato-statistics.

Prakash, A. and Ballabh, V., 2004. A win-some lose-all game! Social differentiation and politics of groundwater markets in North Gujarat, Institute of Rural Management Anand, Working Paper 183, pp.1-41.

Prime Minister's website, 2008. His Majesty establishes a Water Committee under the chairmanship of HRH Prince Faisal (in Arabic). www.pm.gov.jo/content/14470581395675 (accessed February 2017).

Quntar, A., 2005. Druze communities in Jordan. Online article http://www.druzeheritage.org/popups/1.pdf 
Rae, J., 2002. An overview of land tenure in the Near East Region. Part I.

Ragab, R., 2013. Water Governance in the Arab Region: Managing Scarcity and Securing the future.

Ramirez, O., Beck, R., Ghunaim, A. and Al-Tabini, R., 2008. Factors Affecting Agriculture Water Use in the Mafraq Basin of Jordan: Quantitative analyses and Policy Implications. Jordan Component of the Sustainable Development of Drylands Project. Report 7.

RAMSAR CONVENTION MONITORING PROCEDURE, 1990. Ramsar Advisory Mission No. 17: Azraq Oasis, Jordan

Razzaz, O., 1992. Contestation and mutual adjustment: The process of controlling land in Yajouz, Jordan. International Essay Competition on Parallel Legal Systems, Political and Policy Analysis. Indiana University, $50 \mathrm{pp}$.

Razzaz, O., 1993. Examining property and investment in informal settlements: The case of Jordan. Land Economics, 64(4), pp.341-355.

Reis, N., 2014. Coyotes, concessions and construction companies. Illegal water markets and legally constructed water scarcity in central Mexico. Water Alternatives, 7(3), pp.542-560.

RGPH, 2014. Recensement Ge'ne'ral de la Population et de l'Habitat 2014. Agadir, Morocco

Righi, E., Dogliotti, S., Stefanini, F.M. and Pacini, G.C., 2011. Capturing farm diversity at regional level to up-scale farm level impact assessment of sustainable development options. Agriculture Ecosystem Environment, 142, pp.63-74.

Rogers, P. and Hall, A., 2003. Effective Water Governance. GWP Technical Committee Background Paper No. 7, GWP, Stock-holm, Sweden.

Ronay, V., 1993. A salty oasis salt production in Azraq, Jordan. The world and school

Rosenberg, D. and Peralta., R., 2012. Economic impacts of groundwater drawdown in Jordan. Final report submitted to IRG Corporation for U. S. Agency for International Development.

RSCN, 1990. Azraq Wetland. 25 pp.

RSCN, 2013. The Royal Society for the Conservation of Nature Official Database.

RSCN, 2017. The Royal Society for the Conservation of Nature official website. www.rscn.gov.jo

Saadé-Sbeih, M., 2011. L'exploitation des eaux souterraines en Syrie centrale: construction de diagnostics et politiques d'intervention.

Saghir, J., 2004. "Reflections on Water Pricing and Tariff Design: Key Principles. Presentation to the Water Valuation Forum", in: IDRC (Ed.): Water Demand Management Forum -Middle East and North Africa: Advocating Alternatives to Supply Management of Water Resources. CD-ROM (Ottawa, Canada: IDRC).

Saidi, A., 2012 Première partie : état des lieux consolide, A.1.4 Elaboration du Plan de Gestion, «Diagnostic - Plan de gestion intégrée des ressources en eau dans le bassin hydrographique Cotier Algerois 02A», Ministère des Ressources en Eau, République Algérienne Démocratique et Populaire.

Sait, S. and Lim, H., 2006. Land law and Islam property and human rights in the Muslim World. UNHabitat. New York: Zed Books. 
Sait, M. and Tempra, O., 2015. Land fragmentation in Muslim communities: Traditional challenges and innovative consolidation approaches. Washington, DC. Annual World Bank Conference on Land and Poverty.

Salem, O., 1991. The Great Man-Made River Project: A partial solution to Libya's water supply. Planning for groundwater development in arid \& semi-arid regions. Proceedings of the International Roundtable Meeting, Cairo, 5-9 October 1991. Egypt.

Sarayanews, 2013. Major threats to the water sector due to groundwater over abstraction (in Arabic). Sarayanews online news-paper. $w$ ww. sarayanews.com/index.php?page=article\&id=219669 (accessed February 2017).

Sawaleif, 2013. Illegal usage of groundwater wells by influential people. Sawaleif online newspaper. http://www.sawaleif.com/.

Scates, M., 1966. Notes on the Hydrobiology of Azraq Oasis, Jordan. Sir John Cass College. pp.73-81.

Schlager, E., 2007. Community management of groundwater. In: The Agricultural Groundwater Revolution: Opportunities and Threats to Development, Giordano M, Villholth KG (eds). CABI Head Office: Oxford, UK: pp.131-152.

Schmidt, G., Subah, A. and Khalifa, N., 2004. Groundwater Flow Simulation and Groundwater Quantification. Contribution to the National Water Master Plan of Jordan. BGR and MWI.

Scott Wilson Kirkpatrick, 2002. Review and update of the three-dimensional flow model of the regional Disi-Ram aquifer and borehole design for the Dubaydib wellfield. Unpublished report, Ministry of Water and Irrigation, Amman.

Shah, T., 1993. Water Markets and Irrigation Development: Political Economy and Practical Policy. Bombay, India: Oxford University Press

Shah, T., Burke, J. and Villholth, K., 2007. Groundwater: a global assessment of scale and significance. groundwater boom and bust?. Water for Food Water for Life, 10, pp.395-432.

Shah T. 2009. Taming the Anarchy. Resource for the Future Press: Washington, DC.

Shahbaz, M. and Sunna, B., 2000. Integrated studies of Azraq Basin in Jordan. USDA Forest Service, 13, pp.149- 157 .

Shawaqfah, M., Alqdah, I. and Nusier, O.K., 2015. Water resources management using modeling tools in desert regions: the Azraq Basin, Jordan. International Journal of Modeling and Optimization, 5(1), pp.55.

Shehadeh, R., 1982. The land law of Palestine: An analysis of the definition of state lands. Journal of Palestine Studies, 11, pp.82-99.

Siebert, S., Burke, J., Faurès, J.-M., Frenken, K., Hoogeveen, J., Döll, P. and Portmann, F.T., 2010. Groundwater use for irrigation - a global inventory. Hydrology Earth System Science, 14, pp.18631880.

Sims, D., 2015. Egypt's Desert Dreams: Development Or Disaster?. Oxford University Press.

Stack, L., 2007. Egypt working to reclaim the desert, remote areas grow crops, but some say they are ignored. online artilce. SFGate. http://www.sfgate.com/green/article/Egypt-working-to-reclaim-thedesert-3234720.php. 
Stephan, R.M., 2007. Legal Framework of Groundwater Management in the Middle East (Israel, Jordan, Lebanon, Syria and the Palestinian Territories). In Water Resources in the Middle East (pp. 293-299). Springer Berlin Heidelberg.

Stevenson, G.G., 2005. Common property economics: A general theory and land use applications. Cambridge University Press.

Stoorvogel, J.J., Bakkenes, M., Temme, A.J.A.M., Batjes, N.H., ten Brink, B.J.E., 2017. S-world: a global soil map for environmental modelling. Land Degradation \& Development, 28, pp.22-33. https://doi.org/10.1002/

Sørensen, R., Zinko, U., Seibert, J., 2006. On the calculation of the topographic wetness index: evaluation of different methods based on field observations. Hydrology and Earth System Sciences, 10, pp.101-112.

Strakes, E., 2011. Arab and non-Arab as state-like entities: Informal alliances and conflict patterns in the historic and contemporary Middle East. The Journal of the Middle East and Africa, 2 (2), pp.235 253.

Subeh, A., 2006. Water in Jordan: water security and protection. Presentation at the 'Water security and protection work-shop', June, 2006.

Taher, T., Bruns, B., Bamaga, O., Al-Weshali, A. and van Steenbergen, F., 2012. Local groundwater governance in Yemen: building on traditions and enabling communities to craft new rules. Hydrogeology Journal, 20(6), pp.1177-1188.

Tarawneh, M., 1999. Public land between the state and tribes: a dilemma of rural development. CIHAM: Options Méditerranéennes, 38, pp.345-352.

Taylor, G.C., 1976. Historical review of the international water-resources program of the US Geological Survey, 1940-70 (No. 911). US Govt. Print. Off.,.

The North Africa Post, 2013. Algeria: Sahara desert agriculture a success. Online newspaper. http://northafricapost.com/4304-algeria-sahara-desert-agriculture-a-success.html

TJT, 2011. Gov't pledges to settle tribal-state land disputes. The Jordan Times Newspaper.

TJT, 2012. Al Yasin family never received state-owned land. The Jordan Times Newspaper.

UNDP, 1966. General Report on the Ground-water Investigation of the Azraq Basin. UN.

UNDP, 2013a. Water Governance in the Arab Region: Managing Scarcity and Securing the Future. UNDP, New York, USA.

UNDP, 2013b. Food and Nutrition Security in Jordan towards Poverty Allevia-tion. UNDP Project report, Amman, Jordan.

UNDP, 2014. Groundwater Assessment and Database Project, Final Output. May 2014.

UNESCO, 2014. Opportunities to managed aquifer recharge. Second learning Workshop for MENARID Project Managers. December, 2012. Final report UNESCO Series on Groundwater for MENARID. 44pp.

UN-ESCWA and BGR, 2013. Inventory of Shared Water Resources in Western Asia, Beirut: UN-ESCWA (United Nations Economic and Social Commission for Western Asia), BGC (Bundesanstalt für Geowissenschaften und Rohstoffe). 
Uppala, S.M., Kållberg, P.W., Simmons, A.J., Andrae, U., Bechtold, V.D., Fiorino, M., Gibson, J.K., Haseler, J., Hernandez, A., Kelly, G.A. and Li, X, 2005. The ERA-40 re-analysis. Quarterly Journal of the royal meteorological society, 131(612), pp.2961-3012.

USAID, 2011. Instituting water demand management in Jordan (IDARA) evaluation. Final report.

USAID, 2014. Socio-Economic Analysis Report Impact Assessment of Groundwater Wells in Jordan. Institutional Support and Strengthening Program. USAID, Amman, Jordan.

van Steenbergen, F., and El Naouari, N., 2010. The blind spot in water governance: conjunctive groundwater use in MENA countries, in Bogdanovich S., and Salame, L. (eds.). Water policy and law in the Mediterranean: an evolving nexus, Serbia: Faculity of Law Business Academy Novi Sad, pp.171 189.

van Steenbergen, F. and El Haouari, N., 2011. The blind spot in water governance: conjunctive groundwater use in the MENA countries. Water policy and law in the Mediterranean: an evolving nexus. UNESCO, Paris.

van Steenbergen, F., Kumsa, A., and Al-Awlaki, N., 2015. Understanding political will in groundwater management: comparing Yemen and Ethiopia. Water Alternatives, 8(1), pp.774-799.

Venot, J., and Molle, F., 2007. Irrigate Agriculture, Water Pricing and Water Savings in the Lower Jordan River Basin (in Jordan). Research Report 18. Comprehensive Assessment of Water Management on Agriculture. IWMI, Colombo.

Venot, J.P., Molle, F. and Hassan, Y., 2007a. 10 Wells and Canals in Jordan: Can Pricing Policies Regulate Irrigation Water Use? Irrigation Water Pricing: the Gap between Theory and Practice, 4, pp.233.

Venot, J.P., Molle, F. and Hassan, Y., 2007b. Irrigated agriculture, water pricing and water savings in the Lower Jordan River Basin (in Jordan). Comprehensive Assessment of Water Management in Agriculture Research Report, 18, pp.66.

Venot, J. and Molle, F., 2008. Groundwater depletion in the Jordan Highlands: Can pricing policies regulate irrigation water use?. Water Resources Management, 22(12), pp.1925-1941.

Voss, K., Famiglietti, J., Lo, M., Linage, C., Rodell, M. and Swenson, S., 2013. Groundwater depletion in the Middle East from GRACE with implications for transboundary water management in the TigrisEuphrates-Western Iran region. Water Resources Journal, 49(2), pp.904-914. doi: 10.1002/wrcr.20078.

Vrba, J. and van der Gun, J., 2004. The world's groundwater resources. World Water Development Report 2, Contribution to Chapter 4, Report IP 2004-1, System, 2, pp.1-10.

Wade, R., 1987. Village Republics. Cambridge: Cambridge University Press

Wada, Y., van Beek, L. P. H. and Bierkens, M. F. P., 2012. Non-sustainable groundwater sustaining irrigation: a global assessment. Water Resources Research, 48, WOOLO6. doi:10.1029/2011WR010562.

Wahlin, L., 1994. How long has land been privately held in northern al-Balqa Jordan?. Geografiska Annaler, 76b (I), pp.3-19.

WAJ, 2010. Annual report. WAJ, Ministry of Irrigation and Agriculture, Amman, Jordan. 
Wang, J., Huang, J., Huang, Q. and Rozelle, S., 2006. Privatization of tube wells in North China: determinants and impacts on irrigated area, productivity and the water table. Hydrogeology Journal, 14(3), pp.275-285.

WaterWatch, 2008. Water balance and evaluation of water saving investments in Tunisian agriculture.

Weir, C., 2013. From Diwan to Palace: Jordanian Tribal Politics and Elections. PhD thesis. US: Case Western Reserve University.

White, E. and Kromm, E., 1995. Local Groundwater Management Effectiveness in the Colorado and Kansas Ogallala Region. Natural Resources Journal, 35, pp.275-307.

World Bank, 2001. Egypt: Toward Agricultural Competitiveness in the $21^{\text {st }}$ Century, an Agricultural Export-Oriented Strategy. "Report No. 23405, World Bank, Washington, DC.

World Bank, 2003. Republic of Lebanon: policy note on irrigation sector sustainability, Report No.28766-LE, Agriculture and Rural Development Department, Washington DC: The World Bank.

World Bank, 2007. Making the most of scarcity: accountability for better water management in the Middle East and North Africa, Washington DC: The World Bank

WWDR, 2015. Water for a sustainable World Facts and figures. UNESCO 2015. 12 pp.

Zecchini, L., 2011. Bedouin tribes accuse Jordan's Queen Rania of corruption. www.theguardian.com/world/2011/feb/15/bedouin-accuse-jordan-queen-corruption

Zeitoun, M., Allan, T., Al Aulaqi, N., Jabarin, A. and Laamrani, H., 2011. Water demand management in Yemen and Jordan: addressing power and interest. The Geographical Journal, 178(1), pp.54-66.

Zekri, S., 2008. Using economic incentives and regulations to reduce seawater intrusion in the Batinah coastal area of Oman. Agricultural Water Management, 95(3), pp.243-252.

Zhou, Y., Dong, D., Liu, J. and Li, W., 2013. Upgrading a regional groundwater level monitoring network for Beijing Plain, China. Geoscience Frontiers, 4(1), pp.127-138.

Zubari, W.K. and Lori, I.J., 2006. Management and sustainability of groundwater resources in Bahrain. Water policy, 8(2), pp.127-145. 


\section{Funding}

This thesis was performed in the framework of the Agricultural Transformation by Innovation (AGTRAIN; www.agtrain.eu) Erasmus Mundus Joint Doctorate Program, funded by the EACEA (Education, Audiovisual and Culture Executive Agency) of the European Commission. 